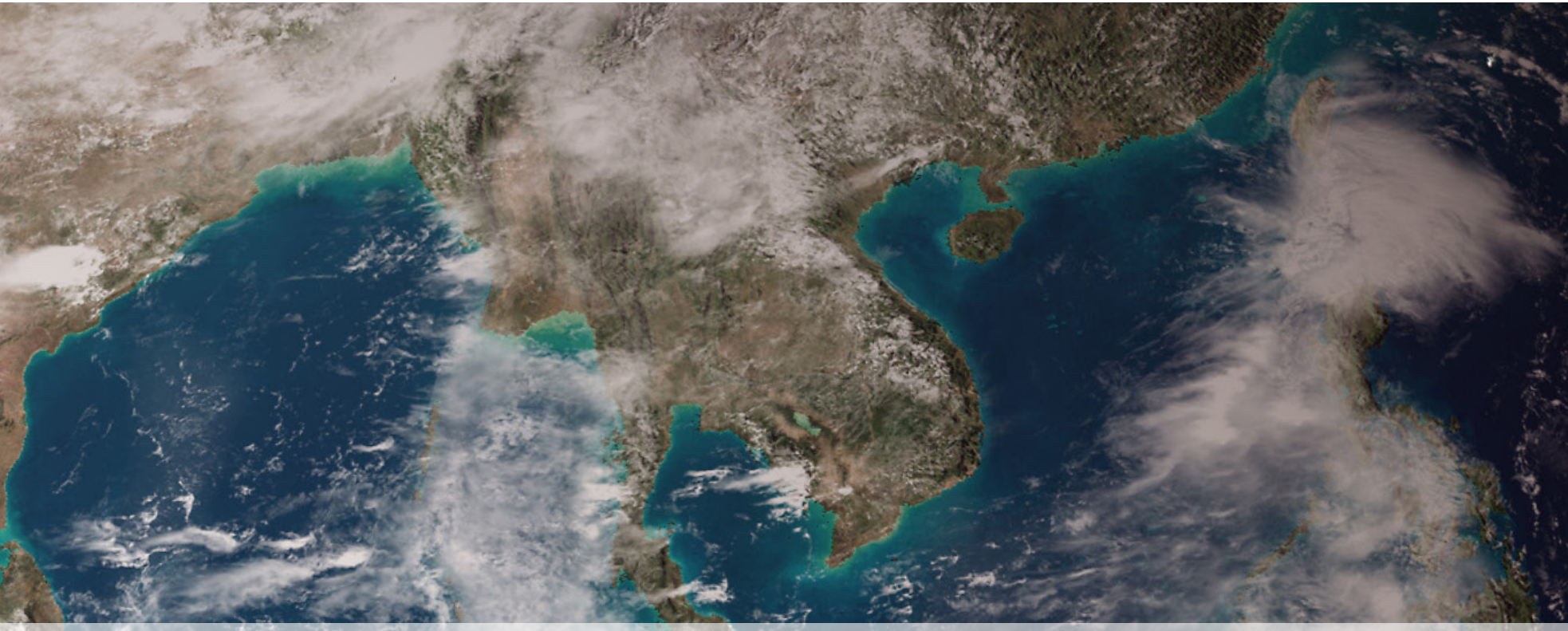

\title{
Contracartografias: Práticas críticas em um mundo hipermapeado
}

São Carlos - 2018

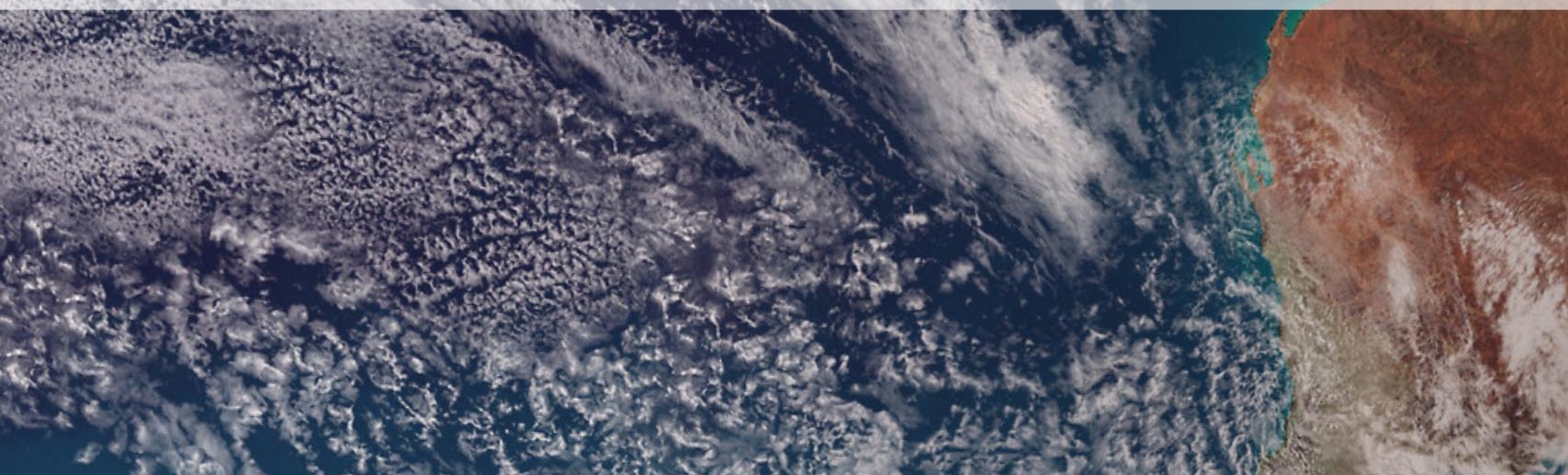




CRISTINA AKEMI GOLDSCHMIDT KIMINAMI

Contracartografias: Práticas críticas em um mundo hipermapeado

\author{
Versão corrigida
}

Dissertação entregue ao Instituto de Arquitetura e Urbanismo da Universidade de São Paulo (IAU-USP), como parte dos requisitos para obtenção do título de mestre em Arquitetura e Urbanismo.

Área de concentração: Teoria e História

Orientador: Prof. Dr. David Moreno Sperling

São Carlos

2018 


\section{AUTORIZO A REPRODUCAO TOTAL OU PARCIAL DESTE TRABALHO, POR QUALQUER MEIO CONVENCIONAL OU ELETRONICO, PARA FINS DE ESTUDO E PESQUISA, DESDE QUE CITADA A FONTE}

Ficha catalográfica elaborada pela Biblioteca do Instituto de Arquitetura e Urbanismo com os dados fornecidos pelo(a) autor(a)

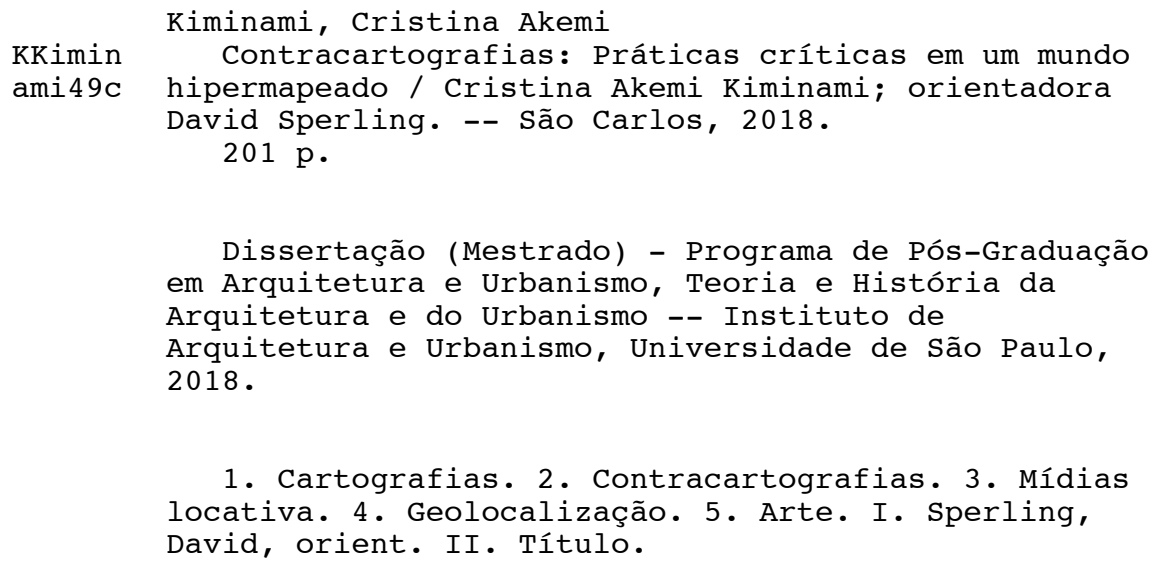

1. Cartografias. 2. Contracartografias. 3. Mídias locativa. 4. Geolocalização. 5. Arte. I. Sperling, David, orient. II. Título.

Bibliotecária responsável pela estrutura de catalogação da publicação de acordo com a AACR2: Brianda de Oliveira Ordonho Sígolo - CRB - 8/8229 


\section{FOLHA DE JULGAMENTO}

\section{Candidato(a): Cristina Akemi Goldschmidt Kiminami}

Título da dissertação: “Contracartografias: Práticas críticas em um mundo hipermapeado".

Data da defesa: 08/06/2018

Orientador: Prof. Dr. David Moreno Sperling

\section{Comissão Julgadora:}

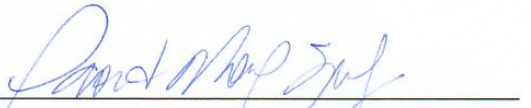

Prof. Dr. David Moreno Sperling (IAU/USP)

\section{G M L h}

Prof. Dr. Ruy Sardinha Lopes (IAU/USP)

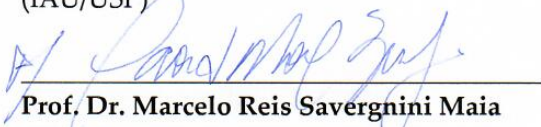
(EA/UFMG)

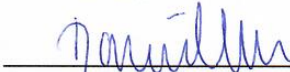

Profa. Dra. Daniela Kutschat Hanns (FAU/USP)

\section{Resultado:}

Não votante

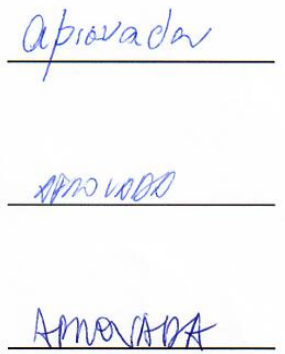

Coordenadora e Presidente da Comissão de Pós-Graduação do Programa de PósGraduação em Arquitetura e Urbanismo: Prof. Dr. Tomás Antonio Moreira. 


\section{AGRADECIMENTOS}

Meu profundo agradecimento,

Ao professor David Sperling, pela orientação dedicada e presente; pela paciência e suporte durante toda minha trajetória do mestrado.

Aos professores Ruy Sardinha e Daniela Kutschat Hanns pelas valiosas contribuições no exame de qualificação.

Aos professores do Núcleo de Pesquisa em Espacialidades Contemporâneas (NEC) que através do convívio acadêmico, enriqueceram a minha experiência na área de pesquisa.

À CAPES, pelo apoio financeiro para o desenvolvimento da pesquisa.

Aos professores das disciplinas cursadas no IAU, Anja Pratschke, Paulo Cesar Castral, Simone Helena Tanoue Vizioli, Joubert José Lancha, Manoel Rodrigues Alves, Fábio Lopes de Souza Santos, Ruy Sardinha, Eulália Negrelos, Tomás Moreira e Bruno Daminieli agradeço pelas discussões e reflexões, que me permitiram um intenso aprendizado ao longo do programa de pós-graduacão.

Aos professores Fábio Lopes de Souza Santos e David Sperling, por compartilharem suas experiências didáticas durante o estágio PAE.

Aos funcionários da pós-graduação do IAU-USP, por toda atenção e dedicação.

Aos colegas pós-graduandos do Núcleo de Pesquisa em Espacialidades Contemporânea s (NEC) e de outros grupos e espaços, pela rica convivência. Em especial, Daniela Hladkyi, Amanda Bianco Mitre, Fernanda Gomes, Tássia Vasconselos, Guilherme Cuoghi, Paula Pacheco.

À Marília Solfa, Roberta Sakai, Lívia de Morais, Mateus Rosada, Camila Sant'anna, Daniel Paschoalin, Maria Claudia Magon, Luciana Monteiro Lindo, Sandra Frederici, que incentivaram e acreditaram na minha decisão de retorno à academia e pelo companheirismo durante todo o processo.

Aos meus irmãos, Daniel Kiminami e Carolina Kiminami, pelo companheirismo, amizade e cumplicidade.

Aos meus pais, Claudio Kiminami e Ruth Kiminami, que tiveram um papel fundamental nesta e em todas as conquistas que alcancei, e sempre, com muito amor, me permitiram traçar o meu próprio caminho.

Aos Amigos, que sempre presentes no meu coração, me relembraram sempre uma perspectiva mais ampliada que é possível ter da VIDA. 
"I imagine that a fish out of water is the only fish that has an inkling of water" J. R. R. Tolkien 

KIMINAMI, C.A.G. Contracartografias: Práticas críticas em um mundo hipermapeado. São Carlos: 2018. Dissertacão (Mestrado), São Paulo: Programa de Pós-Graduação em Arquitetura e Urbanismo do Instituto de Arquitetura e Urbanismo da Universidade de São Paulo (IAUUSP), 2018.

\section{Resumo}

Esta dissertação foca práticas contracartográficas realizadas por ativistas e artistas com o uso de mídias locativas. Observar estas práticas, que apontam no sentido inverso das cartografias hegemônicas e dominantes, permite uma visualização crítica de tensionamentos do atual contexto hipermediado. Conjuntamente, este tipo de estudo, permite apontar aspectos de visibilidade e invisibilidade que operam nesses meios informacionais e como são desafiados e tensionados com lentes críticas. Para tanto, alguns tópicos históricos da representação locativa são desenvolvidos, assim como são discutidos alguns elementos do contexto atual de profusão do uso de mapas georreferenciados em aplicativos móveis. A dissertação busca explicitar, a partir dos casos escolhidos, que as tecnologias locativas devem ser vistas e operadas criticamente, num contexto em que vêm sendo naturalizadas e incorporadas massivamente no cotidiano.

Palavras-chave: Cartografias; Contracartografias, Mídias locativas, geolocalização; Arte; Ativismo 

KIMINAMI, C.A.G. Countercartographies: Critical practices in a hyper-mapped world.

São Carlos: 2018. Dissertation (Master-degree), Institute of Architecture and Urbanism, University of São Paulo, (IAUUSP), 2018.

\begin{abstract}
This dissertation focuses on countercartographic practices performed by activists and artists with the use of locative media. Observing these practices, which point in the opposite direction of the dominant cartographies, allows a critical visualization of tensions of the current hypermediated context. Together, this type of study allows us to point out aspects of visibility and invisibility that operate in these informational media and how they are challenged and stressed with critical lenses. To do so, some historical topics of locative representation are developed, as are some elements of the current context of profusion of the use of georeferenced maps in mobile applications. The dissertation seeks to explain, from the chosen cases, that locative technologies must be seen and operated critically, in a context in which they have been naturalized and massively incorporated in daily life.
\end{abstract}

Keywords: Cartographies; Countercartographies; Locative media; geolocation; Art; Activist 
Imagem Capa: Representação composta do Hemisfério Oriental da Terra, com base nos dados do Terra MODIS, Aqua MODIS, Programa de Satélites Meteorológicos de Defesa, ônibus espacial Endeavour e Projeto de Mapeamento Antártica Radarsat, combinados por cientistas e artistas. Data: Out.2007. Fonte: Wikimedia/NASA. 


\section{ÍNDICE}

Lista de Siglas 15

Lista de Figuras 16

INTRODUÇÃo 21

Recorte e contextualização 22

Aspectos metodólogicos 24

Estrutura da dissertação 26

Termos relevantes 30

\section{CAPÍTULO 1. LINHAS CARTOGRÁFICAS 37}

1.1- Precedências históricas sobre a representação de localizações 38

1.2- A esfera hiper-mapeada 60

1.3- Desconstruindo a neutralidade dos mapas 70

CAPÍTULO 2. MUNDOS (CONTRA)CARTOGRAFADOS 85

2.1- A pervasividade dos mapas colaborativos 86

2.2- Contracartografias Ativistas 111

CAPÍTULO 3. PRÁTICAS CONTRACARTOGRÁFICAS NA ARTE 127

3.1- Das deambulações aos percursos georreferenciados 129

3.2- Quatro projetos de contracartografias 137

3.2.1- Meridians (2005) - Jeremy Wood 138

3.2.2- Monochrome Landscapes (2004) - Laura Kurgan 149

3.2.3 - Projeto correspondência (2013) - Manuela Costalima 165

3.2.4- Canal Motoboy (2007-2015) - Antoni Abad 172

3.2.5- Os quatro projetos, entre os mapas e as trajetórias 179

CONSIDERAÇÕES FINAIS 187

BIBLIOGRAFIA 193 


\section{LISTA DE SIGLAS}

AAG - American Association of Geographers

ANILCA - Alaska National Interest Lands Conservation Act

ANWR - Artic National Wildlife Refuge

API - Application programming interface

CET - Companhia de Engenharia de Tráfego

CIA - Central Intelligence Agency

EUA Estados Unidos da América

FAU - Faculdade de Arquitetura e Urbanismo

GIS - Geographic Information System/ Geographic Information Science

GPS - Global Positioning System

GRS80 - Geodetic Reference System 1980

GTM - Greenwich Mean Time

MASP - Museu de Arte de São Paulo

NEC - Núcleo de Pesquisa em Especialidades Contemporâneas

OSM - Open Street Map

OSMF - Open Street Map foundation

ONG - Organização Não-Governamental

PAE - Programa de aperfeiçoamento de Ensino

PNT - Positioning Navigation and Timing

USP - Universidade de São Paulo

VGI - Volunteered geographic information

WGS84 - World Geodetic System 1984 


\section{LISTA DE FIGURAS}

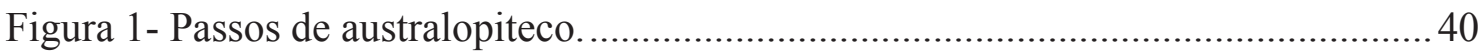

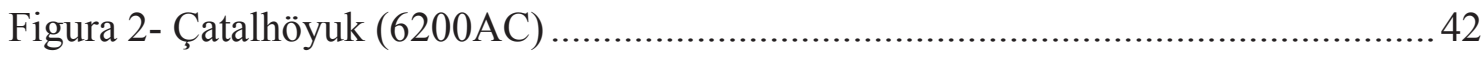

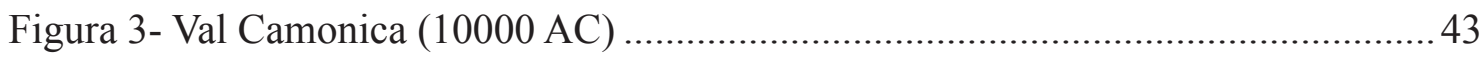

Figura 4- Mapa feito a partir dos textos deixados por Strabo...................................... 46

Figura 5- Mapa feito a partir dos textos deixado por C.Ptolomeu................................. 47

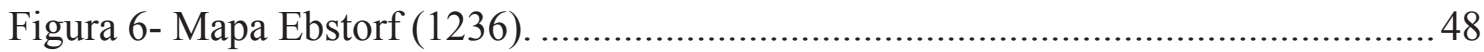

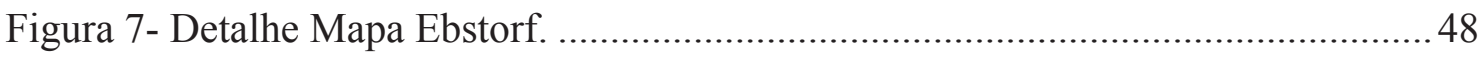

Figura 8- Mapa do Mundo (Carta Marina) por Francesco Rosseli (1508). .................... 53

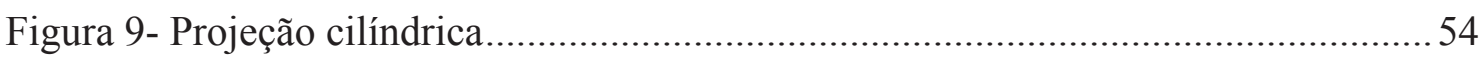

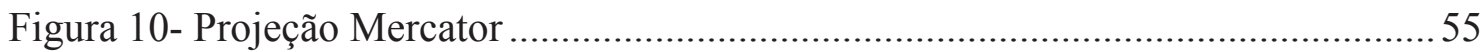

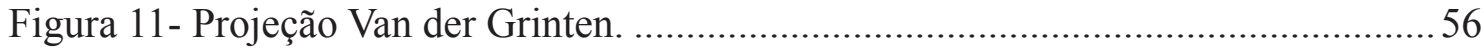

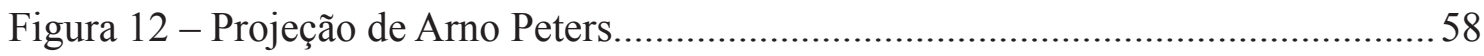

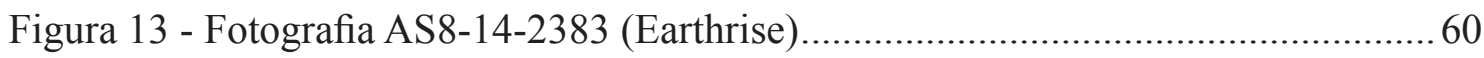

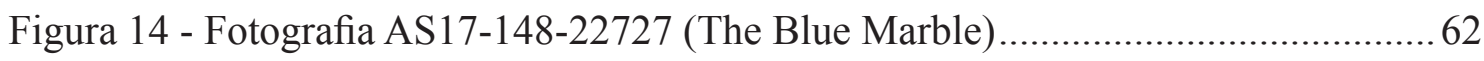

Figura 15 - 'The Blue Marble: The Next Generation “ “.................................................. 64

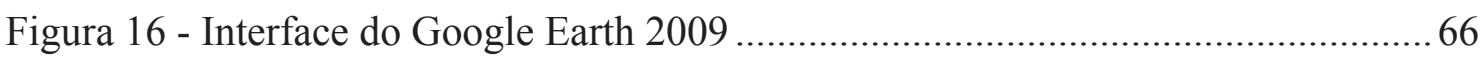

Figura 17 - Ilustração do artigo Ce n'est pas le monde ................................................. 77

Figura 18 - Diagrama dos teóricos da Cartografia Pós-Representacional ...................... 81

Figura 19- Interfaces do aplicativo Waze..................................................................... 93

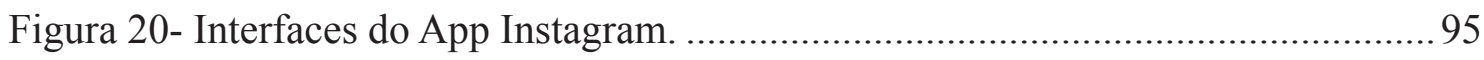

Figura 21 - On Broadway- Interface interativa dos dados........................................... 96

Figura 22- On Broadway- Interface interativa dos dados ........................................... 97

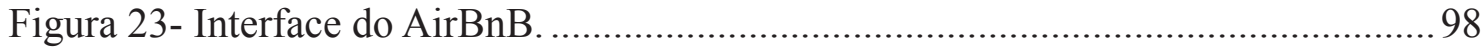

Figura 24- Imagem referente a 8 de Junho de 2009 em Amsterdã ................................ 99

Figura 25- Imagem referente a 21 de abril de 2017 em Amsterdã................................ 100

Figura 26- Interface do mapa de calor divulgada pelo App Strava............................... 102

Figura 27- Marcação em uma base militar no Afeganistão. ........................................ 103

Figura 27- Marcação em uma base militar no Nigéria. ................................................ 103

Figura 29-Selfie tirada por um soldado americano .................................................. 104 


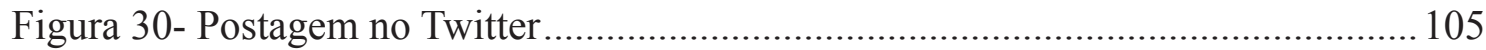

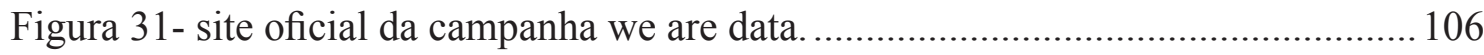

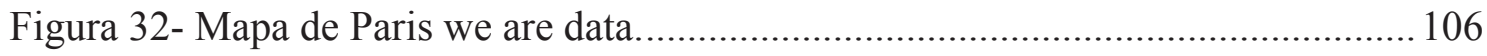

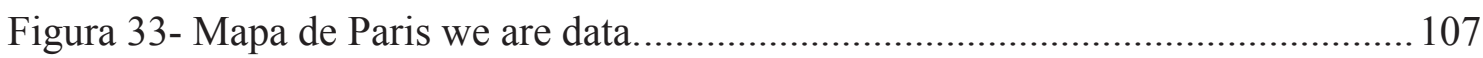

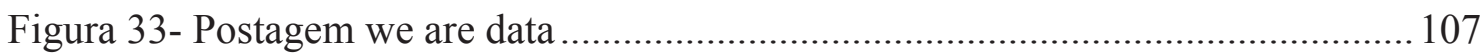

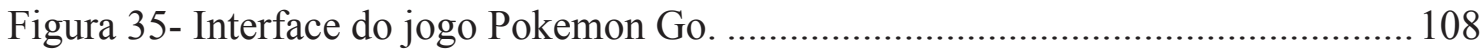

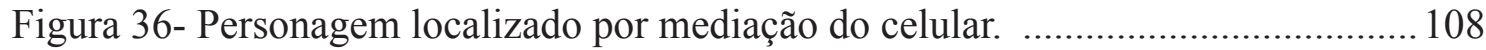

Figura 37- Aglomerados de usuários do jogo Pokemon Go ........................................... 109

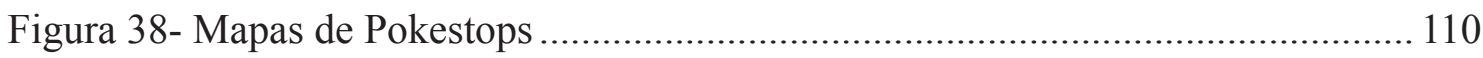

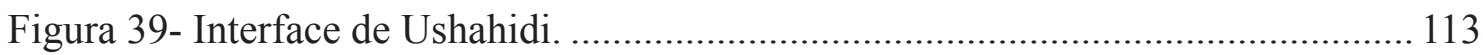

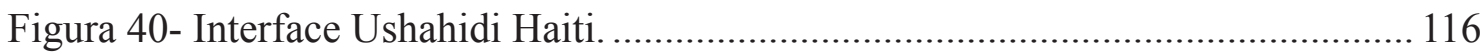

Figura 41- Interface do aplicativo Arriving in Berlin.................................................. 117

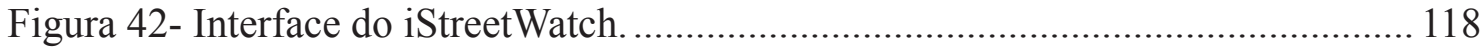

Figura 43- Interface do aplicativo Nós por Nós....................................................... 120

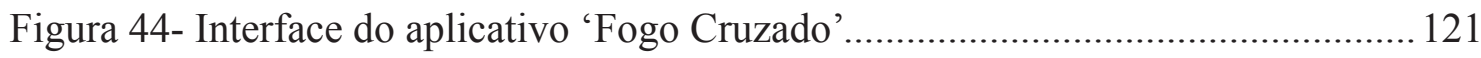

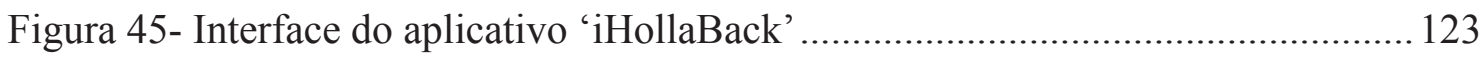

Figura 46- Interface do aplicativo 'Chega de FiuFiu'................................................... 123

Figura 47- Interface do aplicativo 'Onde Fui Roubado' ................................................. 124

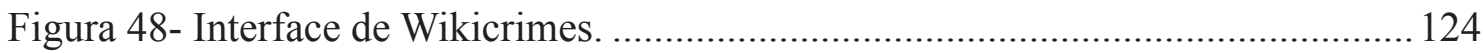

Figura 49- A Line Made by Walking -Richard Long .................................................. 132

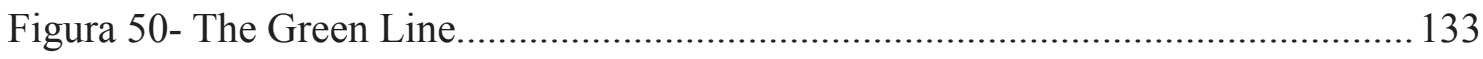

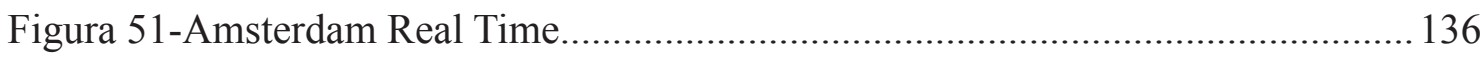

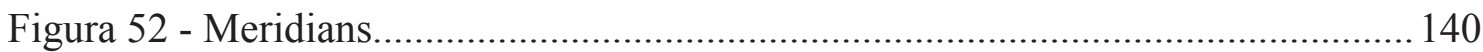

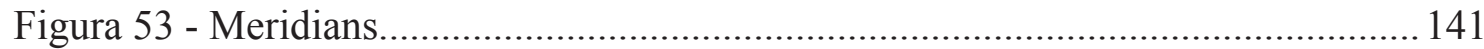

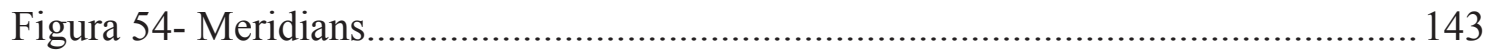

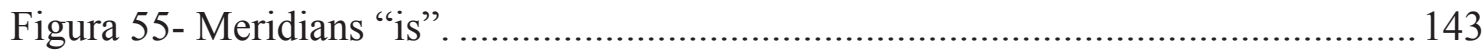

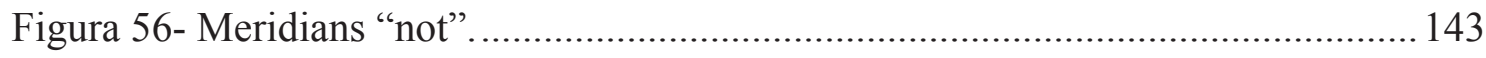

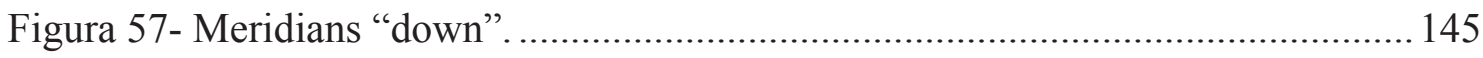

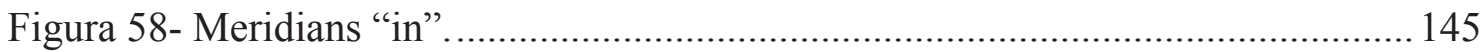

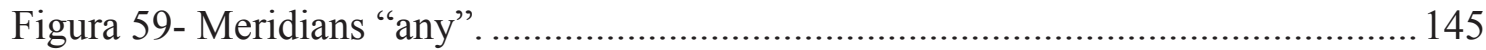

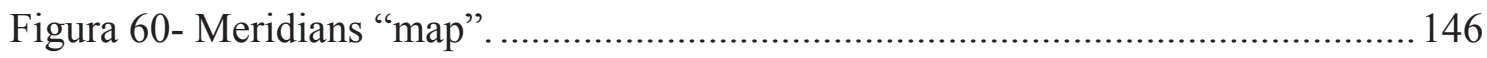




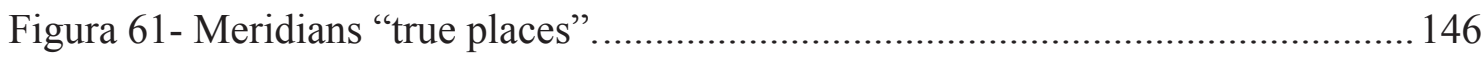

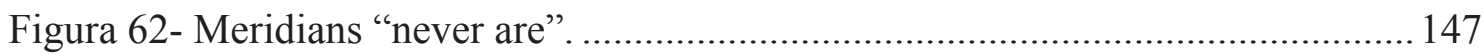

Figura 63- 'Four Panels' ...................................................................................... 150

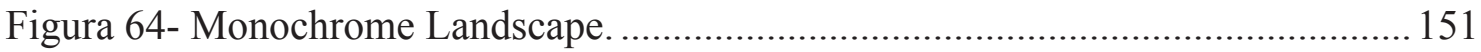

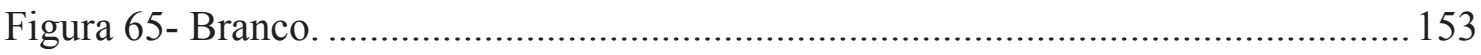

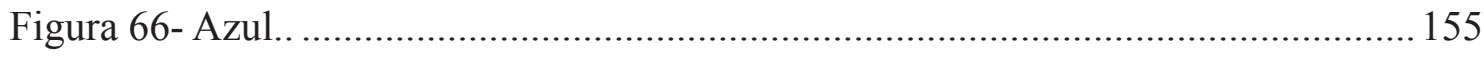

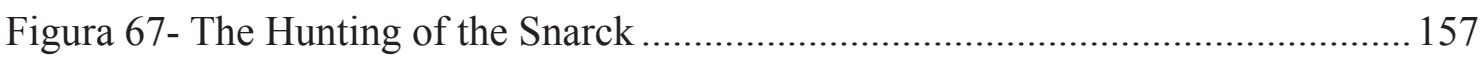

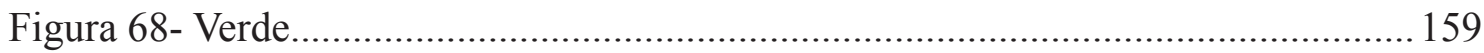

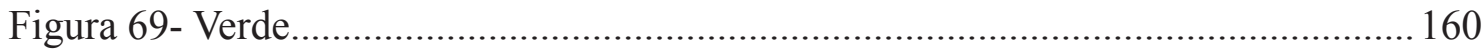

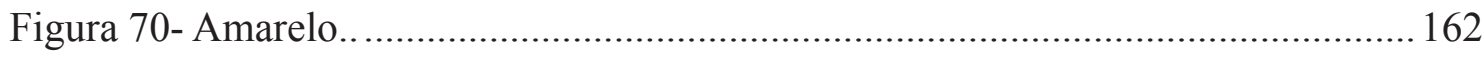

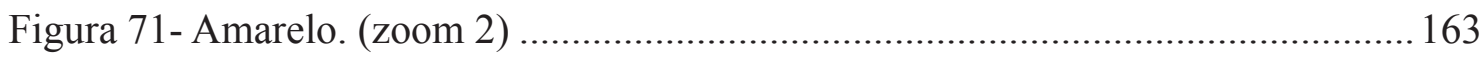

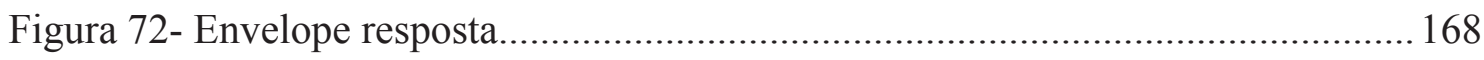

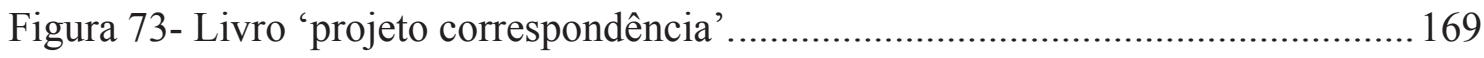

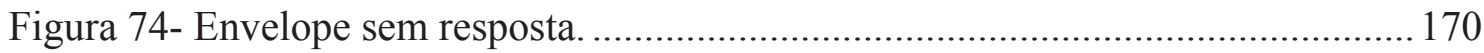

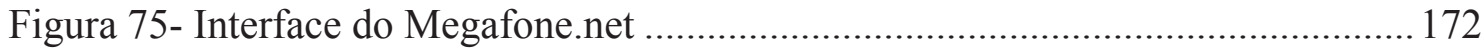

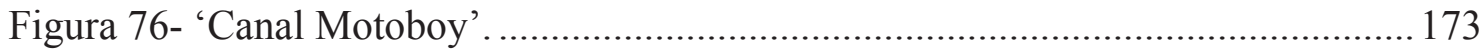

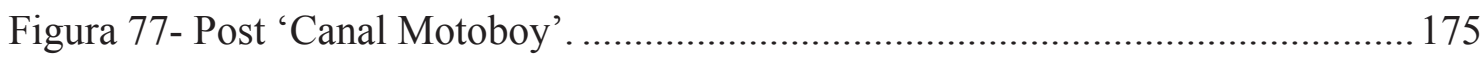

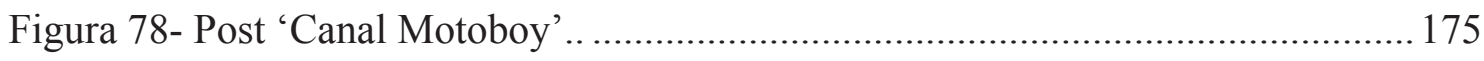

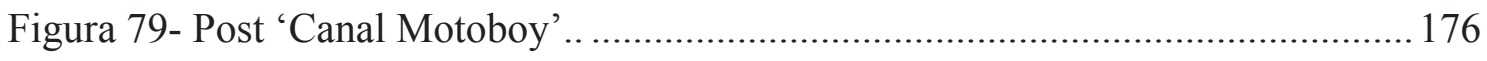

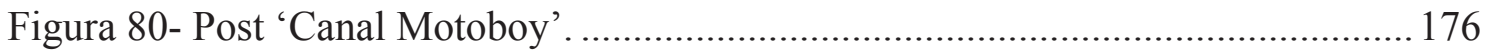

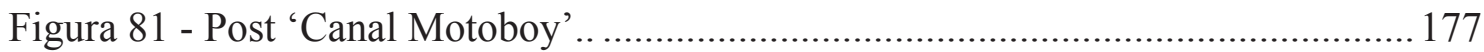

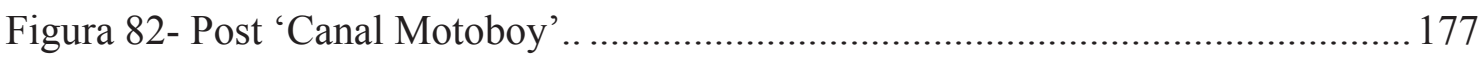

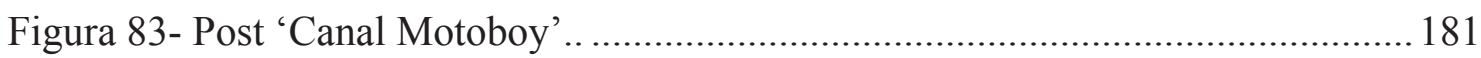




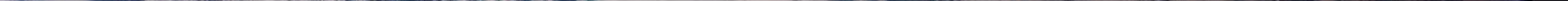




\section{Introdução}




\section{RECORTE E CONTEXTUALIZAÇÃO}

Localizar-se e obter informações sobre como chegar a um outro ponto nunca foi tão rápido, bastam poucos cliques e pronto. O mundo hiperconectado gera uma saturação intensa de informações, as quais são disponibilizadas pelas mais diversas redes. As informações que outrora precisavam de materialidade para serem transmitidas, hoje são disponíveis por meio de ondas que são decodificadas através da mediação tecnológica.

Foi notando esse contexto que surgiu a indagação sobre o universo das informações locativas atuais e o que elas são capazes de revelar sobre aspectos significativos da contemporaneidade. Afinal, a forma de como se representam essas informações está diretamente ligada à maneira de se localizar, não só geograficamente, mas social e economicamente.

Portanto, a pesquisa partiu do interesse em entender como que, num contexto saturado de informações e hipermediado por tecnologias locativas, o homem tem construído seu senso de localização. E ainda como, neste mesmo contexto de grande profusão de mapas digitais e dados georreferenciados, operam alguns aspectos de visibilidade e invisibilidade informacionais; E como esses aspectos têm sido tensionados criticamente.

A necessidade de localizar-se (em termos cognitivos e espaciais), saber onde se está e para onde se pode ir é uma indagação natural do ser humano; buscar a relação com o meio que o cerca é fundamental para garantir uma sensação de estar situado e de ocupar um lugar no mundo. Historicamente, a relação entre homem e espaço sofre sensíveis transformações. É nesse processo de entendimento sobre seu entorno e sua localização que passam a surgir as mais criativas maneiras de registros e representações, sejam fonéticos, gráficos, artísticos para atualizar esse senso e permitir que essa movimentação continue. Localizar e sistematizar são características essenciais para qualquer mapeamento, seja de um complexo de informações abstratas, seja de uma situação empírica no mundo. E, sempre que se sistematizam dados e informações, há uma leitura a ser transmitida ou revelada.

As cartografias, um dos temas chave desta pesquisa, já tomaram a forma de registros como os mencionados, que antes consistiam em conhecimento a ser transmitido de geração a geração, 
e passam, com a evolução científica e tecnológica, por uma busca intensa pela precisão. Ao que chega, no contexto contemporâneo, no qual mapas digitais e imagens de satélite passam a ter um grau de pervasividade expressiva. Para se chegar a essa condição, cartografar, ou, grosso modo, a técnica de produzir mapas de localizações, situações e processos espaciais, sofreu igualmente uma série de mudanças históricas.

Um dos fatores que permitiram esta pervasividade citada acima, além da conexão constante a redes de informação, são as mídias locativas. Esses dispositivos informacionais geram conteúdo, que se relacionam diretamente com uma localidade específica, e contribuem para qualificar e perceber o local. As mídias locativas permitem o acesso a dados georreferenciados, fotos aéreas feitas por satélites e a sistemas informacionais geográficos. E, ainda, qualquer um, de posse de um dispositivo locativo além de possuir acesso a dados na rede, também pode produzir informações geolocalizadas.

Se, em termos históricos, ser cartógrafo era o papel do conquistador, e somente o cartógrafo detinha o poder sobre a representação daquele território, atualmente o poder de exclusividade e domínio sobre uma quantidade considerável de conteúdos geo-referenciados se dilui. Como o geógrafo Crampton afirma em seu artigo Introdução à Cartografia Crítica, "nos últimos anos a cartografia está escapando do controle da elite poderosa, que exerceu domínio sobre ela por muitos séculos.”’ (2006, p.12, tradução nossa). No entanto, essa 'democratização' do papel do cartógrafo ainda é parcial, pois ainda há uma centralização de dados por parte de grandes empresas, especialmente as que disponibilizam software, aplicativos e mapas digitais para uso gratuito e popular, como Google e Facebook.

As mídias locativas não só associam os dados a posições geográficas, mas também conectam o sujeito e suas ações a uma nuvem informacional. Tais associações permitem variadas modalidades de mapeamentos de dados e novos parâmetros de edição dos mesmos. Com elas, a pervasividade informacional se amplia na vida diária dos sujeitos. Informações passam a se configurar por associações realizadas entre sujeitos e dados segundo parâmetros designados ao espaço.

1 "In the last few years cartography has been slipping from the control of the powerful elites that have exercised dominance over it for several hundred years" (CRAMPTON,. 2006, p. 12) 
Em consonância crítica com estes tempos em que a hipergeolocalização se torna ferramenta fundamental de nosso entendimento de espacialidade, surgem cartógrafos que passam a lidar com as inquietações e percepções próprias desse universo. Investigar as cartografias produzidas por mídias locativas parece ser um modo que permite indagar que tipos de representações emergem desta condição tecnológica na contemporaneidade e o que conseguem revelar. As indagações que motivam a pesquisa serão guiadas por trabalhos que denominamos aqui, à luz de alguns autores, como "contracartógrafos", os quais nesse contexto buscam, com processos cartográficos, ampliar, desviar, questionar, dar visibilidade ao que é mediado por aparelhos pessoais geolocativos.

As práticas contracartográficas, além de possuir esse caráter crítico mencionado, extrapolam a área de geografia e passam a permear outras frentes de conhecimento. $O$ foco deste trabalho se dirige às práticas contracartográficas acionadas por grupos/organizações ativistas e artistas. Dois grupos com aproximações distintas e que enfrentam o poder dos mapas trazendo visibilidade ao que é normalmente omitido e silenciado pelos mapas dominantes.

Observar como essas práticas acontecem permitirá desvendar aspectos não explícitos de poder e dominância, além de apresentar outras percepções sobre processos espaciais e localizações.

\section{ASPECTOS METODOLÓGICOS}

A partir do interesse inicial em relação ao tema das cartografias inseridas no universo informacional, a pesquisa, ao se inserir num programa de pós-graduação em arquitetura e urbanismo e no grupo de pesquisa Núcleo de Estudos das Espacialidades Contemporâneas (NEC), procurou incorporar aspectos vinculados aos campos da arquitetura e da arte.

De início, a pesquisa se debruçou sobre a obra de autores de campos disciplinares variados que tratam da "cartografia" como conceito e prática, advindos da filosofia, psicanálise, geografia, entre outros. A fim de realizar um recorte que permitisse investigar as cartografias como modos de representação de localização no contexto contemporâneo hipermediado, 
optou-se por seguir pelo campo da geografia. A geografia é a disciplina que possui maior tradição e aprofundamento em discussões de aspectos de representação locativa.

Foi preciso desbravá-la, conhecê-la e discerni-la; e definir que vozes e questões da geografia seriam matrizes estruturadoras da pesquisa passíveis de serem desdobradas. Essa investigação se iniciou por uma varredura histórica e cronológica do desenvolvimento da representação da localização, tomando por base, fundamentalmente, estudos encontrados sobre a história da geografia. Nesse sentido, foi realizada uma revisão bibliográfica entre publicações acadêmicas que se dedicavam a discutir representações cartográficas. Grande parte do material utilizado é de autoria estrangeira, visto que discussões e importantes conceitos que serão abordados surgiram no âmbito internacional, em especial nos Estados Unidos e Reino Unido.

Ao alcançar as discussões contemporâneas da geografia sobre cartografias, percebem-se as fortes inquietações que a disciplina passa diante do crescimento do universo informacional e como teóricos de destaque da disciplina passam a se dedicar a entender e a estudar com lentes críticas este contexto de disponibilidade ampliada das representações cartográficas e locativas, que antes eram tradicionais e exclusivas da geografia (GIS/GPS/Mídias Locativas).

Não obstante, ainda dentro das discussões teóricas dentro da geografia, percebe-se que os próprios autores passam a ver nas práticas artísticas uma possibilidade de revisões cartográficas. O que passa a ser de grande interesse, uma vez que já se pretendia explorar como o âmbito da arte contemporânea estava lidando com as questões informacionais georreferenciadas através do uso de mídias locativas.

É válido recobrar que o recorte estabelecido possui também o intuito de percorrer o universo informacional georreferenciado. Por isso, quando esse momento é contextualizado e desenvolvido (em especial no capítulo 2), a bibliografia consultada se apoia, em sua maioria, em reportagens jornalísticas e web sites. Tal fato se deve a que o debate e ações em tempos recentes ainda estão em processo nos círculos acadêmicos, e são ainda em pequeno número as publicações neste meio.

Foi necessária também, para abordar as práticas contracartográficas ativistas, realizar uma grande varredura de exemplos de ações ativistas que fizeram uso de tecnologias locativas. 
Essa varredura foi importante para uma visão ampliada do que tem sido feito, como essas tecnologias vêm sendo utilizadas e quais os limites e alcance que têm adquirido. Para desenvolver as discussões ao longo do trabalho, foram escolhidos alguns casos a partir da varredura inicial. Optou-se por casos exemplares que apresentassem relevância e que, em uma leitura conjunta, gerassem tensionamentos interessantes para enriquecer a discussão do trabalho.

Para a terceira parte da dissertação, as práticas contracartográficas artísticas, foi realizada uma extensa varredura de projetos artísticos com uso de mídias locativas. Neste primeiro momento, essa varredura de trabalhos e práticas artísticas foi extremamente importante para que fosse realizado um primeiro reconhecimento de como o campo da arte estava lidando com a questão da representação locativa e seus desdobramentos, além de permitir um panorama para reconhecer artistas com potenciais interessantes que pudessem contribuir com o recorte da pesquisa.

Se a intenção era selecionar práticas de artistas que trabalhassem com mediação de mídias locativas, era igualmente importante selecionar trabalhos com diferentes tensões e linhas de ações distintas. Após os estudos realizados, foram selecionados: Meridians (2005), de Jeremy Wood; Monochrome Landscapes (2004), de Laura Kurgan; Projeto correspondência (2013), de Manuela Costalima e Canal Motoboy (2007-2015), de Antoni Abad. Além de se ter notado potencialidades em cada um desses projetos, em uma leitura conjunta foi possível perceber interessantes aspectos e singularidades a serem exploradas que poderiam contribuir com a pesquisa. Este momento também contou com uma revisão bibliográfica interessante, valendo-se de várias publicações dentro do campo da arte que lidam com a questão de cartografias e localização.

\section{ESTRUTURA DA DISSERTAÇÃO}

Dentro deste escopo, no intuito de delinear o eixo da pesquisa e percorrer as indagações propostas acima foram estabelecidos três pontos de aproximação para o desenvolvimento da pesquisa. São eles: Cartografias; Mídias Locativas; Contracartografias (realizadas por 
grupos ativistas / por artistas). O trabalho foi organizado em três capítulos, o primeiro dedicado a sistematizar a cartografia como forma de representação de localizações. Percorre alguns momentos-chave das formas de representação espacial por meio de mapas e realiza uma aproximação guiada por autores da geografia a respeito da crítica à neutralidade e objetividade dos mapas, culminando na construção de termos que procuram fazer jus a essa tarefa crítica, como "mapeamento crítico", "contramapas"ou mesmo "contracartografias".

No segundo capítulo, são contextualizados aspectos das tecnologias locativas e seus desdobramentos informacionais para, então, serem apresentados e discutidos alguns exemplos de contracartografias acionadas por grupos e organizações ativistas.

O terceiro capítulo, por sua vez, dedica-se a apresentar e se aprofundar em práticas contracartográficas realizadas no âmbito da arte. A discussão é desenvolvida tendo como base quatro projetos de artistas distintos, que abordam, de formas diferentes, as contracartografias com o uso de mídias locativas.

Uma vez apresentadas em linhas gerais as frentes de aproximação do trabalho, adentraremos em seus fios condutores. O primeiro capítulo inicia pontuando modos de representação de localizações considerados chave na história da cartografia, selecionadas e alinhavadas a partir da bibliografia selecionada. Algumas pontuações históricas sobre modos de localização são captadas em referências da pré-história, do medievo, do Renascimento e do Período Pós Segunda Guerra no Séc. XX. Para todas essas contextualizações da cartografia e de seus respectivos períodos serão articulados historiadores e geógrafos especialistas, como por exemplo: Catherine Smith (Prehistoric Maps and the History of Cartography: An Introduction) ${ }^{2}$, Alessandro Scaffi (Mapping Eden: Cartographies of the Earthly Paradise) ${ }^{3}$ e David Woodward (The History of Cartography Vol.1 e Vol.3)4. Nessas pontuações será possível notar um desenvolvimento da cartografia deixando de ser apenas um instrumento de decodificação/registro e adquirindo um caráter de representação cientificista até que, em uma crise de representação durante o Pós-Guerra, a cartografia passa a ser objeto de reflexão crítica quanto ao seu poder e limitação representativa.

\footnotetext{
2 (SMITH,1987)

3 (SCAFFI 1999)

4 (WOODWARD, 1987, 2007)
} 
Num segundo momento do primeiro capítulo, o foco é direcionado à chegada das informações georreferenciadas. Para desenvolver esse contexto é realizada uma abordagem sobre eventos significativos em que a localização se converteu em variável chave. Dentre eles, por exemplo, a foto AS8-14-23835 (tirada na missão Apollo 8 - ao contornar a Lua) e a foto AS17-148$22727^{6}$ (conhecida como Blue Marble) tirada na missão Apollo 17. Fotos que, pela primeira vez, permitem o planeta ser visto do 'lado de fora'. É quando surge uma consciência do todo em que a humanidade está inserida - uma nova perspectiva de 'onde se está'. A abordagem desta análise é articulada com o contraponto das recentes imagens do planeta Terra que são uma montagem de fotos realizadas via satélite (Blue Marble Next Generation). Discussões e reflexões sobre novas representações e tecnologias locativas começarão a surgir de maneira mais enfática neste momento.

Para esse momento, autores como o estudioso em cultura digital Jason Farman e o geógrafo Denis Cosgrove são importantes. O primeiro desenvolve uma reflexão que evidencia as mediações tecnológicas e de como ainda há uma centralidade informacional, enquanto o geógrafo foca em uma leitura crítica em relação ao tipo de informação que essas representações geram e como essas informações se articulam com o imaginário de localização dos sujeitos.

No terceiro momento do primeiro capítulo, aprofunda-se no desenvolvimento de visões críticas dentro da geografia e como as indagações e questionamentos vêm atuando, no sentido de posicionar a representação e a localização em uma perspectiva política. Momento chave que, além de procurar entender como se desenvolvem as lentes críticas sobre a cartografia, apresenta uma primeira aproximação ao tema das "contracartografias".

Entre as referências bibliográficas desse tópico estão alguns dos principais cartógrafos críticos do século XX, como J.B.Harley (Deconstructing the Map) ${ }^{7}$, Jeremy Crampton (An Introduction to Critical Cartography) ${ }^{8}$ e Denis Wood (Rethinking The Power of Maps) ${ }^{9}$. Os questionamentos levantados pelos autores passam a ampliar a compreensão sobre os papéis

\footnotetext{
5 Foto AS8-14-2383-Realizada em 24 de dezembro de 1968

6 Foto AS17-148-22727 (Blue Marble) Realizada 7 de dezembro de 1972

7 (HARLEY 1987)

8 (CRAMPTON 2015)

9 (WOOD 2010)
} 
desempenhados pelos mapas e direcionar a reflexão para temas como o emissor, o contexto em que a cartografia é produzida e até mesmo a desconstrução da neutralidade dos mapas.

O segundo capítulo é o momento em que será feita uma contextualização mais detalhada da pervasividade informacional e das mediações através de mídias locativas e dos mapas digitais colaborativos. O texto centra foco nos mapas colaborativos e em algumas de suas influências sociais, econômicas e políticas no cotidiano contemporâneo. Destacam-se, nesse momento, autores como o geógrafo Georg Gartner (Web mapping 2.0) e Albarracín Santiago (Towards a new Datascape ). O primeiro autor é relevante para o entendimento de como as dinâmicas dos mapas colaborativos realmente ocorrem e de como estes sistemas, que inicialmente parecem democráticos, possuem uma centralidade velada de captação e retenção de informações. Santiago, por sua vez, traz exemplos práticos e reflexões de interferências diretas que mapeamentos colaborativos podem ter em uma cidade.

No segundo momento do capítulo, a aproximação é conferida às contracartografias ativistas, para entender como grupos e organizações ativistas se utilizam dos mapas colaborativos para levantar suas questões e suas reinvidicações. Serão resgatados aspectos que caracterizam uma contracartografia e aspectos de visibilidade e invisibilidade que são enfrentados. Nesse momento, são resgatados autores como Michel Foucault (So Is It Important to Think?), que trará o entendimento de crítica adotado na pesquisa, e Brian Holmes (counter cartographies). É apresentado o caso de Ushahidi, iniciativa ativista que encontrou nos mapas colaborativos eficiência e engajamento necessários para a causa deles do momento para denúncia de atos violentos políticos. Serão citados alguns outros exemplos de contracartografias ativistas que, em uma leitura conjunta podem trazer interessantes tensões e evidenciar ações de visibilidade a um universo que costuma ser velado por mídias e mapas hegemônicos.

No terceiro capítulo, em que a atenção se volta às práticas contracartográficas no âmbito artístico, o interesse está em entender como a arte contribui em suas ações contracartográficas, com o recorte temporal proposto para a pesquisa. Como artistas lidam com o binômio de visibilidade e invisibilidade, e como trazem outras chaves de compreensão ao papel da cartografia, os sistemas informacionais geolocativos e mídias locativas. São apresentados autores como Marc Tuters e Kazys Varnelis (Beyond Locative media), que se ocupam 
em entender a chegada das midias locativas na artes visuais e também autores como Ben Russel (Transcultural map online reader introduction). Para isso, são apresentados quatro projetos artísticos distintos; inicialmente cada projeto é focado individualmente para, posteriormente, ser construída uma leitura conjunta e articulada entre os quatro projetos. Como já mencionados, os quatros projetos artísticos são: Meridians (2005), de Jeremy Wood; Monochrome Landscapes (2004), de Laura Kurgan; Projeto correspondência (2013), de Manuela Costalima e Canal Motoboy (2007-2015), de Antoni Abad

Após o terceiro capítulo, as considerações finais articulam conexões entre os temas e questões levantadas nos três capítulos, além de encerrar em algumas conclusões e desdobramentos possíveis que surgiram ao longo da pesquisa.

\section{TERMOS RELEVANTES}

Visto que este trabalho lida com diferentes disciplinas e campos de conhecimento, se faz necessário estabelecer o entendimento de alguns termos principais que permeiam o trabalho. A começar pelas palavras 'Mapas' e 'Mapeamento', que, em um primeiro momento, podem parecer similares, mas não são. Entende-se 'mapas' como um produto, uma expressão que conta sobre algum lugar. Um mapa pode ter diversos formatos, podendo ser escrito, cantado e desenhado. O mapa formata o nosso entendimento do mundo. Robert Tally Jr. bem aborda em seu livro 'Spatiality' (2013) quando discorre sobre mapas.

“O mapa é um dos mais poderosos e efetivos meios que seres humanos têm para dar sentido ao seu lugar no mundo, [...] o mapa oferece uma representação fictícia ou figurativa do espaço em que nos encontramos e a flecha ou ponto ou outro marcador 'você está aqui' fornece o ponto tranquilizador de referência a partir do qual podemos imaginar e navegar no espaço."10 (TALLY, 2013, p. 2, tradução nossa)

\footnotetext{
10 "The map is one of the most powerful and effective means humans have to make sense of their place in the world, [...] the map offers a fictional or figurative representation of the space in which we find ourselves, and the reassuring 'you are here' arrow or dot or other marker provides the point of reference from which we can both imagine and navigate the space." (TALLY, 2013, p.2)
} 
Já o 'mapeamento' está mais associado a um processo de construção de um pensamento espacial. Os geógrafos Kitchin, Perkins e Dodge definem mapeamento como:

“O mapeamento é epistemológico, mas também profundamente ontológico

- é uma maneira de pensar sobre o mundo, oferecendo um quadro para

o conhecimento e um conjunto de afirmações sobre o próprio mundo"11

(KITCHIN; PERKINS; DODGE, 2009, p. 1, tradução nossa)

O termo 'cartografia', por sua vez, pode ser encontrado no campo da geografia sendo utilizado como um sinônimo de mapas/cartas; ou até mesmo, é possível encontrar explicações tradicionalistas significando a transferência de dados geográficos para uma superfície plana (carto-grafia). Neste trabalho, adotamos o entendimento dado pelo geógrafo J.B.Harley que define cartografia como:

"um corpo de saberes teóricos e práticos que os fazedores de mapas utilizam para construir mapas como um modo distinto de representação visual"12 (HARLEY, 2001, p. 153, tradução nossa)

Outro termo, que será de extrema importância e que, inclusive, intitula o trabalho, é 'contracartografias'. Esse termo será reapresentado mais detalhadamente no decorrer do trabalho, aí já apoiado em outros conceitos. No entanto, de forma sucinta, o termo 'contracartografia' se vincula ao pensamento e práticas críticas que envolvem mapeamentos e mapas, os quais estão voltados a enfrentar autoridades, poderes ou desafiar percepções espaciais estabelecidas. Este termo pode ser encontrado em muitas das literaturas da geografia como contramapeamento (counter-mapping). No entanto, como será elucidado mais adiante, o termo que será utilizado neste trabalho será 'contracartografia' - tomando-se como referência o termo utilizado pelo artista-ativista Brian Holmes.

Haverá momentos nesta pesquisa em que outro termo será utilizado: ‘(contra)cartografia’. Isso

\footnotetext{
11 "Mapping is epistemological but also deeply ontological- it is both a way of thinking about the world, offering a framework for knowledge, and a set of assertions about the world itself.' (KITCHIN; PERKINS; DODGE, 2009, p. 1)

12 "Cartography I define as a body of theoretical and practical knowledge that map makers employ to construct maps as distinct mode of visual representation" (HARLEY, 2001, p. 153)
} 
acontecerá quando houver a intenção de fazer referência a uma situação em que dois modos de operar dos mapas estão em funcionamento, sendo um o de 'cartografia' como sinônimo de mapa, com todos os valores que o termo carrega, e o outro como contracartografia, no sentido já explicado acima.

Outro conjunto de vocábulos que se faz necessário elucidar antes de seguirmos adiante são as palavras do universo informacional. Algumas delas serão abordadas ao longo do trabalho, no entanto, três delas são chaves e, dada sua importância, já as abordaremos aqui no início. São elas: GIS, GPS e Mídias Locativas.

A sigla GIS, utilizada com frequência, é inclusive objeto de indagação e crítica na geografia, como será mostrado nos capítulos seguintes. O GIS (Geographic Information System) é um nome atribuído a um software que permite localizar dados espacialmente. Permite que qualquer tipo de informação seja vinculado diretamente com um ponto de coordenadas espacial. Os autores Paul Longley, Michael F. Goodchild, David Maguire e David Rhind, no livro Geographic Information Systems and Science: Principles, Techniques, Management, and Applications, apresentam o "campo de GIS preocupado com a descrição, explicação e bem como previsão de padrões e processos em escalas geográficas. GIS é uma ciência, uma tecnologia, uma disciplina e uma metodologia aplicada de solução de problemas." ${ }^{13}(2005$, p. Xi, tradução nossa)

Como será abordado no trabalho mais adiante, a chegada do GIS trouxe uma inquietação a teóricos da geografia. Segundo Kurga,n a tecnologia é conhecida por ter "transformado a cartografia em uma administração de dados espaciais." ${ }^{14}$ (2013, p.52, tradução nossa)

Existem, segundo o geógrafo John Pickles, duas características centrais definidoras do GIS. Uma é o papel de dados digitais eletrônicos, e a outra é produção eletrônica de representações especiais desses dados. Em outras palavras, o GIS, de modo geral, é um produto computacional de tecnologia de informação eletrônica.

13 "field of GIS as concerned with the description, explanation, and prediction of patterns and processes at geographic scales. GIS is a science, a technology, a discipline and an applied problem solving methodology." (LONGLEY, et al. 2005, p. Xi)

14 “[...]having transformed cartography into spatial data management." (2013, p.52) 
"Na medida em que ampliou nossa visão de como os dados e a informação podem ser vinculados de maneiras novas e interessantes, o GIS trouxe mudanças significativas e de longo alcance na pesquisa científica, agências públicas e privadas e a estrutura disciplinar da geografia."15 (PICKLES, 1995 , p. 641, tradução nossa)

Com a tecnologia GIS é possível integrar dados, dispositivos e pessoas com o objetivo de coletar, armazenar, editar, visualizar e analisar dados georreferenciados a um sistema de coordenadas conhecido. Permite precisamente que informações sejam geolocalizadas e processadas.

O GPS (Global Positioning System) se mostra mais concreto quando comparado ao GIS. O GPS é um sistema composto por dezenas de satélites que orbitam o planeta e que possibilitam que pessoas com receptores específicos (equipamentos GPS) identifiquem sua localização geográfica. É uma tecnologia militar americana, desenvolvida pelo Departamento de Defesa Norte Americano na década de 70. Porém, a tecnologia tornou-se totalmente operacional no início da Guerra do Golfo (década de 90). Na época, a tecnologia GPS era utilizada para guiar armamentos que voavam nos campos de batalhas da guerra.

Foi somente em 2000, no governo Clinton, que a tecnologia GPS passa a ser disponibilizada gratuitamente ao público, como uma tecnologia de ajuda locativa, ou seja, com a promessa de se saber exatamente onde se está.

"Onde estamos, hoje em dia, parece menos uma questão de locais fixos e pontos de referência estáveis e mais uma questão de redes, isto é, de deslocamentos e transferências, de nós definidos apenas pelo seu

\footnotetext{
15 "Insofar as it has enlarged our vision of how data and information can be linked in new and interesting ways, GIS has brought about far-reaching and significant changes within scientific research, public and private agencies, and the disciplinary structure of geography." (PICKLES, 1995, p. 641)
} 
posicionamento relativo no campo de deslocamento"16 (KURGAN, 2013, p. 61, tradução nossa)

Como a aderência foi intensa, em 2004 o Governo J.W.Bush instituiu o National Executive Committe for Space-Based Positioning, Navigations and Timing (PNT) e adotou um comitê de manutenção do GPS como uma utilidade mundial gratuita. Hoje, dispositivos conectados ao GPS estão presentes na rotina diária de um número expressivo de civis no mundo todo, presente em veículos de transportes e inclusive em todos os aplicativos geolocativos.

Mídia locativa é outro termo a ser abordado aqui. O termo designa dispositivos eletrônicos móveis que possuem tecnologias GIS e/ou GPS. Os eletrônicos que compõem essa categoria são os smartphones, aparelhos GPS, tablets, notebooks, smartwatches etc. É nas mídias locativas que, atualmente, se consomem e se produzem conteúdos on line. É para esses aparelhos que aplicativos geolocativos e mapas colaborativos são desenvolvidos. Pois, além de serem aparelhos desenvolvidos para fácil mobilidade, estão constantemente conectados à rede alimentando e sendo alimentados por informações de acordo com o perfil de seu usuário. No capítulo 2, esta relação se fará mais clara, quando alguns exemplos de aplicativos e mapas colaborativos forem abordados, mas o que vale ressaltar neste momento é que se trata de uma tecnologia de hardware que permite a pervasão intensa da tecnologia GIS e GPS e o interminável input de dados feitos pelos usuários.

16 "Where we are, these days, seems less a matter of fixed locations and stable reference points and more a matter of networks, which is to say of displacements and transfers, of nodes defined only by their relative positioning in shifting field." (KURGAN, 2013, p.61) 
INTRODUC̣ÃO 


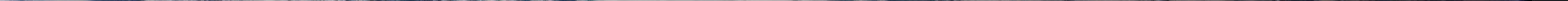




\section{Capítulo 1}

\section{Linhas Cartográficas}




\title{
1.1 PRECEDÊNCIAS HISTÓRICAS SOBRE A REPRESENTAÇÃO DE LOCALIZAÇÕES
}

\begin{abstract}
“A principal preocupação da história da cartografia é o estudo do mapa em termos humanos. Como mediadores entre um mundo interno mental e um mundo físico externo, mapas são ferramentas fundamentais que auxiliam a mente humana fazer sentido de seu universo em várias escalas. Mais que isso, eles são indubitavelmente uma das mais antigas formas de comunicação humana." ${ }^{17}$ (HARLEY, 1987, p.1, tradução nossa)
\end{abstract}

Mais que um instrumento de localização, a cartografia é um instrumento de registro e comunicação de um indivíduo, um Estado e até mesmo de uma sociedade. Entender o contexto histórico e quais as situações sóciopolíticas em que uma cartografia está inserida ou as quais revela - torna-se fundamental.

$\mathrm{Na}$ história da cartografia, não existe um tempo matematicamente preciso que marque o seu início. Historiadores e geógrafos tradicionalmente dedicaram sua atenção à história da cartografia a partir do povo babilônico e egípcio, ignorando, em grande parte, os estudos do Período Pré-Histórico do Velho Mundo. A preocupação com a cartografia desse período é recente; segundo a historiadora Catherine D. Smith em seu ensaio Cartography in the Prehistoric Period in the Old World:Europe, The Middle East, and North África (1987), o assunto passa a ser tratado de maneira tímida em $1910^{18}$, mas passa a ser referenciado com expressão a partir dos anos 60 .

Muitos autores consideram como início da cartografia o momento em que o ser humano

17 " The principal concern of the history of cartography is the study of the map in human terms. As mediators between an inner metal world and an outer physical world, maps are fundamental tools helping the human mind make sense of its universe at various scales. Moreover, they are undoubtedly one of the oldest forms of human communication." (HARLEY, 1987, p.1)

18 Em 1910 Bruno F. Adler discute duas placas de ossos, os quais Fritz Rodiger (um antiquarista alemão) havia sugerido que fossem mapas. (SMITH, C.D. 1987:54) 
desenvolve seu sense of place ${ }^{19}$. Em outras palavras, significa o momento no qual o homem entende o sentido e relação entre o 'aqui' e o 'lá', quando organiza essa informação mentalmente e a transmite:

“[...] a experiência de espaço e lugar, o desejo ou a necessidade de mapear, e a reflexão de uma consciência no sentido de se atingir um sense of place habitável ou mapas melhores não são novos na história da humanidade. À medida que os seres humanos são animais sociais [...] e são também animais espaciais [...]"20 (TALLY, 2013, p.16, tradução nossa)

Há geógrafos como G. Malcolm Lewis que relacionam de forma direta a formação da comunicação e linguagem humana com o senso espacial. Segundo um ensaio que publicou no livro The History of Cartography $(1987)^{21}$, o Homo Sapiens de aproximadamente 40 mil anos atrás já se movia no espaço de maneira considerável e já desenvolvia habilidades para sobreviver frente às adversidades do meio que o cercava. A necessidade do Homo Sapiens de sobreviver aos mais hostis ambientes foi decisiva para o desenvolvimento da visão, um dos cinco sentidos que, para o autor, permitiu a base sensorial necessária para desenvolver um esquema mental espacial. A sobrevivência não dependia somente dessa consciência espacial e da visão individual, também dependia da cooperação entre indivíduos, o que levou o Homo Sapiens a desenvolver uma comunicação com o outro. E assim, para Lewis, a linguagem humana começa a se formar e, por isso, possui uma ligação significativa com o entendimento espacial.

Mesmo Careri, arquiteto e autor do livro Walkscapes, ao delinear a relação do homem com seu meio no Período da Pré-História, afirma que, muito antes de uma relação com o meio construído, veio a errância. O caminhar vinculado ao perder-se ou como o próprio autor

19 Sense of place (senso de lugar) no entendimento elaborado pelo geógrafo Yi-Fu Tuan: ligação afetiva entre pessoa e lugar ou ambiente; relação essa que varia em intensidade, sutileza e em formas de expressão; resposta ao meio, que pode se dar de forma estética, táctil ou emocional. TUAN, Yi-Fu. Space and Place: The perspective of experience. Minneapollis, University of Minnesota Press. 1977.

20 Texto original: “[...] the experience of space and place, the desire or need for mapping, and the self-conscious reflection on ways and means of achieving a more liveable sense of place, or a better map, are nothing new in human history. To the extent tha human beings are social animals [...] they are also spatial aniamals [...]" (TALLY, 2013:16)

21 Livro editado por J.B. Harley e David Woodward. 
chama 'o espaço do ir'. Para ilustrar, o autor menciona o primeiro registro da existência do homem, os passos de um Australopithecus ${ }^{22}$ (Figura1). Trata-se do primeiro registro da existência do homem, que data de aproximadamente 4 milhões de anos atrás. Vale perceber que a mais antiga marca do homem no planeta trata-se de uma marca de movimentação, um rastro que indica o deslocamento no espaço, enquanto que registros/marcas deixados pelo homem que sugerem qualquer coisa de sedentarismo vêm em tempos significativamente posteriores. Percebe-se que a errância já era algo natural do ser humano antes mesmo de adquirir características sedentárias e fixas.

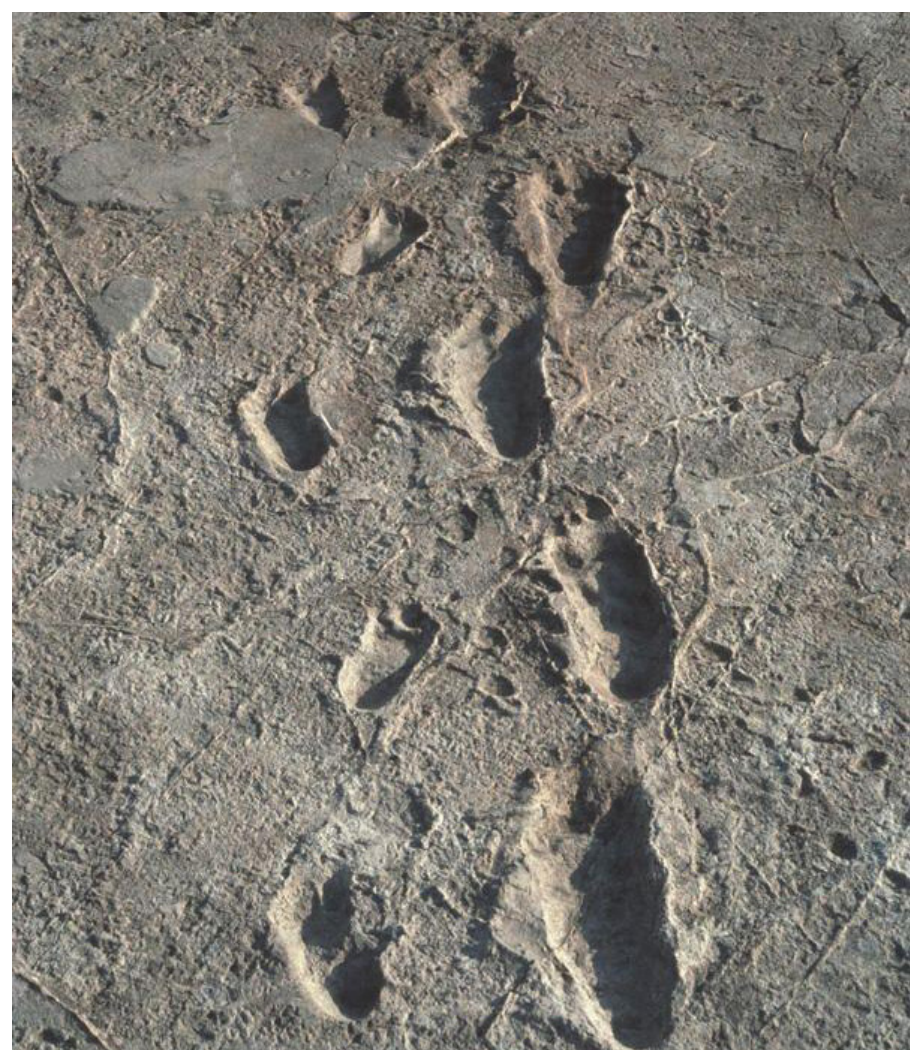

Figura 1- Passos de australopiteco, Laetoli, Tanzânia. As marcas demonstram a habilidade da locomoção bípede e de forma ereta. As marcas das pegadas também indicam habilidades de subir em árvores. Fonte: bradshawfoundation.com

Essa errância do homem, para o autor, antecede o conceito do nomadismo. E antecede igualmente o Período Paleolítico, ou seja, muito antes de construções de templos e cidades.

22 Descoberta publicada em 79 na Revista Nature (Leakey, M. D. and Hay, R. L. - Pliocene footprints in the Laetolil Beds at Laetoli, northern Tanzania - Nature) 
No entanto, quando se alcança o estágio do nomadismo, se atinge de forma conjunta o sedentarismo. Um binômio (Sedentarismo x Nomadismo) que forma uma tensão natural da espécie humana.

“O mapa nômade é um vazio onde os percursos unem poços, oásis, lugares sagrados, terrenos bons para apascentamento e espaços que mudam velozmente. É um mapa que parece refletir um espaço líquido em que os fragmentos cheios do espaço do estar flutuam no vazio do ir, em que percursos sempre diversos permanecem até ser apagados pelo vento." (CARERI, 2013, p. 42)

O fato é que, apesar das diversas teorias desenvolvidas, trata-se de um tempo de poucos registros; pouco se sabe sobre os primórdios e são raros os registros e descobertas do Período Pré-Histórico. Não foram muitos os vestígios desse período que suportaram a passagem do tempo e que, em especial, demonstram o desenvolvimento da relação humana com um senso espacial. Talvez uma das descobertas mais significativas, que indique essa relação seja a pintura na parede Çatalhöyuk, na Turquia (6200 AC) que é parte de uma descoberta arqueológica importante, especialmente por indicar que se trata de um mapa do Período Neolítico. Sua importância se dá particularmente por ter sido possível sua datação, visto que foi encontrada em meio a uma complexa escavação de vestígios e artefatos. Paralelamente, foi também muito bem documentada e aparentemente é a única pintura do território no Velho Mundo, do Período Pré-Histórico, que registra uma representação de um ajuntamento humano construído.

A pintura possui aproximadamente três metros de comprimento, e estudiosos identificaram em sua representação o registro em planta dos assentamentos, visto que são muito coincidentes com a escavação de um assentamento encontrado na mesma área de investigação e de descoberta da pintura (Figura 2). Outro aspecto apontado pelos estudiosos é a representação da montanha Hasan Dag em perfil com seu vulcão em erupção. As escavações, segundo a geógrafa Catherine D. Smith, indicam que essa pintura está associada a um ambiente sagrado, e desconfia-se que a pintura seja resultado de um ritual e não algo feito com o intuito de registro durável. 


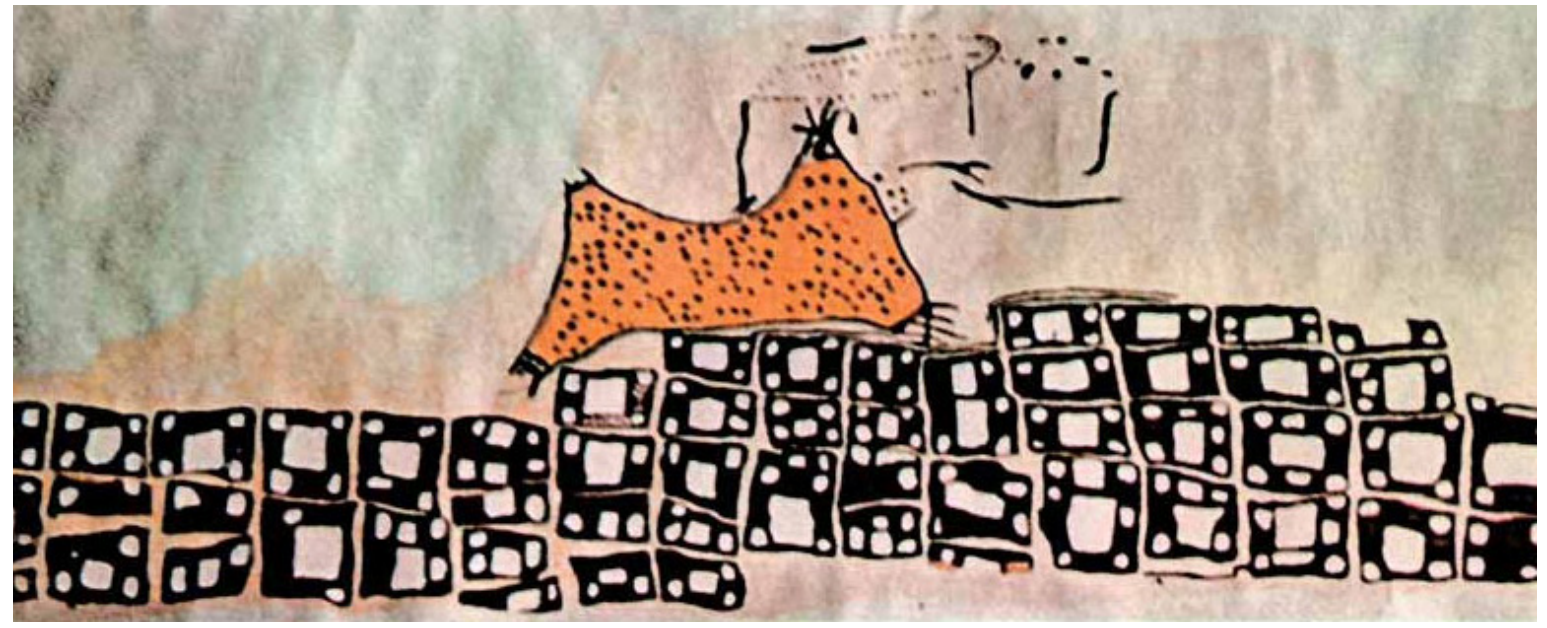

Figura 2- Çatalhöyuk (6200AC) Arqueólogos identificam na imagem a representação da área das residências, devido à sua similaridade com uma área que também encontraram na escavação. Atrás da área identificada, há o que está representado em perfil no desenho: a montanha Hasan Dag com o seu vulcão em atividade.

Fonte: Sci-news.com.

É interessante notar que a pintura em questão pode revelar, do ponto de vista deste estudo, dois aspectos importantes. A pintura é composta por dois momentos distintos que mostram uma variação significativa desta relação do homem e seu espaço. O primeiro é a faixa inferior da representação em planta dos assentamentos, ou seja, uma vista abstrata da totalidade, um momento em que o sujeito não se insere no espaço representado. $\mathrm{O}$ segundo momento, a montanha Hasan Dag, representada em perfil, já mostra o sujeito implicado. Apesar de não tão implicado como seria em uma perspectiva, esse modo representativo demonstra uma certa escala, importância e grau de significância da montanha e da natureza em relação ao primeiro momento.

Além da pintura de ÇatalHüyük, há também as diversas gravuras rupestres na região de Val Camonica. Em especial, chama atenção uma imagem gravada numa rocha em Bedolina, pertencente à mesma região. Esta gravura data aproximadamente de $10.000 \mathrm{AC}$ e representa a dinâmica de um vilarejo paleolítico e a vida cotidiana de seus habitantes (Figura 3).

Essa imagem se aproxima muito do entendimento comum de mapas, especialmente pela presença de linhas que conectam diversos elementos diferentes, o que nos leva a pensar em caminhos e rotas. A dinâmica visual que possui ocorre devido às inúmeras conexões dentre 

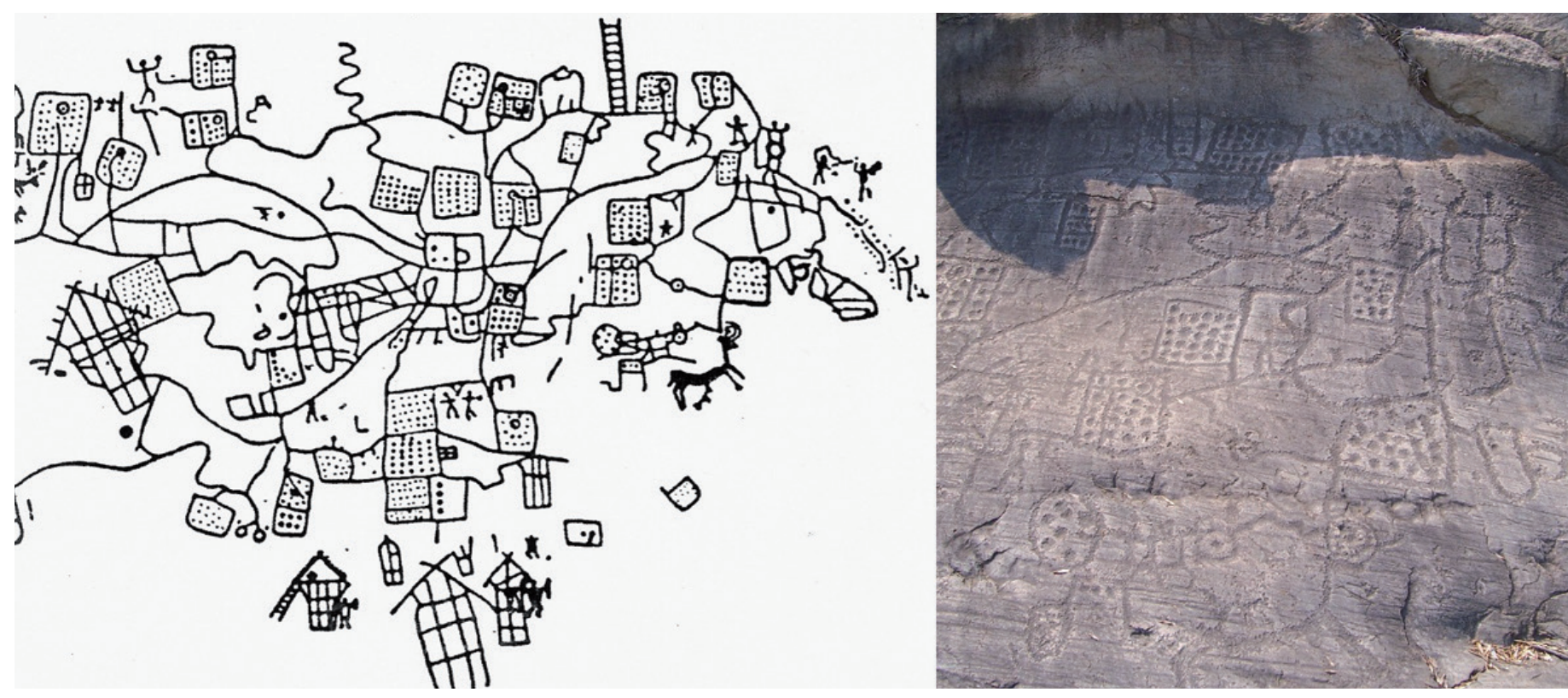

Figura 3- Val Camonica (10000 AC) Fonte: rcg.cat

os elementos, à variação das representações em planta ou em vista e especialmente por haver elementos de cenas de atividades humanas como caça e sinalizações de construções, escadas e inclusive delimitações espaciais. Saber o que realmente cada um desses elementos significa é difícil afirmar, mas é significativo perceber que houve a necessidade de o homem daquela época externar e registrar, de alguma maneira, a sua relação espacial cotidiana.

São diversas as maneiras com que se pode interpretar registros como esses de Val Camonica e ÇatalHüyük. Smith aponta que, para historiadores/arqueólogos que se ocupam em estudar registros de períodos como esses, há uma grande dificuldade metodológica e investigativa “ $\mathrm{O}$ grande problema conceitual envolve a atitude do pesquisador diante da cultura pré-histórica e indígena. A mente moderna tem seu olhar vedado por sua própria alfabetização [...]" ${ }^{23}$ (SMITH, 1987, p. 58, tradução nossa).

Mesmo diante de avanços nas pesquisas e estudos arqueológicos, colocar a história da cartografia em uma linha do tempo retilínea, seria uma atitude limitadora. Para o historiador

23 "The greatest conceptual problem involves the researcher's attitude to indigenous and prehistoric cultures. The modern mind is blinkered by its own literacy [...]" (SMITH, 1987:58) 
Christian Jacob $^{24}$ (1999), a história da cartografia não pode ficar confinada à história da ciência e ao conhecimento geográfico stricto sensu. Como cada cartografia abrange muitos componentes culturais de seu tempo, o autor defende que o contexto cultural é a chave para compreender a evolução e a transformação que a cartografia sofre ao longo do tempo.

Entender o contexto cultural de uma sociedade é fundamental para compreender suas manifestações cartográficas, mesmo que ela não se dê ainda na forma de uma representação gráfica. Careri (2013) cita, por exemplo, uma tribo aborígene australiana que mapeou a região por meio de cânticos que eram transmitidos de geração em geração. Essas canções funcionavam como o autor mesmo nomeia de "guias cantados", em cuja letra descrevem os espaços e trajetos a serem percorridos.

"Cada montanha, cada rio e cada poço pertence a um conjunto de histórias/ percursos - as vias dos cantos - que, entrelaçando-se continuamente, formam uma única 'história do tempo do sonho', a história das origens da humanidade. A cada um desses percursos está ligado um canto e a cada canto está ligada uma ou mais estórias mitológicas ambientadas no território.” (CARERI, 2013, p. 44)

$\mathrm{Na}$ antiga Grécia, por exemplo, o conhecimento geográfico não dependia de mapas no formato tradicional como entendemos, mas sim de cadernos de viagens, textos e discursos de viajantes que eram transmitidos oralmente. Nesse caso, mesmo não havendo o mapa, no sentido tradicional de representação gráfica de limites e fronteiras, já podemos considerar esses outros registros, o discurso oral e textos, como cartografias (veremos mais adiante, ainda neste capítulo, como esses diversos tipos de linguagem podem ser entendidos como cartografias).

Em ambos os casos, tanto os cânticos dos aborígenes australianos quanto os discursos orais dos gregos são registros oriundos de uma experiência de mundo percorrida por alguém. Essas informações passam a existir porque houve um sujeito implicado na trajetória que, após experienciá-las decodifica e registra suas impressões para passar adiante.

24 Christian Jacob: Pesquisador no Centre National de La Recherche Scientifique, Paris. Sua área principal de atuação é história da cartografia e geografia antiga. 
O filósofo grego Strabo (63 AC), por exemplo, foi autor de um importante tratado constituído de 17 livros, chamado Geographicae ${ }^{25}$. Estudioso, viajou muito pelo mundo, o que o motivou a registrar os lugares que havia conhecido. A sua obra descreve em forma de texto características geográficas espaciais dos diversos lugares percorridos, além de hábitos e costumes dos mais diversos povos. Ainda em seu texto, procura indicar de forma descritiva, a partir dos dados que recolheu, uma proposta de representação dos lugares que percorreu, por meio de um mapa visto por cima. Interessante notar essa preocupação de se autoextrair do contexto espacial levantado para buscar uma representação 'imparcial', especialmente tendo dados adquiridos de forma tão empírica.

Outro importante personagem que contribuiu para o desenvolvimento dos estudos cartográficos foi Ptolomeu, astrônomo, geógrafo e matemático, que desenvolveu boa parte de seus principais trabalhos no período de 127 a 150 DC. Dentre vários trabalhos, retoma e desenvolve pensamentos escritos por estudiosos anteriores, dentre eles Strabo. Ptolomeu elaborou um mapa do mundo com uma malha de coordenadas de longitude e latitude. Dentre suas principais obras está Geographia ${ }^{26}$.

Ambos, Strabo e Ptolomeu, indicaram em seus textos construções de mapas em superfícies esféricas e em formato plano, apesar de ambos indicarem maior preferência pelo formato esférico, pois acreditavam que abrigariam menores distorções. Strabo, por exemplo, apenas deixou descrições textuais e não ilustrativas. Tempos depois, em 1883, Edward Herbert Bunbury publicou a ilustração que representa os textos de Strabo (Figura 4). O trabalho de Ptolomeu sobreviveu à Idade Média graças aos Bizantinos, que se ocuparam em traduzir as obras para o latim e preservá-las na biblioteca de Alexandria. Tais obras foram resgatadas e utilizadas como referência para estudos cartográficos no Renascimento. Este trabalho de Ptolomeu, diferentemente do de Strabo, continha ilustrações esquemáticas de sistemas conceituais matemáticos. Em especial estudos e esquemas matemáticos de quatro possíveis projeções de mapas do globo para uma superfície plana. Ptolomeu, em seu trabalho, dedica-

25 Geographicae (Geografia): Escrito por Strabo, é um tratado composto por 17 volumes - boa parte desses volumes conservados até hoje - que descreve a geografia do mundo segundo as experiências empíricas do autor.

26 "Geographia" : Escrita por volta de 150 d.C., é composta por 8 volumes. O volume 1 discute princípios da cartografia matemática e os métodos de representar superfícies esféricas no plano; os demais volumes tratavam-se de uma listagem de nomes de lugares, cidades, ilhas, montanhas etc...com suas respectivas localizações (coordenadas com precisões de minutos e segundos). 


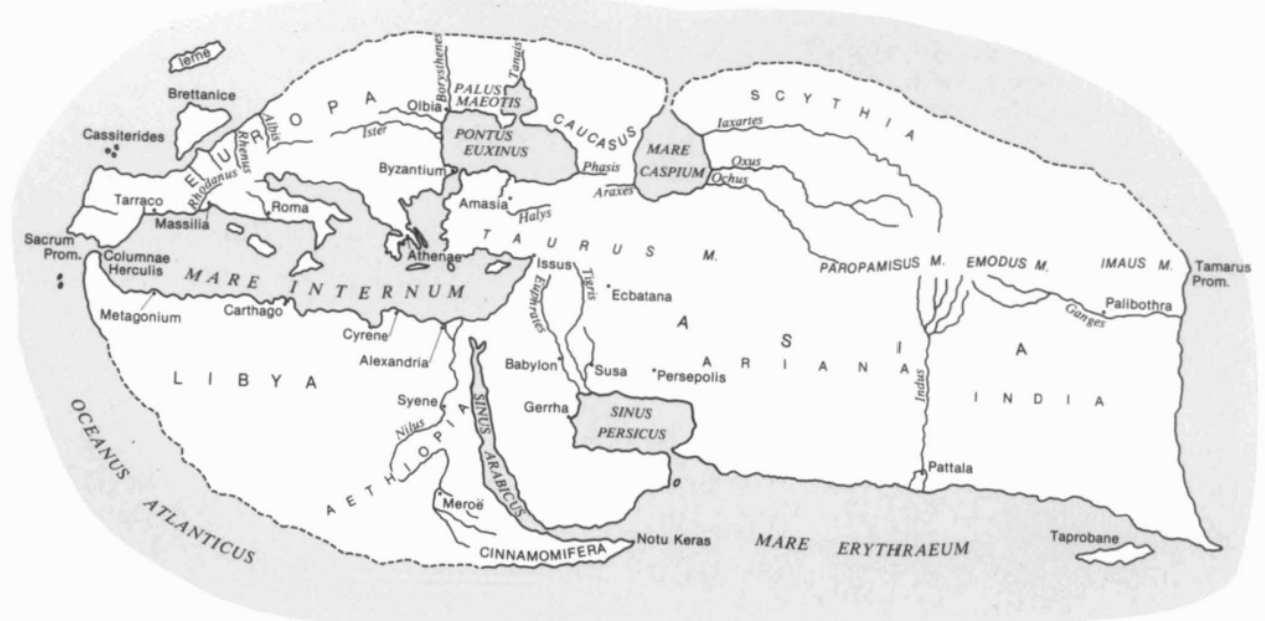

Figura 4- Mapa feito a partir dos textos deixados por Strabo. Publicado por Edward Herbet Bunbury 'A History of Ancient Geography among The Greeks and Romans from the Earliest Ages till The Fall of The Roman Empire'-1883.

se ao embasamento matemático de projeções e soluções de representações; no entanto, encontram-se ilustrações de mapas geográficos junto ao seu material traduzido pelos Bizantinos e não se sabe ao certo se esses mapas que ilustram o documento traduzido são de autoria de seus tradutores ou se eram realmente parte do material original. No entanto, Edward H. Bunbury também se ocupa em ilustrar o mapa de acordo com as indicações deixadas por Ptolomeu (Figura 5).

É apenas na Idade Média, segundo o historiador Alessandro Scaffi ${ }^{27} \mathrm{em}$ seu ensaio Mapping Eden: Cartographies of the Earthly Paradise, que a cartografia se converteu em representações primordialmente gráficas. Um pouco mais próximas ao que entendemos por mapas/atlas tradicionais, mas com a diferença de que tinham como responsabilidade primeira transmitir um discurso filosófico e teológico, mais localizações e descrições de lugares reais. Nas palavras de Scaffi, "Na cultura medieval européia, o debate filosófico sobre a inter-relação de espaço e tempo era profundamente Teológico"²8 (1999, p. 50).

27 Alessandro Scaffi: Geógrafo, Doutor e pesquisador na Área de Cartografias da Idade Média.

28 "In medieval European culture, philosophical debate about the interrelationship of space and time was profoundly theological" (SCAFFI, 1999, p.50) 


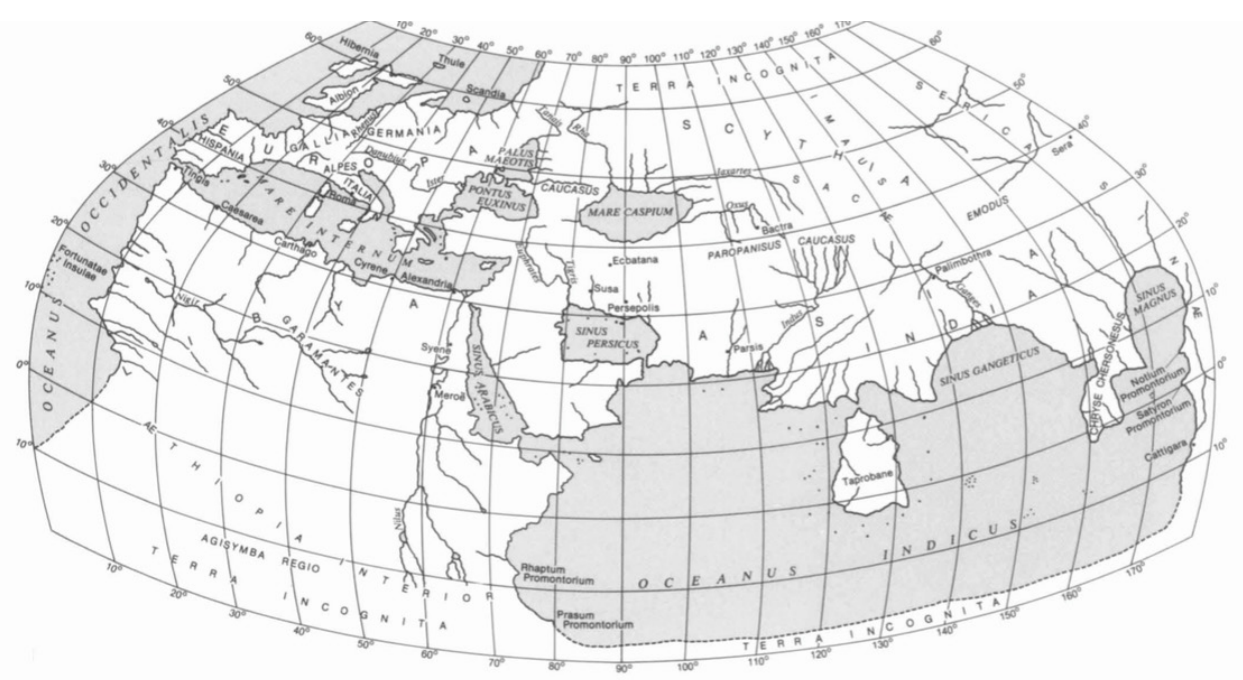

Figura 5- Mapa feito a partir dos textos deixado por C.Ptolomeu. Publicado por Edward Herbet Bunbury 'A History of Ancient Geography among The Greeks and Romans from the Earliest Ages till The Fall of The Roman Empire'-1883.

Para ilustrar essa característica das cartografias medievais, podemos tomar como exemplo um dos mais célebres mapas do período: O mapa Ebstorf (Figura 6), datado do século XIII, que representa o mundo como corpo de Cristo.

Durante a transição da Idade Média para o início do Renascimento, a cartografia sofre mudanças de maneira progressiva e não de forma abrupta como se costuma imaginar. David Woodward ${ }^{29}$, em seu ensaio no Livro The History of Cartography, afirma que muitos dos mapas do Renascimento persistiam com o conteúdo teológico, no entanto, ressalta em seu ensaio aspectos interessantes como: "Entre 1400 e 1472, na era do manuscrito, foi estimado que havia alguns milhares de mapas em circulação; entre 1472-1500, aproximadamente 56 mil; e entre 1500-1600, milhões" ${ }^{\prime 30}$ (2007, p. 11). Esse número crescente de mapas em circulação é significativo e o autor destaca que esse aumento se dá devido à variedade de funções político-econômicas a que os mapas são destinados, desde determinações de limites

29 David Woodward (1942-2004): Historiador americano especializado em História da Cartografia. O Livro "The History of Cartography".Vol.3 foi editado por ele e publicado após seu falecimento, no ano de 2007.

30 "Between 1400 and 1472, in the manuscript era, it has been estimated that there were a few thousand maps in circulation; between 1472 and 1500, about 56000; and between 1500 and 1600, milions." (WOODWARD, 2007, p.11) 


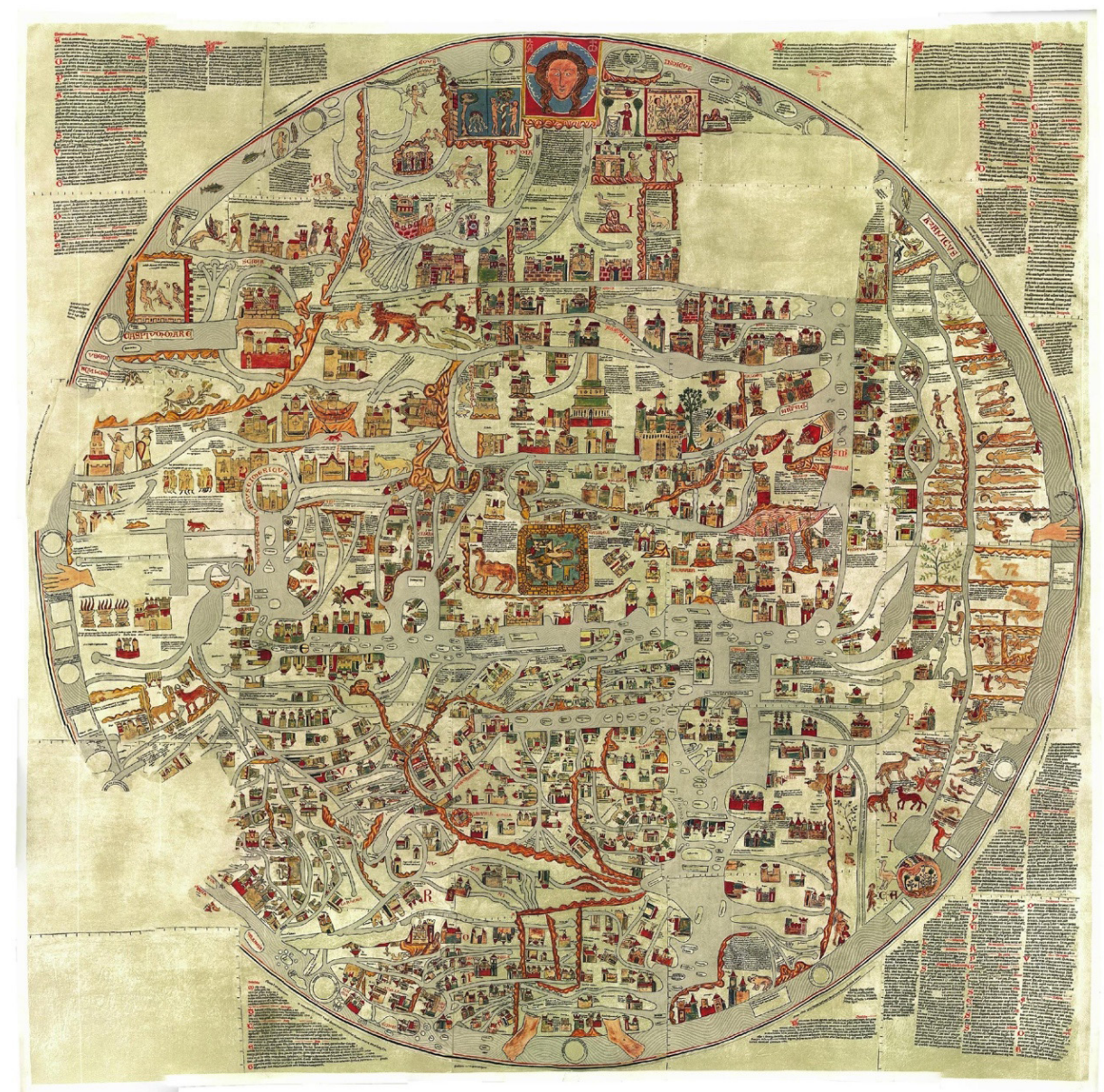

Figura 6 - Mapa Ebstorf (1236). Representa o mundo como corpo de Cristo. O Original (3,56 x 3,58m) foi destruído durante bombardeios da Segunda Guerra Mundial, restando hoje apenas alguns pedaços e três reproduções completas. Foto: Wikimedia

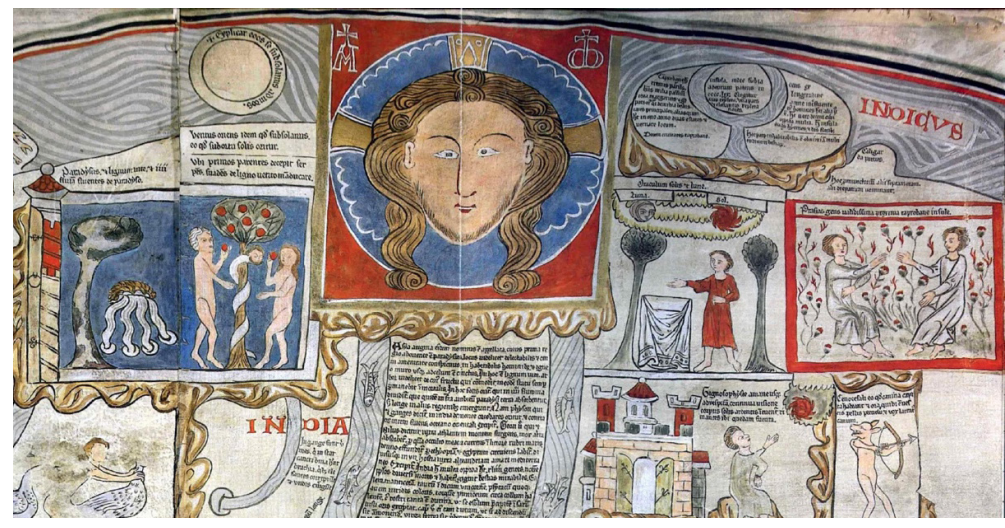

Figura 7- Detalhe Mapa Ebstorf. Representa o mundo como corpo de Cristo, neste detalhe é possível ver a cabeça de Cristo que fica no topo no mapa rodeado de mensagens teológicas.

Foto: Wikimedia 
legais de territórios, navegações comerciais, estratégias militares, administração do território rural, entre outros.

É difícil datar com precisão o período das transformações na cartografia no Renascimento, pois, como Woodward bem relembra, o período dessas transformações não acontece de forma homogênea na Europa. O autor, no entanto, consegue identificar fundamentais mudanças que acontecem entre os séculos XV e XVI, que concernem à relação do homem com os mapas.

Essas mudanças são organizadas pelo autor em três categorias: (1) Mudanças na relação interna da estrutura do mapa ou sintaxe gráfica; (2) Mudanças no relacionamento do mapa com sua fonte no mundo observado e (3) Mudança no relacionamento entre mapas e sociedade.

A primeira, mudanças na relação interna da estrutura do mapa ou sintaxe gráfica, está relacionada ao momento em que as obras de Ptolomeu passam a ser resgatadas e reestudadas. Passa-se a adotar o sistema de coordenadas terrestres, o que implica que o posicionamento de um lugar não é mais importante que outro. Há, portanto, coordenadas (ainda não como as de hoje) a serem seguidas, o que facilitava a inserção de lugares novos no mapa, sem ter que deformá-lo de seu desenho inicial.

A segunda, mudanças no relacionamento entre o mapa e sua fonte no mundo observado, se refere aos sistemas de códigos e legendas que passam a surgir nos mapas. O que antes era uma determinação imposta pelo cartógrafo, e que graficamente não explicava os códigos adotados, a partir deste momento passam a ser códigos explicados através de legendas e alguns símbolos são padronizados. Isso ocorre devido ao aumento de circulação de certos mapas; o que antes era consensual para uma minoria que dominava a arte dos mapas deve ser compartilhado com o público que passa a ter acesso aos mesmos documentos. Por isso, havia a necessidade de ampliar o entendimento gráfico dos documentos.

E a terceira e última categoria de mudança apontada por Woodward é a mudança no relacionamento entre mapas e sociedade, que surge com as possibilidades de impressão. As reproduções de mapas passam a ser impressas, o que leva à diminuição significativa de intervenções do copiador/escrivão, e a uma maior homogeneidade em reproduções de 
informações.

Vale ressaltar que essas significativas mudanças que aconteciam no Renascimento não eram apenas no mundo cartográfico, mas sim uma consequência de mudanças em um conjunto de frentes do conhecimento. Segundo Alfredo Bosi ${ }^{31}$ "...é um momento de busca fervorosa da unidade que rege microcosmo e macrocosmo" (1993, p. 74), momento esse também marcado por uma outra maneira de se pensar ciência, que é o método experimental. Galileu é considerado um dos fundadores da experimentação.

"O que caracteriza a atitude científica galileana - e também a atitude científica moderna - é a procura da natureza, de regularidade matematicamente expressáveis, as chamadas leis da natureza, e o método de certificar-se de sua verdade através da realização de experimentos" (MARICONDA, 2006, p. 268)

As experimentações incentivaram novas maneiras de mensurar e perceber as coisas. Galileu, por exemplo, dentre suas diversas contribuições, aperfeiçoou o telescópio e o utilizou pela primeira vez para observações astronômicas. A significação do instrumento, o telescópio, vai muito além da aproximação de objetos estelares, mas como Marilena Chauí desenvolve em seu ensaio Janela da Alma, Espelho do Mundo:

“O telescópio tem a intrigante propriedade de fazer ver o que não existe (porque o olho nu não o vê), e de deixar de ver o que existe (porque o olho nu o vê), isto é, modifica distâncias, luminosidades, movimentos, grandezas.” (CHAUí, 1993, p. 55)

Foram contribuições como esta que foram determinantes para formar uma outra maneira de olhar o mundo e, como consequência, outros modelos de mundo. Surge uma outra relação entre a techné $e^{32}$ e a episteme ${ }^{33}$, ou seja, a aproximação do homem com a natureza se altera, e

\footnotetext{
31 Alfredo Bosi é um professor universitário, crítico e historiador de literatura brasileira, membro da Academia Brasileira de Letras

32 Techné (Técnica): corresponde ao conhecimento prático, ao saber fazer, às artes e às técnicas em geral. (MARICONDA,2006:273)

33 Episteme (ciência): corresponde ao mais elevado grau de conhecimento certo, necessário e demonstrável, ou seja, ciência em seu sentido estrito. (MARICONDA,2006:273)
} 
a noção de tecnologia começa a ser formada. O instrumento passa a ser a materialização do pensamento, uma criação de teorias materializadas.

"O telescópio, objeto tecnológico (mais do que simplesmente técnico), é a razão corrigindo o olhar, ensinando-o a ver, liberando-o de si mesmo ao mostrar-lhe que a umidade dos olhos, refletindo e refratando luz, modifica os raios luminosos, deforma os objetos e incapacita o olho para boa visão [...] O essencial no telescópio não é que aproxime ou aumente objetos, mas que transforme o próprio ato de ver, fazendo-o resultar do ato de conhecer, depositado no instrumento [...] separando os olhos da visão " (CHAUÍ, 1993, p. 55)

Assim como o telescópio, a perspectiva linear também permitiu uma visualização que aproximou o observador ao observado. Para Tally “[...] o desenvolvimento da perspectiva linear, o qual não só permitia uma representação mais precisa nas artes visuais, mas também ocasionou um completo re-imaginar do espaço e das relações espaciais humanas." ${ }^{34}$ (2013, p. 17, tradução nossa)

A representação do espaço passa, portanto, a ser geométrica (calculável/quantificado), e o sujeito se torna cada vez mais implicado em representações espaciais. Ainda que os mapas/ atlas da época fossem sempre vistas aéreas, para Woodward, "as implicações da visão geométrica da cartografia de centralizar, enquadrar e orientar os mapas era de grande alcance na percepção do público em todo o mundo"35 (2007, p. 23, tradução nossa). Conjuntamente a essa sensível alteração espacial, nas representações cartográficas, o geógrafo atenta para uma outra significativa mudança:

"Uma distinta separação nos mapas de informações históricas e contemporâneas ocorreu no Renascimento, favorecendo a ideia de que as

\footnotetext{
34 " [...] the development of linear perspective, which not only enable more 'accurate' pictorial representations in the visual arts but also occasioned a wholesale re-imagining of space and of human spatial relations" (TALLY, 2013, p.17)

35 "The implications of this geometric view of cartography for the centering, framing and orientation of maps were far reaching in the public perception throughout the world" (WOODWARD, 2007, p. 23)
} 
coisas representadas no mapa deveriam todas ser de mesma temporalidade. [...] reconhecendo a necessidade de compilar mapas com as informações mais atualizadas possíveis." ${ }^{36}$ (WOODWARD, 2007,p. 23, traduçãonossa)

Ainda para Woodward, diante dessas mudanças que permearam o conhecimento durante a segunda metade do Período Renascentista, a ciência conquista espaço na produção intelectual (2007, p. 22). E, para Harley,

“O primeiro grupo de normas cartográficas, consequentemente, pode ser definido em termos de uma epistemologia científica. Ao menos desde o século XVII, os topógrafos e os leitores de mapas europeus foram promovendo um modelo científico padrão de conhecimento." ${ }^{37}$ (HARLEY, 2005, p. 189, tradução nossa)

Segundo o geógrafo John P. Snyder, desde o final do século XV em diante, com o início das grandes navegações “[...] um método efetivo de mapear com latitude e longitude já era entendido em círculos escolares"38 (2007, p. 380, tradução nossa) e, por mais que houvesse familiaridade com esses conceitos, a preocupação era mais de representação matemática do que de localizar e encontrar lugares.

Ao longo do século XVI, ápice das grandes explorações marítimas, foram desenvolvidos dois tipos de mapas: 'Carta Marina' e 'Cosmographia'. Snyder, em seu ensaio Map Projections in the Renaissance, explica que o primeiro tipo aparenta uma carta náutica, e o segundo parece um mapa do mundo típico de livro didático. Esses dois tipos de mapas eram publicados e lidos aos pares (Figura 8).

36 " [...] a distinct separation on maps of historical from contemporary information took place in the renaissance, favoring the idea that things represented in the map space should all have the same 'tense'. [...] recognizing the need to compile maps with the most up-to-date information possible." (WOODWARD,2007, p. 23)

37 "El primer grupo de normas cartográficas, por lo tanto, puede ser definido en términos de una epistemología científica. Por lo menos desde el siglo XVII, los topógrafos y los lectores de mapas europeos han ido promoviendo un modelo científico estándar de conocimiento.” (HARLEY,2005:189)

38 “(..) an effective method of mapping it with latitude and longitude was already understood in scholarly circles"(SNYDER, 2007:380) 


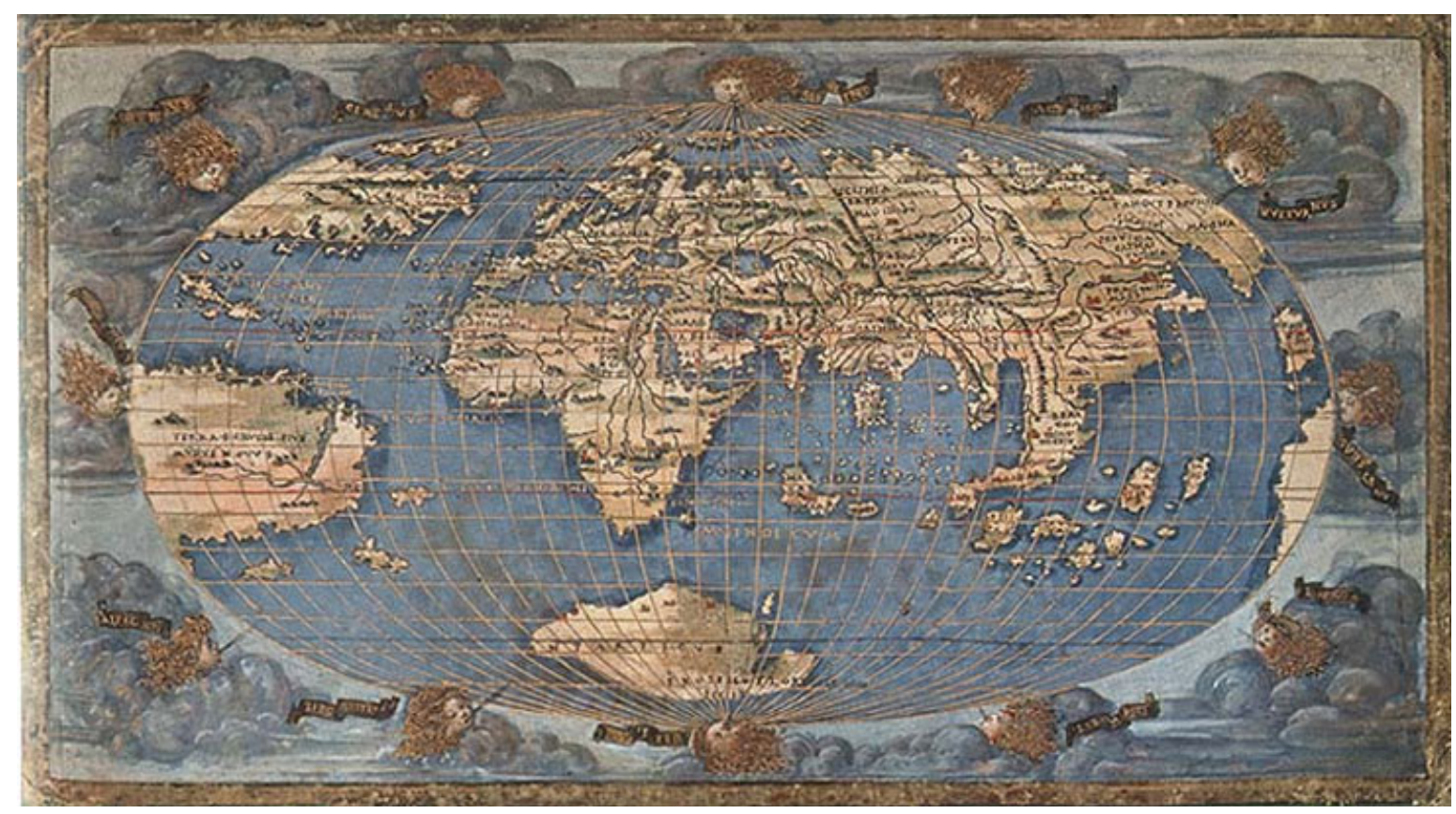

Figura 8- Mapa do Mundo (Carta Marina) por Francesco Rosseli (1508).Apesar da modesta dimensão $(20,5 \times 34,5 \mathrm{~cm})$ é um dos primeiros mapas a projetar todos os $360^{\circ}$ de longitude e $180^{\circ}$ de latitude da esfera terrestre em um plano. Fonte: Wikimedia

O trabalho com esses dois tipos de mapas foi mais tarde evidente nos trabalhos revisitados de Ptolomeu. E Snyder ressalta que a sua combinação desses dois tipos de mapas de forma elegante se dá na Projeção Mercator em 1569.

É por volta dos anos 1500 que surge um importante estudioso de origem holandesa, Gerard Mercator (1512-1594) responsável por inúmeros estudos na geografia, deixou uma herança importante para a história e desenvolvimento da cartografia: a Projeção Mercator ${ }^{39}$. O mapamúndi de Mercator, diferentemente das indicações feitas por Ptolomeu, não fazia uso de uma malha de coordenadas aleatórias, mas sim de coordenadas e uma malha totalmente matematizada partindo do princípio de que o formato da Terra era esférico (Figura 9). A projeção tinha como

39 Essa projeção, desenvolvida por Gerardus Mercator, apresentou uma solução matemática para representação do globo terrestre para uma superfície plana. A conformidade e a representação das linhas de rumo por segmentos de reta fazem com que esta projeção seja particularmente apropriada para apoiar a navegação marítima: rumos e azimutes são medidos diretamente na carta, através de transferidores ou das rosas-dos-ventos aí impressas, e as correspondentes direções podem facilmente ser transferidas para outros locais da carta, utilizando um par de esquadros de navegação. 


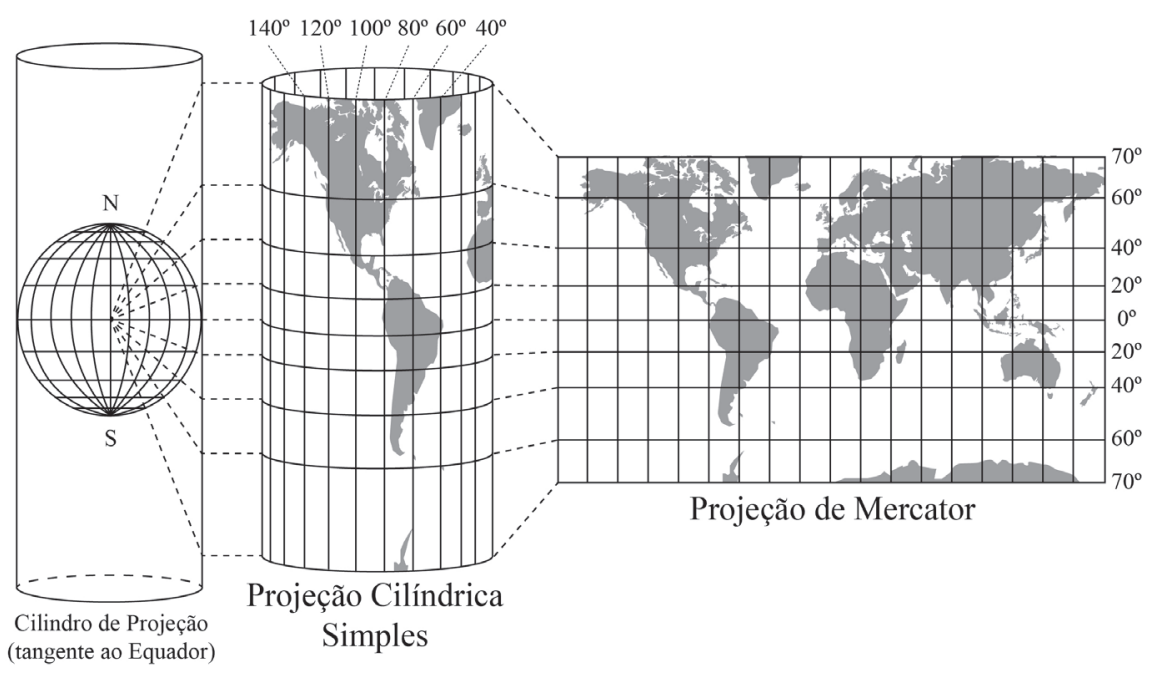

Figura 9- Projeção cilíndrica em que todos os meridianos são linhas retas perpendiculares ao Equador e às suas linhas de latitude. Entretanto, à medida que se dirige aos polos, as distorções aumentam drasticamente. Essa geometria faz com que a superfície da Terra se torne deformada na direção leste-oeste e quanto maior ou menor for a latitude. É acompanhada por idêntica deformação na direção norte-sul, o que a torna infinita nos polos, impedindo a sua representação. Fonte: Paula Pacheco

finalidade a navegação. Os meridianos e paralelos passam a ser representados em linhas retas e se cortam em ângulos de $90^{\circ}$, característica essa que facilita planejamentos de percursos (Figura 10).

Monmonier diz, em seu livro How to Lie with maps, que a Projeção de Mercator "demonstra que o cartógrafo pode frequentemente criar uma projeção sob medida para servir a uma necessidade específica"40 (1991, p. 16, tradução nossa). A Projeção, elaborada no ano 1569, responde de forma eficiente às necessidades das navegações da época; no entanto, passa a ser adotada como uma projeção padrão do mundo para os mais diversos fins.

Apesar das inúmeras projeções já feitas, a de Mercator é amplamente utilizada justamente por sua resolução matemática entre longitudes e paralelos. Característica essa, somada aos cálculos, não isenta a representação de distorções. Cartógrafos posteriores a Mercator sempre identificaram as grandes distorções que a famosa projeção apresentava e, no ano de 1898, o 40 “...demonstrate the mapmaker often can tailor the projection to serve specific need.” (MONMONIER, 1991:16) 


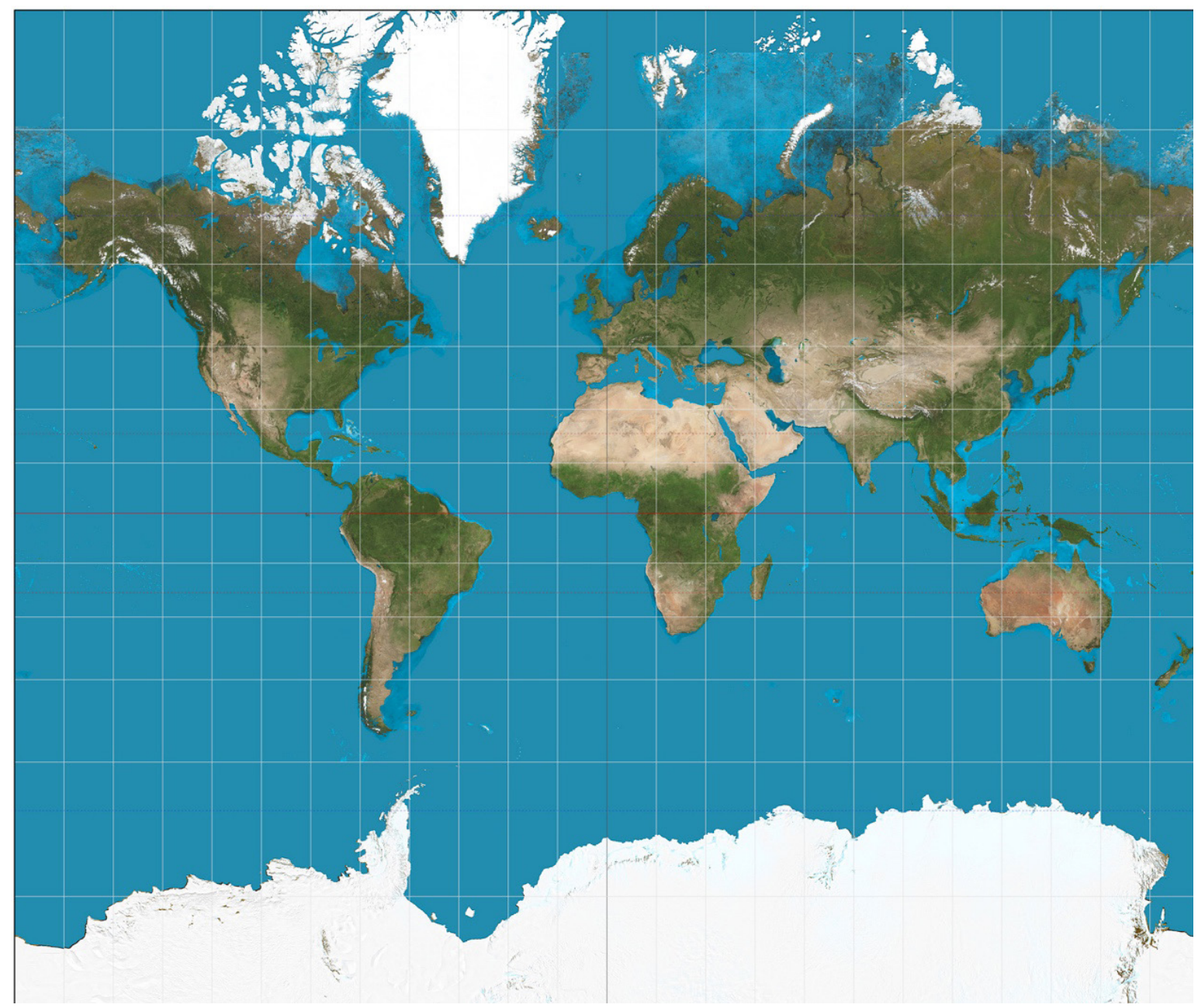

Figura 10- No século XVII esse modelo foi de extrema valia aos navegantes, pois permitia traçados retilíneos, planejamentos e cálculos mais claros e precisos de navegações. Fonte: Wikimedia

belga Van der Grinten propõe uma alternativa (Figura 11).

Em uma publicação de Snyder, Map Projections - A Working Manual (1987), o autor explica que esta projeção proposta por Van der Grinten foi inclusive adotada como mapa padrão da National Geographic Society desde 1922 até a década de 80, o que a tornou referência para muitos outros órgãos como o U.S. Department of Agriculture, por exemplo.

Snyder ainda explica que o diferencial da projeção de Van der Grinten é que incluiu uma construção gráfica e resolução matemática mais simplificada: 


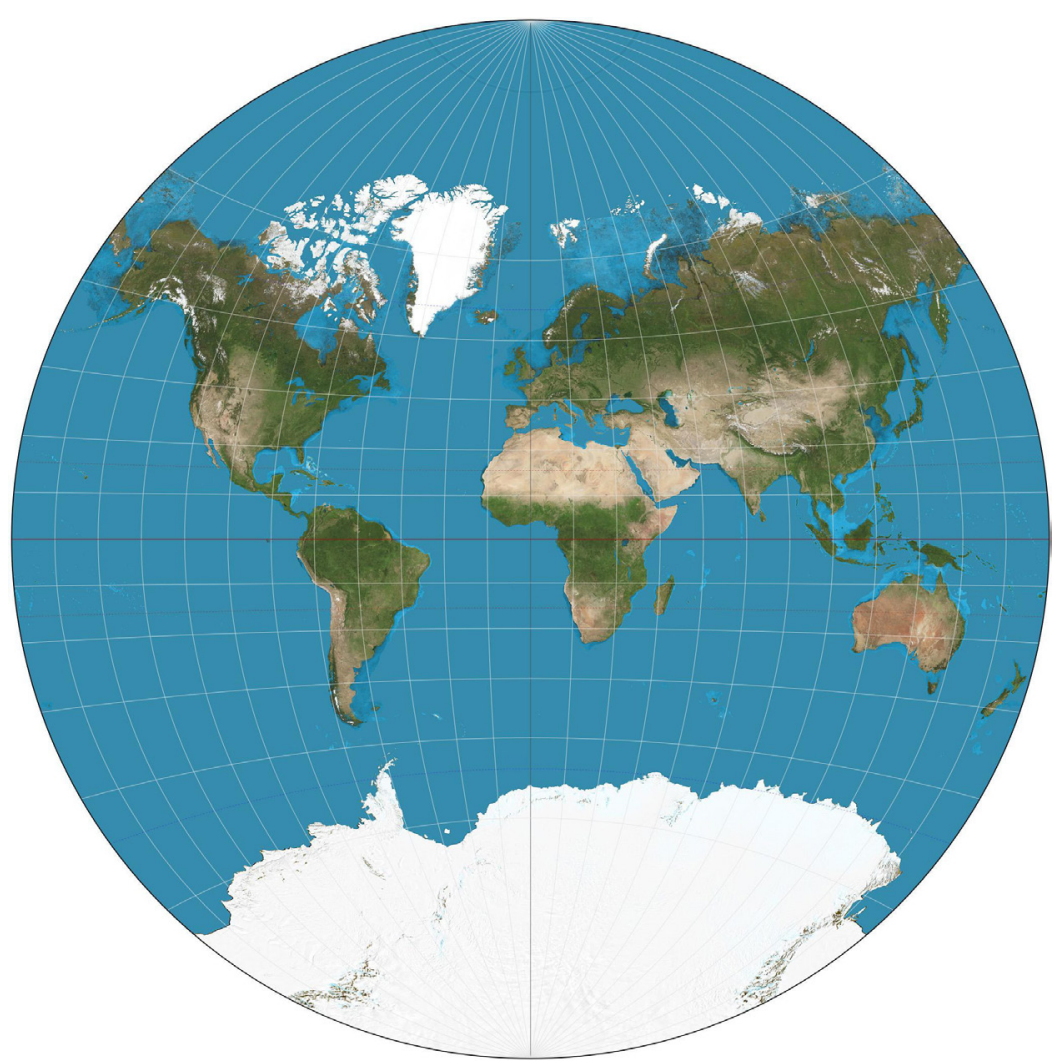

Figura 11- Projeção Van der Grinten (1898). O meridiano central e o Equador são linhas retas, enquanto os demais meridianos e paralelos são circulares. Fonte: Wikimedia

“Os meridianos são igualmente espaçados ao longo do Equador, mas o espaçamento entre os paralelos aumenta com a latitude; assim, os 75 paralelos são mostrados por volta da metade entre o Equador e os respectivos polos." (SNYDER, 1987, p. 239, tradução nossa)

O geógrafo J.B.Harley também ressalta que, nesse momento, a cartografia estava estabelecida como instrumento de representação de poder, mas também como forma distanciada e segura de experiência do mundo. Em seu artigo Descontructing the Maps, ele afirma:

"Desde o Renascimento a forma de exercer o poder mudou. Na América do Norte colonial, por exemplo, os europeus traçavam com facilidade linhas através dos territórios das nações índias sem mostrar nenhuma 
sensibilidade ante a realidade de sua identidade política. O mapa os permitia dizer: Isto é meu; estas são suas fronteiras. De maneira similar, em inumeráveis guerras desde o século XVI, foi fácil para os generais lutar batalhas com sinalizadores e marcas coloridas, ao invés de sensibilizaremse com a chacina no campo de batalha." ${ }^{41}$ (HARLEY, 2001, p. 167, tradução nossa)

Segundo o geógrafo Jeremy Crampton (2006) foi apenas ao final do século XIX e início do século XX que a cartografia passou a ser entendida como uma disciplina claramente científica. Essa nova maneira de se entender a cartografia possibilita uma aproximação a uma leitura mais crítica aos mapas.

Um exemplo representativo desta condição é a preocupação e a discussão por uma representação mais 'justa' e mais ampla que surge com força no âmbito da disciplina da Cartografia no período pós Primeira Guerra Mundial. Crampton, para ilustrar o surgimento dessa nova aproximação, cita o geógrafo Mark Jefferson, ${ }^{42}$ que trabalhou no Tratado de Paz de Versailles (1919), argumentando que:

"Todos mapas populacionais passados eram deficientes porque assumiam que lugares existiam naturalmente anteriormente ao ato de mapear, com fronteiras políticas preexistentes. O senso mais verdadeiro de lugar, no entanto, foi criado pelo próprio ato de mapear. Portanto, para Jefferson, mapas eram economia política aplicada e não eram menos políticos por serem aplicados." ${ }^{43}$ (CRAMPTON, KRYGIER, 2006, p. 23, tradução nossa)

\footnotetext{
41 "Since the Renaissance they have changed the way in which Power was exercised. In colonial North America, for example, it was easy for Europeans to draw lines across the territories of indian nations without sensing the reality of their political identity.The Map allowed them to say, "This is mine; these are the boundaries. Similarly, in innumerable wars since the sixteenth century it has been equally easy for the general to fight battles with colored pins and dividers rather than sensing the slaughter of the battlefield."(HARLEY, 2001, p. 167)

42 Mark Jefferson (1863-1949): Foi cartógrafo e geógrafo na Universidade de Eastern Michigan, Presidente do AAG em 1916 e cartógrafo chefe na Conferência de Paz em Paris (1919) onde trabalhou juntamente com Isaiah Bowman do American Geographical Society (1968) (CRAMPTON 2006, p. 23).

43 "All previous population maps (...) were deficient because they assumed that places existed naturally prior to the act of mapping, with preexisting political boundaries. A truer sense of place however was created by the act of mapping itself. For Jefferson therefore, maps were applied political economy and were no less political for being applied.” (CRAMPTON;KRYGIER, 2006, p. 23)
} 
Em 1967, Arno Peters apresenta outra projeção (Figura 12) distinta da até então dominante, a de Mercator. Segundo Seemann (2003), a justificativa e o discurso que acompanharam a apresentação feita por Peters vieram com fortes críticas à projeção Mercator, indicando-a como uma "projeção de mentalidade colonialista e racista, porque posicionava o equador abaixo da linha central do mapa e distorcia as áreas nas latitudes, aumentando a importância do Primeiro Mundo" (SEEMANN, 2003, p. 13). Peters ainda afirmava que buscava com sua projeção uma representação mais correta politicamente.

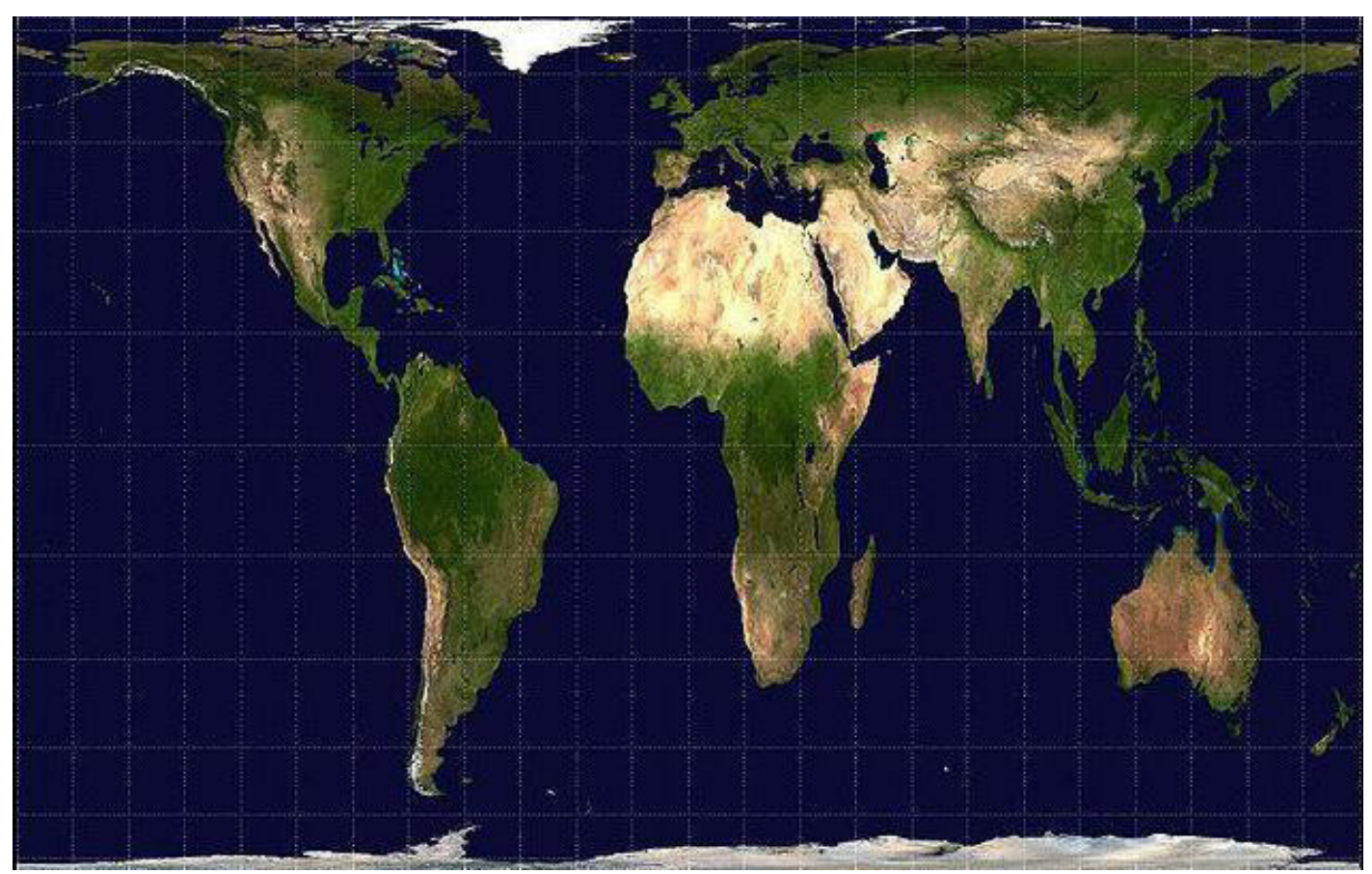

Figura 12 - Projeção de Arno Peters. Fonte: Wikimedia

A proposta do historiador Arno Peters causou uma fervorosa discussão nas publicações cartográficas. Seemann (2003) menciona que muitos foram os cartógrafos que condenaram a Projeção de Peters. As críticas contra a proposta de Peters foram de várias naturezas, desde Peters não possuir a formação de geógrafo, ter havido plágio, até imprecisões de cálculos.

"Em consequência, muitos cartógrafos partiram para uma análise mais detalhada do mapa de Peters e condenaram sua projeção, alegando 
várias 'irregularidades cartográficas', como a posição incorreta dos paralelos de grandeza real $\left(46^{\circ} 2^{\prime} \mathrm{N}\right.$ e $\mathrm{S}$ em vez de $\left.45^{\circ}\right)$, a nãoequivalência da projeção e, a acusação mais grave, o plágio de uma projeção elaborada pelo reverendo escocês James Gall, em 1855. As críticas voltaram-se exclusivamente aos critérios técnico-científicos sem levar em conta o fato de que a preocupação principal de Peters não era a precisão matemática (embora ele mesmo tenha se gabado disso), mas uma representação mais justa do mundo.” (SEEMANN, 2003, p. 13)

O fato é, que foram muitos os cartógrafos, matemáticos, inventores, entre outros, que dedicaram seus estudos para encontrar uma forma de representar o planeta em uma superfície plana. Fica evidente que não há uma maneira perfeita (sem distorções). Existem infinitas variantes possíveis, pois há que se considerar para qual finalidade será utilizado o mapa, a tecnologia disponível para fazê-lo e qual a área a ser representada. Vale atentar que, após a Projeção de Mercator, muitas foram as alternativas criadas para substituí-la; no entanto, sempre se manteve em todas elas uma preocupação de padronizar coordenadas, escalas e distâncias. O sistema cartesiano parece dominar o pensar dos mapas, parece ser a única garantia de 'precisão científica' possível.

Diante das várias alternativas de representação cartográfica, surge uma sequência de questionamentos sobre as decisões implícitas em uma prática. Muitas projeções são criticadas e discutidas. O geógrafo Mark Monmonier alerta em seu livro já mencionado que, por mais calculadas que sejam essas projeções, haverá sempre uma distorção:

"Projeções de mapas distorcem 5 relações geográficas: áreas, ângulos, formatos, distâncias e direções. Mesmo que algumas projeções preservem ângulos locais mas não áreas, outras preservam áreas e não ângulos locais." "44 (MONMONIER, 1991, p. 15, tradução nossa)

44 "Map projections distort five geographic relationships:areas, angles, gross shapes, distances, and directions. Although some projections preserve local angles but not areas, others preserve areas but not local angles." (MONMONIER,1991:15) 
O entendimento destas distorções é essencial para refletir sobre os limites representativos do mapa, e essa questão se torna um impulso inicial para uma aproximação crítica à disciplina.

\section{2_A ESFERA HIPERMAPEADA}

Duas imagens irromperam um novo olhar em relação à localização e à totalidade do território em escala planetária. Ambas imagens foram realizadas em missões espaciais e subsequentemente se tornaram imagens icônicas.

A primeira é um registro fotográfico do Planeta Terra que foi tirada no ano de 1968 pela missão Apollo 8. A foto AS8-14-2383, também conhecida como 'Earthrise' (Figura 13), mostra, em primeiro plano, uma parte da superfície lunar e a Terra aproximadamente a $5^{\circ}$ acima da linha do horizonte, boa parte dela com sombra.

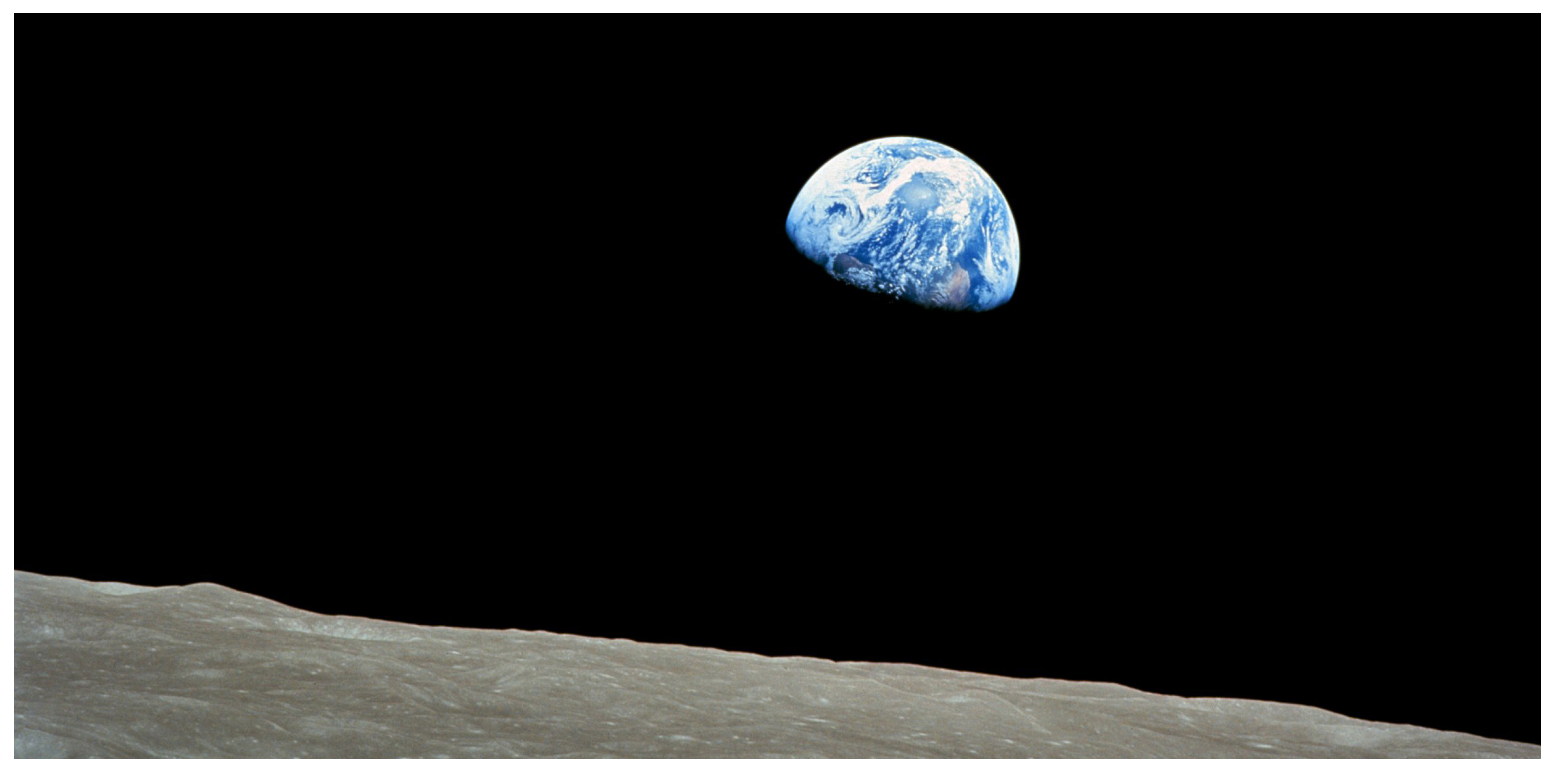

Figura 13 - Fotografia AS8-14-2383 (Earthrise) - 1968. Fonte: Wikimedia

A segunda fotografia foi tirada em 7 de dezembro de 1972, nomeada como AS17-14822727, também conhecida por simplesmente foto 22727 ou 'The Blue Marble' (Figura 14). A fotografia foi tirada na missão Apolo 17 a caminho da Lua. Nessa fotografia, mais nítida que 
a primeira, é possível ver o planeta sem sombra, podendo identificar claramente a extensão do Mar Mediterrâneo até a Antártica, incluindo o Continente Africano e parte da Península Arábica. A 'Earthrise’ possui um caráter diferente pelo fato de possuir referências. Em outras palavras, o fato de aparecer um pedaço da Lua contextualiza a posição do fotógrafo, e também, devido à Terra estar parcialmente iluminada, há uma indicação da ação da luz solar. Apesar do Sol não aparecer diretamente na imagem, ele é um elemento do entorno contextualizado de forma indireta. São esses detalhes que tornam a foto palpável e contextualizada; remete ao observador toda uma narrativa sobre a imagem. Já a fotografia posterior, 'The Blue Marble', apresenta a Terra flutuando no meio do vazio, sem qualquer perspectiva ou contextualização indireta do entorno, o que confere à foto um caráter quase que abstrato. O diâmetro da esfera segue a linha do Trópico de Capricórnio e não a da Linha do Equador, ou seja, o planeta não está totalmente centralizado. Essa descentralização, segundo Cosgrove, “ [...] parece apropriada para uma imagem cuja popularidade floresce desde 1972, que coincide com o amplo impulso político e cultural de imaginar e articular um globo sem centros privilegiados e periferias subordinadas [...]" ${ }^{45}(2001$, p. 261, tradução nossa).

O principal e primeiro impacto que essas imagens causaram foi uma visão do mundo sem fronteiras, o entendimento de 'mundo único'. Cosgrove cita em seu livro Apollo’s eyes (2001) a fala do comandante da Missão Apollo 8, Frank Borman, testemunhando pela primeira vez o horizonte lunar.

"Quando finalmente você está na Lua olhando para a Terra, todas aquelas diferenças e traços nacionalistas vão simplesmente se misturar e você entenderá um conceito de que talvez isso seja mesmo um único mundo e por que diabos não conseguimos aprender a viver juntos como pessoas decentes?"46 (2001, p. 258, tradução nossa)

\footnotetext{
45 “ (...) seems appropriate for an image whose burgeoning popularity since 1972 has coincided with broader political and cultural thrust to imagine and articulate a globe without a privileged center and subordinated periphephery (...)" (COSGROVE; 2001:261)

46 "When you're finally up at the moon looking back at the Earth, all those diferences and nationalistic traits are pretty well going to blend and you're going to get a concept that maybe this is really one world and why the hell can't we learn to live together like decente people?" Citação de Frank Borman em (COSGROVE, 2001:258)
} 


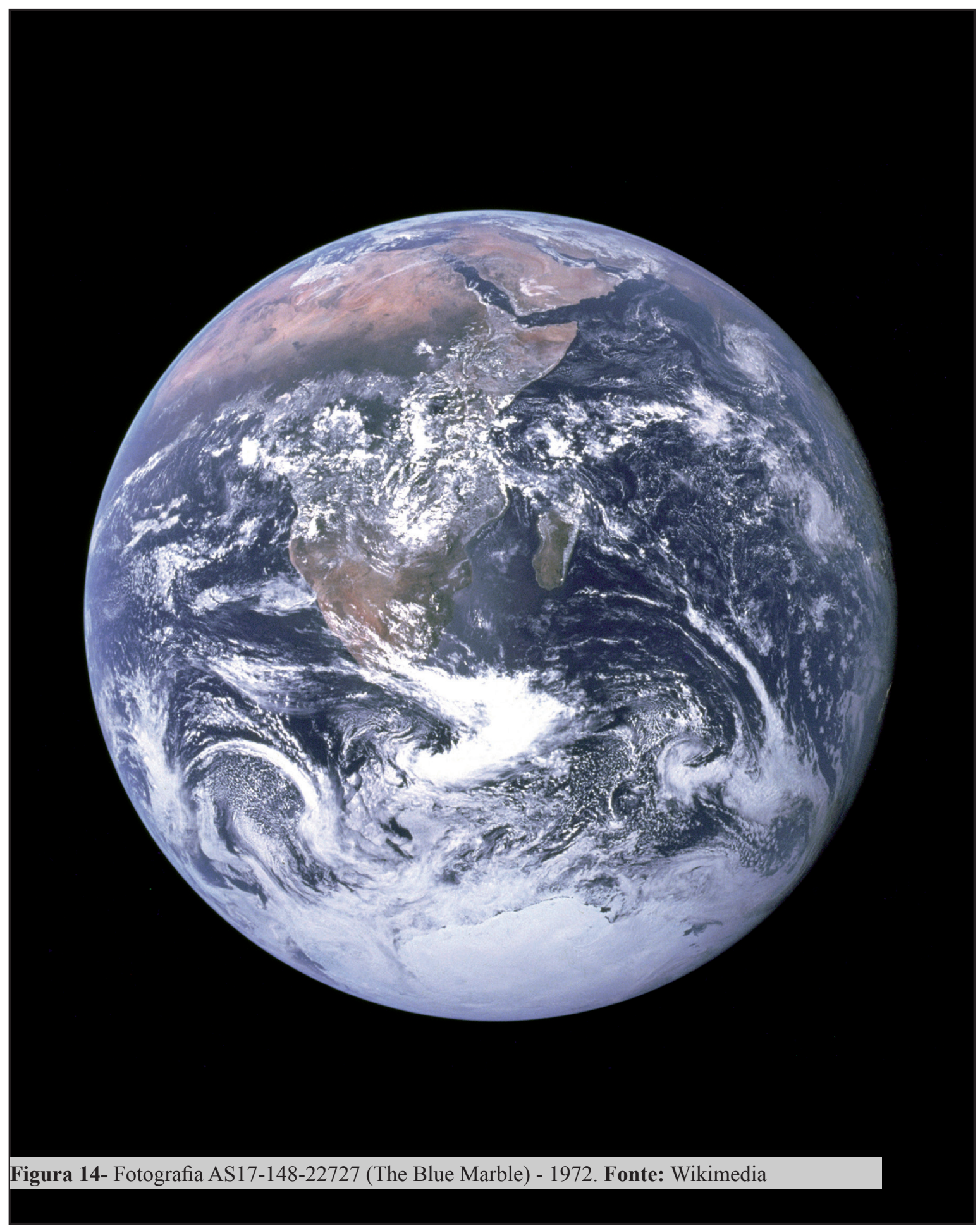


Esse conceito de um 'mundo único' pode ser interpretado, segundo o autor, de inúmeras maneiras: pode ser uma leitura mais humanitária de união e irmandade, ou um gesto imperialista de dominação, ou como um apagamento totalizante artificial e abstrato das verdadeiras diferenças, ou até mesmo como base de um novo movimento político global para os direitos humanos e/ou de responsabilidade planetária.

O fato é que, apesar das várias interpretações possíveis desse conceito, Cosgrove afirma que as duas imagens "[...] se tornaram a imagem do globo, simultaneamente 'verdadeiras' representações e espaços virtuais" ${ }^{47}$ (2001, p. 257, tradução nossa). Estavam lá as novas formas que dominariam o imaginário humano. Em especial a foto 22727, fotografia em que a Terra aparece por inteiro e que, por não possuir sombra ou qualquer perspectiva, retira o observador da imagem.

Kurgan menciona em seu livro Close up at distance (2013) um momento importante em que a fotografia passa a ser produzida não mais por apenas um clique, mas por milhares deles. Em 2002, a NASA produziu um novo par de imagens intitulado também como 'The Blue Marble'; no entanto, dessa vez as imagens são uma montagem de imagens de satélites tiradas ao longo de um período de quatro meses. Com a resolução de $1 \mathrm{~km}^{2}$ por pixel. E, em 2005, a NASA refez as duas imagens com uma resolução de $500 \mathrm{~m}^{2}$ por pixel (Figura 15). Observando-se essa imagem gerada em 2005, fica evidente como o seugrau de abstração aumenta, ganha um caráter mais plastificado e artificial, uma vez que é resultado de uma complexa montagem de fotografias. Fotos essas separadas de acordo com alguns critérios (por exemplo sem interferência de nuvens) e, posteriormente, no formato de montagem submetida a tratamentos de imagem (limpeza de 'ruídos' e 'imperfeições'). São globos construídos assim que passam a ser utilizados nos grandes programas locativos desde então.

O estudioso em cultura digital, Jason Farman, exemplifica em seu artigo Mapping the digital empire (2010) esse momento com o lançamento do Google Earth em 2005. O autor questiona a 'neutralidade' da ferramenta e relembra sua origem de uso militar. 


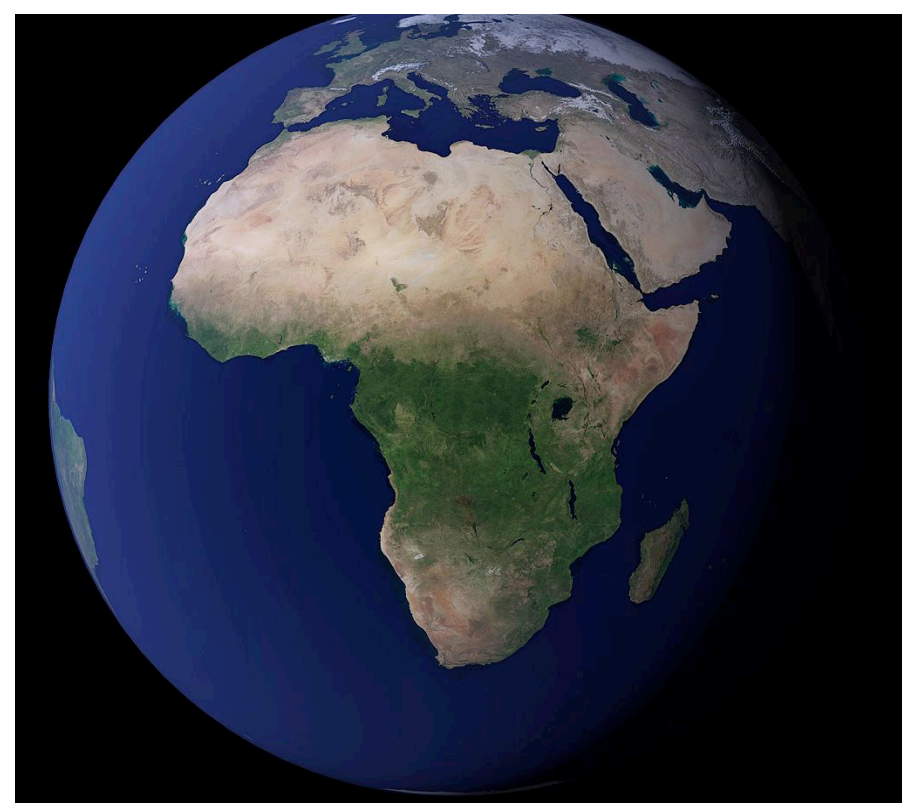

Figura 15 - 'The Blue Marble: The Next Generation "- 2005 Montagem de imagens de satélites tiradas em observações mensais em dias sem nuvens, em uma resolução de $500 \mathrm{~m}^{2}$ por pixel. Fonte: Wikimedia

Fotos aéreas de satélites, antes de serem disponibilizadas ao público, serviam como ferramentas militares de controle e vigilância. Essas imagens serviram muito a grandes potências mundiais na época da Guerra Fria, momento em que a palavra 'satélite' era imediatamente associada com uma função militar - desde o imaginário da ficção científica até as realidades políticas da época.

Para vários dos principais estudiosos da cartografia ${ }^{48}$, apesar de particularidades e diferentes facetas em seus argumentos, todos de maneira geral argumentam que a subjetividade está presente na produção e na leitura das representações mapeadas. Mas, desvincular o entendimento de neutralidade das fotos de satélite não é um exercício fácil e imediato especialmente no senso do usuário comum.

'Quem' realiza uma foto de satélite é outra questão que fica encoberta. Remontando à cientificização da cartografia, quando a arte de cartografar manualmente perdeu seu espaço e, como Harley aborda em seu artigo Text and Contexts in the Interpretation of Early Maps,

48 os principais serão abordados no próximo item do capítulo 
na mudança da era do manuscrito para a época da impressão, acentua-se a divisão do trabalho de produção dos mapas; os mapas passam a ter sua reprodução aumentada e a ideia de uma única autoria sob o mapa se torna menos óbvia. Essa perda do senso de autoria, segundo Jason Farman, se torna mais acentuada com o advento da fotografia; enquanto fotografias comuns são associadas a fotógrafos, as fotos de satélite são associadas a máquinas, sem a vinculação a pessoas ou organizações diretamente relacionadas, que são aquelas que direcionam, editam e compilam as imagens dos satélites.

“Acredita-se que essas representações são objetivas; que são simplesmente imagens da realidade fora do domínio da interpretação cultural. O problema em posicionar GIS ${ }^{49}$ como um software que simplesmente junta dados empíricos e os apresenta como fatos diz respeito àquela 'objetividade científica' que está tipicamente situada e privilegia aqueles no poder." ${ }_{50}$ (FARMAN; 2010, p. 8, tradução nossa)

A imersão desta nova maneira de se mapear o mundo através de satélites com a tecnologia GIS e GPS marca a chegada da geolocalização. São essas tecnologias que passam a associar a localidade de um objeto/sujeito com coordenadas geográficas precisas e em tempo real. Através de uma rede de satélites e estações em terra, dados e informações geolocativos são processados - dados informacionais passam a ser associados a coordenadas.

Software como Google Earth (Figura 16) se tornam fonte de busca e consulta de localizações. Passam a apresentar a localização desejada associada com uma série de dados, coordenadas e os mais diversos layers informacionais. Como se vê na figura 16, a interface deixa de ser simplesmente composta pela imagem do local, mas por um conjunto das mais diferentes pastas de acessos, buscas e comandos que podem ser atualizados em tempo real além da imagem em si.

\footnotetext{
49 GIS: Geographic Information System.
}

50 " These representations are believed to be objective; they are simply images of reality and outside the realm of cultural interpretation. The problem with positioning GIS as software that simply gathers empirical data and presents it as facts is that such 'scientific objectivity' is typically situated and privileges those in power." (FARMAN;2010, p.8) 


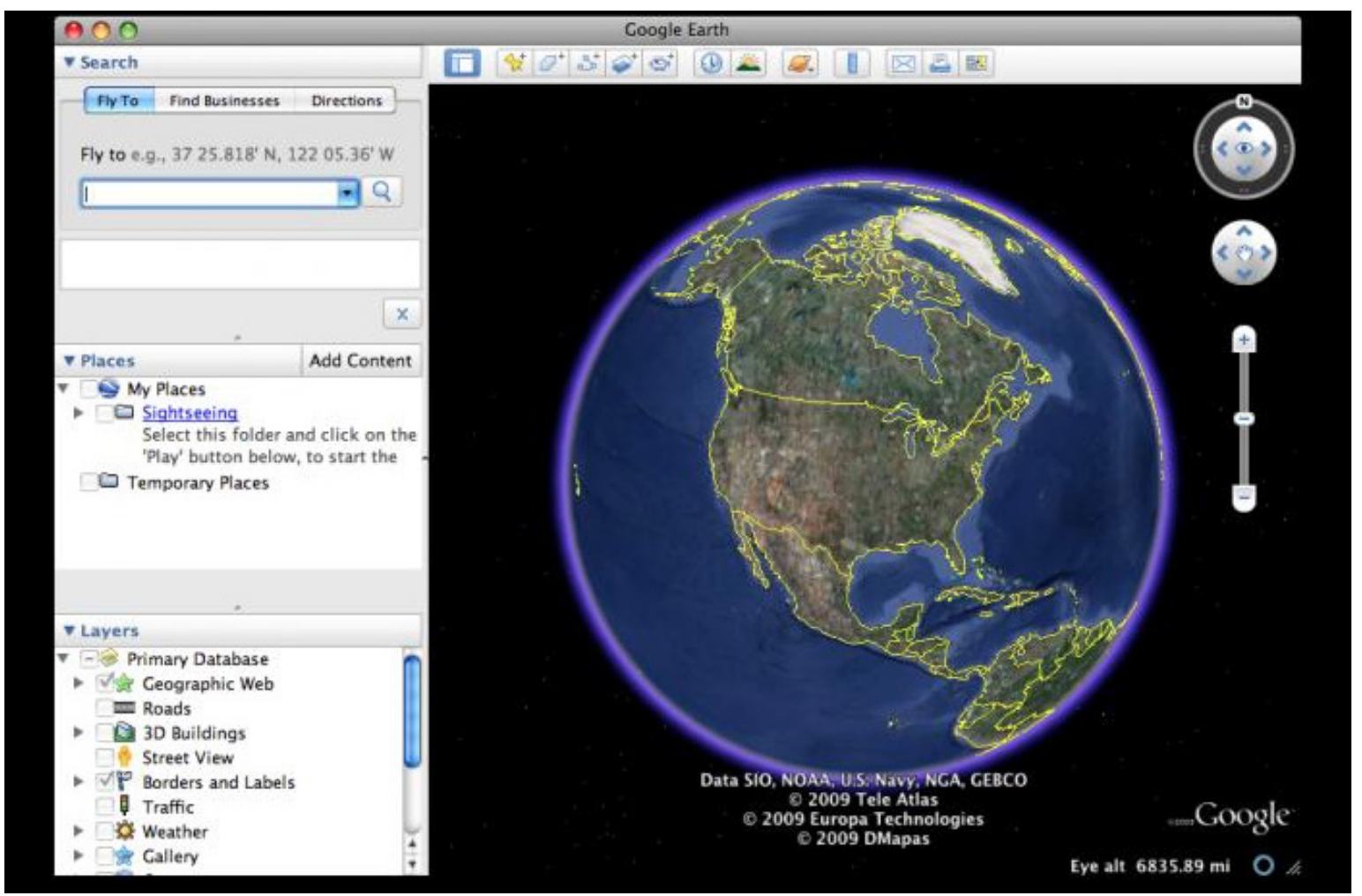

Figura 16: Interface do Google Earth - 2009 Fonte: Google

Google Earth permite, desde sua origem, uma interação complexa com informações, possibilitando desde um cálculo de rotas de um ponto $\mathrm{A}$ ao ponto $\mathrm{B}$, vistas panorâmicas de de cidades ao nível do olho humano e até mesmo um 'voo' por paisagens grandiosas. Hoje, essas ferramentas se sofisticaram e são milhares as informações possíveis de serem extraídas.

Ainda que o programa se apresente aberto para input/correções feitas por usuários e participantes em fóruns (ex: Google Earth Community), a sua 'neutralidade' é colocada em cheque por Farman. O autor, em seu artigo Mapping the Digital Empire, relata um caso ocorrido em julho 2007 em que um membro Esloveno do Google Earth Community notifica ao Google que a fronteira entre a Eslovênia e a Itália estava incorreta na cidade de Nova Gorica; explicitava ainda que a cidade deveria pertencer à Eslovênia e não mais à Itália. Esta notificação recebeu uma alta repercussão, outros membros começaram a postar, 
subsequentemente, imagens de mapas e notícias que validavam a notificação do Esloveno. A Google realizou a alteração nas imagens; no entanto, mesmo com a alteração na imagem da fronteira da cidade, o local continuou com a identificação e outras informações como 'Nova Gorica- Italy'. Ou seja, até que ponto realmente a interação dos usuários é efetiva? Como e sob quais critérios a Google decide a pertinência de cada decisão de representação?

Apesar de levantar essas questões, Farman mostra-se otimista ainda com a ferramenta. Para ele, ainda é possível levantar debates e questionamentos, como também relata no mesmo artigo um outro caso. Desta vez, sobre um usuário do Google Earth Community ter postado sob a cidade de Lhasa - Tibet a seguinte frase: 'No Human Rights Here'. Postagem essa que levantou uma profunda discussão sobre as violações dos direitos humanos cometidas na região pelo governo chinês na região.

Com o advento da disseminação das tecnologias móveis e pessoais, acontece uma transição significativa desse tipo de experiência de mapeamento que não só passa a ser possível de ser feita em movimento na palma de nossas mãos, mas também com a qual acontece uma troca de informação e dados em duas vias. Não só o usuário recebe as informações, mas também gera e fornece novas informações geolocativas. Sobre isso André Lemos afirma:

"Desta forma, os lugares/objetos passam a dialogar com dispositivos informacionais, enviando, coletando e processando dados a partir de uma relação estreita entre informação digital, localização e artefatos digitais móveis" (LEMOS, 2007, p. 2)

Farman, em seu livro Mobile Interface Theory (2012), ao tratar desses artefatos digitais móveis, ou melhor - mídias locativas - destaca como essa tecnologia pervade "a produção do espaço e os corpos que os habitam" $(2012$, p. 4) e a complexidade que gera na percepção do mundo com a mediação tecnológica:

"Das tecnologias com serviços locativos ao interesse renovado no papel de proximidade em interações sociais online, a especificidade de lugar 
ganhou um novo embasamento no imaginário cultural e acadêmico. Paisagens, pode-se dizer, se tornaram interfaces informacionais assim como a interface gráfica da tela de um computador." ${ }_{51}$ (FARMAN, 2012, p. 43, tradução nossa)

O autor aborda em seu livro como a mídia locativa se tornou uma mediação importante do sujeito com o seu meio: "a interface que serve como o nexo dessas interações complexas é fundamental para a produção de espaço incorporado em meios locativos." ${ }^{52}$ (2012, p. 61, tradução nossa). Ou seja, a experiência do usuário com o meio se dá com a interação com essas mídias locativas ou pelo acesso de informações em tempo real advindas das mais diversas fontes de usuários e bancos de dados. Nesse sentido, November, Hübner e Latour (2010, p. 595, tradução nossa) também entendem que "a representação do mapa não mais nos atinge como uma representação de 'lá fora', mas sim como um painel de controle de uma interface calculada que permite você localizar com precisão sucessivas indicações enquanto se move pelo mundo". ${ }^{53}$

São essas mediações digitais e a quantidade de dados que possibilitam que atualmente "localizar-se" ultrapasse a relação de posicionamento físico em um território. Localizar-se passa a englobar posições econômicas, sociais e políticas, dentre outras. Uma coordenada geográfica pode implicitamente se desdobrar em inúmeras outras informações, chegar inclusive a classificar o estilo de vida do sujeito e prever suas ações.

Apesar de todas essas transformações atreladas ao desenvolvimento tecnológico acontecerem de forma relativamente rápida, a aceitação por parte dos geógrafos não foi tão fácil no início. Na disciplina da cartografia, estudos e pesquisas passam a questionar, pensar e refletir para além da representação dos mapas, em direção às tecnologias que os sustentam; essas

51 "From location-aware technologies to renewed interest in the role of proximity in online social interactions, site-specificity has gained a new foothold in the culturaland scholarly imaginary. Landscapes, it can be said, have become information interfaces moch like the graphical user interface of a computer screen." (FARMAN;2012:43)

52 "The interface that serves as the nexus of these complex interactions is foundational for the production of embodied space in locative media" (FARMAN,2012, p. 61)

53 "[...] maps now strike not as what represent a world 'out there' but as the dashboards of calculation interface that allows you to pinpoint successive signpoints while you move through the world." (NOVEMBER; HÜBNER; LATOUR; 2009, p. 595). 
reflexões críticas adentram a implementação digital dos mapas, em especial na difusão da 'Geographic Information System” (GIS).

Segundo John Pickles, em seu texto Representations in an Eletronic age: Geography, GIS and Democracy (2008), é possível encontrar em literaturas diversas definições de GIS como sistema de manipulação e representação de informação espacial, sobre o qual, segundo o autor, deve-se ter um posicionamento crítico.

Em 1988, o artigo The Intellectual Core, que tratava sobre a disciplina da Geografia, já registrava a preocupação de muitos geógrafos acadêmicos sobre a emergência e profusão da tecnologia GIS. Terry Jordan, autor do artigo e também presidente da AAG (American Association of Geographers), se referia ao GIS como uma atividade não-intelectual que colocava em cheque o papel dos cartógrafos. Pois o autor se preocupava como o GIS alteraria as especialidades tradicionais da geografia, como, por exemplo, a geografia regional, geografia cultural, geografia histórica, dentre outras.

A partir de então, uma questão central passou a ser entender os limites da Cartografia. Tão logo o GIS passa a ser aceito no meio acadêmico, há o encontro anual ${ }^{54}$ da AAG contando com sessões como 'Ética na Cartografia' e 'Espaço, Poder e Representação: Ação Social e a Dialética Sócio-espacial'. Outros eventos científicos focaram igualmente na discussão do GIS na cartografia ao longo da década de 90. Mas um evento foi especial, segundo Crampton (2010), que aconteceu em Friday Harbor (Novembro de 1993) e, apesar de não ter Anais, resultou em uma série de produções em periódicos tempos depois. Em relato sobre o congresso de Friday Harbor, o estudioso John Pickles resumiu quatro principais pontos de pensamento que surgiram nas discussões que representavam o GIS crítico:

1. Contribuir para uma teoria de GIS que não o assuma como técnico e nem instrumental, mas que o localize como objeto, um conjunto de instituições, discursos e práticas que possuem efeitos sociais e disciplinares; 
2. Mostrar como esses efeitos disciplinares e sociais operam;

3. Forçar os limites do GIS, suas condições desconhecidas e consequências não intencionais de desenvolvimento e prática (por exemplo: influências corporativas, premissas epistemológicas e o entendimento das aplicações apropriadas)

4. Questionar se o GIS poderia ser diferente ou de que maneira poderia ser modificado para o uso futuro.

Os pontos assinalados pelo autor indicam quais pensamentos orientam um pensamento crítico em relação ao GIS, o que, de certa maneira, ordena e define questionamentos pertinentes aos geógrafos. Esse período, de meados dos anos 80 e década de 90, em resumo, não foi apenas marcado por reflexões críticas em relação ao GIS, mas à disciplina da Cartografia como um todo.

\section{3_DESCONSTRUINDO A NEUTRALIDADE DOS MAPAS}

Um dos grandes esforços neste trabalho é considerar uma visão crítica do tema central da pesquisa. No entanto, creio que seja importante esclarecer o que neste trabalho entende-se por crítica. Para tanto, segue uma citação do pensador Michel Foucault:

\footnotetext{
"A crítica não consiste em dizer que coisas não estão boas do jeito que estão. Consiste em ver sob que tipo de premissas, de noções familiares, de maneiras estabelecidas e não examinadas de pensar as práticas aceitas são baseadas" ${ }_{55}$ (FOUCAULT, 2000, p. 456, tradução nossa)
}

Para iniciar um entendimento crítico acerca das cartografias, muitas das questões levantadas por geógrafos como Harley e Woodward se tornam fundamentais. Retomaremos, portanto, a

\footnotetext{
55 "A critique does not consist in saying things aren't good the way they are. It consists in seeing on what type of assumptions, of familiar notions, of stablished, unexamined ways of thinking the accepted practices are based" (FOUCAULT, 2000:456)
} 
não neutralidade dos mapas, já tratada especificamente na relação direta com o uso dos meios técnicos em item anterior. Harley em seu artigo Desconstructing Maps (1989), apresenta pela primeira vez o mapa como uma construção social, ou seja, aponta que aspectos como contexto temporal, autoria, financiamento, o que revela e omite, são os que garantem uma leitura mais precisa da informação representada. Aspectos que mostram que ler apenas o que está representado não é o suficiente para uma interpretação mais aprofundada - posição que vai ao encontro com o que Foucault propõe sobre o pensar crítico:

"Crítica consiste em descobrir aquele pensamento e tentar mudá-lo: Mostrando que coisas não são tão óbvias como pessoas acreditam que são, fazendo que coisas que são subestimadas não sejam mais subestimadas. Fazer uma crítica é tornar mais difícil esses atos, que não são fáceis" ${ }^{56}$ (FOUCAULT, 2000, p. 456, tradução nossa)

Há, portanto, uma transformação significativa na maneira de se interpretar os mapas. Como já foi discorrido no início deste capítulo, a cartografia passa por avanços em termos de precisão e funcionalidade ao longo da história. Com a cientifização dos mapas, passa a dominar o senso comum que os toma como representações verdadeiras e únicas de um território, pois seguem normas, cálculos e simbologias específicas. Paralelamente, elimina-se a presença artística, e os mapas ganham um caráter de representação muito mais funcional.

Nas décadas finais do século XX, introduz-se uma visão crítica sobre o assunto, percebendose que nem o usuário, nem o cartógrafo possuíam a neutralidade necessária para garantir essa veracidade, que se supunha existir na representação cartográfica. Foi Harley que, segundo J. Seemann (2003, p. 14), incentivou "uma mudança epistemológica na maneira de interpretar a natureza da Cartografia". Harley em seu artigo Desconstructing Maps ${ }^{57}$ (1989), afirma a importância de uma postura mais crítica diante das cartografias. Para o geógrafo, “Os mapas são textos culturais. Ao aceitar sua textualidade podemos abarcar diversas possibilidades

56 "Criticism consists in uncovering that thought and trying to change it: showing that things are not as obvious as people believe, making it so that what is taken for granted is no longer taken for granted. To do criticism is to make harder those acts which are now too easy." (FOUCAULT, 2000:456)

57 Artigo publicado pela primeira vez na Revista Cartographica 26, n.2 (1989) p.1-20. 
interpretativas. Em lugar de ver somente a transparência da claridade, pode-se descobrir também a plenitude da opacidade" (2001, p. 159, tradução nossa).

Nesse sentido, para ele o ato interpretativo de ler um mapa pode cumprir funções importantes em uma ampla investigação na história da cartografia, como ampliar a compreensão do poder da representação cartográfica e de como se constrói ordem no mundo. Para o teórico, uma postura importante ao enfrentar a cartografia com olhos críticos é desconstruí-la, entendê-la, além de apenas tomá-la como um documento de localização.

"A desconstrução nos incita a ler entre as linhas do mapa, nas margens do texto, e através de seus trópicos, para descobrir os silêncios e as contradições que desafiam a aparente honestidade da imagem. Começamos a saber que os feitos cartográficos são somente realizados dentro de certa perspectiva cultural. Começamos a compreender que os mapas, assim como a arte, longe de serem uma ‘janela aberta ao mundo’ não são mais que "uma forma particular [...] de ver o mundo"58 (HARLEY, 2001, p. 153, tradução nossa)

Em seu artigo Text and Contexts in the Interpretation of Early Maps, Harley ressalta que assim como um texto, para se ler um mapa é preciso entender e se ater ao seu contexto. Mas não apenas como um simples pano de fundo, porém entender o seu contexto como uma interação de conjunto de forças:

"Para atingir isso, é necessário distinguir entre três aspectos do contexto que intercepta a leitura de mapas como texto. Os três aspectos do contexto em meu argumento são (1) o contexto do cartógrafo, (2) os contextos de

58 "Deconstruction urges us to read between the lines of the map - in the margins of the text"- and though its tropes to discovers the silences and contradictions that challenge the apparent honesty of the image. We Begin to learn that cartographic facts are only facts within a specific cultural perspective. We start to understand how maps, like art, far from being "a transparent opening to the world," are but "a particular human way ... of looking at the world."'(HARLEY, 2001, p.153) 
outros mapas e (3) o contexto social.” (2001, p. 38, tradução nossa) $)^{59}$.

Para Harley, o entendimento de quem é o cartógrafo e seu contexto é um importante e significativo ponto de partida para ler qualquer mapa. Porém, determinar a intenção do cartógrafo não é uma tarefa simples de se estabelecer, pois "todo mapa codifica mais de uma perspectiva do mundo" (HARLEY, 2001, p. 39, tradução nossa). Afinal, o autor bem relembra que os cartógrafos raramente trabalham de maneira independente, em sua maioria são financiados por alguém ou por algum órgão governamental, militar ou financeiro.

Todas essas forças contrastantes agem de forma sensível no tipo de cartografia e informação que será desenvolvido pelo cartógrafo. A representação das informações estará sempre suscetível a possíveis omissões, posturas tendenciosas e até mesmo deturpações. E esta possibilidade, o autor enfatiza, vale igualmente para mapas feitos com imagens aéreas produzidas por satélites, como já apontado no item anterior deste capítulo.

Ao tratar do segundo item, contextos de outros mapas, Harley enfatiza que nenhum mapa é fechado em si mesmo, ou seja, não consegue responder de forma autônoma às inúmeras questões que levanta. Para buscar resposta para certas perguntas, é preciso um exercício de comparação entre o mapa lido e outros do mesmo cartógrafo, outros da mesma época de produção, da mesma técnica e até mesmo com a ampla reprodução realizada em toda história da cartografia. O estudo comparativo pode ser revelador e clarear muitas outras questões. Importante para perceber como certos 'padrões' se modificam de uma cartografia para outra e que é preciso estar atento, pois até mesmo certas reproduções de mapas não costumam ser fidedignas ao modelo original.

E o terceiro elemento a se considerar, para ler e contextualizar um mapa, é o contexto social, pois, além do mapa manifestar regras elaboradas pelo próprio contexto do cartógrafo, o contexto social do momento também dita a hierarquia de informações e como são realizadas algumas representações. Harley assinala que essa etapa de leitura é de extrema importância: “Ao invés de pegar mensagens sociais que o mapa enfatiza, precisamos procurar o que

59 "to achieve this it is necessary to distinguish between three aspects of context that intersect the reading of map as text. The three aspects of context in my argument will be (1) the context of the cartographer, (2) the context of other maps, and (3) the context of society."(HARLEY, 2001, p. 38) 
desenfatiza; não tanto o que o mapa revela, mas o que omite. Interpretação se torna a busca do silêncio.’'(2001, p. 45, tradução nossa) ${ }^{60}$.

Posteriormente a Harley, surge uma série de outros estudiosos de destaque que passam a explorar a disciplina com lentes críticas e desenvolvê-las em seus estudos, como Denis Wood, John Pickles, Jeremy Crampton e John Krygier. A partir dessa leitura iniciada por Harley e os demais estudos que a seguem, surge um campo que passa a ser identificado por Crampton e Krygier (2005) como "Cartografia Crítica”, em um momento que possui um viés predominantemente político na análise das práxis cartográficas. Para Crampton (2010), a Cartografia Crítica não é uma cartografia puramente de rejeição, mas sim uma consideração cuidadosa da verdade que o mapa clama. No entanto, para Crampton a leitura de Harley de desconstrução dos mapas não é ampla o suficiente, pois para aquele autor o problema não estaria no mapa em si, mas nas pessoas que o fazem, e é desta postura de isentar o mapa que Crampton discorda. Para ele, o mapa não deve ser encarado como um objeto à distância, mas sim como parte do mundo, como algo aberto pronto a desvelar algo.

Em um artigo ${ }^{61}$ escrito pelos geógrafos Rob Kitchin, Chris Perkins e Martin Dodge, são identificados os principais teóricos que desenvolvem estudos a partir de Harley. E esse momento de intensos estudos e debates os autores identificam como 'Cartografia PósRepresentacional' o qual dividem em duas partes. A primeira passa do conhecimento ôntico ao ontológico, e a segunda, do ontológico à ontogenêsis.

O primeiro momento da Cartografia Pós-representacional (do ôntico ao ontológico) é marcado pelo movimento da teoria dos mapas em direção ao que está por trás do que todos veem - uma busca por reflexões e discussões que vão além do entendimento imediato e consensual que acontecia até então. São identificadas pelos autores (Kitchin, Perkins e Dodge) três principais frentes de aproximações ao entendimento de mapas: mapas como

60 "Instead of picking up social messages that the map emphasizes, we must search for what it de-emphasizes; not so much what the map shows, as what omits. Interpretation becomes a search of silences" (HARLEY, 2001, p. 45)

61 DODGE,Martin; KITCHIN, Rob; PERKINS, Chris. Thinking about maps. In: DODGE,Martin; KITCHIN, Rob; PERKINS, Chris (Ed). Rethinking Maps. New York: Routledge Studies in Human Geography, 2009. 
inscrições, mapas como proposições e mapas como dispositivos imutáveis e ativos.

Na primeira, 'Mapas como inscrições', destaca-se o teórico John Pickles; a ele interessa “[...] o trabalho que os mapas fazem, como agem para formar o nosso entendimento do mundo e como o codificam" (2004, p. 12, tradução nossa) ${ }^{62}$. Para esse estudioso, a cartografia não se limita a uma representação, mas atua como uma inscrição. Entende que a cartografia não apenas descreve ou explica o mundo, mas interage entre nós e o mundo - descreve o mundo conforme nosso método de questionamentos. "Não é uma representação do mundo, mas uma inscrição que funciona (ou `as vezes não) no mundo.“63 (PICKLES, 2004, p. 67, tradução nossa). O poder dos mapas é difuso, depende dos atores inseridos no contexto para potencializar seus efeitos.

Pickles conduz a reflexão acerca da cartografia para uma direção inédita. Antes se analisava a cartografia focando-se em como os desenvolvimentos histórico e social influenciaram o uso dos mapas. A partir de Pickles, é mostrada uma nova perspectiva: como a articulação cartográfica afeta o desenvolvimento social. Essa perspectiva apontada pelo autor inclui reflexões importantes, inclusive sobre o GIS. Pickles trouxe um olhar crítico já para os novos mapas mediados por tecnologias locativas, assumindo ser importante desconstruir e reconfigurar a cartografia científica para abrir possibilidades de examinar alternativas e novas formas de mapear.

Na segunda aproximação - 'Mapas como proposições' - destacam-se os teóricos Denis Wood e John Fels; em especial a partir de um artigo que publicaram conjuntamente, denominado The Nature of Maps: Cartographic Constructions of the Natural World (2008). Nele, os autores entendem que o mapa não simplesmente representa o mundo, mas o produz. Para eles, o mapa faz proposições, por exemplo, ao afirmar que uma coisa 'está aqui' e ao relacionar esta informação com outros dados espacializados no mesmo.

\footnotetext{
62 “ $[\ldots]$ Works that maps do, how they act to shape our understanding of the world, and how they code that world.”(PICKLES;2004:12)

63 "It is not a representation of the world, but an inscription that does (or sometimes does not to do) Work in the world.”(PICKLES;2004:67)
} 
No mesmo artigo, para ilustrar o ponto em que querem chegar, exemplificam com um caso a partir da planta de Ginseng. O mapa afirma que a planta de Ginseng (assunto proposto) é encontrada também dentro do Great Smoky Mountains National Park (predicado da proposição). Fazendo isso, conecta-se a planta a um sistema de normas e regulamentos, que é simplesmente uma outra maneira de se dizer 'National Park'. A partir dessa informação, já se sabe quais ações são permitidas, esperadas e possíveis com a planta Ginseng que se encontra na natureza (submetida a regras de um parque nacional). Somente por articular essas duas informações, o nome/tipo de planta ao local, já se torna possível extrair uma série de informações/normas e regras implícitas. Em outra publicação, Ce n'est pas le monde, Wood e Krygier reforçam esse conceito de mapas como proposições:

"Mapas são proposições. Mapas são proposições em forma gráfica. Tecnicamente, uma proposição é uma declaração em que o assunto/sujeito é afirmado ou negado por seu predicado, mas isto é precisamente o que o mapa faz, afirma a existência e localização de seu assunto/sujeito. Isto está lá, o mapa afirma novamente e novamente e novamente." ${ }_{64}$ (KRYGIER; WOOD, 2009, p. 198, tradução nossa)

Nessa mesma publicação, os autores se utilizam de ilustrações para exemplificar como mapas podem realizar proposições apresentando dados muito distintos. Nos primeiros dois quadros da figura 17, os autores mostram duas diferentes demarcações da Caxemira. Apesar de representar a mesma região, devido à diferente demarcação de fronteiras e nomenclaturas representam entendimentos políticos e históricos do local completamente diferentes. Segundo os autores, proposições de áreas de disputas como essas são de "fácil aceitação como mapas proposicionais porque 'todos' reconhecem limites e territórios como construções humanas"65 $(2009$, p. 214, tradução nossa).

Ainda na figura 17, o terceiro e o quarto quadros representam a área Artic National Wildlife

64 "Maps are propositions. Maps are propositions in graphic form. Technically a proposition is a statement in which the subject is affirmed or denied by its predicate, but this is precisely what a map does, affirms the existence and location of its subjects. This is there, the map affirms, again and again and again." (KRYGIER; WOOD, 2009, p. 198)

65 "very easy to accept as propositional maps because 'everyone' acknoledges that boundaries and territory are human constructs" (KRYGIER, WOOD; 2009:2014) 

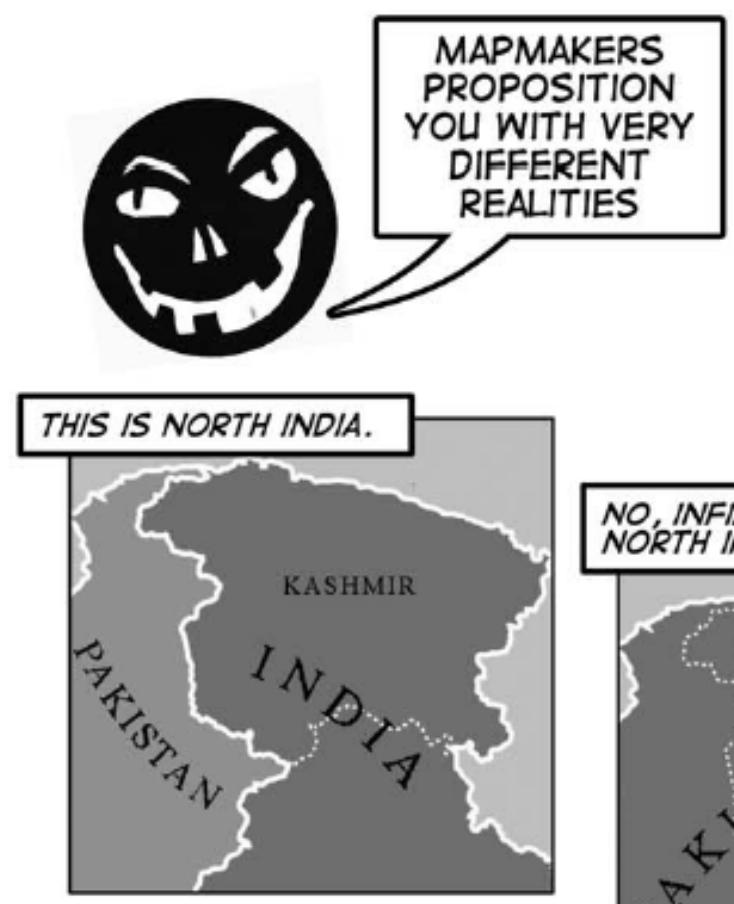

\section{THIS IS WHERE \\ CARIBOU CALVE IN} ANWR.

Caribou Calving Areas Arctic National Wildlife Refuge (ANWR)

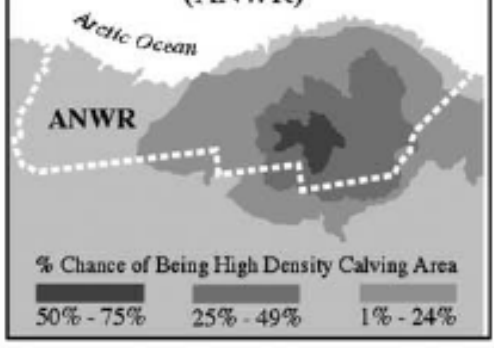
CARIBOL DON'T CALVE IN ANWR.

NO, INFIDEL, THIS IS NORTH INDIA.
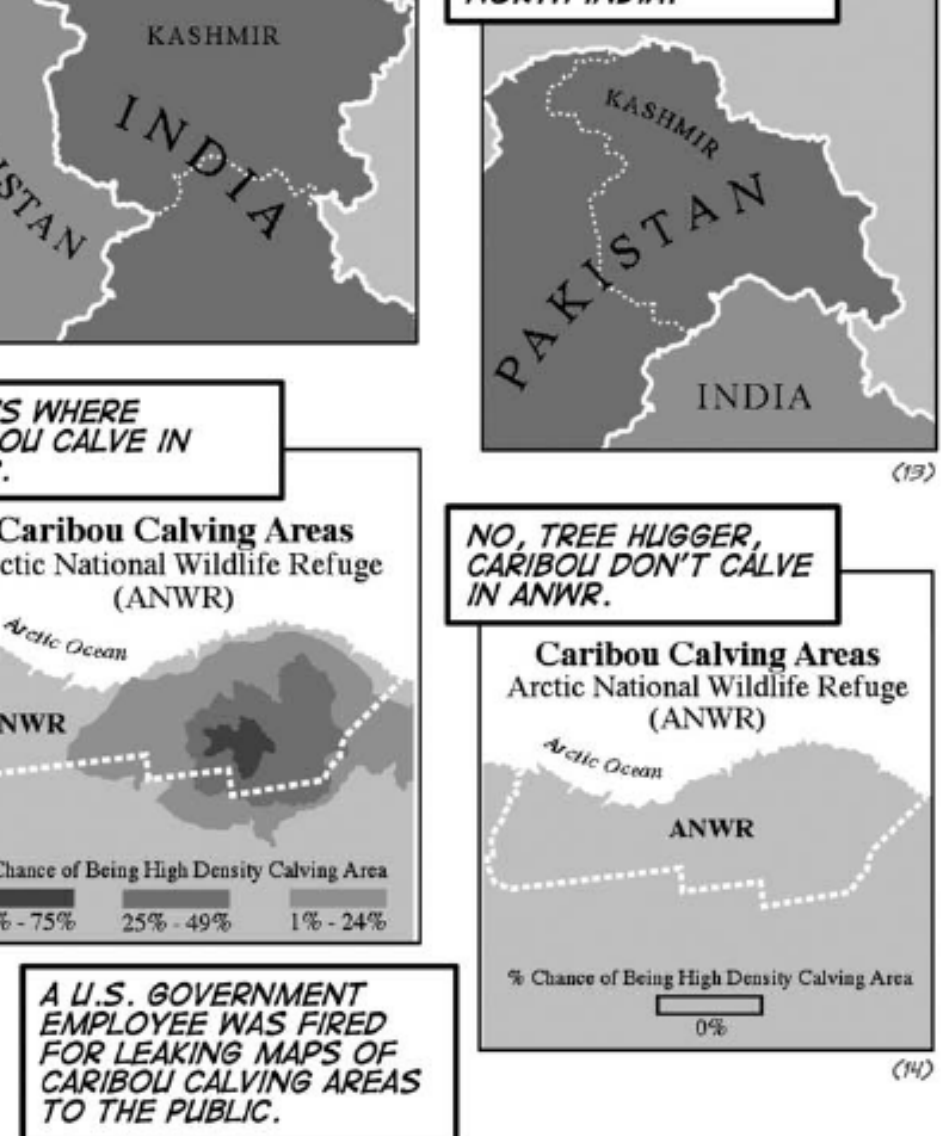

Caribou Calving Areas Arctic National Wildlife Refuge (ANWR)

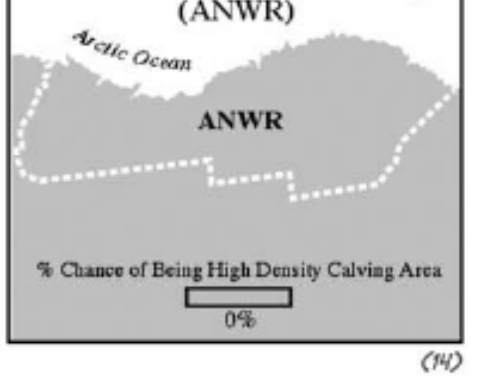

Figura 17 - Ilustração feitas pelos geógrafos KRYGIER e WOOD.

Fonte: artigo Ce n'est pas le monde (KRYGIER ;WOOD, 2009, p.202) 
Refuge: o terceiro quadro (esquerda) mostra com a escala de cores a densidade de recorrências de nascimento de filhotes de renas, enquanto no quarto quadro (da direita) essa informação é reduzida completamente a $0 \%$. Segundo os autores, o terceiro quadro (o que possui a escala de cores) não deveria ter sido publicado, uma vez que, segundo o governo americano, pouco se sabe sobre o assunto - e ao que parece esse mapa foi publicado por um funcionário sem maiores estudos. Para o governo americano, o mapa correto a ser publicado é o do quarto quadro (com $0 \%$ ). Independentemente de as alegações serem, fica claro que a interpretação possível de cada uma delas é completamente distinta e evidente: como a presença de legendas pode alterar completamente o peso e profundidade de leituras do mapa.

Wood, desde a publicação de seu livro The Power of Maps (1992), ressalta que sempre há nos mapas algum interesse/informação implícito, apontando que os mapas utilizados para servir o Estado também poderiam servir ao povo com o mesmo potencial. Denis Wood é um dos estudiosos que começam a olhar para o uso de mapas como resistência, uma forma de se propor mudanças, aspecto esse importante que será aprofundado mais adiante.

Em relação aos "mapas como dispositivos imutáveis e ativos", Kitchin, Perkins e Dodge destacam Bruno Latour que, em seu livro Science in Action (1987), discute como a produção da ciência ocidental apresenta a cartografia como uma linguagem autoritária, que com apoio tecnológico e desenvolvimento de precisão ganha um caráter de padronização de informações. A prática cartográfica ocidental passa a ser um artefato que permite apropriar-se de ações à distância e garante, segundo o autor, a hegemonia ocidental pelo mundo. Conforme os mapas se tornam cada vez mais convencionais, eles adquirem o caráter de imutabilidade, segundo Latour. Tornam-se uma linguagem familiar, pois passam a seguir protocolos e normas e se tornam conhecimentos combináveis e transferíveis que podem ser levados pelo tempo e espaço. E, por isso, encarados como dispositivos móveis e imutáveis.

\footnotetext{
"A imutabilidade dos mapas é, então, em um nível, uma ilusão poderosa, mas uma que prontamente funciona no mundo. Latour afirma que a imutabilidade, combinabilidade e mobilidade dos mapas permitiram o
} 
desenvolvimento da exploração, do comércio e finalmente do colonialismo ao permitir o controle ser exercido a distância e conhecimentos sobre novos territórios serem efetivamente transportados globalmente." ${ }_{66}$ (KITCHIN; PERKINS; DODGE, 2009, p. 15, tradução nossa)

No entanto, Latour sugere que não basta conhecer a cultura, a tecnologia e a mecânica de como um mapa ganha imutabilidade e mobilidade, mas também é preciso considerar a teoria ator-rede ${ }^{67}$, atores que estão envolvidos no contexto. Deve-se considerar os mapas como construções sociais, ou seja, não possuem significado ou ações isoladas, mas fazem sim parte de um conjunto de pessoas, processos discursivos e coisas materiais. Por isso, algo atuante e não estático; trata-se de uma visão que difere bastante da visão cientificista em que mapas eram objetos isolados e estudados à distância.

“Os mapas não têm significado ou ação por conta própria; eles são parte de um conjunto composto por pessoas, processos discursivos e coisas materiais. Eles são implantados em uma prática de rede de atores ao invés de existir como objetos de conhecimento des-corporalizados, a priori, não-ideológicos. (KITCHIN; PERKINS; DODGE, 2009, p. 16, tradução nossa $)^{68}$

Em um artigo, escrito em conjunto com Valérie November e Eduardo Camacho-Hübner, Latour aponta, por exemplo, como a navegação digital transforma o uso e a produção dos mapas. Como características de antecipação, participação, reflexividade e comentários são

66 "The immutability of maps is then at one level a powerful illusion, but one that readily does work in the world. Latour contends that immutability, combinability and mobility of maps allowed exploration, trade and ultimately colonialism to develop by allowing control to be exerted from afar and knowledges about new territories to be effectively transported globally." (KITCHIN, PERKINS, DODGE; 2009:15)

67 Actor-Network Theory (ANT) - Teoria desenvolvida nos estudos da ciência tendo como um dos principais teóricos Bruno Latour. A teoria, de maneira simplificada, explica que, na cultura contemporânea, os atores não humanos (que podem ser um dispositivo inteligente, como computadores, smartphones, sensores, wearables, servidores, entre outros) e humanos agem mutuamente, interferem e influenciam o comportamento um do outro, com a diferença de que o não humano pode ser ajustado pelo humano de acordo com a sua necessidade.

68 "Maps do not have meaning or action on their own; they are part of assemblage of people, discursive processes and material things . They are deployed in an actor-network of practices rather than existing as de-corporalized, a priori, non-ideological knowledge objects." (KITCHIN; PERKINS; DODGE, 2009, p. 16) 
partes da definição de navegação dos mapas hoje. A ubiquidade que já existia nos mapas impressos aumenta exponencialmente com o uso do formato digital.

"a experiência que temos de engajamento com mapeamentos é a de logar em algum banco de dados que reúne informações em tempo real através de uma interface [...] Um bônus adicional é que a plataforma permite ao usuário adicionar novas informações pessoais no banco de dados, transformando assim o usuário do mapa em um da sua miríade de contribuintes amadores ${ }^{69}$ (NOVEMBER; HÜBNER; LATOUR, 2009, p. 583, tradução nossa).

É possível perceber que nessas três frentes (inscrição, proposição, dispositivos imutáveisativos) do desenvolvimento da primeira metade da Cartografia Pós-Representacional, do ôntico ao ontológico, o foco de atenção dos teóricos fica marcado por como os mapas são produzidos e como atuam no mundo.

Já a segunda parte, do ontológico à ontogênese, o desenvolvimento dos estudos passa a buscar entender como acontecem os processos de transformação dos mapas, partindo da sua representação até a sua prática. Nesse momento, os estudos identificam a cartografia com uma perspectiva relacional, como os autores mesmos afirmam: “[...] Houve uma movimentação para considerar a cartografia a partir de uma perspectiva relacional, tratando mapas não como representações uniformes mas como constelações de processos em andamento." ${ }^{70}$ (KITCHIN; PERKINS; DODGE, 2009, p. 16, tradução nossa)

Os mapas passam a ser assumidos como práticas, como propõem os estudiosos Kitchin e Dodge $^{71}$ :

\footnotetext{
69 "experience we have of engaging with mapping is to log into some databank, which gathers information in real time through some interface. (...) An added bonus is that the platform allows the user to add fresh personal informatio to the bank, thus transforming the user of the map into one of its myriad amateur contributors. " (NOVEMBER; HÜBNER; LATOUR, 2009, p. 583).

70 " [...] There has been a move towards considering cartography from a relational perspective, treating maps not as unified representations but as constellations of ongoing processes." (KITCHIN; PERKINS; DODGE, 2009, p.16)

71 Artigo 'Rethinking Maps' 2007 - Rob Kitchin e Martin Dodge.
} 
“[...] transitórios e fugazes, sendo contigentes, relacionais e dependentes do contexto. Mapas são práticas - são sempre mapeamentos; práticas espaciais promulgadas para resolver problemas relacionais [...]" (KITCHIN; DODGE, 2007, p. 335, tradução nossa $)^{72}$

Percebe-se, portanto, uma atenção dos teóricos para além de mapas convencionais, sendo que as práticas espaciais de interação com o mundo passam a fazer parte do foco de estudos. A cartografia pós-representacional apresentada pelos três autores (Figura 18) segue em sentido contrário à condição dos 'mapas como a representação da verdade', apontando-os como construções sociais. Mapas/projeções eram constantemente revisados e recalculados, como foram os casos, por exemplo, das projeções de Ptolomeu, Mercartor, van Griten, Arno Peters e assim por diante. Antes, a preocupação era tornar esses mapas cada vez mais objetivos e científicos. A neutralidade e objetividade que antes eram atribuídas aos mapas são, portanto, colocadas em xeque, e as várias camadas de poder (social, político, econômico, cultural) passam a ser desveladas.

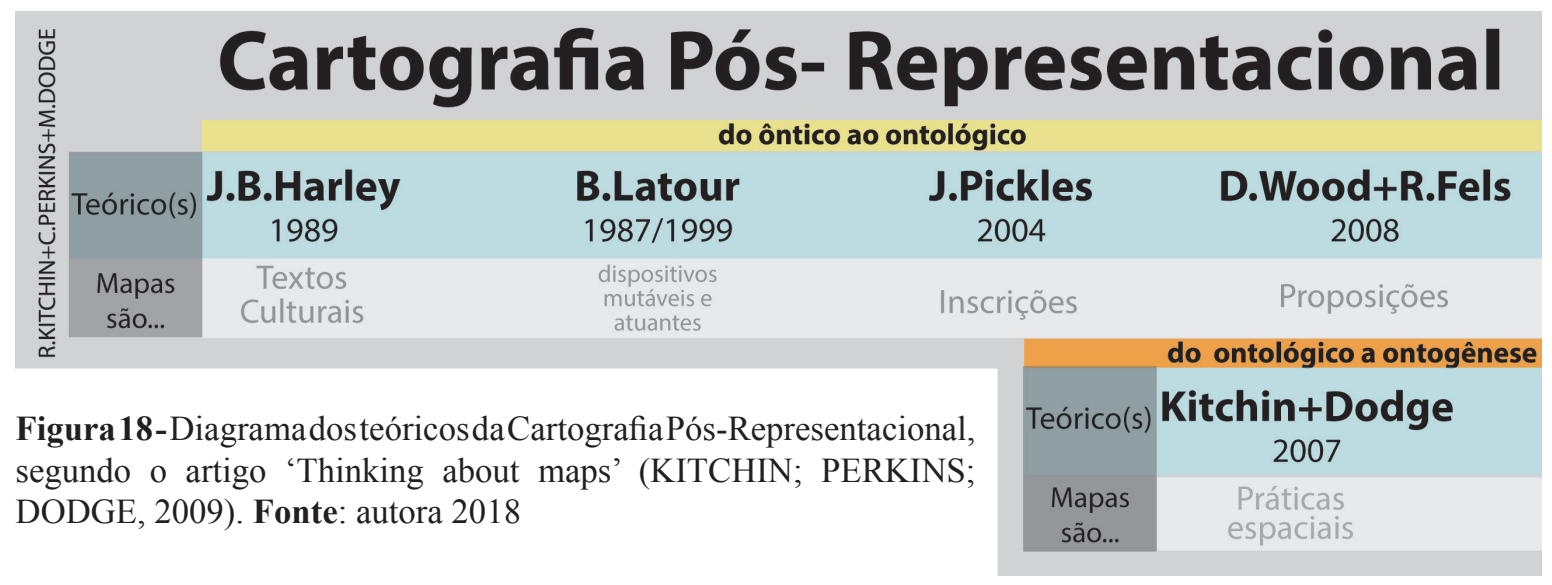

Tendo percorrido essas variadas vertentes de estudos e reflexões críticas sobre a cartografia, percebe-se que os diversos autores apontam aspectos que porvezes sobrepõem-se parcialmente ou tangenciam entre si; no entanto, fazem um uso diversificado de termos que são chaves para o desenvolvimento deste trabalho.

72 “ $[\ldots]$ maps are transitory and fleeting, being contigent, relational and context-dependent. Maps are practices - they are Always mappings; spatial practices enacted to solve relational problems [...]” (KITCHIN; DODGE, 2007, p. 335) 
Crampton e Krygier (2005), como já mencionado, utilizam o termo 'Cartografia Crítica' como uma cartografia que "desafia a cartografia acadêmica ao associar o conhecimento geográfico com poder e, portanto, é política" (2005, p. 1, tradução nossa) ${ }^{73}$. Para os autores, o entendimento de crítica está alinhado com Foucault, para quem, como mencionado, ela vai muito além de encontrar falhas e defeitos em algo, mas é ativada em uma análise dedicada às premissas que compõem esse algo.

Denis Wood, por sua vez, ao refletir sobre a cartografia, demonstra o poder dos mapas em expressar e defender interesses particulares de maneiras implícitas, e de como o Estado faz uso dessa linguagem para interesses próprios. Para tanto, o autor sugere uma cartografia de manifesto, introduzindo o termo ‘contra-mapeamento' nos estudos cartográficos. O termo já havia sido cunhado em 1995 em um artigo ${ }^{74}$ escrito pela antropóloga Nancy Peluso, no qual a estudiosa atribuiu o termo aos mapas concebidos pelos aborígenes que estudava. Para ela, eram mapas que manifestavam conhecimento, necessidades, identidades e prioridades do povo local, diferentemente dos mapas ocidentais que impunham e anulavam sua identidade.

Wood, no entanto, em seu livro Rethinking tha power of maps(2010), afirma que o contramapeamento possui como raíz uma fusão de várias fontes, como: "Mapas de práticas artísticas do início do século XX; nos movimentos de mapeamentos mentais de 1960; nos mapeamentos indígenas e biorregionais, cartografia crítica e mapeamentos locais" (2010, p. 111, tradução nossa). ${ }^{75}$ Essa diversidade de cruzamentos disciplinares é o que garante a percepção ampliada do mundo, especialmente de suas injustiças e, por isso, essa visão ampliada, acompanhada de inquietações sociais e políticas potencializa os mapas e mapeamentos para uma outra direção.

O autor ainda reforça que, mais do que focar demasiadamente nas novas tecnologias, são

73 "Critical cartography challenges academic cartography by linking geographica knowledge with power, and thus is political." (CRAMPTON; KRYGIER, 2006, p.11)

74 PELUSO, N.L (1995). "Whose Woods are These? Counter-Mapping Forest Territories in Kalimantan, Indonesia". Antipode. 4. 27: 383-406, 1995.

75 “(...) map art practices that date to the early 20th century; in the mental maps movement of the 1960s; in Indigenous and bioregional mapping and critical cartography and Parish Mapping (...)" (WOOD;2010:111) 
as "novas atitudes, visões e filosofias radicais de contramapeadores que realmente levam os mapas e o fazer dos mapas para uma nova direção, uma direção com potencial de libertar finalmente os mapas da tirania do Estado.” (2010, p. 111, tradução nossa) ${ }^{76}$. Para ele, mapear contra o poder do Estado é uma forma de resistência ao poder autoritário.

Essas reflexões de uso da cartografia como expressão de crítica se disseminam em novas propostas no campo das artes e do ativismo social-político. É justamente um artista ativista, e não um cartógrafo, que propõe o termo 'contracartografias'. Brian Holmes, no texto Counter Cartographies presente no livro Else/Where: mapping new cartographies of networks territories, indica um embate entre cartografias dominantes e hegemônicas com as contracartografias. Para o autor, grupos de artistas e ativistas se apropriam da linguagem da cartografia dominante de forma criativa e, através de construções colaborativas, geram uma rede de dados que, além de possibilitar novas leituras, produz novos discursos e propõe novas apropriações e outros redesenhos do espaço.

"Cartografias críticas e dissidentes surgem contra o fundo da tecnologia dos mapeamentos dominantes. Elas aparecem como contracondutas no sentido dado por Michel Foucault." (HOLMES, 2006, p. 25, tradução nossa) ${ }^{77}$

Para este trabalho, entende-se que os termos 'cartografia crítica', 'contramapeamentos', 'contra-mapas' e 'contracartografias' são similares, e que a variação ocorre mais por uma variação de disciplina de estudos que foca no assunto do que pelo uso por haver definições diferentes. No entanto, o foco será direcionado ao termo adotado por Holmes, uma vez que nos interessa entender como grupos de ativistas e artistas têm se utilizado das cartografias para trazer suas discussões, manifestos e enfrentamentos à tona. E quais as qualidades e particularidades do olhar artístico que o artista cartógrafo traz para essa dimensão da contracartografia.

\footnotetext{
76 “(...)It's the new attitudes, visions, and radical philosophies of the counter-mappers that are really taking maps and mapmaking in a whole new direction, a direction with potential to free maps at last from the tyranny of the state."(WOOD;2010:111)

77 Para Foucault 'contracondutas' refere-se a um sentido ativo “[...] de luta contra os procedimentos postos em prática para conduzir os outros.” FOUCAULT, M. Segurança, Território, População: Curso ministrado no Collège de France (1977-1978). São Paulo: Martins Fontes, 2008.
} 


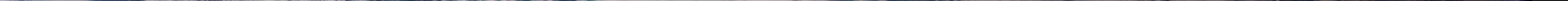




\section{Capítulo 2}

\section{Mundos [Contra]cartografados}


O uso e grafia do termo "espaços (contra) cartografados" no título do capítulo assume a existência de disputas no uso das cartografias para conferir visibilidade a dados e fatos. Faz uso dos parênteses para evocar dois sentidos, um que destaca a possibilidade do 'contra', ou seja, quando a cartografia é utilizada para enfrentar hierarquias de poder dominantes como abordado por Holmes e Wood no capítulo anterior; e outro, que recobra o próprio significado de cartografia, com suas limitações e falta de neutralidade também já descritas no capítulo anterior.

Após o desenvolvimento de tópicos teóricos e históricos dentro de uma abordagem representacional, seguido das mudanças ontológicos e epistemológicos da concepção pós-representacional de mapeamento, este capítulo se propõe a abordar e aprofundar desdobramentos da cartografia e da contracartografia a partir do uso das mídias locativas. Em outras palavras, como as cartografias procedem agora em plataformas digitais, quando passam a mediar significativamente as formas de localização do homem contemporâneo. $\mathrm{E}$ ainda, como neste contexto, leituras e manifestações ativistas produzem contracartografias em meios digitais.

Como já discutido no primeiro capítulo, não há neutralidade nos mapas, mesmo nos baseados via imagens de satélite. Há, portanto, um importante binômio que volta a ser reforçado neste momento do segundo capítulo, que é o tema visibilidade e invisibilidade. Binômio esse que se apresenta de maneira muito mais complexa e velada com o uso de dados georreferenciados e redes de colaboração. As contracartografias trazem neste contexto, a tônica de dar visibilidade ao que inicialmente é silenciado, denunciando ocorrências ou expondo recursos/informações não conhecidos, com os mesmos recursos de mídias locativas e dados geolocativos.

\section{1- A PERVASIVIDADE DOS MAPAS COLABORATIVOS}

No início de 2004, O’ Reilly (profissional e estudioso na área de mídia Web e informática) cunha o termo Web 2.0. O termo designa a nova fase que a World Wide Web adquire, deixando de ser apenas uma sequência de hyperlinks e de ter o caráter apenas de consulta 
(Top-Bottom). É nesse momento que serviços de redes e websites são utilizados como plataforma de geração de conteúdo; surgem blogs, podcasts, wikis, entre outros. Qualquer um poderia se tornar um criador de conteúdo e disponibilizá-lo na rede.

O geógrafo Georg Gartner, em seu artigo, 'Web mapping 2.0'78, ressalta que essa passagem para a Web 2.0 não acontece apenas por alguma mudança tecnológica, mas por uma transformação epistemológica.

“[...] não há uma única e simples definição para Web 2.0 e nenhuma ecnologia dirigindo seu desenvolvimento. Mas sim uma abundância de novas ideias e aplicativos estão gerando uma mudança no significado e uso da web.”’9 (GARTNER, 2009, p. 68, tradução nossa)

Neste mesmo artigo, Gartner utiliza o termo Web mapping 2.0 para se referir a aplicativos (Web 2.0) que utilizam informações geolocativas somadas a um caráter colaborativo. Uma informação geolocativa, como já foi abordado no item 1.2 do capítulo anterior, é a que está associada a uma coordenada GPS. Os avanços tecnológicos, em especial com o surgimento do GIS, tornam essas associações informacionais possíveis e dão vazão a uma outra maneira de representar localizações como o Google Earth.

É a partir do desenvolvimento dos mapas digitais (Web mapping 2.0) que surgem os mapas colaborativos. É neles, por exemplo, que há uma movimentação de informações entre Big Data $^{80}$ e o Small Data ${ }^{81}$ em tempo real; em outras palavras, usuários/colaboradores dos mapas

78 (GARTNER, 2009)

79 “ $(\ldots)$ there is no single, simple definition for Web 2.0 and there is no single, new technology that is driving its development. Rather a plethora of new ideas and applications are generating a shift in the meaning and use of the web." (GARTNER; 2009:68)

80 Big Data: termo relativamente novo, o ato de recolher e armazenar grandes quantidades de informações para eventual análise de dados é bem antigo. O conceito ganhou força nos anos 2000, quando um analista do setor, Doug Laney, articulou a definição de big data como os três Vs: Volume, Velocidade e Variedade.

Volume - Organizações coletam dados de fontes variadas (transações comerciais, redes sociais, sensores...) armazenando um volume grande de informações. Velocidade- Dados são transmitidos e tratados em tempo real. Variedade - Dados são gerados dos mais diferentes formatos (dados numéricos, texto, vídeo, áudio, cotações, transações...)

81 Small Data: são dados em um volume e formato que os tornam acessíveis, informativos e acionáveis. Small data normalmente fornecem informações que respondem a uma pergunta específica ou abordam um problema específico. 
podem fazer upload de informações com a mesma facilidade que o download delas. Diversos usuários das mais variadas esferas sociais e políticas, movidos por algum interesse comum de consumo (e produção) de informação, participam ativamente de um mapa, alimentam com informações e impressões pessoais bem como interagem com as mais diversas informações postadas pelos demais.

Em se tratando da qualidade e procedência de dados, vale também trazer aqui uma relação interessante levantada por Gartner. Quando trata dos mapas colaborativos, o autor traz o termo 'mashup' (do inglês, mistura), que define como "um aplicativo web que combina dados de mais de uma fonte em uma única ferramenta integrada, mas é muito mais do que uma simples incorporação de dados de outro site para formar um documento composto." "82 (2009, p. 71, tradução nossa). A ideia não é nos aprofundarmos em aspectos técnicos de programação e informática, mas uma faceta presente e importante assinalada por Gartner, geógrafo que se ocupou em entender os mapas digitais colaborativos; é que, quando um mapa desses lida com diversos tipos de informações, também lida com diferentes fontes informacionais.

Como ele desenvolve em seu artigo, para criar um mapa colaborativo uma das maneiras mais utilizadas é compondo um mashup. Para isso, utiliza-se um aplicativo - base para fornecer o mapa e os dados georreferenciais, para serem cruzados com os outros dados que virão de outros aplicativos que serão incorporados ao mashup. E Gartner identificou que o aplicativo de mapas mais utilizado como base para vários mashups é o Google Maps API - algo que também não passou desapercebido ao longo desta pesquisa, especialmente após observar e atentar nos aplicativos geolocativos e inclusive mapas colaborativos de ativistas (que serão apresentados mais adiante, ainda neste capítulo). E essa concentração, já notada a partir dos dados de 2008, continua, segundo Gartner:

"Eles (Google) incentivam mashups para poder usar dados voluntariados para seus próprios interesses comerciais. Assim, pode-se argumentar

\footnotetext{
82 "A mashup is a web application that combines data from more than one source into a single integrated tool, but is much more than a simple integrated tool, but is much more than a simple embedding of data from another site to form a compound document." (GARTNER, 2009, p.71)
} 
que o aplicativo Web 2.0 meramente replica divisões digitais, ao invés de subverter ou oferecer mudanças radicais."83 (GARTNER, 2009, p. 76, tradução nossa)

Assim, além dessas bases informacionais que são adotadas para construir os mapas colaborativos, também se conta com a atividade de input de dados por parte dos usuários. Linda See, Steffen Fritz e Jan de Leeuw afirmam que este é um momento em que "um cidadão ordinário se transforma em neogeógrafo ${ }^{84}{ }^{85}$ (2013, p. 955). O usuário, tendo acesso à mídia locativa, pode criar, personalizar e mapear informações de seu interesse. Há uma certa democratização do papel do cartógrafo; as informações geolocativas provenientes de usuários (não necessariamente experts), alimentam uma rede com informações georreferenciadas em tempo real, produzindo VGIs - do termo em inglês 'volunteered geographic information'. Ao mesmo tempo em que há essa abertura para input de dados por parte dos usuários, o acesso à totalidade dos dados ainda é concentrado; cabe apenas às grandes empresas que possibilitam essas plataformas, Google por exemplo.

Ainda segundo os autores, os mapeamentos colaborativos "podem oferecer uma solução para obter mais dados espaciais atualizados, ou, em algumas situações, podem formar a única fonte de informação disponível.” (2013, p. 956). Eles ressaltam que o grande desafio dos mapas colaborativos é contar com a qualidade e precisão dos dados que são inseridos pelos usuários; apesar de ser uma forma de mapeamento cada vez mais frequente, saber trabalhar e qualificar esses geodados é importante.

Entender como dados que se acumulam e se consomem é imprescindível para entender a qualidade do mapa. No entanto, além da qualidade dos dados, a quantidade é igualmente relevante, pois, quanto maior o número de usuários ativos em uma rede colaborativa, maior a chance de precisão das informações. Os autores Laura Criscuolo, Monica Pepe, Roberto

\footnotetext{
83 " They encourage mashups so as to be able to use voluntenteered data for their own comercial gendas. So it could be argued that Web 2.0 application merely replicate digital divides, instead of subverting or offering radical change.” (GARTNER, 2009, p. 76)

84 O termo 'neogeografo' faz referencia ao termo 'neogeografia' cunhado na área de geografia para referenciar mapas digitais criados por leigos (não geógrafos/não especialistas).
} 
Seppi, Gloria Bordogna, Paola Carrara e Francesco Zucca tratam, em seu artigo, justamente sobre a qualificação e classificação de dados. Para eles, dados provenientes de usuários físicos comuns que alimentam aplicativos/mapas/sites colaborativos são chamados de "informações incidentais" "86. Trata-se de dados que são compartilhados de forma indireta pelos usuários, ou seja, com a postagem de uma foto, por exemplo. Além da informação da imagem, acompanham com ela as coordenadas do local da foto, especificações do equipamento, data, horário, notas do autor da foto, entre outros.

“Todos esses tipos de informações incidentais geralmente são distribuídos através da web por meio de fóruns, blogs, páginas web, álbuns de fotos na web, aplicativos sociais e geográficos (por exemplo, aplicativos para mapeamento social ou globos virtuais). Eles são geralmente acessíveis ao público em geral de forma gratuita, e frequentemente são fornecidos com ferramentas sociais para compartilhar, comentar e avaliar conteúdos. Os dados incidentais geralmente são acompanhados de metadados escassos ou ambíguos" $"$. (CRISCUOLO, et al. 2013, p. 687, tradução nossa)

Os mapas colaborativos têm propiciado o uso da localização como modo de compartilhar interpretações do espaço. Essas interpretações podem ser as mais variadas, desde algo mais subjetivo como uma impressão ou memória pessoal até informações políticas e econômicas. Os pesquisadores em Comunicação e Cultura Contemporâneas José Carlos Ribeiro e Leonardo Branco Lima, em artigo sobre Mapas Colaborativos, levantaram aspectos de ordem econômica, política e cultural desses mapas. Para os autores “[...] a dimensão econômica é centrada em seu valor de uso, isto é, na possibilidade de micro-apropriações, nas quais a utilização do mapa como mediação entre os indivíduos e o território é a questão substancial" (2011, p. 43).

86 Incidental data.

87 "All these types of incidental information are usually distributed via the web by means of forums, blogs, web pages, web photo albums, an social and geographic applications (for instance, applications for social mapping or virtual globes). They are commonly accessible to the general public for free, and are frequently provided with social tool for sharing, commenting and rating contents. Incidental data are often accompanied by scarce or ambiguous metadata." (CRISCUOLO, et. al. 2013:687) 
A mediação através dos mapas colaborativos, em especial com as mídias locativas, feita entre o território e o usuário, se torna indispensável para o reconhecimento e valoração do espaço. A dimensão política, ainda segundo os autores, diferentemente dos mapas impressos do século passado, gera um interesse na escala do território efetivamente vivenciado, ou seja, para o usuário/colaborador interessa o seu trajeto, seu roteiro e seus lugares de convívio. Nesse sentido, a ordem cultural também acontece na escala do espaço vivido, demarcando uma relação de pertencimento com o território.

"Os mapas, enquanto instrumentos que exercem a função de mediadores de informações associadas a determinado espaços e localizações geográficas, se configuram, desta forma, em elementos intervenientes importantes na construção de representações sociais, uma vez que revelam aspectos e características particulares de um determinado contexto, assim como ajudam na organização das experiências no curso da vida diária" (RIBEIRO; LIMA, 2011, p. 45)

Diante desse contexto, dessa mediação intensa por aparelhos locativos e trocas de dados surgem os termos como crowdsourcing e crowdsensing, que esclarecem algumas dinâmicas importantes que ocorrem no input de dados por parte dos usuários nos aplicativos e mapas colaborativos. O crowdsourcing é um método de coleta de dados pelo qual os usuários contribuem livremente para a construção de um banco de dados espacial. Um exemplo de uma plataforma tipicamente de crowdsource é o Wikipidia.

Já o crowdsensing trata-se de informações processadas por aparelhos locativos, isto é, quando o sistema se apropria de informações disponibilizadas pelo usuário que geram novas articulações informacionais. Ganti, Ye e Lei, autores do artigo 'Mobile Crowdsensing: Current State and Future Challenges ${ }^{\prime 8}{ }^{8}$ sobre crowdsensing, classificam que o crowdsensing pode ser dividido em duas categorias:

Uma é o personal sensing application, em que os dados pessoais de um individuo são processados/articulados com outros, gerando mais dados para o próprio indivíduo. Podemos 88 (GANTI; YE; LEI, 2011) 
citar aqui, como exemplos, aplicativos de saúde, que marcam a passada de corrida/caminhada do sujeito juntamente com o batimento cardíaco, gerando ao final um mapa completo do que foi percorrido somado a mais uma série de informações referentes à saúde fisiológica do usuário como: perdas calóricas, tempo médio, pico de esforço, hidratação, dentre outros.

A outra categoria, a que mais nos interessa, é a que os autores chamam de community sensing, que se refere ao monitoramento de fenômenos/informações de grande escala que não podem ser facilmente medidos por um único indivíduo. São processadas informações de uma rede de colaboradores para gerar outros dados. Isso pode se dar de duas maneiras: de maneira consciente e voluntária que é denominada participatory crowdsensing, ou de maneira velada, em que normalmente os usuários não têm ciência de como seus dados estão sendo utilizados e articulados, que é denominada opportunistic crowdsensing.

O modo opportunistic crowdsensing é uma modalidade mais autônoma, na qual informações pessoais são coletadas e automaticamente compartilhadas sem um consentimento claro do usuário. Normalmente; são as letras miúdas dos downloads gratuitos de aplicativos, ou os termos de uso que são aceitos para participar de alguma rede colaborativa.

Um exemplo prático de um mapa colaborativo, que possui caráter crowdsourcing de funcionamento e também uma articulação de dados crowdsensing, é o Waze ${ }^{89}$ (Figura 19). Um aplicativo de mídias locativas que, muito além de funcionar como um simples GPS, consegue informar intensidade do trânsito, presença de autoridades, acidentes, radares, buracos e defeitos na estrada entre outras informações relativas ao trânsito. O programa consegue manter todas essas informações atualizadas na plataforma de mapa digital devido à alimentação constante, em tempo real, por parte dos usuários. A qualidade e precisão das informações dependem, portanto, da quantidade de usuários que percorrem determinadas regiões do mapa, ou seja, em locais em que há uma baixa utilização, o aplicativo deixa de ter a eficiência prometida.

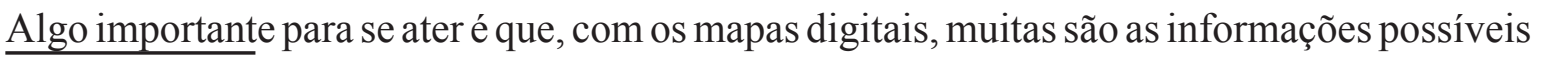
89 https://www.waze.com 

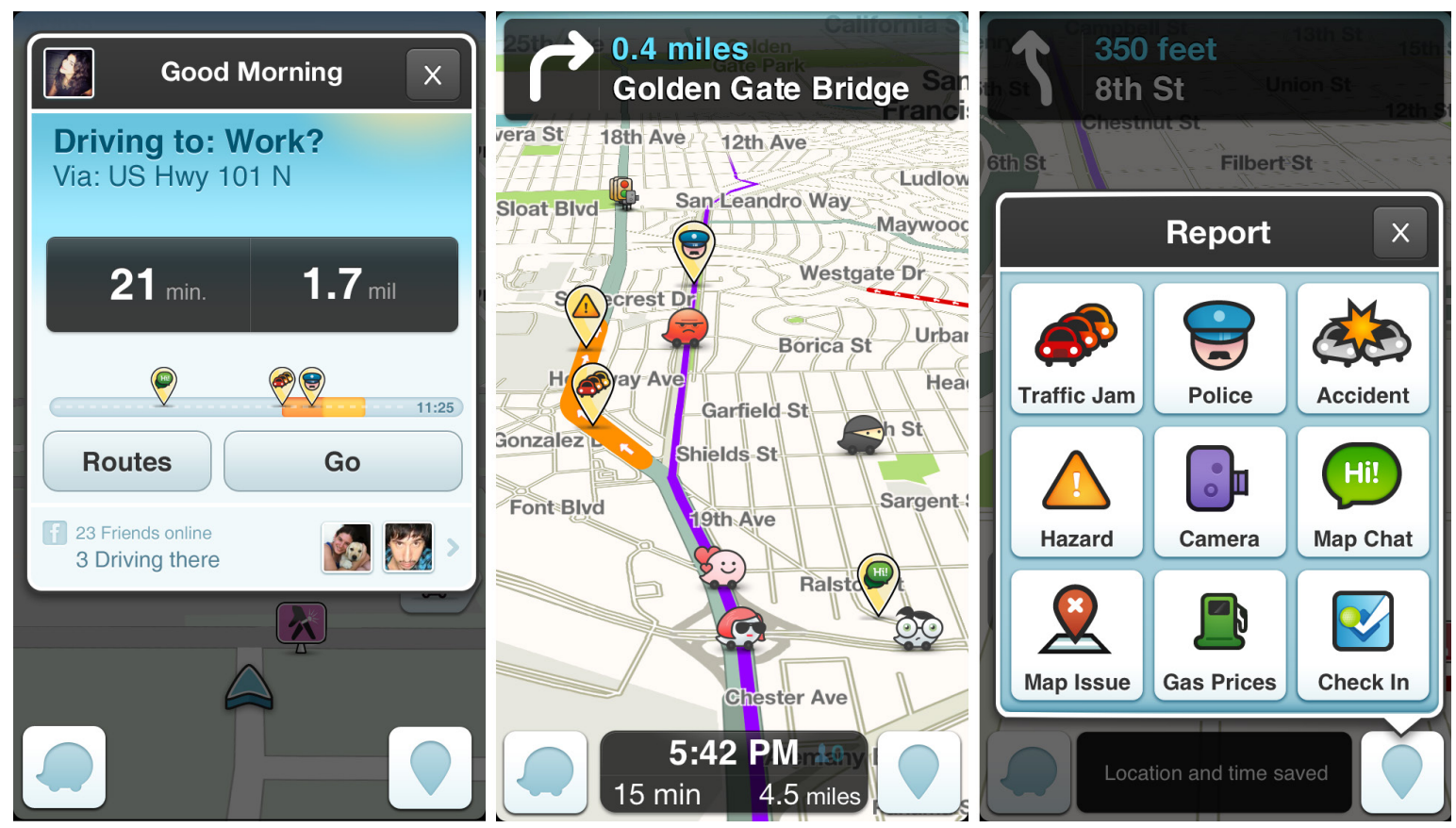

Figura 19- Interfaces do aplicativo Waze. Fonte: Waze app

de serem associadas, e isso gera uma necessidade de hierarquia de visibilidades dos dados. Como Alison Sant ressalta: “A hierarquia espacial do mapa é reforçada pela prática diária de navegar em uma nova cidade, encontrar uma parada de metrô ou um endereço comum. No entanto, incorporado nessas referências cotidianas há um conjunto de pressupostos que ordenam percepções do espaço físico"90 (SANT, 2006, p. 1, tradução nossa)

As sobreposições de informações possuem uma ordem predeterminada por quem oferece o mapa, ou seja, quem controla a base de dados. Pensar sobre a relação de visibilidade e invisibilidade de informações é importante para um entendimento crítico dos mapas e suas representações. Como bem coloca Laura Kurgan, a invisibilidade de dados traz consigo uma quietude que nos impõe a espacialidade que bem entender.

90 The spatial hierarchy of the map is reinforced by the daily practice of navigating a new city, finding a subway stop, or an unfamiliar address. However, embedded in these everyday references is a set of assumptions that order perceptions of physical space" (SANT;2006, p.1) 
"Parece que até mesmo no final, mapas - os bem-sucedidos, os que nos mostram onde estamos e nos levam daqui até lá - arriscam-se oferecendo duas alternativas. Eles nos deixam ver demais, e daqui nos cegam o que não podemos ver, impondo uma tirania quieta de orientação que apaga a possibilidade da descoberta desorientada, ou de perder de vista um tanto de outras coisas que poderíamos ver. Eles omitem, de acordo com suas convenções, aquelas linhas invisíveis de pessoas, lugares e redes que criam os espaços mais comuns que vivemos nos dias de hoje."91 (KURGAN, 2013, p. 16, tradução nossa)

Muito antes da profusão dos mapas digitais, o pensador Jean Baudrillard já afirmava que com a pós-modernidade, os significados seriam precedidos pelos significantes. Em outras palavras, uma ruptura entre a realidade e sua representação.

"Hoje a abstração já não é a do mapa, do duplo, do espelho ou do conceito. A simulação de um território, de um ser referencial, de uma substância. É a geração pelos modelos de um real sem origem nem realidade: hiper-real. O território já não precede o mapa, nem lhe sobrevive. É agora o mapa que precede o território.” (BAUDRILLARD, 1991, p. 8)

Baudrillard discorria sobre abstração e questionava a valia de nos referirmos a mapas como representações reais de territórios. Hoje, no senso comum, as rotas determinadas por aplicativos e mapas digitais são tomadas como verdades e pouco se questiona sobre a 'neutralidade' dos mapas e dados georreferenciados disponibilizados, ou mesmo sobre outras formas de se experienciar a realidade e as camadas não captadas por aplicativos. A relevância dos "modelos" em comparação ao real é maior, de maneira que o mapa se torna um simulacro, e a conexão entre a realidade e suas representações se complexifica. A presença dos mapas digitais na palma das mãos passa a ser a primeira leitura de reconhecimento do

91 "It seems as though in the end, maps - the successful ones, the ones that show us where we are and get us from here to there - risk offering only two alternatives. They let us see too much, and hence blind us to what we cannot see, imposing a quiet tyranny of orientation that erases the possibility of disoriented Discovery, or they lose sight of all the other things that we ought to see. They omit, according to their conventions, those invisible lines of people, places, and networks that create the most common spaces we live in today." (KURGAN, 2013, p. 16) 
espaço em que se percorre ou se está. São essas interfaces que trazem os novos signos de entendimento do entorno, abrigando novas abstrações.

Num caráter mais prático, ainda no sentido da abstração agindo no entendimento direto do real, Albarracín Santiago ${ }^{92}$ destaca, em seu artigo 'Towards a new Datascape', como o desenvolvimento e pervasão da internet e do mundo digital mudou relações e comportamentos da sociedade com a cidade. Para o autor, isso acontece devido a três surgimentos que elenca da seguinte maneira: 1- surgimento dos computadores pessoais; 2- surgimento massivo de conexões à internet e 3- surgimento das mídias locativas e redes sociais.
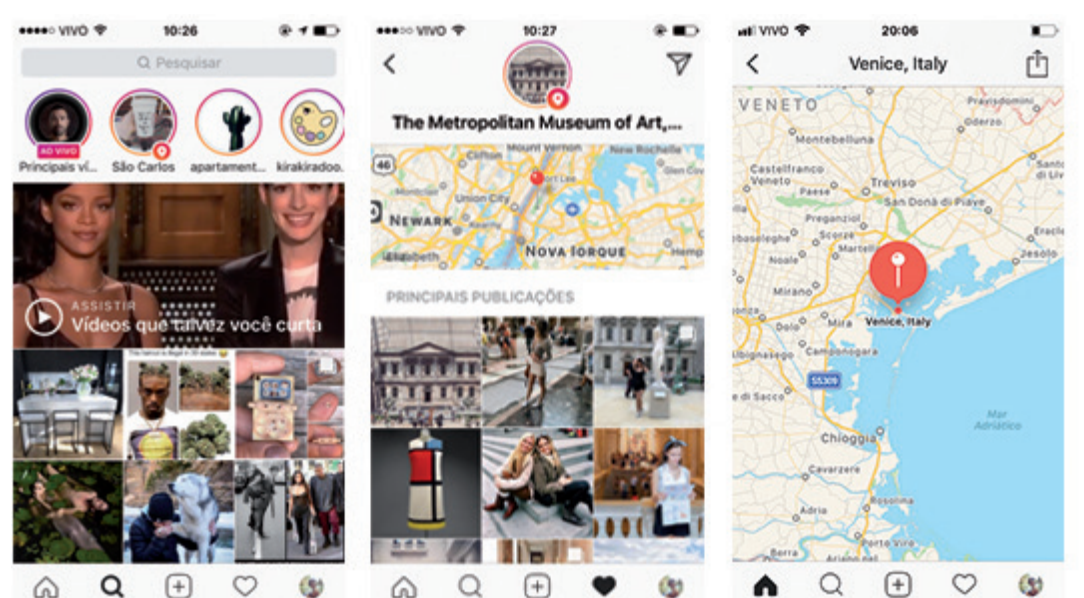

Figura 20- Interfaces do App Instagram. Fonte: Intagram.com

Aprofundando no terceiro item (surgimento das mídias locativas e redes sociais), os aplicativos possuem um grande potencial ao se tratarem de difusores de conteúdo e ainda, segundo o autor, "prontos para transmitir ao mundo todo e interagir com todos seus usuários" (2016, p. 794). Para citar alguns exemplos práticos utilizados por Santiago, temos, o aplicativo Instagram $^{93}$ (Figura 20):

"Quando toda a informação compartilhada no aplicativo é recolhida e despejada em um mapa virtual, os resultados tornam-se muito mais

92 SANTIAGO, 2016)

$93 \mathrm{https} / /$ www.instagram.com | Trata-se de um aplicativo de uma rede social de fotos que permite, a cada foto publicada, saber a localização do usuário, quais os tipos de registros feitos em localizações específicas, conhecer o perfil do usuário, o grau de aceitação daquela informação, dentre outras. 
interessantes, e em alguns casos interativos, porque dentro desses dados estão data e hora que nos dão a possibilidade de criar uma animação"94 (SANTIAGO, 2016, p. 794, tradução nossa).

Podemos citar como exemplo prático disso, que Santiago menciona na citação acima o projeto chamado 'On Broadway' (Figura 21), de autoria de Daniel Goddemeyer, Moritz Stefaner, Dominikus Baur e Lev Manovich. Este é um projeto de visualização de um extenso banco de dados, apresentada na forma de uma instalação interativa. Trata-se de uma compilação de imagens e dados postados com a georreferência da famosa avenida Broadway que atravessa Manhattan (extensão de $21 \mathrm{~km}$ ). Os dados e imagens são provenientes de diversos aplicativos; entre imagens e dados, foi o total de 660.000 fotos do instagram (num período de 6 meses), postagens de imagens no twitter e check ins da Foursquare (desde o ano de 2009), imagens do Google Street View, 22 milhões de leva e traz de táxi (em 2013) e indicadores econômicos do Censo Americano (US Census Bureau).

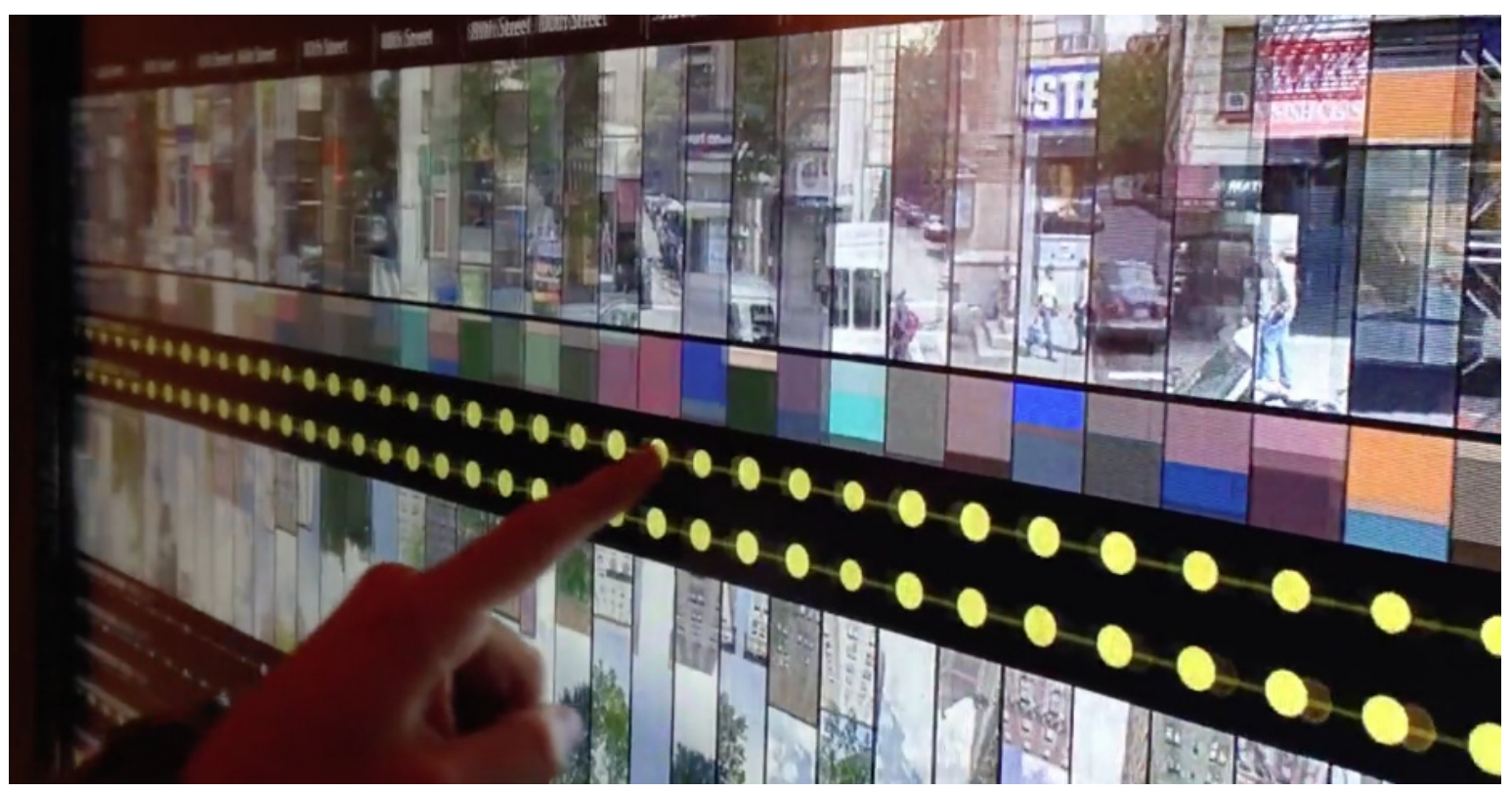

Figura 21- On Broadway- Interface interativa dos dados. Fonte: on-broadway.nyc.

94 “Cuando se junta toda esa información y se la vuelca en un mapa virtual los resultados se vuelven mucho más interesantes, y en algunos casos interactivos, ya que dentro de esos datos figura la fecha y la hora lo cual nos da posibilidad de armar una animación [...]"(SANTIAGO.2016:794) 


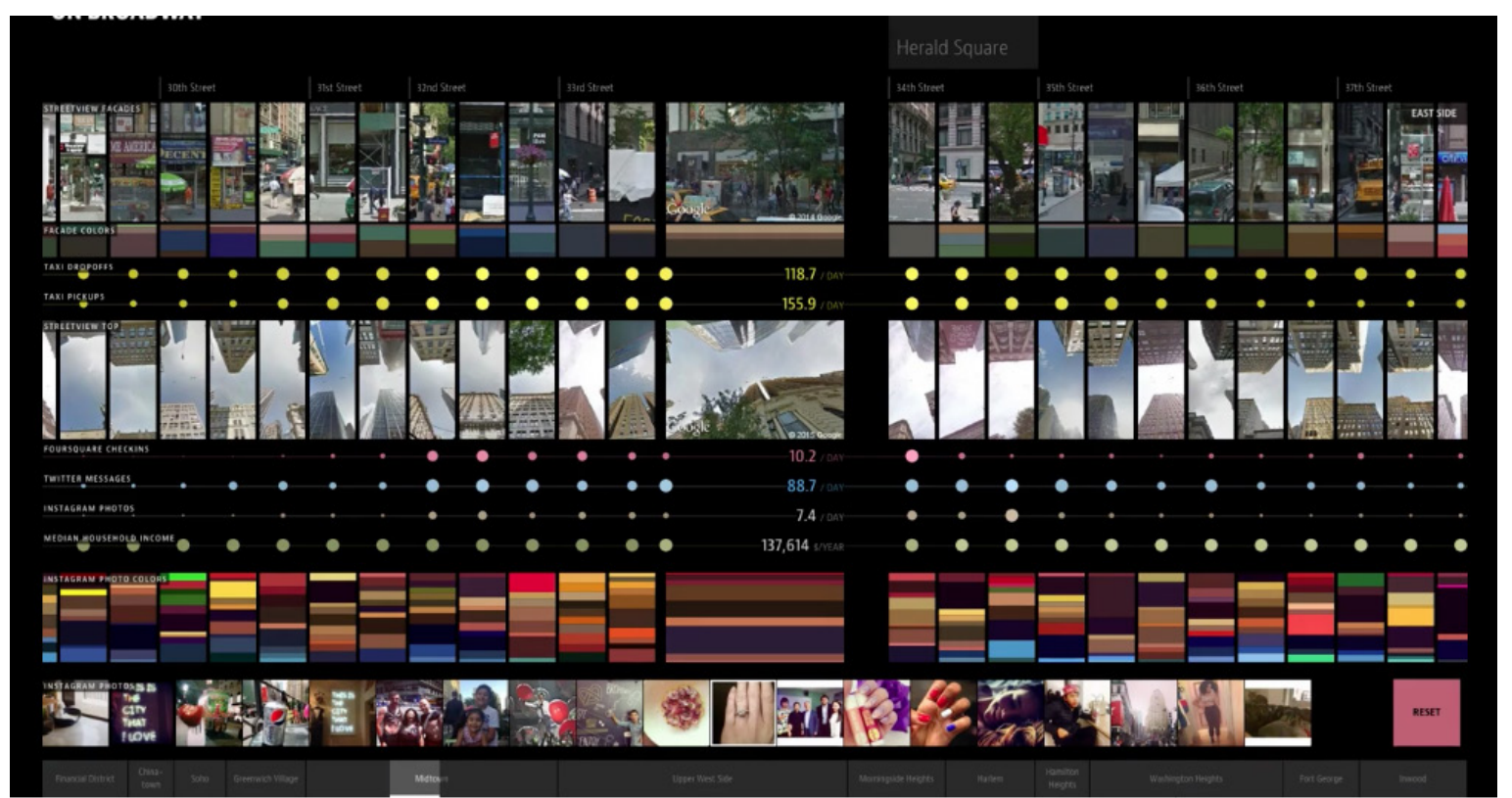

Figura 22- On Broadway- Interface interativa dos dados onde é possível visualizar as 13 camadas informacionais utilizadas no projeto. Fonte: on-broadway.nyc.

A interface do projeto foi organizada em 13 camadas, todas alinhadas a locais ao longo da Broadway (Figura 22). À medida que o espectador seleciona um determinado trecho da rua, ganham destaque uma seleção de fotos Instagram de cada área, as principais imagens do Google Street View, informações de leva e trás de táxis na região, imagens do Twitter, cores predominantes nas imagens relativas ao trecho, dados estatísticos médios econômicos e sociais, e ainda camadas adicionais, como nomes de bairros que cruzam a Broadway e importantes cruzamentos e referências. Ter todas essas informações, ordenadas em camadas de maneira interativa é bastante revelador e torna visível as diferenças, estéticas e sociais, de cada trecho da famosa avenida.

As ações das mídias locativas e seus aplicativos que lidam com informação georreferenciada vão muito além das citadas até agora, que é a troca e criação massiva de dados em tempo real; elas repercutem também nas relações produzidas nas e com as cidades. Sua ação pode ser percebida a contrapelo, quando tais dispositivos revelam suas lógicas e poderes de gestão de milhares de pessoas. Um exemplo recente ocorreu na cidade de São Paulo, em outubro de 2017, com uma falha no algoritmo do aplicativo Waze. Segundo uma reportagem do 
O Estado de S. Paulo ${ }^{95}$, o incidente triplicou a lentidão do trânsito. Segundo os dados da Companhia de Engenharia de Tráfego (CET), já às 14h havia 78,1 km de congestionamento, sendo que a média no mesmo horário costuma ser de $23,4 \mathrm{~km}$. O aplicativo, por alguma falha no sistema, sobrecarregou certos trajetos, enviando centenas de carros para as mesmas vias, causando assim um transtorno urbano. Situação essa que nos alerta para a influência que esse aplicativo, por exemplo, tem no trânsito cotidiano da cidade, ou ainda, para o controle que possui sobre uma cidade inteira.

Há também algumas repercussões que ocorrem a longo prazo. Retomando um exemplo citado por Santiago, temos o Airbnb (Figura 23). O aplicativo causou mudanças sensíveis na distribuição populacional de cidades inteiras, inclusive influenciando economias e mercados imobiliários locais. No aplicativo, usuários alugam casas e apartamentos de outros usuários, e este serviço acabou se tornando mais uma popular maneira de hospedagem temporária de muitos viajantes e turistas.

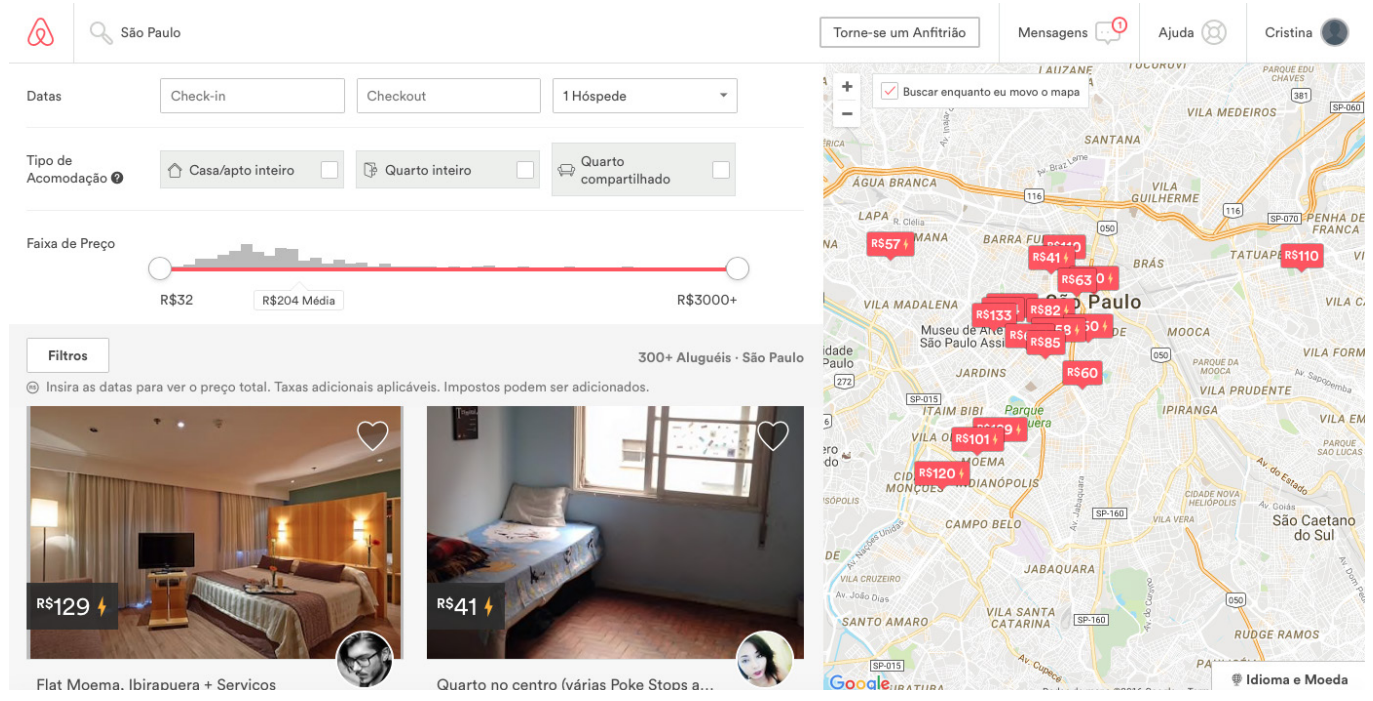

Figura 23- Interface do AirBnB. Fonte: AirBnB

A popularidade do Airbnb cresceu tanto que, devido ao seu baixo preço quando comparado a hotéis/pousadas e ao grande número de opções mundo afora impactou sensívelmente o

95 Notícia escrita por Bruno Capelas, Bruno Ribeiro e Priscila Mengue. Publicada 23 Outubro 2017 http://sao-paulo.estadao.com.br/noticias/geral,com-lentidao-triplicada-sao-paulo-tem-segunda-feira-atipica,70002057753 
mercado imobiliário, o que causou um processo significativo de gentrificação em diversas cidades ao redor do mundo. Segundo Santiago, devido ao valor competitivo de aluguel e da alta procura de usuários do aplicativo, houve um deslocamento por parte de populações locais das áreas centrais para as periferias das grandes cidades, devido ao alto valor imobiliário que as áreas centrais adquiriram.

O que ilustra bem toda essa repercussão descrita é o trabalho de Kor Dwarshuis que criou uma visualização animada de locais disponibilizados no AirBnB desde o ano de fundação da empresa (2008) até o ano de 2017. Conforme corre a linha do tempo, a progressão de pontos brancos ${ }^{96}$ aumenta de forma expressiva. Dwarshuis fez essa visualização de cinco principais cidades do mundo (Amsterdã, Barcelona, Berlim, Nova Iorque e Londres).

Como é possível observar no comparativo abaixo (Figuras 24 e 25), a dominância de imóveis inseridos nesta lógica de rede colaborativa é expressiva e só vem confirmar como esse mercado interfere no deslocamento da população local, e o mercado imobiliário de regiões centrais e valorizadas passa a sofrer grandes alterações e uma hipervalorização local.

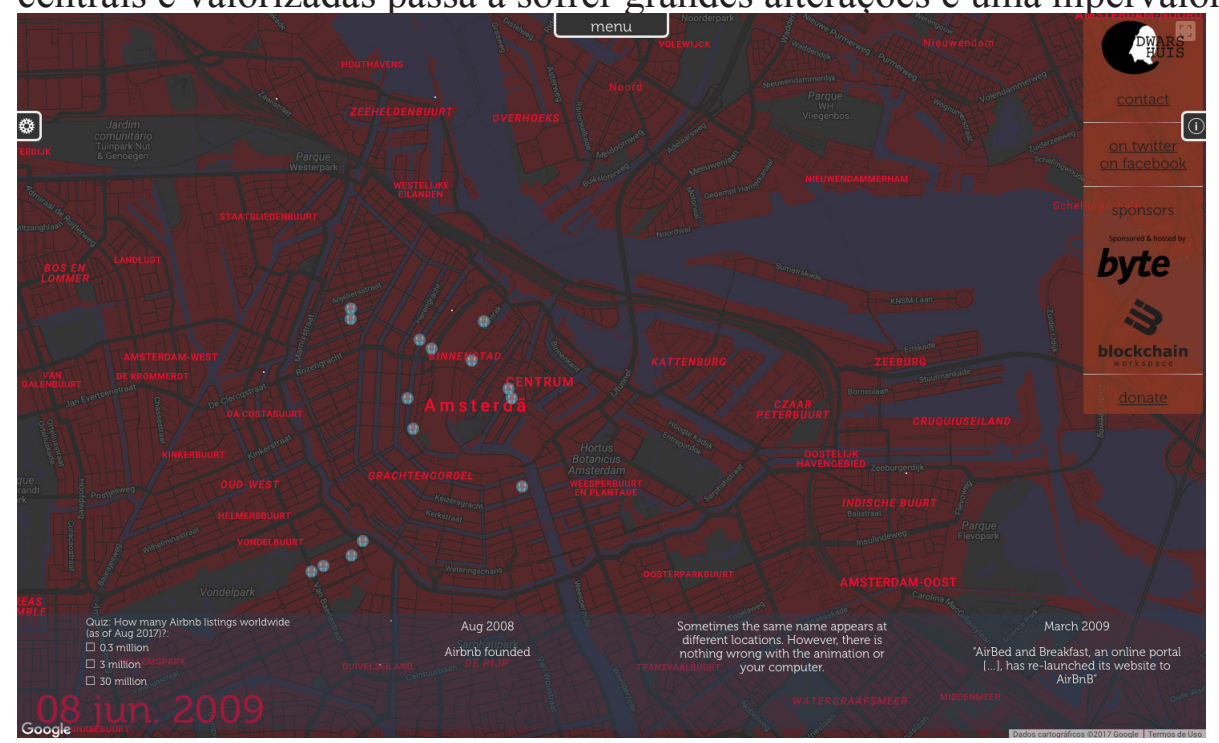

Figura 24- Imagem referente a 8 de Junho de 2009 em Amsterdã. Cada pontinho branco representando um local disponibilizado na rede colaborativa do AirBnB. Fonte: dwarshuis.com

96 Cada ponto branco representa uma nova residência disponibilizada no aplicativo. 


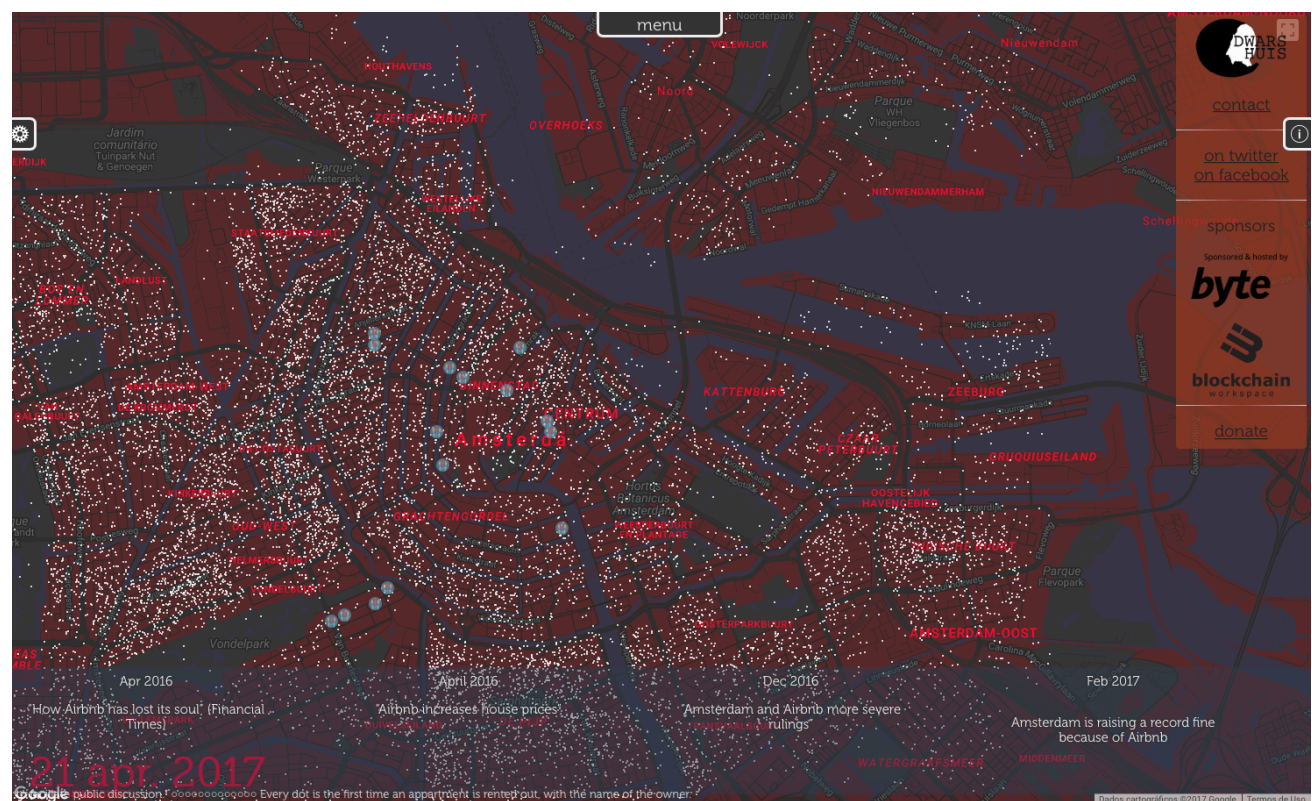

Figura 25- Imagem referente a 21 de abril de 2017 em Amsterdã. Cada pontinho branco representando um local disponibilizado na rede colaborativa do AirBnB. Fonte: dwarshuis.com

É a partir de ações como essas, a gentrificação nas cidades e investimentos audaciosos em parceria com grandes incorporadoras ${ }^{97}$, que se percebe como uma startup, que surgiu de uma incubadora com o objetivo de promover uma plataforma comunitária para pessoas anunciarem, descobrirem e reservarem acomodações, hoje é responsável pela alocação da população local de cidades inteiras, flutuação do mercado imobiliário e ainda movimentação turística pelo mundo.

Nos negócios baseados em "compartilhamento" e "colaboração" que se tornaram grandes empreendimentos, os estudos e investimentos em cruzar, mapear e manejar dados são a grande e constante prioridade. Empresas como AirBnB possuem equipes inteiras dedicadas a entender e conseguir extrair ao máximo os dados do colaborador, do cliente e das regiões que

97 E ainda como repercussão deste cenário econômico, foi anunciado em outubro de 2017 mais um ambicioso avanço da empresa. O AirBnB, em parceria com uma grande incorporadora imobiliária de Miami, construirá um prédio de 324 apartamentos que levará o nome AirBnB. Os donos dos apartamentos desse prédio serão encorajados a disponibilizarem seus apartamentos para locação no aplicativo, e os hóspedes terão acesso a comodidades típicas hoteleiras (concierge, serviço de faxina, armazenamento de bagagem). O foco da empresa está nas cidades de grandes visitações, mas que costumam oferecer um preço muito alto de aluguel. O primeiro complexo será na Flórida, previsto para ficar pronto em 2018. 
atuam. O blog da própria empresa, que é especificamente dedicada a esse assunto 'Airbnb Engineering \& Data Science ${ }^{98}$, divulga periodicamente estudos e avanços relacionados ao desenvolvimento da engenharia informacional envolvida. Em janeiro de 2015, por exemplo, foi anunciada a elaboração de uma nova ferramenta interna, que tem como propósito mapear o mundo. No entanto, não o mapeamento usual que costumamos ver em outras plataformas (de ponto a ponto), mas um mapeamento de região a região.

Em outras palavras, um mapeamento complexo que conta com o cruzamento muito maior de informações. A intenção dessa ferramenta é tentar entender o que faz o usuário preferir uma região a outra. Entender os elementos que influenciam a tomada de certas decisões. O estudo conta, segundo a postagem no site, desde a criação de novos algoritmos a recomendações e impressões de pessoas locais.

“A localização é um elemento fundamental para uma série de nossos esforços de engenharia. Nossa equipe precisa ajudar o viajante Airbnb a mitigar sua preocupação número um ao encontrar um lugar para ficar: localização. Por outro lado, queremos destacar as mais diversas listas oferecidas pelos anfitriões da Airbnb em todo o mundo." 99 (SHOFF, 2015, s/n, tradução nossa)

É, portanto, perceptível, já com apenas alguns desses exemplos, o potencial que aplicativos utilizados com dados georreferenciados possuem. Os aplicativos conectados a GPSs demarcam onde qualquer um em posse de um dispositivo esteve, irá, frequenta, horários e períodos em cada coordenada e, com isso, até prever futuras atividades do usuário ou até mesmo de massas de pessoas. São muitas as informações que podem ser geradas por um indivíduo. Considerando ainda que apenas uma pessoa, por exemplo, utiliza inúmeros aplicativos (serviços, entretenimento, consultas, etc) que compõem o seu cotidiano. Além das informações que são geradas de input nos aplicativos, as que são geradas por opportunistic

\footnotetext{
$98 \mathrm{https}: / /$ medium.com/airbnb-engineering
}

99 "Location is a crucial building block for a number of our engineering efforts. Our team needs to help the Airbnb traveler mitigate their number one concern when finding a place to stay: location. On the flipside we want to highlight the million-plus unique listings opened up by Airbnb hosts around the world" 
sensing e também uma grande quantidade que é consumida.

Como exemplo significativo recente desse modo de funcionamento, deve-se atentar para o caso Strava que revelou de dados de segurança militar americana, que ilustra bem como uma leitura atenta dos aplicativos de geolocalização e um cruzamento simples informacional pode ser revelador.

O aplicativo Strava, que é conhecido como 'redes sociais de atletas', incentiva e marca atividades físicas executadas pelo usuário em posse de um smartphone ou smartwatch. Nesse aplicativo, além de acompanhar o rendimento (velocidade, batimento cardíaco, tempo, calorias gastas, etc) durante exercícios físicos, é possível postar e disponibilizar os locais e as trajetórias dos treinos geolocativamente, tanto para compartilhar com demais participantes da própria rede Strava como das demais redes sociais (Facebook, twitter, etc). É um aplicativo que já possui dezenas de milhões de usuários, muito popular entre

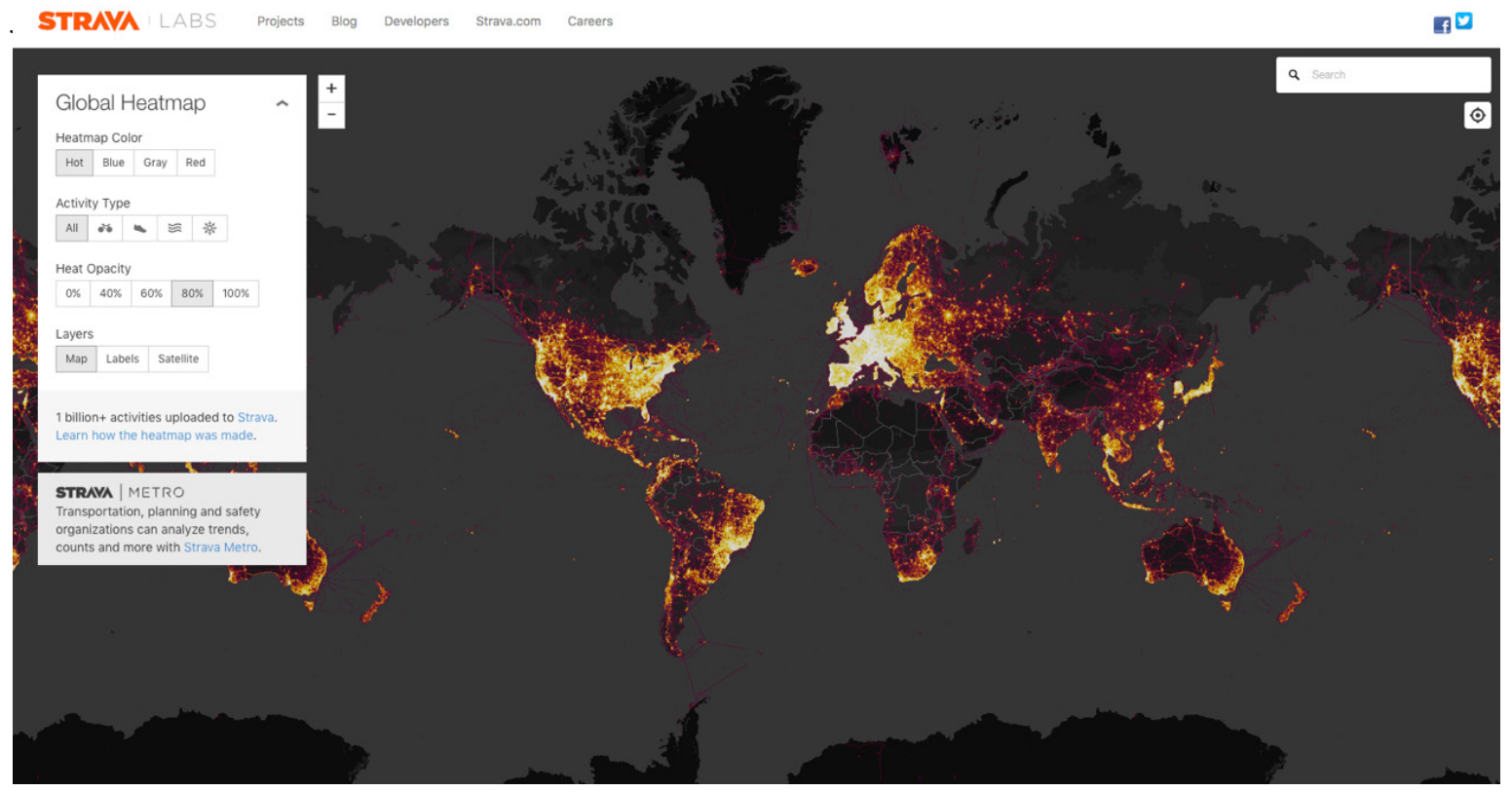

Figura 26- Interface do mapa de calor divulgada pelo App Strava. Fonte: labs.strava.com

A Strava disponibiliza um mapa de calor ${ }^{100}$ (heat map-Figura 26) em que demarca as atividades 100 https://labs.strava.com/heatmap/\#2.00/-38.13148/22.96881/hot/all 
de seus usuários. No entanto, foi observando atentamente esse mapa, que Nathan Ruser (20 anos), um estudante australiano de análise de segurança, percebeu que as informações lá expostas apontavam uma séria falha de segurança. Nele era possível observar atividades e trajetos de treinamentos de soldados militares. Essas demarcações, não só apontavam claramente bases militares (Figura 27), mas rotas que soldados adotam entre uma base e

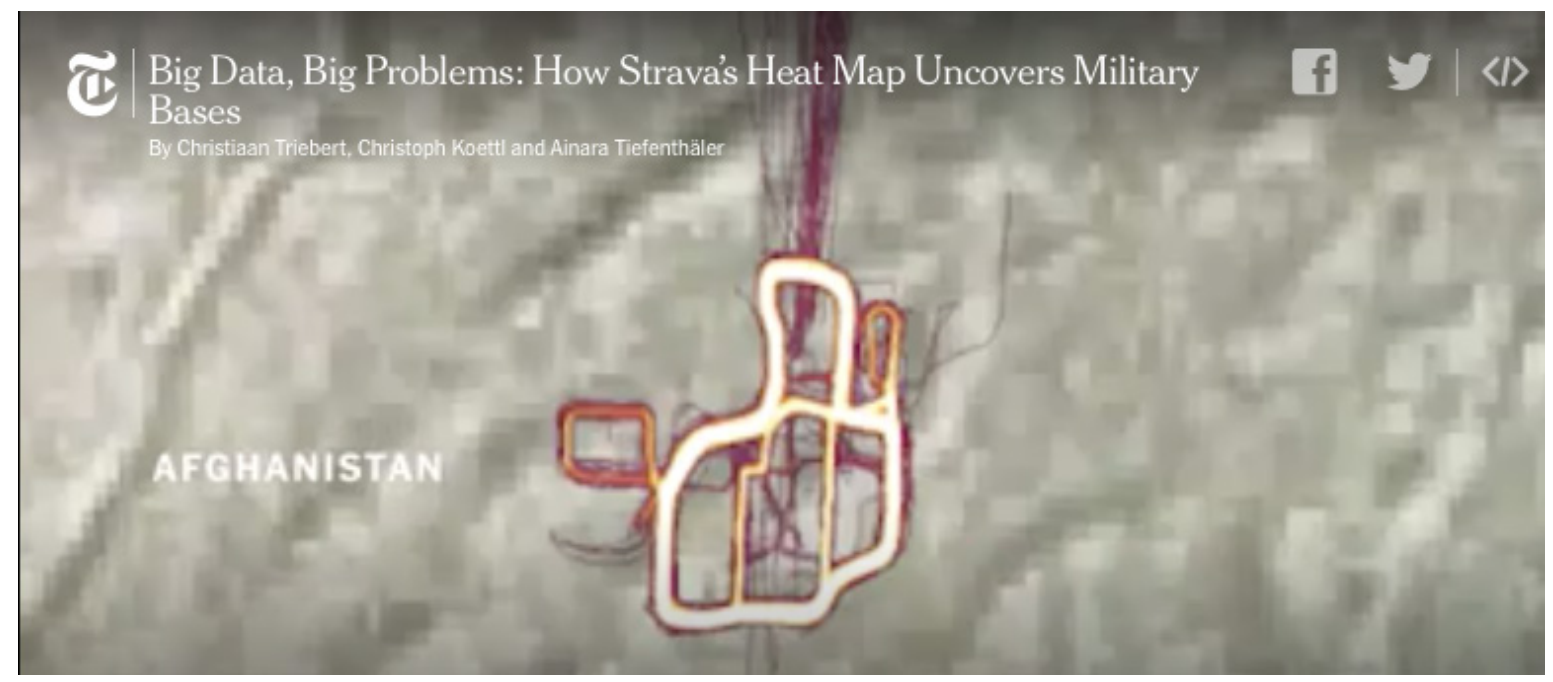

Figura 27- Marcação em uma base militar no Afeganistão. Fonte: NYTimes vídeos.

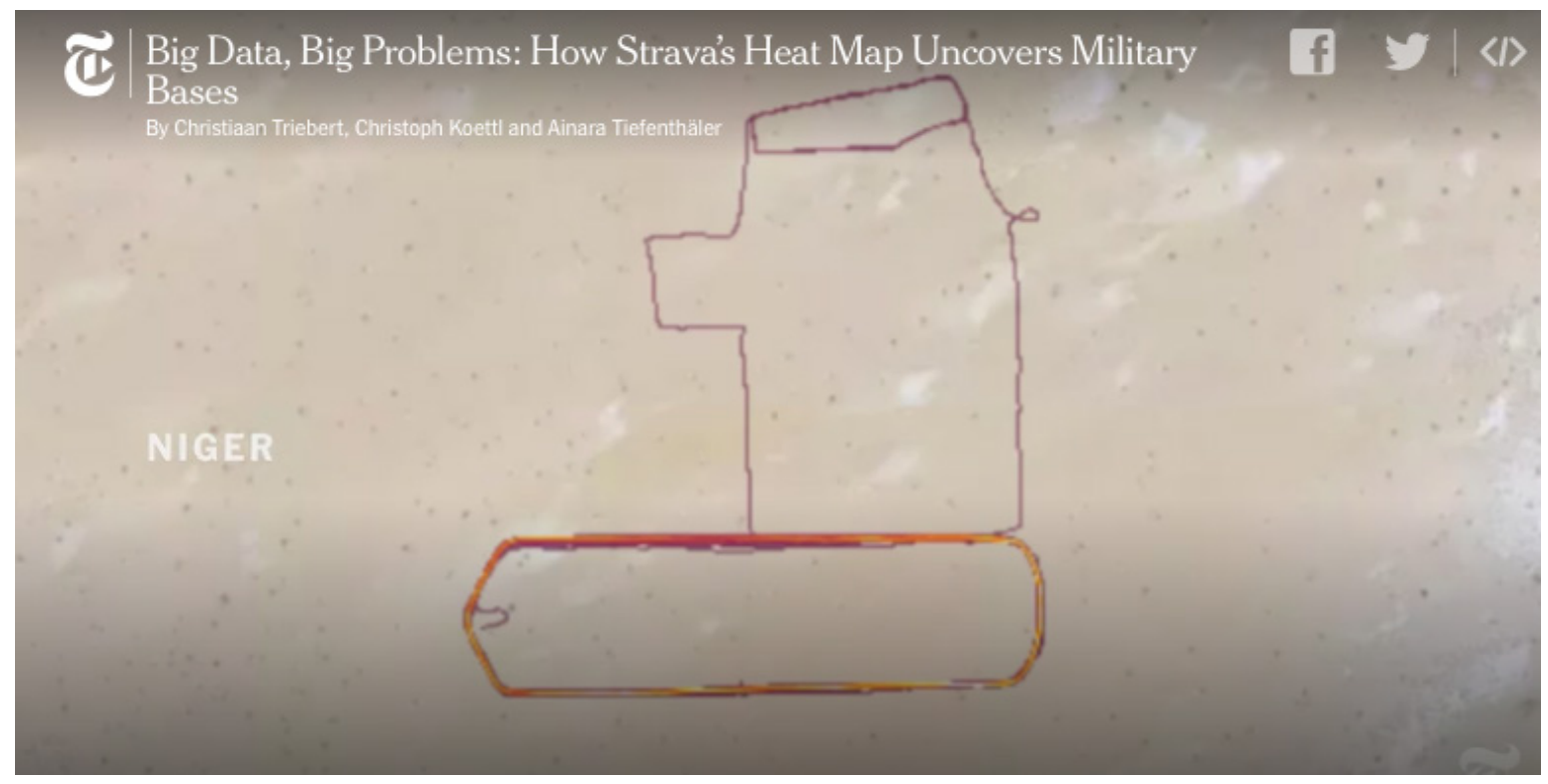

Figura 28-Marcação emmeio ao deserto da Nigéria. Onde se desconhece de qualquerbase ou acampamento militar. Fonte: NYTimes vídeos. 
Apesar de o mapa fornecido por Strava não ser dos mais atualizados, é possível cruzar as coordenadas e perceber do que realmente se trata. Inclusive foram detectadas atividades em meio a desertos e lugares inóspitos em que se desconhecia publicamente qualquer tipo de atividade militar (Figura 28). Tais informações podiam ser verificadas a partir das postagens de fotos e selfies pessoais (Figura 29) compartilhadas pelos próprios soldados que traziam ainda outras camadas de informação dos arredores.

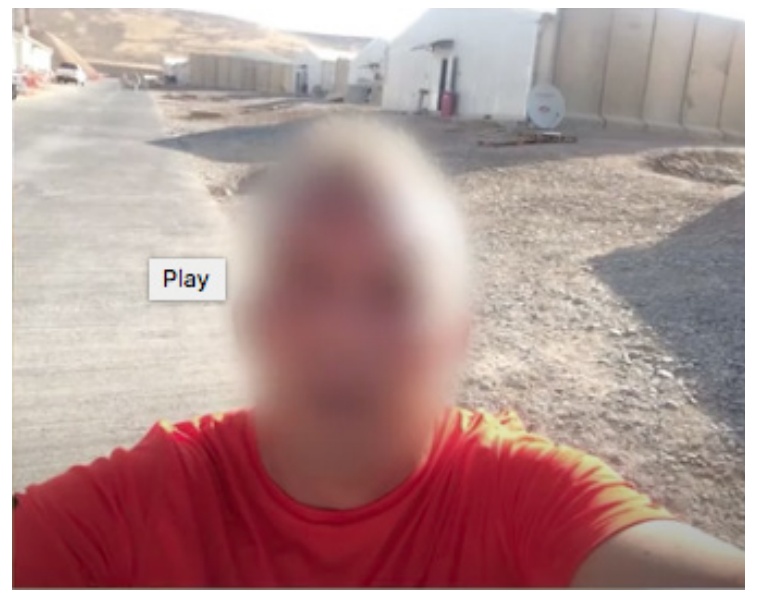

Figura 29-Selfie tirada por um soldado americano após o treinamento. A base militar pode ser vista ao fundo. Fonte: NYTimes vídeos

O estudante que descobriu a falha prontamente apontou-a via Twitter (Figura 30) e, em questão de pouco tempo, surgiram inúmeros alertas de outros analistas de segurança, que confirmaram a falha encontrada, seguidos de questionamentos por parte da mídia. Na matéria do New York Times (Strava Fitness App Can Reveal Military Sites, Analysts Say ${ }^{101}$ ) escrita por Richard Pérez-Penã e Matthew Rosemberg, publicaram que como resposta à situação uma porta-voz do pentágono declarou que o Departamento de Defesa recomenda aos seus soldados que limitem a privacidade de suas mídias sociais e que iriam rever a questão. A CIA (Central Intelligence Agency) nada declarou, e a própria empresa do aplicativo, Strava, baseada na Cidade de São Francisco (E.U.A.) declarou em seu blog que é possível pelos ajustes do aplicativo deixar as informações no modo privacidade e, assim, a atividade não se tornaria pública, bem como não contabilizada no mapa geral.

101 Publicada dia 30 de janeiro de 2018. Fonte: https://mobile.nytimes.com/2018/01/29/world/middleeast/strava-heat-map.html?smid=fbshare\&referer=http://m.facebook.com 
Nathan Ruser

@Nrg8000

Strava released their global heatmap. 13 trillion GPS points from their users (turning off data sharing is an option). medium.com/strava-enginee... ... It looks very pretty, but not amazing for Op-Sec. US Bases are clearly identifiable and mappable

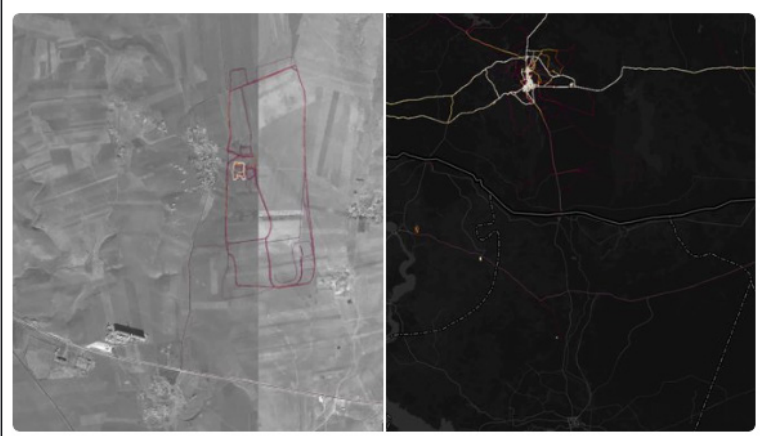

4:24 PM $\cdot 27$ de jan de 2018
Figura 30- Postagem no Twitter do estudante ao descobrir a falha de segurança no mapa de calor de Strava.

Fonte: www.Twitter.com

Alguns anos antes, uma interface baseada em mapas já havia explicitado aspectos problemáticos da coleta e espacialização de dados geolocativos. Desenvolvida pela empresa Ubisoft em 2013 para uma campanha de marketing de um jogo em plataforma digital, We are Data ${ }^{102}$-Watchdogs (Figura 31) tinha como base as cidades de Londres, Berlim e Paris. Diferentemente dos mapas digitais comuns de cidades, estes eram atualizados em tempo real com as mais diversas bases de dados de grandes e conhecidos aplicativos como Instagram, Twitter, Foursquare, além de outras informações geolocativas de acesso público como de transporte coletivo, caixas eletrônicos, pontos de Wi-Fi disponíveis e entre outros.

Um mapa que mostra a informação dos habitantes das respectivas cidades e suas atividades e redes sociais (Figura 32). Era possível observar em tempo real onde, por exemplo, havia uma grande concentração de usuários twittando, quais as fotos estavam sendo compartilhadas pelo Instagram em algum ponto específico da cidade, quantas bicicletas estavam disponíveis, 


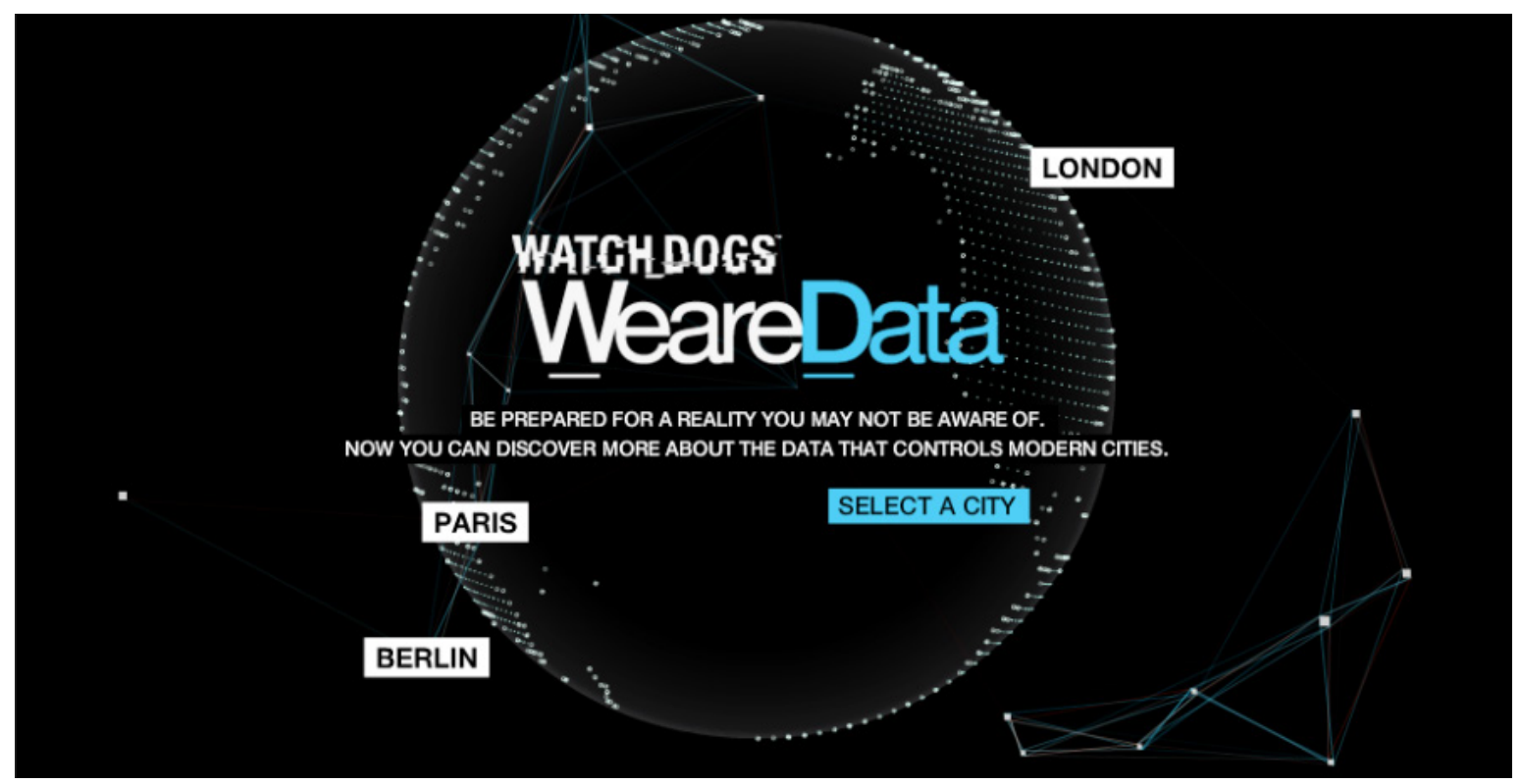

Figura 31- Site oficial da campanha. Fonte: we are data

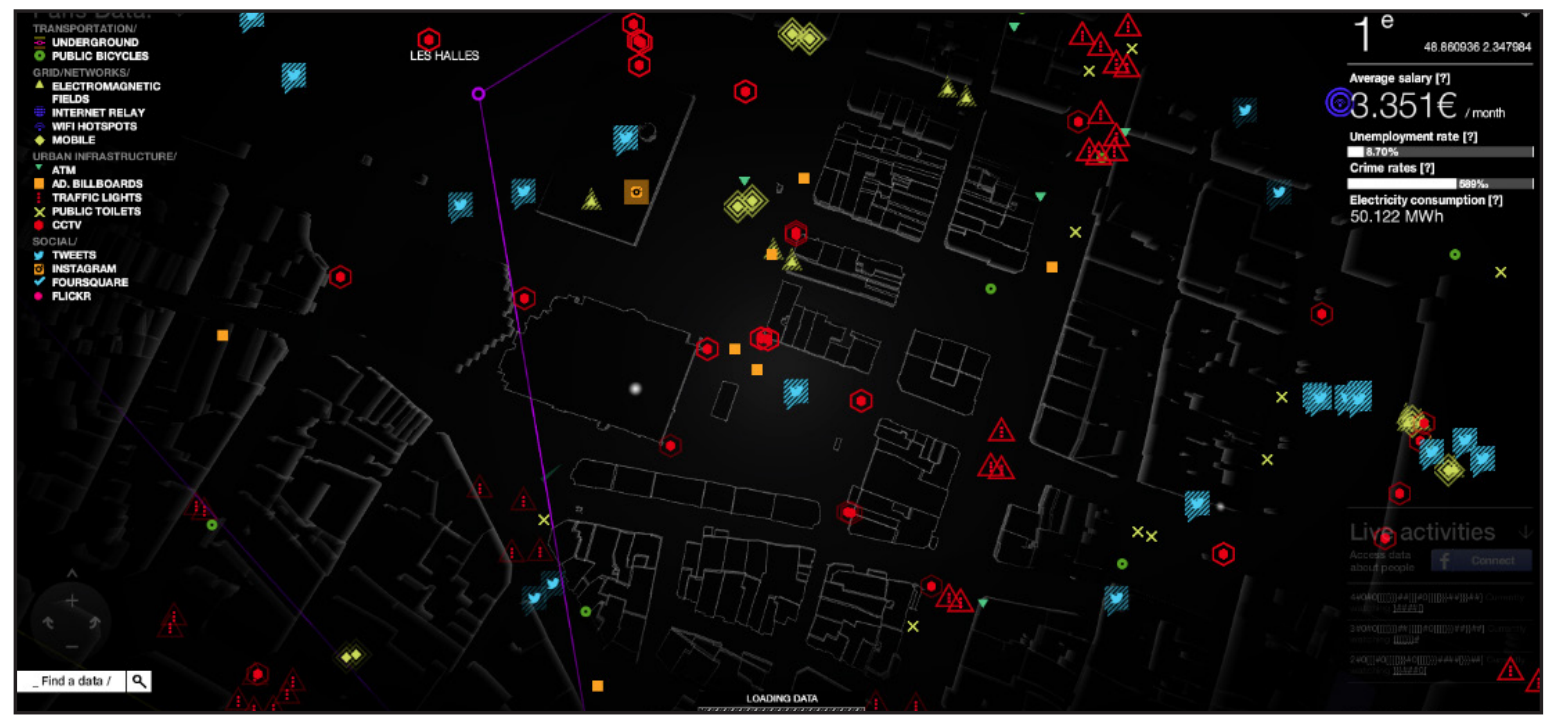

Figura 32- Mapa de Paris com suas demarcações de informações sendo alimentadas em tempo real.

Fonte: we are data

dentre tantas outras informações possíveis (Figuras 33 e 34).

$\mathrm{O}$ que era para ser uma campanha criativa de marketing de um jogo se tornou um mapa completo dessas cidades, que escancarou como as informações que compartilhamos via 
mídias locativas/redes socias são complexas e abertas ao mundo. Muitos foram os artigos na internet suscitados pelo complexo mapa da campanha de marketing. Os mapas hoje estão fora do ar, devido ao encerramento da campanha, mas abaixo seguem imagens de como era sua interface, retiradas de seu site oficial que continua online.

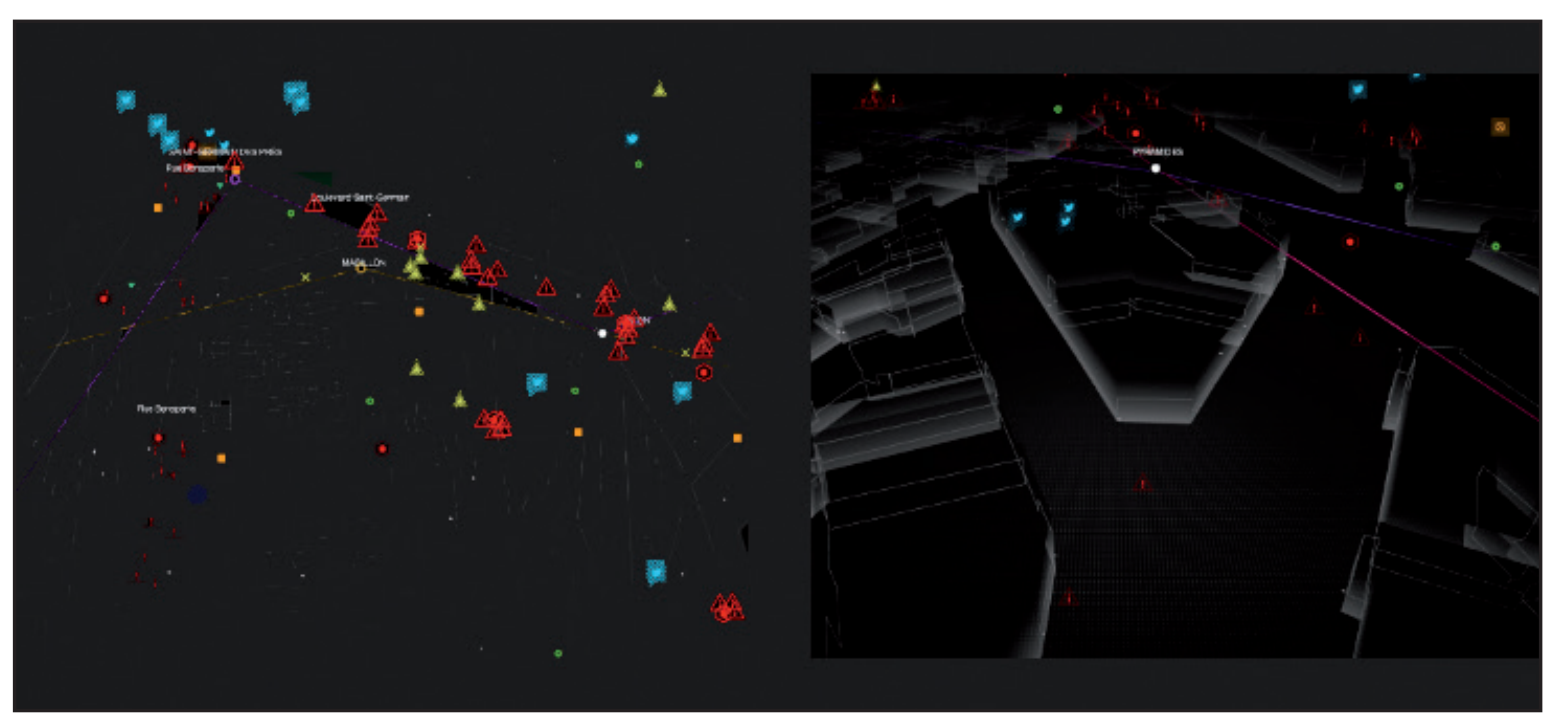

Figura 33- Os dois modos de visualização do mapa de Paris com suas demarcações de informações alimentadas em tempo real (Zoom). Fonte: we are data.

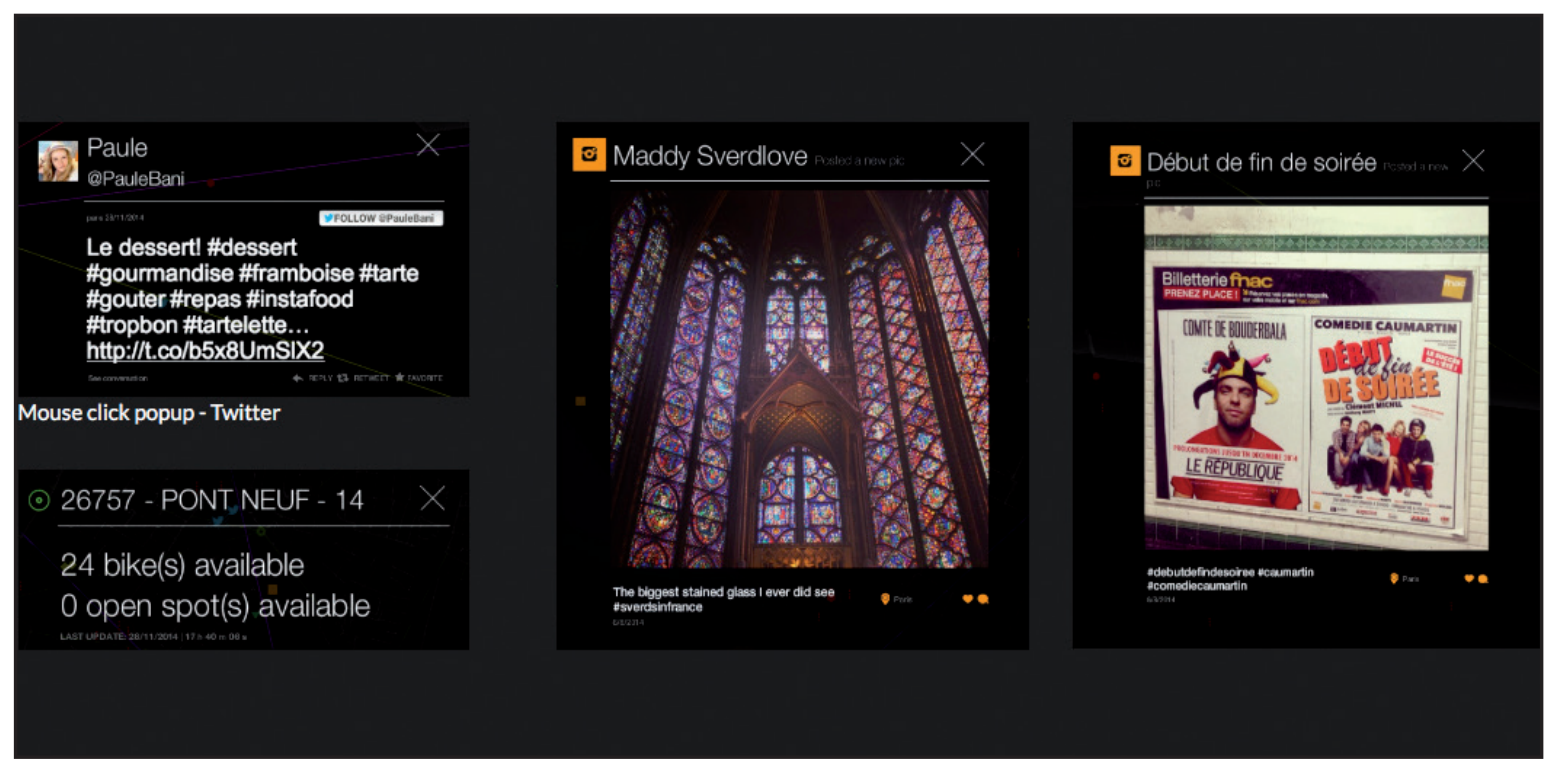

Figura 34- Informações compartilhadas em redes sociais de usuários em Paris. Fonte: we are data 
A presença desse tipo de mediação por meio de mapas colaborativos já extrapola o universo de redes sociais e serviços, chegando inclusive ao entretenimento ou até mesmo às redes de relacionamentos. No Pokemon Go, um jogo online em que o usuário joga em primeira pessoa interagindo com o meio e outros jogadores mediado com o celular, a interação acontece em tempo real - no sentido em que a geolocalização do usuário e seu deslocamento são fundamentais para a premissa do jogo, fato que na época de seu lançamento, causou uma
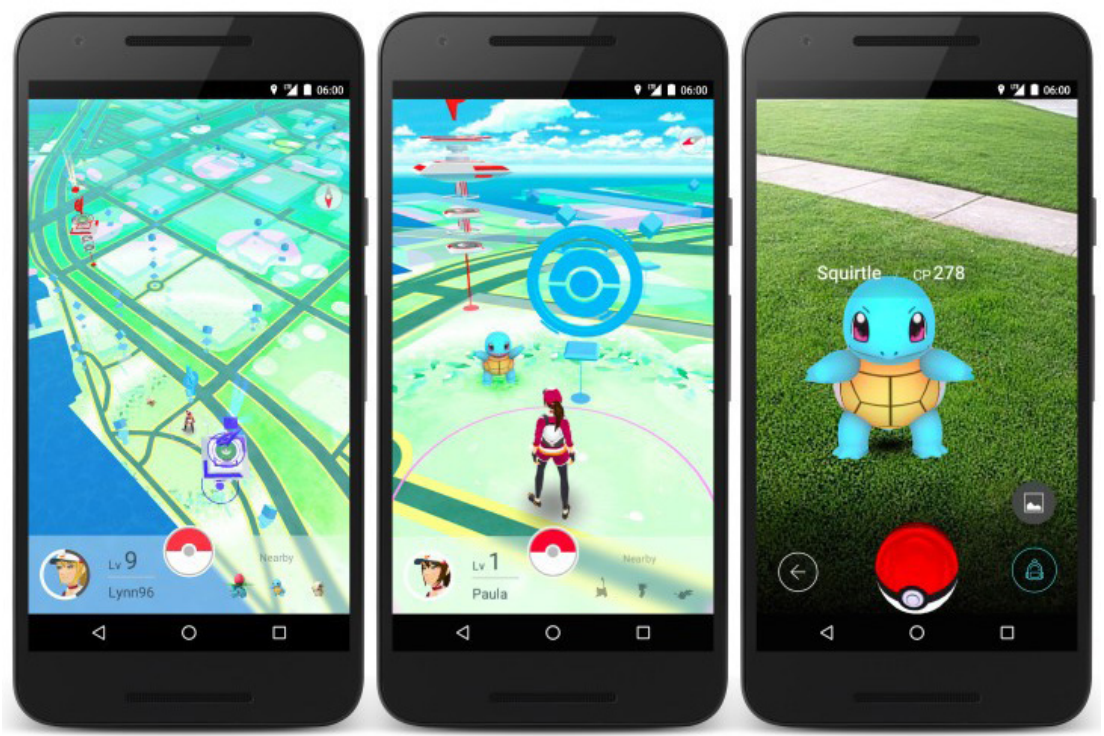

Figura 35- Interface do jogo Pokemon Go. Mapas digitais que localizam os personagens a serem 'caçados' a partir da localização em tempo real do usuário. Fonte: Convertize

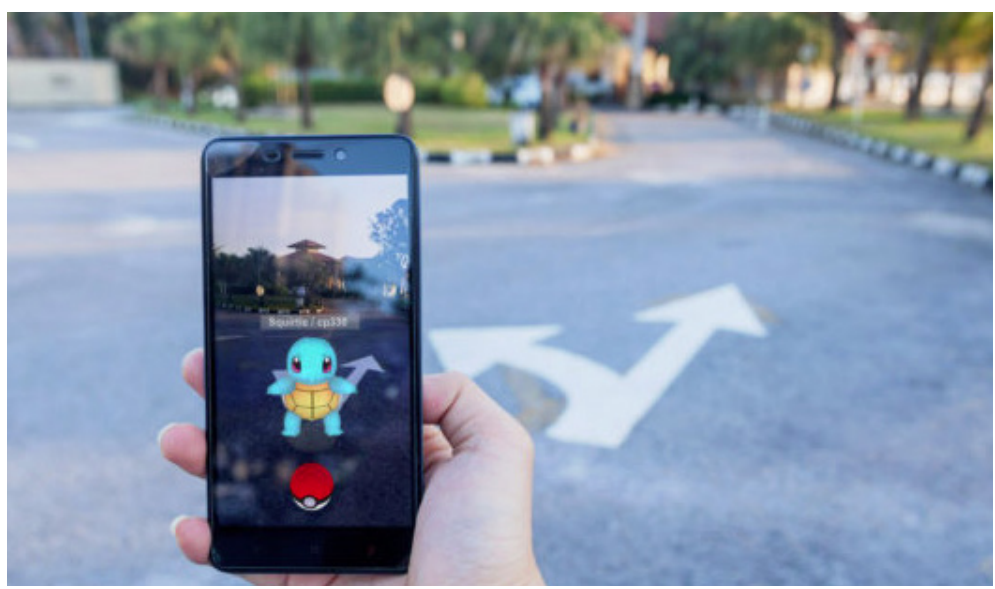

Figura 36- Personagem localizado por mediação do celular.

Fonte: Pokemon Go 


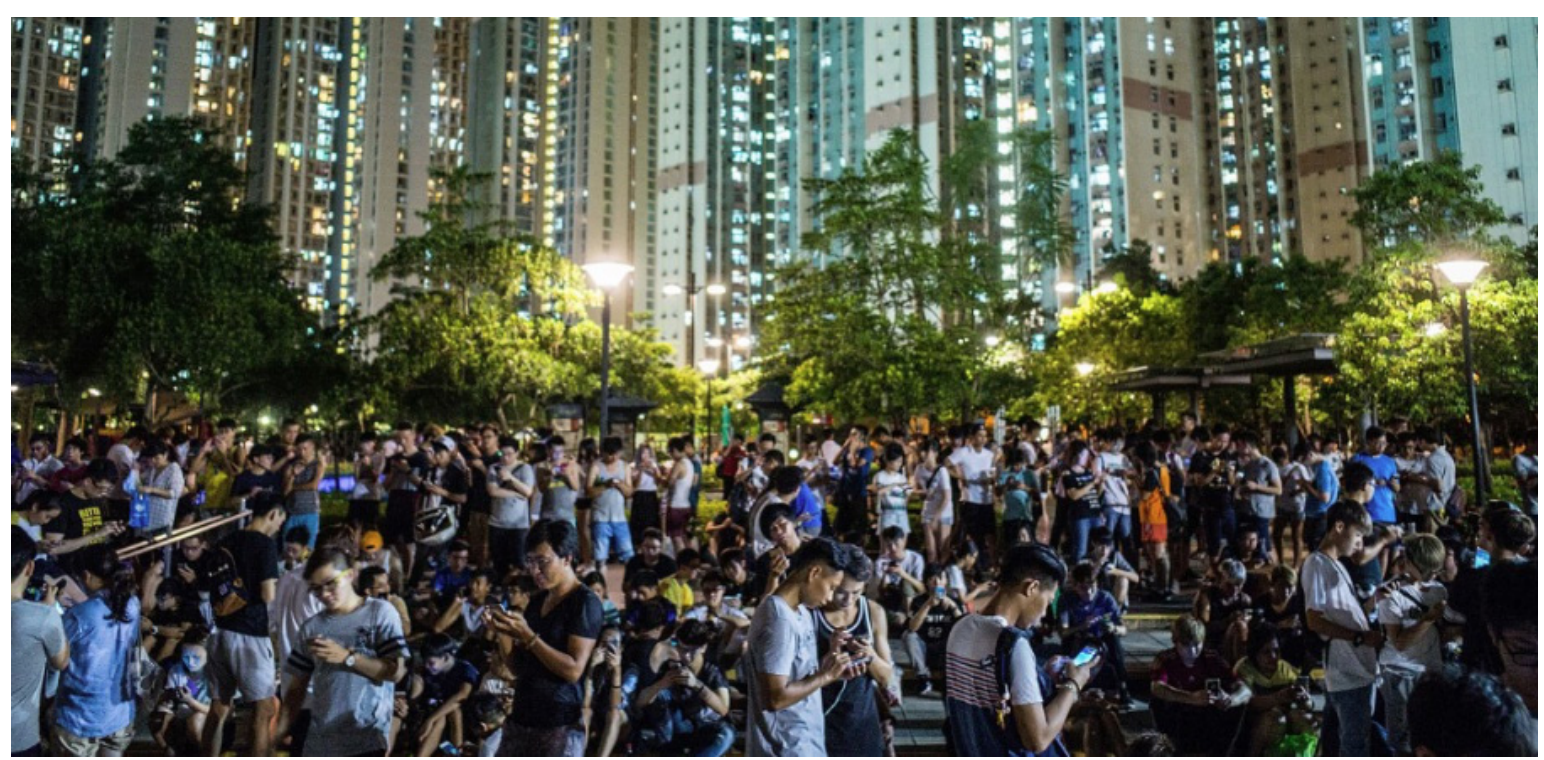

Figura 37- Aglomerados de usuários do jogo Pokemon Go Fonte: CNN

movimentação incomum em uma série de pontos das cidades (Figuras 35 e 36).

As pessoas se aglomeravam em pontos da cidade determinados pelo jogo para cumprir tarefas e galgar níveis acima de pontuação no jogo, além, é claro, de 'caçar' Pokémons que apareciam nos mais diversos locais. O desenvolvimento dos personagens 'caçados' se dava conforme o deslocamento do usuário registrado pelo GPS do jogo, o que modificou a relação do usuário com a cidade (Figura 37).

Apesar de toda a movimentação de pessoas nas cidades, as incidências desses pontos (Pokestops) eram mais presentes em áreas centrais das cidades, enquanto que em regiões periféricas, rurais e de baixa renda, os pontos eram quase nulos (Figura 38). Esse desequilíbrio na distribuição dos pokestops foi constatado em diversos países, o que levou alguns a refletirem o que essa desigualdade de ofertas de participação no jogo reflete sob os aspectos econômicos e políticos por trás desse jogo.

$\underline{\mathrm{Na}}$ reportagem $^{103}$ 'Por que os pontos de interesse de Pokémon Go são distribuídos de 
maneira desigual' da repórter Ana Freitas para o Nexo Jornal, afirma-se que "o mapa do jogo é um reflexo da desigualdade de ocupação das cidades" (2016, s/n) e critica o fato de não haver possibilidade de o usuário sugerir novos pontos. Esses tópicos também se tornaram recorrentes em fóruns de discussão sobre games.

Após esses breves casos de como essas plataformas de mapas colaborativos atuam no cotidiano atual, fica evidente que as colaborações nesses mapas vão muito além de uma relação 'peer to peer', ou melhor, de ajuda mútua entre usuários. Há toda uma complexidade de dados e georreferências que abrigam importantes questões políticas, sociais, econômicas maneira-desigual-na-cidade . Publicado em 10 de agosto de 2016.
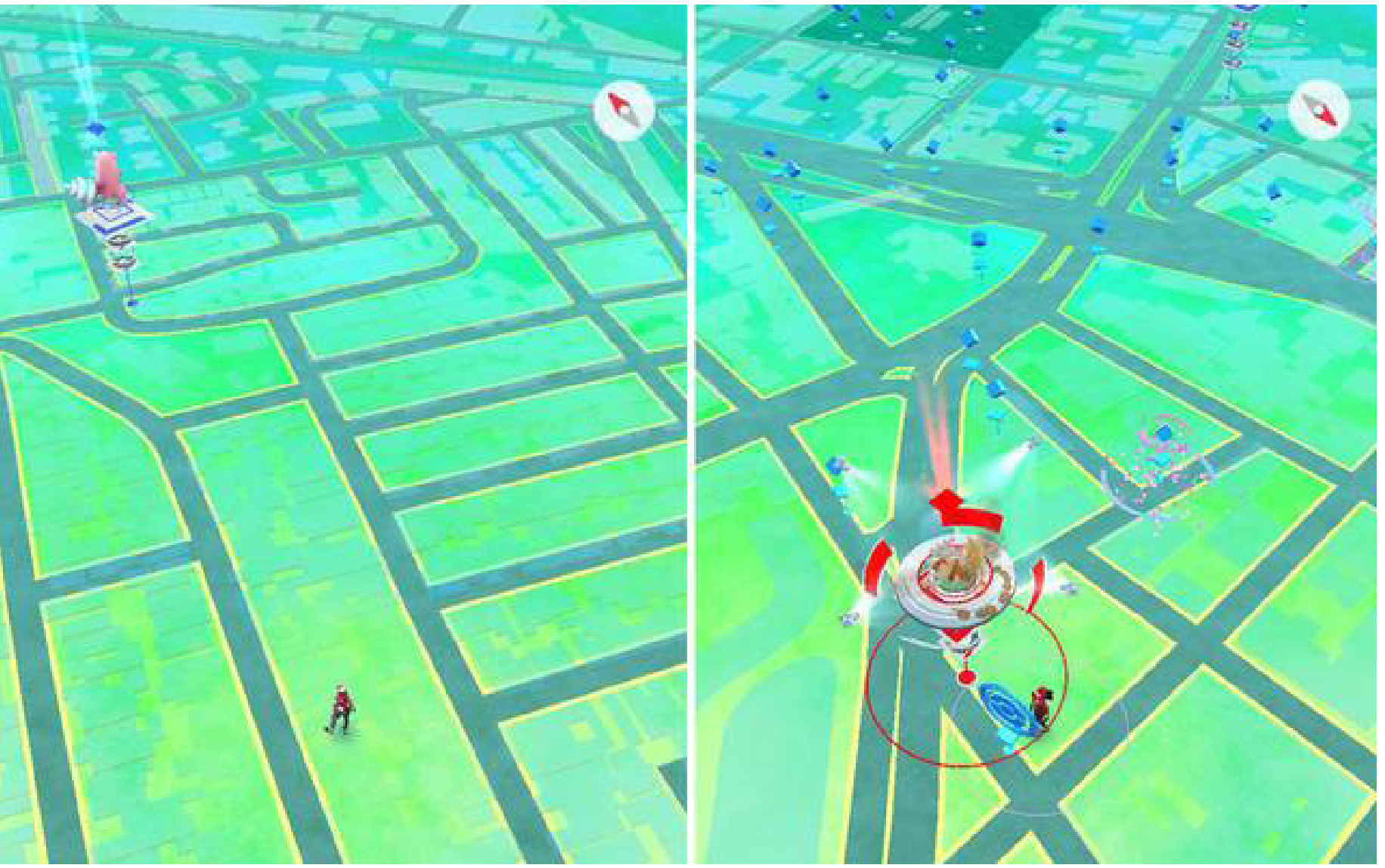

Figura 38- Contraste de concentração de Pokestops entre duas regiões diferentes na cidade de São Paulo. O mapa do lado esquerdo é da Vila Ema (Zona Sul de São Paulo); o mapa do lado direito é do centro de São Paulo. Fonte: Nexo Jornal 
e culturais, que devem ser cada vez mais consideradas.

\subsection{CONTRACARTOGRAFIAS ATIVISTAS}

Que os mapas colaborativos pervadiram de maneira sensível a vivência e o senso de localização do homem contemporâneo já está evidente. Além disso, fica claro que não se trata somente de uma localização geográfica quando mencionamos os mapas atuais, mas de uma localização cultural, econômica e política. Uma vez visíveis essas diversas camadas de leituras presentes em qualquer mapa digital, plataformas como essas passam a ser utilizadas por grupos/coletivos ativistas. São eles os contracartógrafos, cuja postura presente neste tipo de ação resgata a citação de Holmes:

"Cartografias críticas e dissidentes surgem contra o fundo da tecnologia dos mapeamentos dominantes. Elas aparecem como contracondutas ${ }^{104}$ no sentido dado por Michel Foucault." (Holmes, 2006, p. 25, tradução nossa).

Brian Holmes, ativista que indica um embate entre contracartografias e as cartografias dominantes e hegemônicas, ressalta como as relações com o entorno realmente se alteram à medida que a internet pervade a vida do homem contemporâneo. Fica impossível negar o quanto os mapas colaborativos interferem diretamente na interação com outros indivíduos e com a cidade. Holmes afirma ainda que: "As redes tornaram-se as estruturas dominantes do poder cultural, econômico e militar. No entanto, esse poder permanece em grande parte invisível"105 (HOLMES, 2006 ,p. 20, tradução nossa)

Mesmo antes dos mapas digitais, esse "poder que permanece invisível” mencionado por Holmes sempre existiu, sempre houve o binômio importante a ser considerado ao longo das leituras cartográficas do visível e não-visível. E é justamente nessa chave informacional, nos

104 Para Foucault 'contracondutas' refere-se a um sentido ativo “[...] de luta contra os procedimentos postos em prática para conduzir os outros.” FOUCAULT, M. Segurança, Território, População: Curso dad no Collège de France (1977-1978). São Paulo: Martins Fontes, 2008.

105 "Networks have become the dominant structures of cultural, economic and militar power. Yet this power remains largely invisible." (HOLMES, 2006,p. 20) 
esforços de trazer visibilidade ao que é omitido, que os contracartógrafos trabalharão com os mapas digitais ou mapas colaborativos. A possibilidade de ver o planeta do espaço em fotos de satélite (processo já abordado no item 1.2), por exemplo, já havia chamado a atenção inclusive dos ativistas como uma linguagem possível de vinculação informacional - de uma modalidade de representação de suas lutas. Segundo Laura Kurgan:

"Os ativistas reconheceram o poder da imagem para explorar e publicizar os derrames de petróleo e incêndios, despejos de resíduos tóxicos, os efeitos da irrigação, o dano da chuva ácida na floresta, o desmatamento tropical na Amazônia, o encolhimento dos lagos e dos mares, os icebergs ou simplesmente a vulnerabilidade da Terra como uma pequena bola de gude azul, flutuando no espaço." ${ }^{106}$ (KURGAN, 2013, p. 113, tradução nossa)

Essa maneira de representar e localizar ações, intenções e movimentações no mapa permitiu aos grupos ativistas uma outra maneira de expressar suas reivindicações e recursos. Assumindo a qualidade de qualquer cartografia trazer uma forma visual de confrontar aspectos de visibilidades e invisibilidades de informação, coletivos e agentes sociais passam a recorrer a mapeamentos colaborativos para evidenciar confrontos e campos de disputas, por meio de cruzamentos de informações ou evidenciando camadas de leituras desconhecidas.

Ações como estas, de utilização da cartografia como uma forma de contestação, de abalar as relações de poder e processos cartográficos do senso comum, assumem uma postura contracartográfica. Muitos são os grupos ativistas que fazem uso de mapas colaborativos para difundir recursos ou para trazer à tona alguma denúncia.

Há, além do Google, grupos e organizações que se ocuparam em criar mapas com conjunto de dados espaciais abertos justamente para serem utilizados em criação de mapas colaborativos que tenham a finalidade que os grupos ativistas procuram. Apesar de personalizarem e

106 "Activists recognized the power of the image to explore and publicize oil spills and fires, toxic waste dumps, the effects of irrigation, acid rain damage to forest, tropical deforestation in the Amazon, shrinking lakes and seas, calving icebergs, or quite simply the vulnerability of the Earth as a small blue marble, floatingin space." (KURGAN, 2013, p.113) 
adaptarem certas ferramentas para um uso específico, não há uma diferença significativa visual e operacional. Os dois exemplos mais conhecidos de grupos que desenvolvem mapas colaborativos para grupos que querem denunciar ou evidenciar questões sociopolíticos são

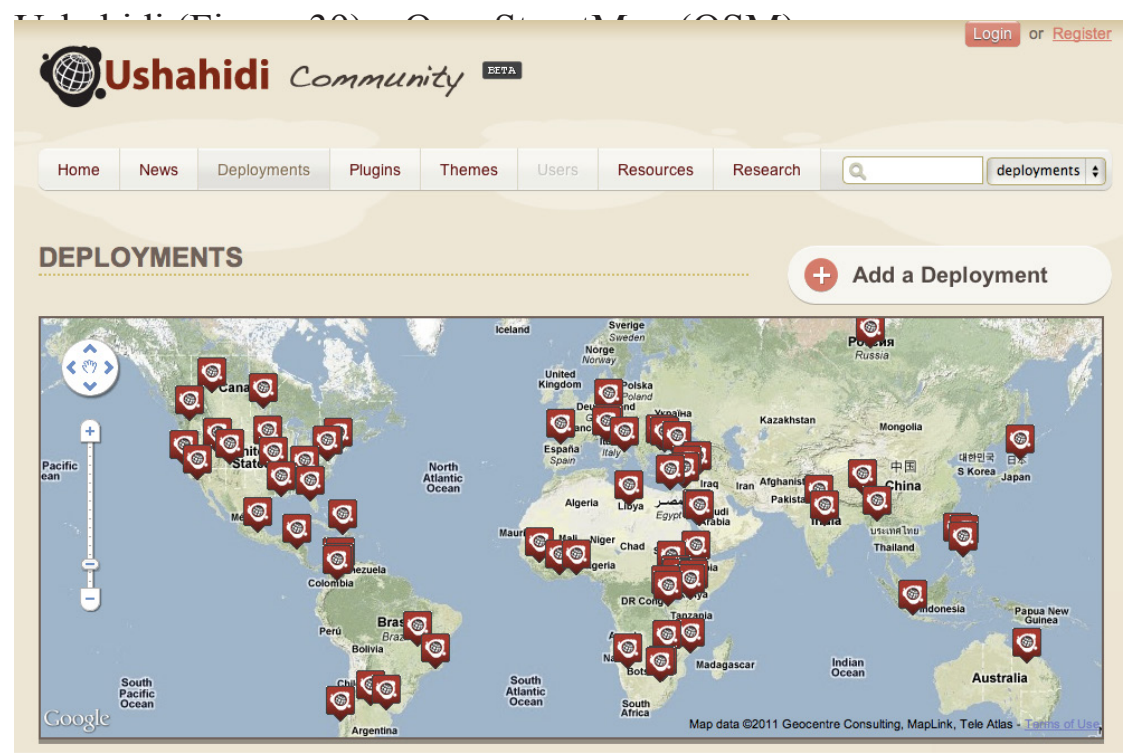

Figura 39- Interface de Ushahidi, desenvolve mapas colaborativos para grupos que querem denunciar ou evidenciar questões sócio-políticos Este mapa da imagem mostra onde Ushahidi já foi utilizado. Fonte:Ushahidi $\mathrm{B} \log$

Ushahidi foi uma das pioneiras nesse sentido, e teve seu início marcado por uma ação ativista específica. O nome significa "testemunho" no idioma Swahili (idioma do sudeste da África). O seu início foi em 2008, no Quênia, quando o país vivia um momento de grande incerteza política e violência, especialmente após as eleições que aconteceram ao final de 2007, que foram seguidas de muitos protestos e manifestações que acusavam o candidato Mwai Kibaki de haver manipulado a eleição.

Os protestos e manifestações rapidamente escalaram para uma vertente violenta; em questão de pouco tempo, o conflito havia se tornado um conflito étnico e o foco violento ficou principalmente voltado ao povo Kikuyu (a comunidade do candidato eleito). Segundo notícias do New York Times ${ }^{107}$ da época, o número de mortes já ultrapassava mil e a insegurança da 
população era intensa.

Foi nesse contexto de extrema tensão que o projeto Ushahidi surgiu com a finalidade de dar voz à população local e de trazer foco para a realidade vivida pela sociedade queniana. $\mathrm{Na}$ postagem do surgimento da Ushahidi, que ocorreu em um jornal eletrônico queniano, a empresa declarou uma das razões que impulsionaram o desenvolvimento da ferramenta:

“Acreditamos que o número de mortes que o governo, a polícia e a mídia relataram é notadamente subestimado. Nós também não pensamos que temos uma imagem verdadeira do que realmente está acontecendo relatórios de que todos nós ouvimos falar de familiares e amigos nas áreas afetadas sugerem que as coisas são muito piores do que o que ouvimos na mídia." 108 (USHAHIDI, 2008, s/n, tradução nossa)

Foi criado um mapa colaborativo em que qualquer um que tivesse acesso a um celular ou um computador pessoal poderia registrar, via e-mail ou mensagem de texto, relatos de violência política. Relatos esses que, além de se organizarem como eventos temporais, também se organizavam no sistema como eventos geograficamente localizados, garantindo assim leituras não só dos relatos mas também outro grau de leitura como, por exemplo, quais as localidades em que se concentravam o maior número de vítimas e quais as periodicidades em que a violência ocorria. Essa movimentação de informações trouxe à tona toda a fragilidade política vivida no momento, deu voz a testemunhas e vítimas das violências ocorridas.

A plataforma foi concebida com uma linguagem simples, dispensando expertise e técnica específica, o que garantiu uma aderência alta de usuários. Neste movimento, específicamente, o projeto contou com 45 mil usuários, número significativo e importante para que o movimento adquirisse expressividade suficiente. Para a organização, além dessas leituras imediatas possíveis, era importante o registro delas para que esse episódio não se perdesse na memória do povo.

108 "We believe that the number of deaths being reported by the government, police, and media is grossly underreported. We also don't think we have a true picture of what is really going on - reports that all have us have heard from family and friends in affected areas suggests that things are much worse than what we have heard in the media" (Ushahidi,2008) 
"Os quenianos demonstraram sua capacidade de amnésia seletiva uma e outra vez. Quando essa crise chegar ao fim, não queremos o que aconteceu, de ser varrido sob o tapete em nome de 'seguir em frente' - para que possamos avançar verdadeiramente, a verdade do que aconteceu precisa ser dita - Ushahidi (www .ushahidi.com) é a nossa pequena maneira de contribuir com isso." 109 (USHAHIDI, 2008, s/n, tradução nossa)

Esse caso, da violência política no Quénia, foi o que estabeleceu a organização Ushahidi. Desde então, muitos outros grupos espalhados pelo mundo contaram com o Ushahidi a fim de criar mapas colaborativos para enfrentar situações de seu próprio contexto sóciopolítico. Ushahidi encontrou nas mídias locativas uma maneira de acumular informações em um mapa colaborativo próprio para se contrapor a um acontecimento político local. A postura de enfrentamento diante do contexto surgiu da evidência de que dados e estatísticas eram manipulados para abrandar e manipular opiniões, além, claro, da crise de insegurança extrema vivida pela sociedade local.

O grupo encontrou, através de mapas colaborativos, uma maneira de expor sua denúncia com a colaboração de milhares de usuários e apresentar uma outra alternativa de expor dados atualizados em tempo real. Hoje Ushahidi se apresenta como uma empresa sem fins lucrativos que oferece a plataforma necessária para grupos ativistas e sociais que queiram fazer uso de mapas colaborativos para suas ações. A plataforma foi utilizada, por exemplo, após o terremoto do Haiti (2010) e o derrame de óleo no mar em Louisiana -EUA (2010), dentre outros (Figura 40).

Assim como o Ushahidi, o OpenStreetMap também é utilizado por várias diferentes iniciativas ativistas. O OpenStreetMap (OSM) é um projeto de mapeamento colaborativo de criação e atualização de um mapa livre e editável do mundo, com princípio de funcionamento por crowdsourcing. Os mapas são desenvolvidos por voluntários (VGI) que inserem dados de GPS portáteis, fotografias aéreas e de satélite. Os mapas são editados com softwares

109 Kenyans have demonstrated their capacity for selective amnesia time and time again. When this crisis comes to an end, we don't want what happened to be swept under the rug in the name of "moving forward" - for us to truly move forward, the truth of what happened needs to be told - Ushahidi ( www.ushahidi.com) is our small way of contributing to that." (Ushahidi,2008) 


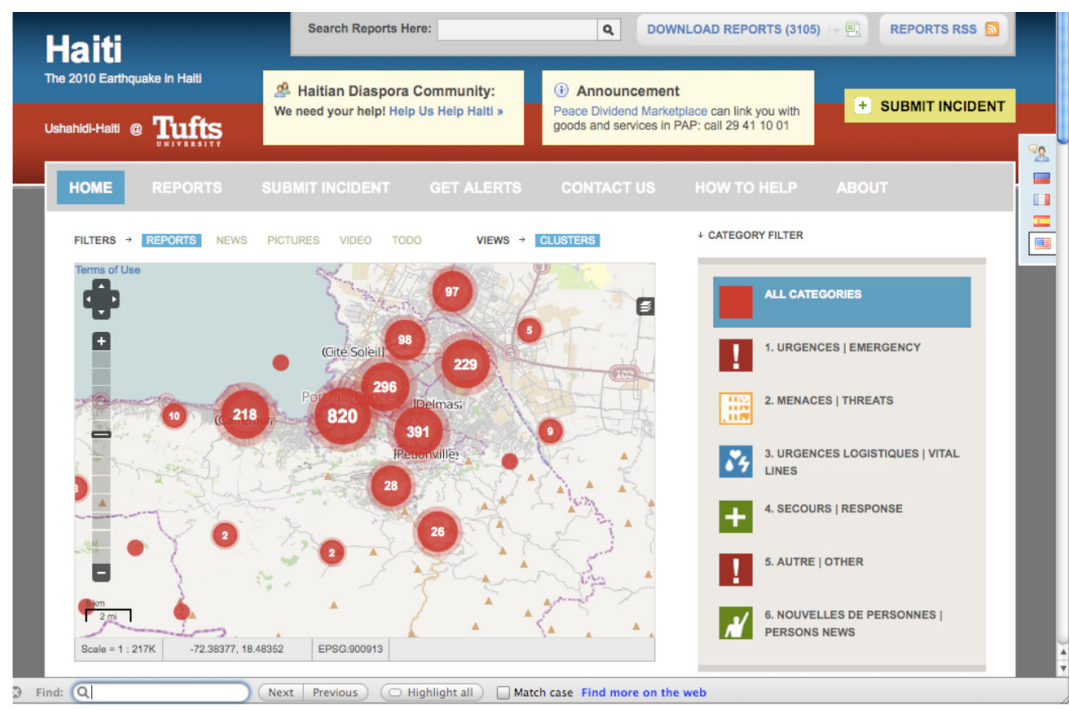

Figura 40- Interface do mapa colaborativos Ushahidi feito em 2010 para socorro após o grande terremoto que devastou o Haiti. Fonte: National Geographic

abertos por uma comunidade grande que confirma e revisa as informações, além de contar com a OpenStreetMap Foundation (OSMF) que formalmente opera os dados em nome da comunidade de mapeadores.

Os grupos ativistas têm criado seus mapas colaborativos através de mashups (modalidade de construção de mapas colaborativos já explicada no início deste capítulo) e para isso se utilizam de mapas-base como esses (Ushahidi/OpenStreetMap) ou Google Maps. Fazer uso de mapas-base garante um reconhecimento mais intuitivo e rápido, uma vez que são linguagens já muito difundidas. Além de linguagem e visual conhecido, são softwares livres, o que exime qualquer grande investimento financeiro e de tempo de repensar e programar uma plataforma cartográfica digital. Não considerar esse despendimento de tempo e dinheiro é, muitas vezes, resultante de um desinteresse em repensar este aspecto da cartografia, uma vez que o foco de muito desses grupos está em outras questões para o qual precisam do mapa, e claro, normalmente possuem uma realidade financeira limitada e já comprometida com mais uma série de investimentos de ligação mais direta com a causa de suas lutas.

Plataformas de uso intuitivo, e, em especial, softwares livres são características muito frequentes ou, em quase toda sua totalidade, desse tipo de contracartografia ativista. Utilizar plataformas com uma linguagem intuitiva facilita a colaboração e engajamento de usuários 
das mais diversas camadas sociais e econômicas, dispensando assim qualquer expertise ou treinamento. O uso de software livre, além de ser uma opção sem custo, abriga um aspecto político, por permitir livre acesso à programação e edição à necessidades específicas, e não ficar à mercê de parâmetros e programações predeterminados. Percebe-se que o foco e prioridade dessas contracartografias é expor e difundir a informação, e pouco se pensa sobre a representação em si dessas informações.

Após observar alguns mapas colaborativos utilizados por organizações e grupos ativistas, foi possível perceber que há dois tipos de perfis principais ativados por esses grupos. Uma é a de denúncia, que normalmente compila relatos de diversos usuários em torno de algum determinado tema, como foi, por exemplo, o primeiro caso do Ushahidi descrito no item anterior. O outro perfil é o de compartilhamento de recursos que normalmente não são evidenciados em mapas de distribuição comum (ex. serviços, locais de atendimentos, etc).
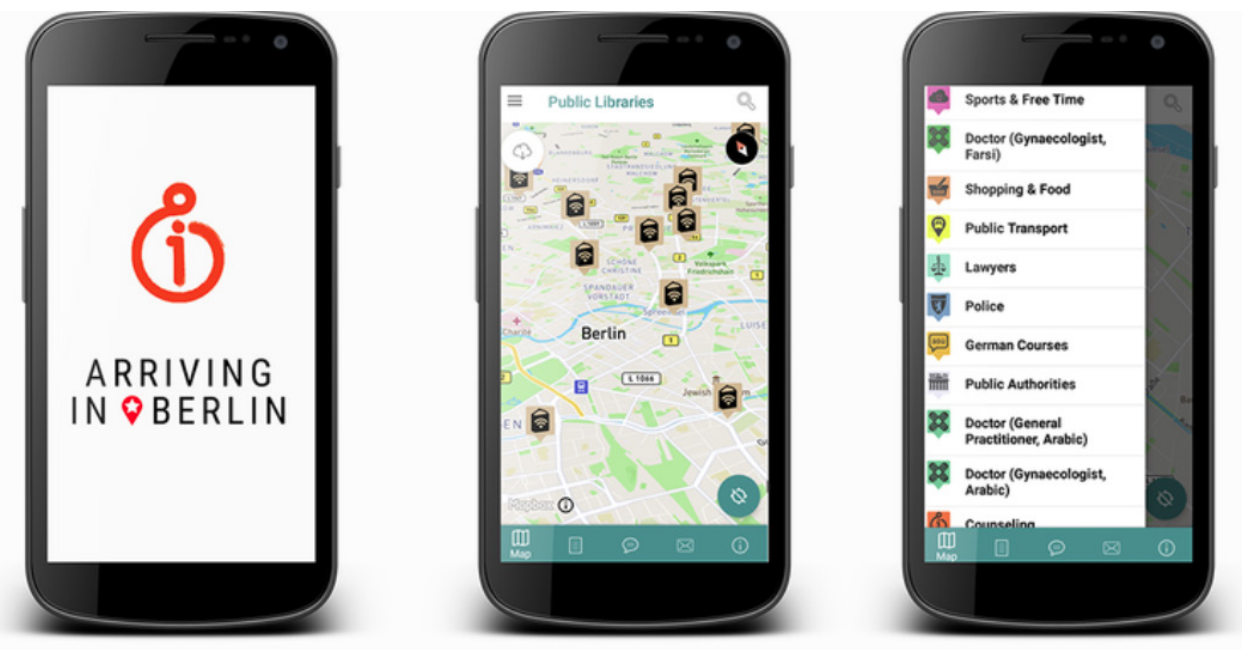

Figura 41- Interface do aplicativo Arriving in Berlin. Fonte: Arriving in Berlim

O Aplicativo Arriving in Berlin ${ }^{110}$ (Figura 41) é um exemplo de mapa colaborativo que tem esse perfil de compartilhar informações de recursos. Trata-se de um aplicativo desenvolvido por refugiados para refugiados, disponível inglês, árabe e farsi. A iniciativa partiu de refugiados

110 https://arriving-in-berlin.de 
que se estabeleceram na cidade de Berlim e disponibilizaram, através do aplicativo, as informações-chave para os refugiados recém-chegados na cidade. No aplicativo, é possível encontrar informações como advogados e clínicas com profissionais de saúde, que falam árabe ou farsi, obtêm informações sobre transporte público da cidade, agências de empregos, cursos de alemão gratuitos.

O 'Arriving in Berlin' surge em um contexto político de grande tensão, em que há um grande volume de sírios buscando refúgio no continente europeu. Momento que gerou uma série de reações diversas entre os países europeus, desde uma reação xenófoba até uma reação de acolhimento. A Alemanha, em especial Berlim, foi um dos locais europeus mais abertos e

\section{AStreetWatch}

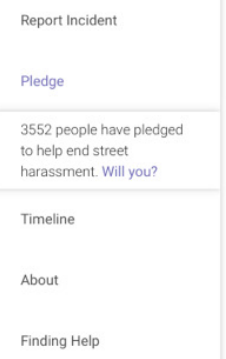

\section{Welcome to iStreetWatch}

We track racist and xenophobic harassment in public spaces.

If you have witnessed or experienced racist or xenophobic harassment, please report the incident to us.

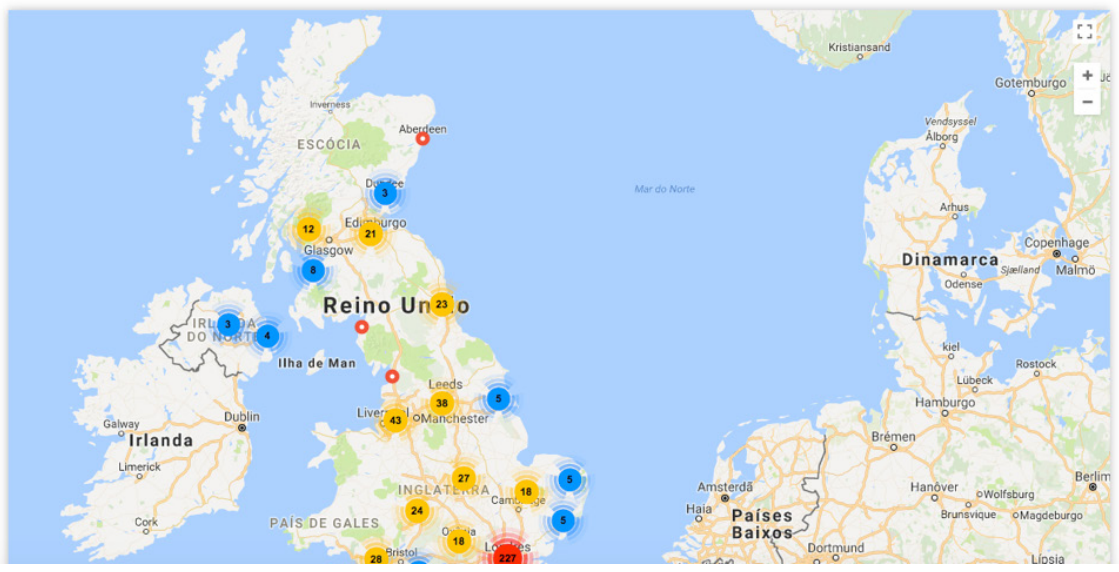

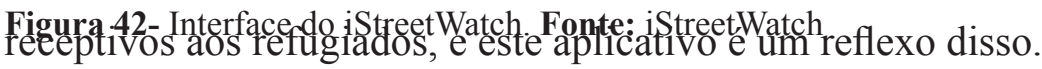

Logo após o Brexit, ainda contemporâneo ao contexto político econômico descrito acima, surgiu por exemplo, no Reino Unido uma onda xenófoba muito forte contra imigrantes recém-chegados e já estabelecidos. As ocorrências de violência foram tão marcantes que foi desenvolvido por um grupo de voluntários o iStreetWatch (Figura 42), que tem como objetivo engajar a minoria negra e imigrantes para denunciarem episódios de xenofobia e 
crime de ódio. Com essas denúncias, além de dar voz à minoria e poder estabelecer quais os locais mais seguros, pretende-se acompanhar a variação dessas taxas de violência conforme os discursos inflamados nacionalistas que passaram a ser pronunciados no país.

Os aplicativos 'iStreetWatch' e o 'Arriving in Berlin', apesar de surgirem em um mesmo contexto sociopolítico possuem aproximações às questões totalmente opostas. Um, de acolhimento; e outro, de alerta e perigo. Apesar dessas diferenças conceituais, possuem uma linguagem de representação muito similar; não há uma preocupação em rever a representação dos mapas ou em uma nova maneira de apresentar esses dados compilados.

Uma outra questão importante a ser notada, ao se tratar de mapas colaborativos de grupos e organizações de perfil ativista, é tentar entender quem realmente é o grupo que ativa essa rede colaborativa, pois isso nos diz muito sobre qual é realmente o público alvo das informações e como esses dados são articulados pelo grupo. Podemos citar aqui, por exemplo, dois aplicativos brasileiros com esse perfil, o 'Nós por Nós' e o 'Fogo Cruzado'.

Ambos aplicativos são de denúncia da violência e surgem em 2016 no âmbito de comunidades carentes do Rio de Janeiro. O 'Nós por Nós' (Figura 43) trata-se de um aplicativo desenvolvido pelo Fórum de Juventudes para moradores de favelas denunciarem violência policial através de texto, fotos, gravação de áudio e até mesmo vídeos. O grupo sentiu a necessidade da criação do mapa colaborativo após um mapeamento realizado no ano anterior (2015) em 15 favelas, com o qual perceberam uma constante alta de violência realizada por parte dos policiais. Resolveram adotar como instrumento não só para registro e dar voz às diversas vítimas, mas também educar os jovens sobre seus direitos e orientar como denunciar a instâncias maiores.

"a ferramenta não vai necessariamente resolver todos os problemas das favelas e as lutas que enfrenta a juventude negra. Mas é uma ferramenta que algumas organizações consideram um instrumento de luta" (GOULART ${ }^{111}$,

111 Fransérgio Goulart é o coordenador do projeto. Citação extraída de uma notícia on line divulgada no site Rio on Watch (http://rioonwatch.org.br/?p=19266) 


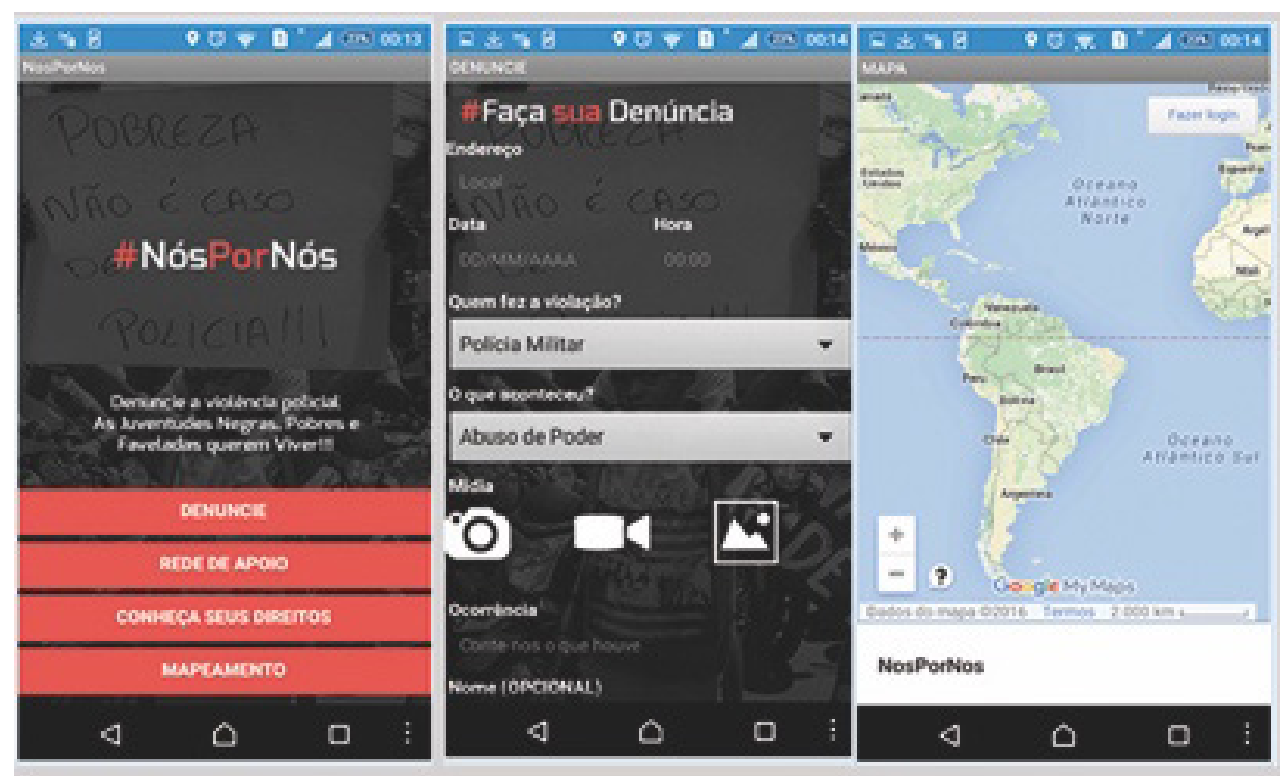

Figura 43- Interface do aplicativo Nós por Nós. Fonte: Nós por nós app.

$$
2016, \mathrm{~s} / \mathrm{n})
$$

O aplicativo Fogo Cruzado (Figura 44), por sua vez, trata-se de registro de tiroteios que acontecem nas comunidades do Rio de Janeiro e foi desenvolvido pela Anistia Internacional em junho de 2016. Um dos objetivos principais do aplicativo é dar visibilidade a tiroteios com que comunidades cariocas convivem diariamente. Atila Roque, diretor da Anistia Internacional no Brasil afirmou em uma entrevista concedida ao Anistia.org.br:

“Uma ferramenta como o app 'Fogo Cruzado' oferece um caminho seguro para expor a realidade a que as pessoas estão submetidas e a desproporcionalidade geográfica da violência no Rio. É mais uma maneira de pressionar as autoridades a adotarem políticas de segurança pública que respeitem os direitos humanos". (ROQUE, 2016, s/n)

A intenção é acumular dados para divulgá-los em mapas e análises abertos a consultas de autoridades, pesquisadores, imprensa e lideranças locais. Para Atila Roque, "com as informações adicionais solicitadas poderemos ter uma noção mais específica do custo social dessa violência para as pessoas e para a cidade". 


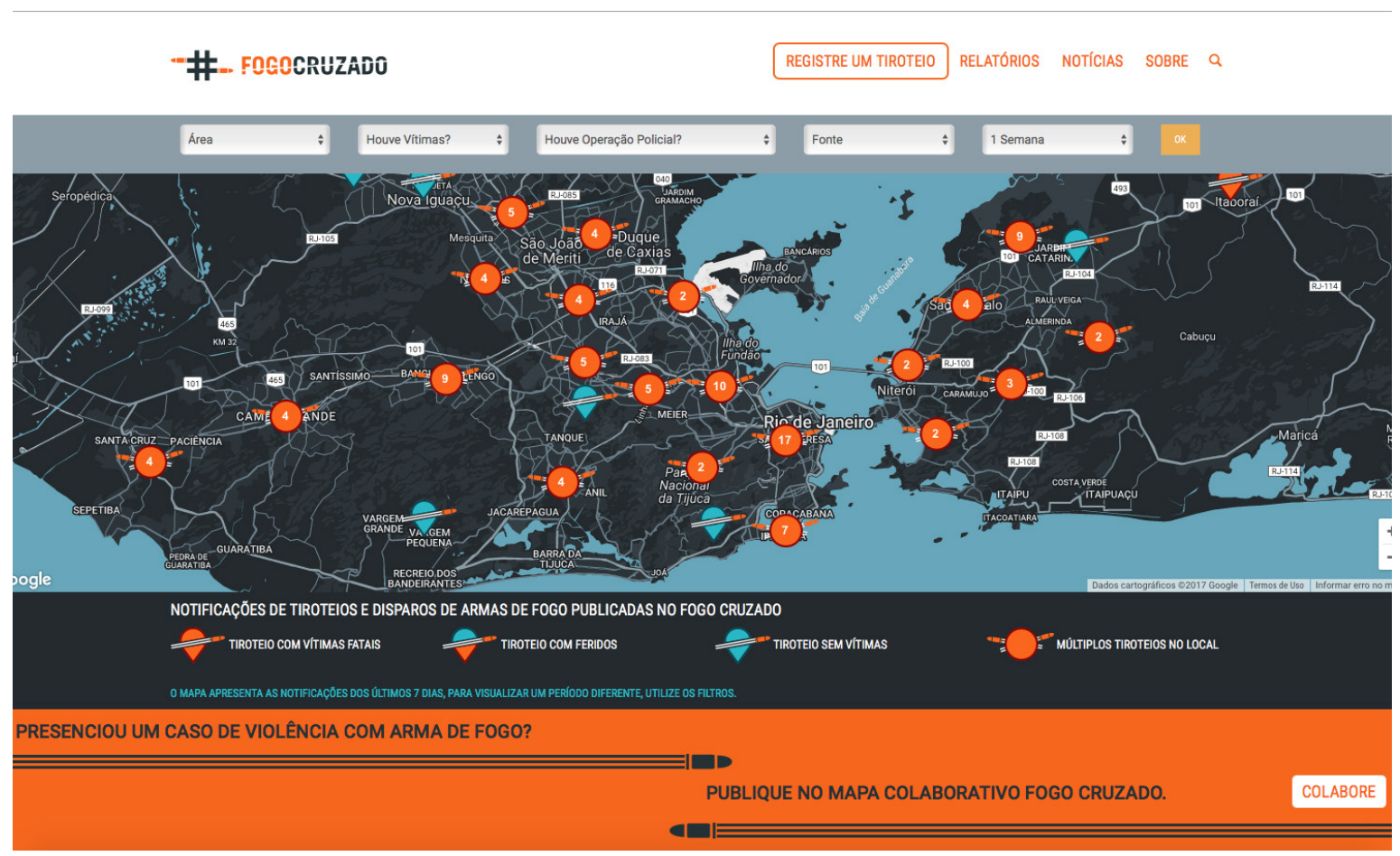

Figura 44- Interface do site 'Fogo Cruzado'. Fonte: Fogo Cruzado.

Apesar de ambos aplicativos surgirem em um contexto social similar, trazem, com a colaboração informacional dos usuários, formas completamente distintas de uso destes dados. Enquanto o primeiro, 'Nós por Nós', pretende com a denúncia acelerar discussões, trazer um caráter de enfrentamento e educação de direitos contra o abuso de poder das autoridades policiais, o 'Fogo Cruzado', por sua vez, alimenta um banco de dados aberto com as informações recolhidas e apresenta, de maneira menos velada, os números e índices sobre os tiroteios que acontecem nas favelas, para haver maior evidência da realidade que essas comunidades têm enfrentado e, com os dados e índices recolhidos, pressionar autoridades locais.

São muitos os mapas colaborativos hoje, e dos mais diferentes temas e diferentes iniciativas. 
Podemos citar alguns exemplos, como o 'hollaback'112 (Figura 45) e o 'Chega de Fiu Fiu'113(Figura 46), ambos voltados para mulheres denunciarem assédios. Ou, então, 'Onde fui roubado' (Figura 47) e 'WikiCrimes' (Figura 48), ambos para que vítimas possam denunciar roubos ou violências sofridas na cidade. Se uma lista de milhares de mapas colaborativos que tenham caráter de denúncia pode ser citada, a questão que fica é se realmente essas ações e esses dados acumulados, que traduzem visualmente estatísticas, se convertem em ações eficazes para os problemas levantados. Quanto os usuários/vítimas que denunciam nesses mapas colaborativos têm realmente de qualquer retorno e quanto os grupos que ativam essas ferramentas conseguem utilizar esses dados de maneira criativa e eficaz? Essas iniciativas têm como objetivo trazer dados à visibilidade, para com isso questionar, denunciar e fornecer informações normalmente não disponibilizadas. Nesse cenário, uma dupla questão aparece: por um lado, em uma realidade com saturação de mapas como a de hoje, há um desafio de se manter relevante; e, por outro, ao que parece, conforme os mapas adquirem maiores funções sociais, políticas, econômicas e militares, dentre outras, maior sua profusão e circulação.

A ordenação dessas informações georreferenciadas, o modo de apresentá-las e a associação delas a uma projeção cartográfica configura uma forma de visualização informacional predominante da atualidade. Pequenos ícones associados a coordenadas geográficas se tornam índice de alguma informação, que, por sua vez, leva a algum link portador de maiores informações associadas, os quais também são links para tantas sucessivamente.

Ainda no que diz respeito à profusão de mapas digitais e colaborativos, percebe-se que a grande maioria dos colaborativos lançados por iniciativas ativistas possui normalmente um pico de engajamento por parte dos usuários, sucedido por uma queda expressiva, sendo gradativamente abandonados em meio à grande web. Vale entender que, para que esses mapas realmente cumpram seu papel, não basta a iniciativa de disponibilizá-los, pois o papel dos usuários colaboradores é igualmente fundamental. A eficácia dessas denúncias está diretamente ligada ao nível de engajamento que a iniciativa consegue captar e manter. A responsabilidade não fica apenas nas mãos de quem propõe o mapa, mas também na de

112 https://www.ihollaback.org

113 http://chegadefiufiu.com.br 


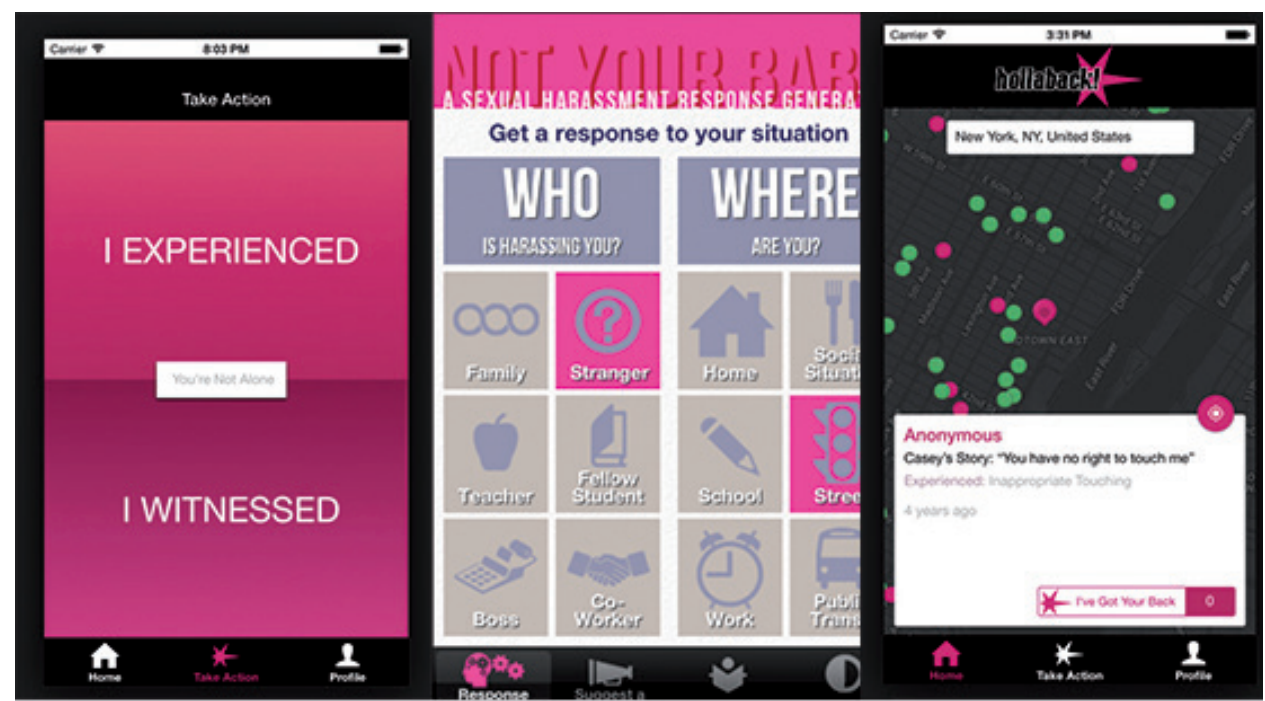

Figura 45- Interface do aplicativo 'iHollaBack'(fundado em 2005). Iniciativa ativista de mulheres e LGBTs que sofreram assédios e violências que tinham suas denúncias ignoradas por autoridades locais em Nova Iorque. Descontentes com o descaso das autoridades locais, resolveram criar o aplicativo para dar visibilidade ao problema. A plataforma foi bem-sucedida em termos de engajamento; em 2010 recebeu investimento de legisladores de Nova Iorque e, em 2012, ela se multiplicou para diversas outras cidades.

Fonte: iHollaBack app

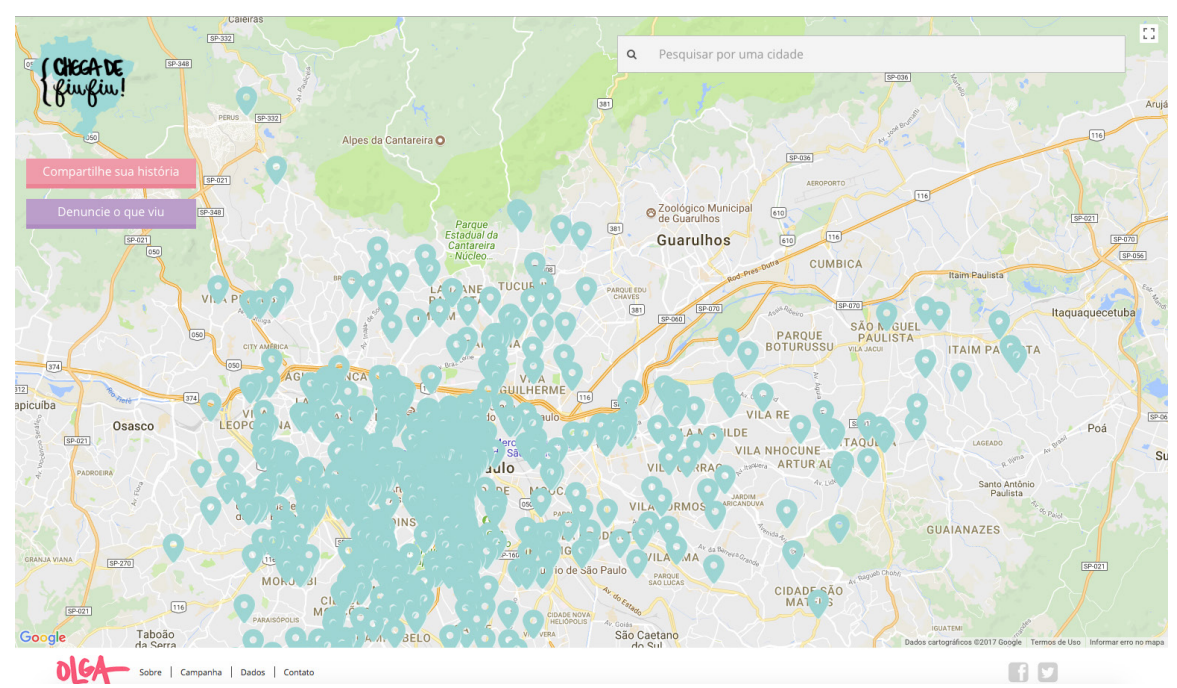

Figura 46- Interface do aplicativo 'Chega de FiuFiu' (fundado em 2013). Iniciativa de uma jornalista que, investigando o problema de assédio às mulheres, desenvolveu a campanha e a organização sem fins lucrativos para trazer luz ao problema. Em 2014, organizou um financiamento coletivo para dar seguimento à futuras ações da campanha. Fonte:Chega de Fiu Fiu 

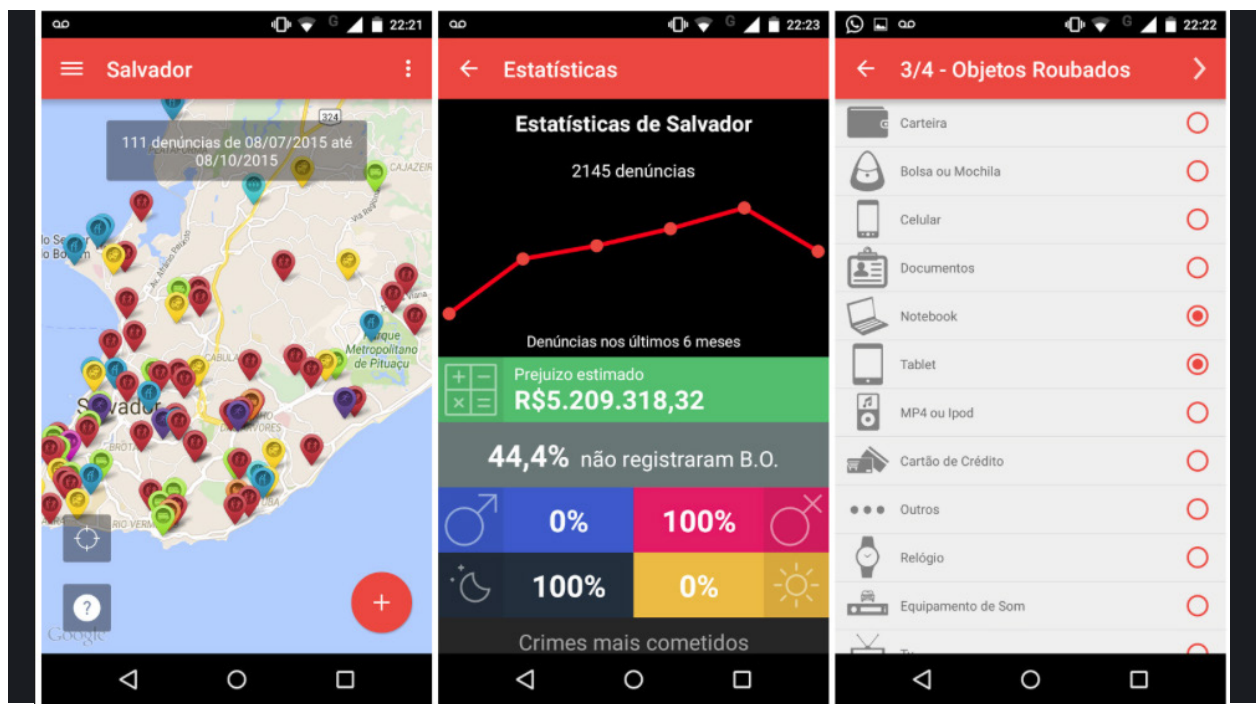

Figura 47- Interface do aplicativo 'Onde Fui Roubado'(lançado em 2012). Diante aos frequentes problemas de segurança pública enfrentada pela população brasileira, criou- se o aplicativo. Para que, além de gerar um mapa em que seja possível consultar e se informar de quais regiões são mais seguras ou perigosas, também há a intenção de acúmulo de dados estatísticos para que a população utilize a fim de cobrar atitudes cabíveis para autoridades e representantes políticos locais. Fonte:Onde Fui Roubado app.

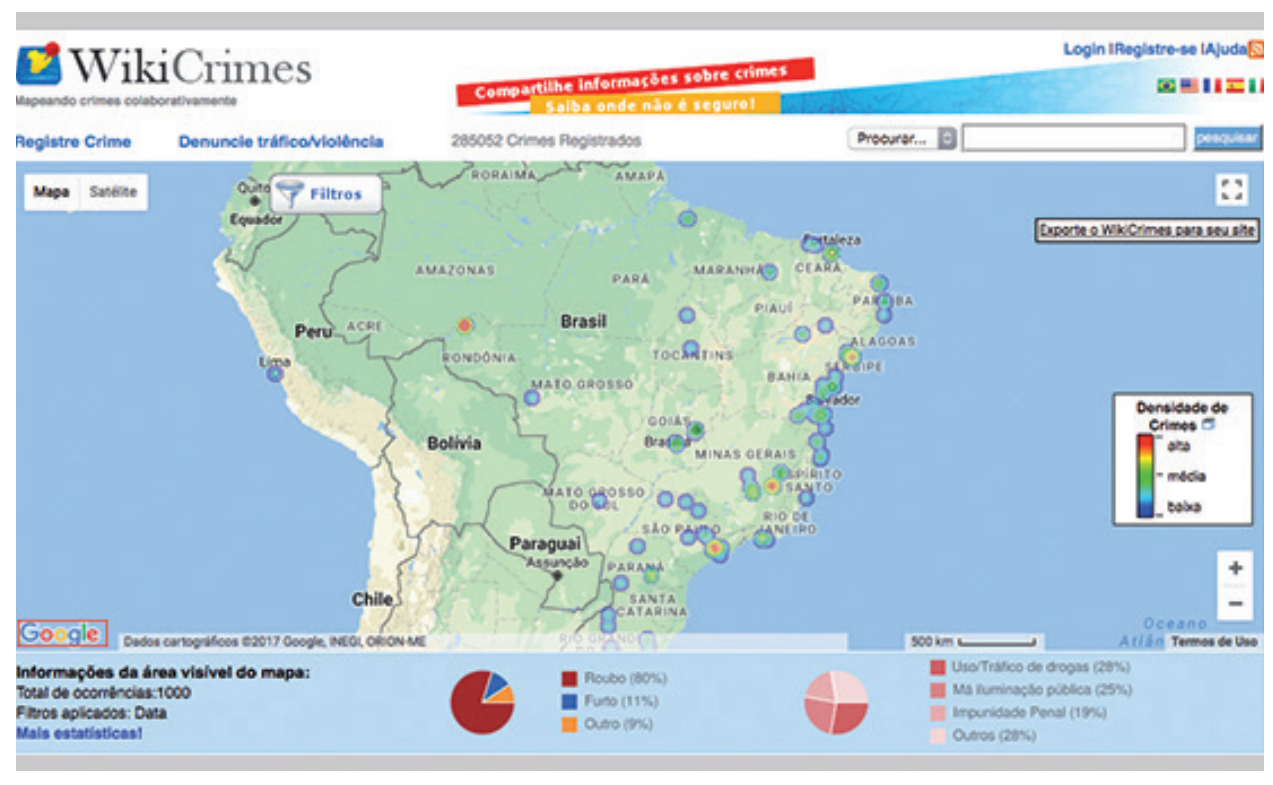

Figura 48- Interface de Wikicrimes, um mapa colaborativo que tem como objetivo denunciar atos de violência (lançado em 2007). Criado por especialistas em segurança pública, que pretendem, além de mapear e identificar áreas seguras ou violentas pelo mundo, também trazer a transparência de registros de crimes e quebrar a lógica de monopólio das informações pelo Estado. Fonte:Wikicrimes 
iniciativas posteriores que trabalhem para manter toda a engrenagem de colaboração, deem utilidade e gerem novas proposições a partir dos dados e índices captados.

São poucos os mapas colaborativos de "denúncia", especialmente os que conseguem manter um engajamento constante do público. Existem várias possibilidades de isso acontecer, uma é que estes grupos ativistas não têm como prática, e talvez isso se dê inclusive por razões financeiras, investir em divulgação de suas ferramentas de maneira constante. Outra possibilidade talvez seja que dados e denúncias levantados em aplicativos como esses não costumam trazer resultados contundentes e a curto prazo ao olhar do público em geral.

Com a facilidade de acesso à rede e a de conexão, os mapas colaborativos se tornaram uma ferramenta eficiente e de amplo alcance para os grupos ativistas. No entanto, ao que se observa, assim como qualquer conteúdo criado na web, é necessário um esforço e estratégia para se manter relevante em um mundo virtual tão efêmero e saturado.

A preocupação desses contracartógrafos está longe de questionar a plataforma em si, de repensar os limites e o que esta fórmula amplamente difundida possui. Não há uma preocupação clara de se aprofundar nas nuances informativas que um mapa possui, como o geógrafo Harley havia apresentado em seu artigo 'Desconstructing Maps' ${ }^{114}$. Cabe aqui destacar que, no mesmo período em que os mapas colaborativos têm permeado o cotidiano aqui descrito neste capítulo, tanto para uso diário quanto para ações ativistas, as revisões da disciplina cartografia se processam.

Percebe-se, portanto, que ainda que esses grupos ativistas se utilizem da cartografia para desafiar e desvelar imposições de poder, estas contracartografias ainda não se aprofundam nas questões levantadas por teóricos da cartografia ou, ainda, por artistas que têm se debruçado sobre o assunto (foco do capítulo seguinte). A contracartografia desses grupos ativistas se ocupa de maneira mais direta em trazer temas para debate, por meio de denúncias e disseminação de recursos, através do processo de disponibilização e visibilização de dados e informações. Encontraram nesta ferramenta colaborativa uma maneira de ampliar o alcance de suas vozes e engajar um público específico desejado. A ação política que se propõem ao 114 (HARLEY,1989) 


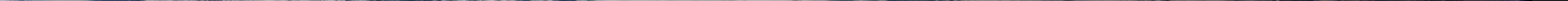




\section{Capítulo 3}

\section{Práticas contracartográficas na arte}


utilizar a contracartografia parece se dirigir ao recolhimento e desvelamento de informações e índices/dados estatísticos que embasem reinvindicações.

Em meio ao debate existente no campo da geografia (como vimos no item 1.3), há uma busca reflexiva de desconstruir os mapas e suas representações espaciais, procurando estudar as maneiras pelas quais eles são produzidos e usados por diferentes indivíduos e grupos. De tal discussão entre os geógrafos teóricos, percebe-se que não existe um 'caminho certo' para produzir mapas, mas fica evidente que seus criadores precisam ser sensíveis à política e ao contexto de sua criação e uso. Denis Wood, um dos principais geógrafos que propõem o contramapeamento* como saída para escapar do poder dos mapas e apontam a arte como a esperança de propor um novo caminho à cartografia, afirma:

"Os artistas do mapa estão apagando a linha que os cartógrafos tentaram desenhar entre sua forma de comunicação gráfica (mapas) e outros (desenhos, pinturas e assim por diante). Desta forma, os artistas cartógrafos estão recuperando o mapa como uma função de discurso para as pessoas em geral"115 (WOOD, 2006, p. 5, tradução nossa)

Tal potencial gerador de novas cartografias, já apontado como de extremo interesse por Wood em texto de 2006, é reafirmado por ele e Krygier em outro texto de 2009:

"Os artistas do mapa reivindicam o poder do mapa para alcançar outros fins além da reprodução social do status quo. Os artistas do mapa não rejeitam mapas. Eles rejeitam a autoridade reivindicada pela cartografia profissional exclusivamente para retratar a realidade como é. Em lugar de valores profissionais como valores de precisão, os mapas da arte afirmam valores de imaginação, justiça social, sonhos e mitos; [...] Os artistas

$115[\ldots]$ map artists are erasing the line cartographers have tried to draw between their form of graphic communication (maps) and others (drawings, paintings, and so on). In this way map artists are reclaiming the map as a discourse function for people in general." (Wood, 2006, p. 5) 
insistem que seus mapas traçam mundos sociais e culturais tão 'reais' quanto os mapeados por cartógrafos profissionais." 116 (WOOD; KRYGIER, 2009, p. 9, tradução nossa)

De maneira distinta dos mapas colaborativos ativistas, quando artistas passam a incorporar mídias locativas para suas práticas contracartográficas abrem-se outras maneiras de pensar e representar cartografias. Surgem outros modos de relacionar mapeamentos e espaços físicos e dinâmicas sociais. Passam a ser exploradas várias dinâmicas possibilitadas pelas mídias, desde a estrutura de representação do mundo a partir das noções de percurso, até a dinâmica imposta pelos poderes vigentes. Os pesquisadores de Comunicação e estudos de Mídias, Paraskevopoulou, Charitos e Rizoupoulos, consideram significativo, que na maioria das vezes, os artistas possuem como motivação:

“a perspectiva de sensibilizar o público sobre várias questões, como o processo de criação de mapas, localização e posicionamento preciso, a capacidade de formar redes sociais na rede urbana, a vigilância, o rastreamento de corpos ou objetos humanos ou como todas essas questões afetam as escolhas dos povos e vida cotidiana"117 (PARASKEVOPOULOU; CHARITOS; RIZOUPOULOS, 2008, p. 2, tradução nossa)

\subsection{DAS DEAMBULAÇÕES AOS PERCURSOS GEORREFERENCIADOS}

As discussões no universo de práticas que se vinculam às noções de percurso e localidade não são inéditas no campo da arte. Elas vêm se desenvolvendo desde a década de 1920 até os dias atuais. No movimento Dadá, as práticas se pautavam por operações estéticas conscientes,

\footnotetext{
116 " [...] Map artists are claiming the power of the map to achieve ends other than the social reproduction of the status quo. Map artists do not reject maps. They reject the authority claimed by professional cartography uniquely to portray reality as it is. In place of such professional values as accuracy and precision, art maps assert values of imagination, social justice, dreams, and myths; [...] Artists insist that their maps chart social and cultural worlds every bit as 'real' as those mapped by professional cartographers." (WOOD; KRYGIER, 2009, p. 9)

117 " the prospect of raising public awareness on various issues such as process of map-making, location and precise positioning, the ability to form social networks in the urban grid, survaillance, the tracking of human bodies or objects or how all these issues affect peoples choices and everyday life.” (PARASKEVOPOULOU; CHARITOS; RIZOUPOULOS, 2008, p. 2)
} 
"A operação do dadá ofereceu aos artistas uma nova possibilidade de agir sobre a cidade" (CARERI, 2013, p. 75). Em 1921, o movimento realiza na cidade de Paris uma série de “visitas-excursões' a lugares banais da cidade, negando locais valorizados e famosos. O Dadá repensa a possibilidade de agir na cidade, encara o caminhar como uma forma estética e como uma maneira de enfrentar o sistema da arte. A partir dessas experiências, em 1924, definem a Deambulação ${ }^{118}$ e acontece a passagem do Dadá para o Surrealismo. O palco de ação deixa de ser a cidade e passa a ser o território 'vazio', nas palavras de Careri:

"O percurso surrealista coloca-se fora do tempo, atravessa a infância do mundo e toma as formas arquetípicas da errância nos territórios empáticos do universo primitivo. O espaço apresenta-se como um sujeito ativo e pulsante, um produtor autônomo de afetos e de relações.” (CAREI, 2013, p. 78)

Nos anos 50, surgem os Situacionistas, que contestam a deambulação surrealista e cunham um novo termo: a dérive. Mais precisamente, neste momento Guy Debord ${ }^{119}$ traz um conceito conhecido como Psicogeografia ${ }^{120}$ (ciência da deriva), que praticamente foi o conceito central do movimento. Para esse grupo o perder-se é uma expressão da antiarte, utilizando-se disso como uma subversão do sistema da época. Entendem a deriva como uma construção e experimentação de novos comportamentos, pretendendo superar o conceito de deambulação dos surrealistas. "Com os situacionistas, a cidade inconsciente e onírica dos surrealistas é substituída por uma cidade lúdica e espontânea.” (CARERI, 2013, p. 97)

Essa espontaneidade, a deriva, proposta pelos Situacionistas se torna um método de subversão, propõe-se remapear o mundo, identificar outros fluxos e forças na experiência

118 “A deambulação - termo que traz consigo a própria essência da desorientação e do abandono no inconsciente - desenvolve-se entre bosques, campos, sedeiros e pequenos aglomerados rurais.” (CARERI;2013:78)

119 Guy Débord: Foi um escritor francês e um dos principais pensadores do movimento Situacionista.

120 Psicogeografia - a ciência da deriva - introduzida pela primeira vez no discurso Situacionista por Guy Debord no artigo "Introduction to a Critique of Urban Cartography" (1955). 
de uma cidade. Para Debord, a psicogeografia era tão real e precisa quanto os mapas que caracterizam as cidades e as forças geopolíticas tradicionais.

No entanto, é ao final da década de 60 que artistas ampliam seu campo de ação. Passam a apresentar uma forma artística, denominada Land Art, uma arte que se propõe a explorar "lugares". O objeto escultórico passa a ser entendido como uma construção do território e, como consequência, vão sendo construídas novas apreensões da paisagem. A prática da Land Art marcou um momento de consciência artística em que obras de arte passam a ser executadas fora das galerias e dos museus a fim de reconquistar a experiência do espaço vivido e as grandes dimensões de paisagem.

É no contexto da Land Art, por exemplo, que o artista Richard Long atua. O artista discute desde a experiência do percurso ao entendimento de um percurso estético. Uma das obras que se destaca é: A Line Made by Walking (1967). A obra (Figura 49) foi considerada uma passagem importante da arte contemporânea devido à sua radicalidade e simplicidade formal. Nessa obra, o artista realiza uma combinação entre a linha (a escultura) e a ação (o caminhar).

A imagem da faixa da grama pisoteada contém em si a presença da ausência. Fica então o rastro de uma ação, de um corpo. $\mathrm{O}$ corpo se faz perceber não como objeto representado na imagem, mas como um índice, ponto de vista, como algo presencial. O rastro deixado pelo corpo, agindo na paisagem, transforma-o em experiência perceptiva, demarcando uma interação do artista no mundo. O registro desta escultura existe somente como fotografias que são subsequentemente exibidas em galerias ou reproduzidas em publicações especializadas. Esses registros possuem um significado além de um simples documento que chancela a obra feita, mas registra o percurso, demonstra o deslocamento do artista.

Práticas como essas no campo artístico passaram a ampliar suas atuações incorporando outros aspectos da realidade (ex. discussões políticas, econômicas, etc.). Já na década de 90, podemos citar o artista Francis Alÿs, que desenvolveu diversos trabalhos usando o percurso caminhado como produção de espaço. Alÿs desenvolveu uma série de trabalhos 


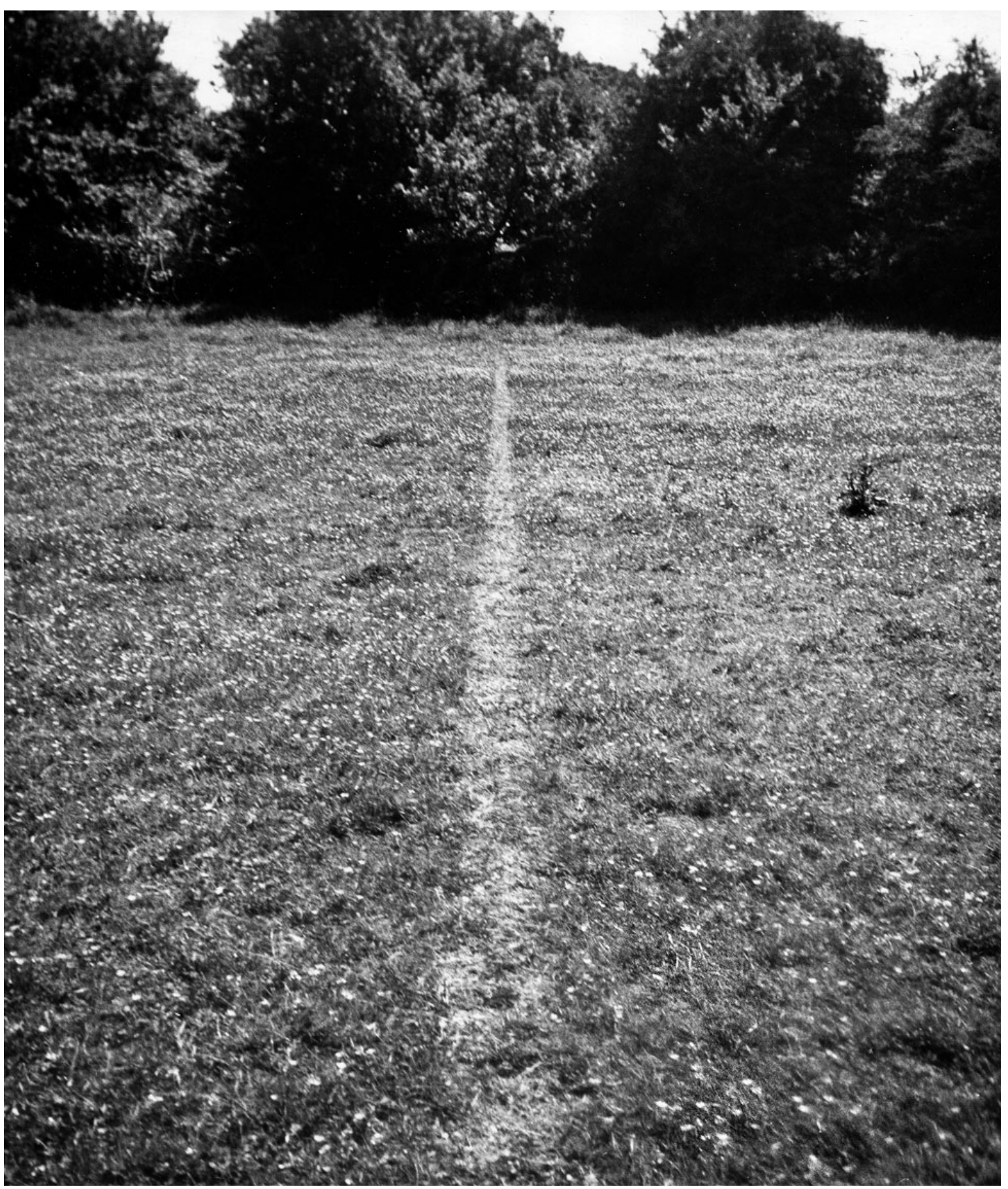

Figura 49- A Line Made by Walking (1967) Richard Long - Uma linha reta "esculpida" sobre o terreno simplesmente pisoteando a grama. Esta ação resulta em um sinal que ficará impresso apenas na foto e desaparecerá com o tempo quando a grama crescer. Fonte: richardlong.org 
pelo mundo; dentre os vários exemplos possíveis, podemos citar a obra realizada em Israel (2004) chamada: The Green Line: Sometimes doing Something Poetic Can Become Political, and Sometimes Doing Something Political Can Become Poetic. Neste trabalho (Figura 50), o artista utilizou tinta verde para demarcar seu percurso ao longo do limite armistício, limite este que havia sido demarcado por Moshe Dayan com um lápis verde em um mapa no ano de 1948. Uma das questões que motivaram o artista foi: esse limite funciona como uma divisão social e espiritual na cidade de Jerusalém?

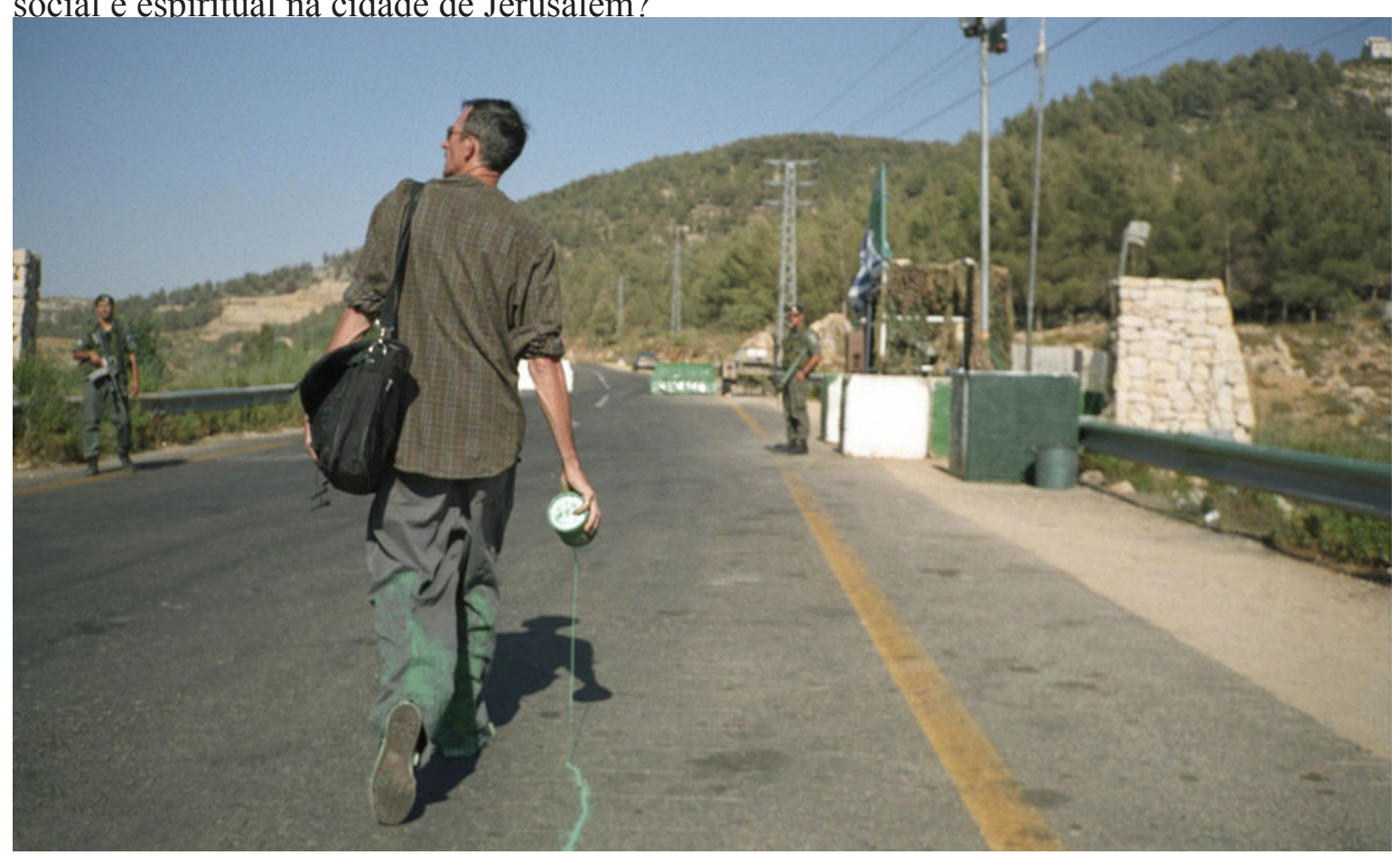

Figura 50- The Green Line: Sometimes doing Poetic Can Become Political, and Sometimes Doing Something Political Can Become Poetic (2004) - Francis Alÿs. Fonte: theredlist.com

"Pode uma intervenção artística, verdadeiramente, trazer uma maneira imprevista de pensar, ou é mais uma questão de criar um sentimento de 'falta de sentido' que mostra o absurdo da situação? Pode uma intervenção artística traduzir tensões sociais em narrativas que por sua vez, intervêm na paisagem imaginária de um lugar? Pode um ato absurdo provocar uma transgressão que faz você abandonar os pressupostos do senso 
comum sobre as fontes de conflito? Pode esses tipos de atos artísticos trazer possibilidades de mudança? Em todo caso, como a arte permanece politicamente significativa sem assumir um ponto de vista doutrinal ou aspirante a se tornar ativismo social?” (ALŸS, 2007, p. 1, tradução nossa $)^{121}$

O foco deste trabalho não está exatamente em trabalhos artísticos como os citados acima, pois o recorte da pesquisa inclui o uso de mídias locativas e dados geolocativos. Mas a intenção com essa breve apresentação é demonstrar que vinculações entre a arte e o pensar cartográfico vêm progressivamente se desenvolvendo. $O$ recorte deste trabalho é uma parte de um amplo espectro de atuação da arte na cartografia. O que começou como uma linguagem estética de deambulação passa, aos poucos, a discutir percursos e os registrar até aliar essas linguagens a discussões sociais e políticas. Reflexões sobre as ações artísticas com a cartografia passam a permear as discussões na geografia e, como bem afirma o geógrafo Denis Wood: “Os mapas de arte estão sempre apontando para mundos diferentes dos mapeados por instituições normativas"122 (2006, p. 10)

Em meio a esse desenvolvimento das atuações dos artistas-cartógrafos que focam as várias dimensões das representações de percursos e localizações espaciais, a tecnologia das mídias locativas vem para somar nesse campo. Segundo Marc Tuters e Kazys Varnelis, no artigo 'Beyond Locative Media'123, foi com a chegada das mídias locativas que ocorreu uma transição importante para as artes visuais (ou mídia arte), pois permitiu uma reinvindicação de um "[...] mundo além das galerias ou monitores de computadores como seu território" $(2005 \text {, p. 1, tradução nossa })^{124}$

\footnotetext{
121 "Can an artistic intervention truly bring about an unforeseen way of thinking, or it is more a matter of creating a sensation of 'meaninglessness' that shows the absurdity of the situation? Can an artistic intervention translate social tensions into narratives that in turn intervene in the imaginary landscape of a place? Can an absurd act provoque a transgression that makes you abandon the standard assumptions on the sources of conflict? Can those kinds of artistic acts bring about the possibility of change? In any case, how can art remain politically significant without assuming a doctrinal standpoint or aspiring to become social activism?” (ALŸS,2007, p.1)
}

122 “Art maps are Always pointing toward worlds other than those mapped by normative mapping institutions.” (WOOD, 2006, p.10)

123 (TUTERS;VARNELIS, 2006)

124 “[...] the world beyond either gallery or computer screen as its territory." (TUTERS; VARNELIS, 2006, p. 1) 
Vale citar aqui o artista Ben Russel, que em 1999, fez uma reflexão sobre a mídia locativa a ser considerada nas obras que serão aprofundadas neste trabalho.

"Mídia locativa é um termo que une uma série de questões, perspectivas críticas e práticas. Sua premissa catalítica era uma consciência e engajamento civil com um 'constructo operacional' de origem militar. Uma combinação de GPS, comunicações de dados móveis e computação móvel permitiria a anotação do espaço. Essa premissa catalítica não é mídia locativa, não é o objetivo ou o ponto. Mídia locativa é muita coisa: Um novo local para velhas discussões sobre relacionamento ou consciência do lugar e outras pessoas. Uma estrutura interna que ativamente engaja com crítica e formatos um rápido conjunto de desenvolvimentos tecnológicos. Um contexto que explora novos e velhos modelos de comunicação, comunidade e trocas. Um nome para o formato ambíguo da rápida implementação de vigilância e controle de infraestrutura." (RUSSELL, 2007, p. 1, tradução nossa) ${ }^{125}$

Diante das diversas questões disparadas pelas práticas cartográficas, para alguns artistas, utilizar tecnologias locativas foi um passo natural. Além de possibilitar uma linguagem relativamente difundida, também levanta aspectos pertinentes à contemporaneidade. Tuters e Varnelis (2006) categorizam duas modalidades de trabalhos com mídias locativas: anotativos (virtualmente marcando o mundo) e fenomenológicos (traçando a ação do sujeito no mundo). A primeira modalidade, os anotativos, segundo os autores são "projetos que geralmente buscam mudar o mundo adicionando dados nele" (2011, p. 3, tradução nossa) ${ }^{126}$.

125 "Locative media is a term that ties together a set of questions, critical perspectives and practices. Its catalytic premise was civilian awareness and engagement with a particular 'operational construct' with military origins. A combination of GPS, mobile data communications and mobile computing would allow the annotation of space. This catalytic premise is not locative media; it is not the goal or the point. Locative media is many things: A new site for old discussions about the relationship of consciousness to place and other people. A framework within which to actively engage with, critique, and shape a rapid set of technological developments. A context within which to explore new and old models of communication, community and exchange. A name for the ambiguous shape of a rapidly deploying surveillance and control infrastructure." (RUSSELL;2007:1)

126 'Annotative projects generally seek to change the world by adding data to it[...]' (TUTERS;VARNELIS, 2011, p. 3) 
Enquanto os fenomenológicos são "projetos baseados em traçados [que] tipicamente buscam usar alta tecnologia para estimular práticas cotidianas quase extintas como andar ou ocupar espaços públicos" (2011, p. 4, tradução nossa) $)^{127}$.

Assim como Long, foram vários os artistas que surgiram e que se propuseram a trabalhar sua localidade enquanto se moviam pelo mundo. No entanto, hoje, o uso do GPS se tornou uma ferramenta de interesse para muitos artistas que lidam com a temática de percurso e cartografias. O GPS se tornou um meio de desenho, artistas se utilizam do próprio corpo ou de terceiros para demarcar percursos. Uma obra que podemos citar aqui é Amsterdam Real Time (2002) de Esther Polak, Jeoren Kee e Waag Society (Figura 51). Foi uma obra que teve apoio financiador do governo holandês e de uma rede de telecomunicação. A obra era uma grande projeção de um mapa da cidade de Amsterdam que mostrava linhas coloridas que eram desenhadas em um fundo preto. Cada linha colorida correspondia a diferentes pessoas vivendo suas vidas rotineiras na cidade.

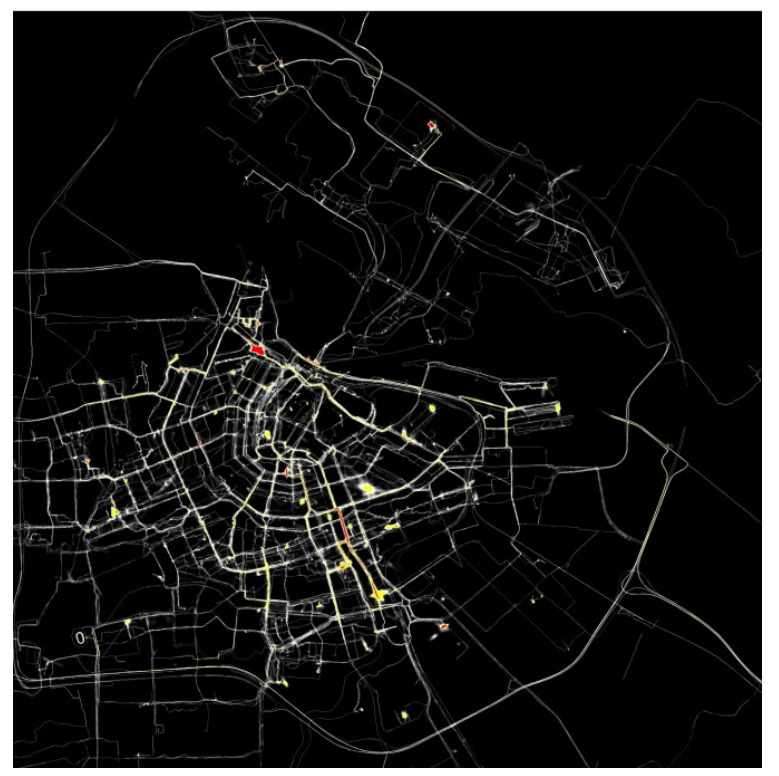

Figura 51-Amsterdam Real Time (2002) de Esther Polak, Jeoren Kee e Waag Society.

No entanto, Brian Holmes, quando menciona esta obra em seu texto 'Drifting Through the Grid: Psychogeography and Imperial Infraestructure', aponta fragilidades presentes na public space." (TUTERS;VARNELIS, 2006, p. 4) 
obra:

"[...] a linha de vida individual oscilante aparece ao mesmo tempo como testemunho da singularidade humana no tempo e prova do desempenho infalível do sistema de mapeamento de satélites. Muitas vezes, na sociedade contemporânea, a estética é política como decoração." 128 (HOLMES, 2003, $\mathrm{s} / \mathrm{n}$, tradução nossa)

Para Holmes a estética da deriva está por toda parte; no entanto, estamos totalmente imersos em uma "grid de uma infraestrutura imperialista", ou seja, é necessário que os trabalhos artísticos cartográficos assumam este tema criticamente. Tuters e Varnelis (2006) apontam, no artigo, como tais obras como Amsterdam Real Time (2002), que receberam financiamento de grandes corporadoras de comunicação, inclusive governamental foram severamente criticadas na esfera artística. As críticas variavam desde o fato de que obras que fazem uso de mídias locativas deveriam trazer uma consciência crítica e amadurecida sobre o limite de apropriação possível da tecnologia utilizada, e de que a mesma está sujeita a uma ordem de controle e vigilância. Ignorar isso seria, conforme menciona Coco Fusco, como "se mais de quatro décadas de crítica pós-moderna do sujeito cartesiano tivessem evaporado de repente"129 (FUSCO apud TUTERS; VARNELIS 2008, p. 3, tradução nossa).

Um artista que vale destaque é Jeremy Wood, que trabalha também no perfil anotativo, mas diferente de Polak. Ele associa seu desenho de percurso a questionamentos ampliados, profundos e conscientes de conceitos e das normas nas quais está inserido. Wood considera em seu trabalho, e na articulação do mesmo, o caráter impositivo e imperialista citado por Holmes e Ben Russel.

"Eu faço mapas dos meus percursos para contribuir com o campo da

\footnotetext{
128 "[...]the individual wavering life-line appears at once as testimony of human singularity in time, and proof of infalible performance by the satellite mapping system. All too often in contemporary society, aesthetics is politics as decor." (HOLMES, 2003, s/n).

129 "It is as if more than four decades of post modern critique of the cartesian subject had suddenly evaporated" (FUSCO apud TUTERS; VARNELIS, 2008, p. 3).
} 
cartografia pessoal. $\mathrm{O}$ ato de traçar os movimentos será comum assim como é uma rica fonte de informações para empresas e governos." ${ }^{130}$ (WOOD, 2008, s/n, tradução nossa)

\subsection{QUATRO PROJETOS CONTRACARTOGRÁFICOS}

Para refletirmos e aprofundarmos na discussão de como artistas contemporâneos cartógrafos têm respondido em suas obras a questões como as levantadas por Holmes (2006) e Russel (2006), iremos nos debruçar em reflexões e leituras de propostas artísticas que trabalham nesse recorte, procurando associar criticamente temas como percursos e localização com as mídias locativas. Vale ressaltar que se optou por dois projetos realizados a partir do Brasil e outros dois realizados por artistas estrangeiros. Essa escolha se justifica para demonstrar que o pensar cartográfico na arte permeia fortemente não só o cenário internacional, mas também o nacional.

\subsection{1 - MERIDIANS (2005) - JEREMY WOOD}

Jeremy Wood, artista que se intitula "mapmaker", é um dos primeiros a explorar trabalhos artísticos com a tecnologia do GPS para explorar questões vinculadas a percurso, consciência de navegabilidade e percepção de espaço. Um dos principais interesses do artista é a qualidade estética do traçado do GPS, que é feito com a movimentação do seu corpo pelo espaço e os compara com as marcações realizadas nos mapas em papel.

A geógrafa Tracey P. Lauriant, no artigo GPS Tracings-Personal Cartographies, apresenta o artista como um narrador de uma cartografia pessoal “[...] onde ele, códigos, lugares e GPS são os protagonistas." (2009, p. 360, tradução nossa) ${ }^{131}$. A 'tela' do artista é o espaço, determina seu trajeto e como seu corpo vai responder ao percurso proposto, ou seja, a demarcação de seu percurso tem uma relação direta com obstáculos, intempéries e qualidade

\footnotetext{
130 "I make maps of my tracks to contribute to the field of personal cartography. The act of tracing ones movements will be commonplace as $i$ tis such a rich source of information for business and government" (WOOD, 2008, s/n)

131 “[...] Where he, codes, places and GPS are the protagonists.”(LAURIAULT, 2009, p. 360)
} 
do trajeto realizado.

O trabalho de Wood, apesar de possuir uma estética que, à primeira vista, parece ser lúdica, carrega em seu plano de fundo uma forte crítica quanto à falsa noção de precisão tecnológica locativa. O artista, em suas obras, com a utilização de mídias locativas, apresenta questionamentos sobre a real abstração do entendimento de localização a que temos acesso. Aponta que essas informações geolocativas não possuem uma precisão absoluta, mas sim relativa.

Em uma entrevista concedida ao curador Jeremy Hight em 2011, Jeremy Wood afirma que entende os dados geolocativos como ferramentas que auxiliam a apresentar lugares fictícios. O próprio artista questiona; “[...] não estou certo se nós sabemos exatamente onde as coisas estão.” (2011, s/n, tradução nossa).

As imprecisões inerentes a como o homem se localiza e localiza as coisas são destacadas no projeto Meridians (Londres, 2005). Este trabalho é uma performance de 737,89 km de distância caminhada em que "escreveu" uma citação textual de comprimento linear de 71,12 km. O projeto durou 3 meses e, durante sua execução, o artista enfrentou chuva, neve e sol, para que fosse completada. Consiste na escrita, pelo percurso do artista, de uma citação de Herman Melville :

\section{"It is not down in any map; true places never are" 132}

A citação elegida pelo artista, está longe de ser aleatória, ela é uma frase que descredita o mapa como registro de lugares reais. A citação elucida o questionamento da obra tanto de maneira literal quanto metafórica, pois o escrever dessa frase ao longo de dois meridianos parece confirmar o sentido literal da frase de Melville (Figura 52 e 53). Esses dois meridianos utilizados possuem uma função além do simples apoio referencial para o percurso: ambos foram demarcados e padronizados cientificamente. São eles: GMT e o GRS80.

132 Citação extraída da obra literária Moby-Dick (1851) do autor Herman Melville. Tradução: "Não está em nehmu mapa; lugares verdadeiros nunca estão" 


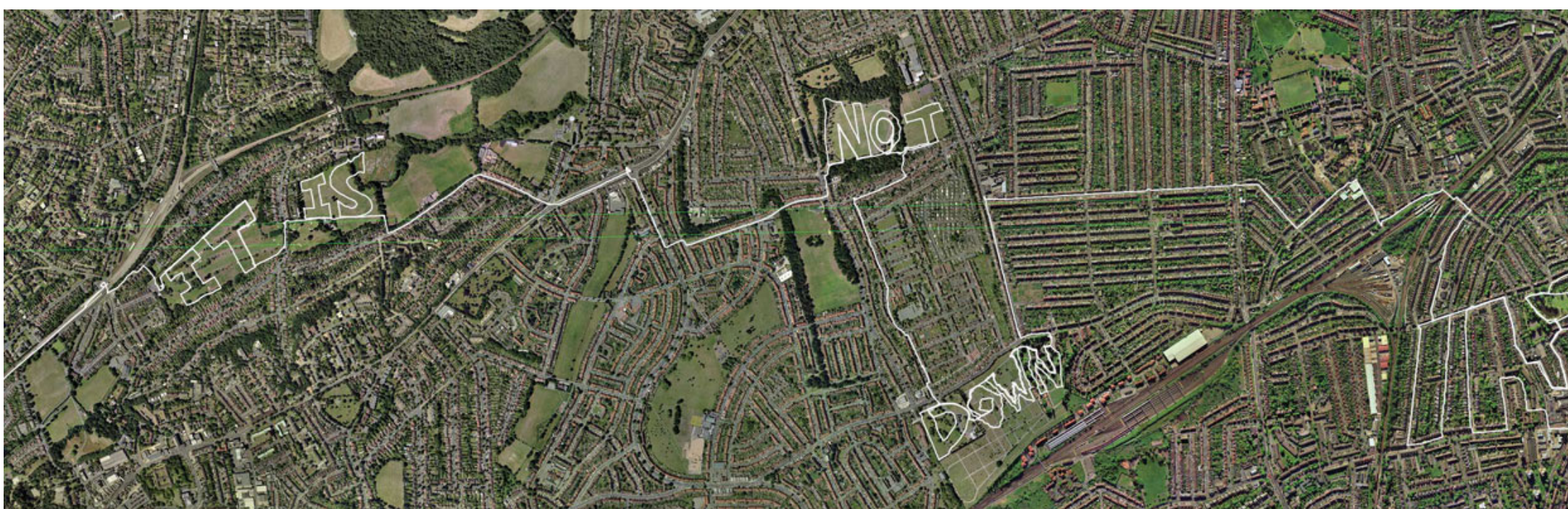

Figura 52 - Sobreposição de fotos de satélite da cidade de Londres e a trajetória do artista marcada com GPS em que se lê a citação. Fonte: gpsdrawing.com

O GMT (Greenwich Mean Time) foi estabelecido em 1884 por um acordo internacional como padrão da linha Meridiano que atribui o ponto zero de longitude. Este padrão assume que o formato da Terra é aproximado e baseado pela principal triangulação de dados britânicos (1783-1853). O outro padrão utilizado na obra de Wood é o WGS84 (World Geodetic System 1984) estabelecido 100 anos depois do GMT. Este é o padrão utilizado na tecnologia GPS, baseado no tempo atômico e suas coordenadas tridimensionais se utilizam do GRS80 elipsoide $^{133}$. O sistema GRS80 é mais complexo para calcular qualquer ponto locativo na Terra. No entanto, mesmo com toda sua complexidade de cálculos, ainda não é preciso. Como o próprio Jeremy Wood afirma: “Ambos (padrões) contam com a protuberância equatorial, mas nenhuma delas se encaixa perfeitamente na Terra." ${ }^{134}$ (2006, p. 274, tradução nossa)

Esses padrões, por mais que sejam aceitos pela ciência como referência locativa, não se coincidem, e esse desencontro confronta os entendimentos parciais de veracidade e certeza

133 GRS80- (Geodetic Reference System 1980) - GRS80 elipsóide : é uma superfície matematicamente definida que se aproxima do geoide, a verdadeira figura do planeta. Os elipsoides de referência são usados como uma superfície na qual são efetuados os cálculos da rede geodésica e são definidas as coordenadas de pontos tais como latitude, longitude e altitude.

134 Both account for the eqautorial bulge, but neither fits the Earth perfectly" (WOOD, 2006, p. 274) 


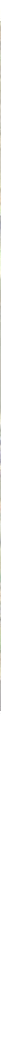

que temos das nossas referências espaciais locativas. Destacar, como o artista faz, o espaço entre as duas demarcações faz emergir uma série de indagações quanto à localidade das coisas e o que orienta o deslocamento do corpo no espaço.

“Esses dois padrões são marcados no meu desenho para indicar a escala de acordos entre o sistema local e o sistema mundial, já que as sensibilidades locais são mais confiáveis que projeções globais. Nossa navegação pessoal está evoluindo do olhar para cima e ver estrelas para olhar para baixo para dispositivos mediados por satélites que ficam na palma da mão. As duas linhas dos meridianos são bordas de mapas que não se encontram: entre eles há lugares que não existem. Com essa área de ajuste, o hemisfério Leste-Oeste não se encaixa." (WOOD, 2006, p. 274, tradução nossa) ${ }^{135}$

135 "These two standards are marked on my drawing to indicate a range of agreement between local and worldwide systems since local sensibilities are more trustworthy than global projections. Our personal navigation is evolving from looking up at the stars to looking down from satellites mediated by digital devices held in our palms. The two meridian lines are the edges of maps that don't meet up; between 
Ao longo do trajeto registrado via GPS pelo artista, é possível perceber variações de qualidade e distorções. Essas variações, segundo Wood, refletem a natureza do ambiente que foi demarcado. Em outras palavras, refletem desde desafios topográficos, até localização de objetos, acontecimentos locais e o significado histórico do local.

"Ver os ritmos e padrões do trajeto de alguém pode ter o efeito de ver seu próprio fantasma. A qualidade das linhas desenhadas em um GPS pode revelar muito sobre movimento e processo. Assim como o desenho de um lápis onde linhas delicadas possuem diferentes velocidades em bordas irregulares...” (WOOD, 2008, tradução nossa) ${ }^{136}$

Vale atentar igualmente para o local onde cada palavra da citação escrita foi demarcada ao longo do percurso. $\mathrm{O}$ artista programou seu percurso ao longo das linhas imaginárias, mas também programou a região específica onde cada palavra seria marcada. Segundo o relato do próprio artista, a marcação da primeira palavra ' $I t$ ' (Figura 54) passou por um campo de golf, o que exigiu uma longa negociação com a administração local. Apesar de em alguns lugares o artista precisar negociar passagem e acessos, ele também burlou algumas barreiras para que mantivesse as linhas retas e/ou curvas necessárias para garantir o formato da letra e sua legibilidade ao final do percurso.

A partir das figuras, é possível também extrair uma leitura de cada palavra relacionada à sua localização marcada com as fotos de satélite correspondente. A primeira delas, 'It', um pronome neutro que indica a existência de algo, começa por atravessar os meridianos. A seguinte, o verbo 'is'(Figura 55), que significa ser/estar, se encontra sublinhada pelo meridiano Greenwich, como se o verbo estivesse afirmando/confirmando algo que, na realidade, é a própria defasagem de posição entre os meridianos abaixo. A palavra seguinte (Figura 56), uma partícula de negação 'not' (não) já se encontra afastada e acima dos meridianos, em uma área em que não há muitas construções - ao fundo de uma escola.

them are places that don't exist. Within this area of adjustment, the east-west hemispheres cannot be straddled. (WOOD, 2006, p. 274) 136 "seeing the rhythms and patterns of ones tracks [that] have the affect of seeing your own ghost. The qualities of line in GPS drawings can reveal a great deal about movement and process. Just like a pencil drawing where smooth lines have a different speed to jagged edges..." (WOOD, 2008) 

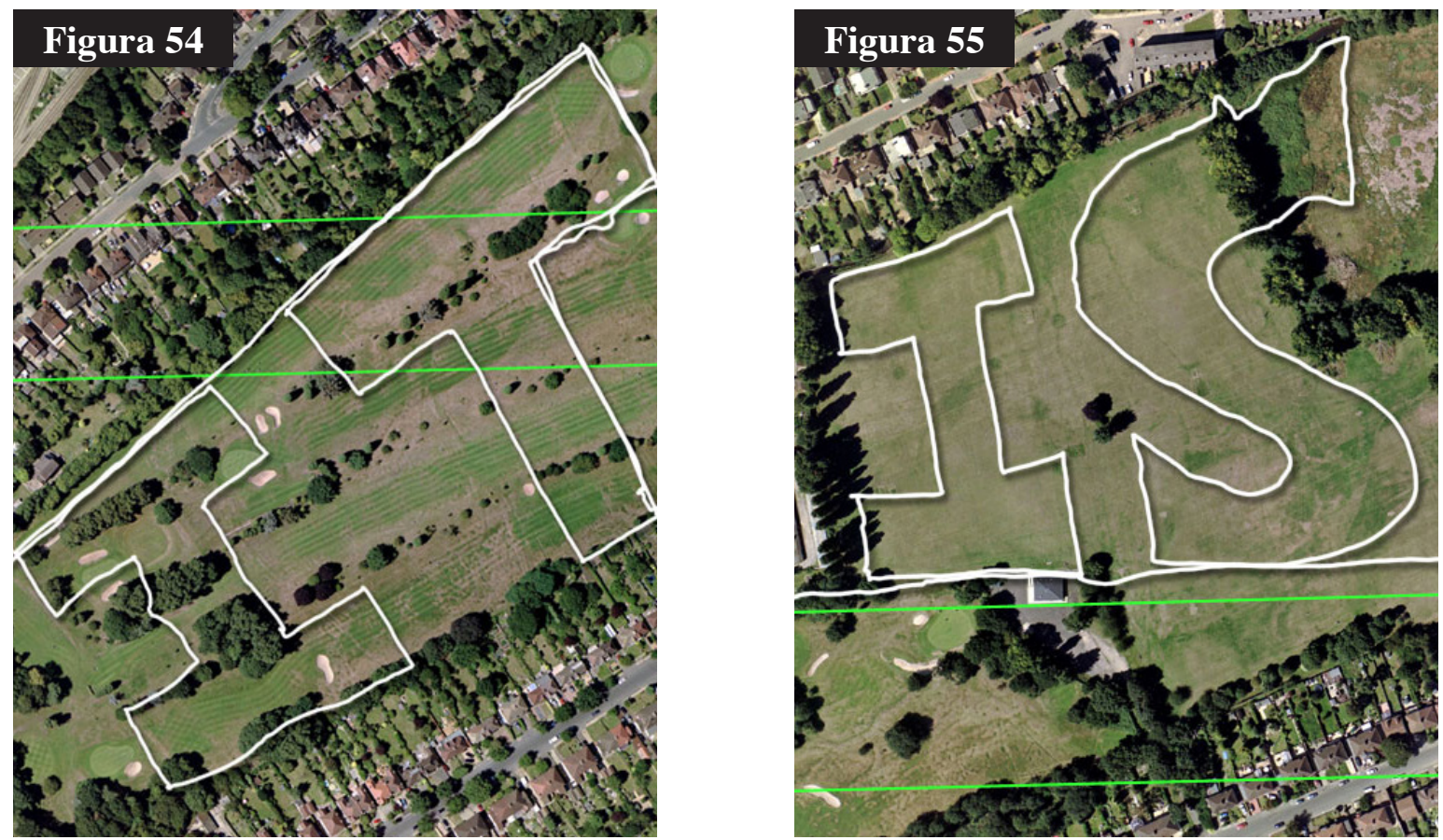

Figura 54-Marcação da primeira palavra ' $I t$ ' que passa por um campo de golf. I Figura 55- "is" é sublinhada pela linha do meridiano Greenwich. I Figura 55-A palavra "not" foi escrita parte em um parque e parte em um fundo de escola. Fonte: gpsdrawing.com.

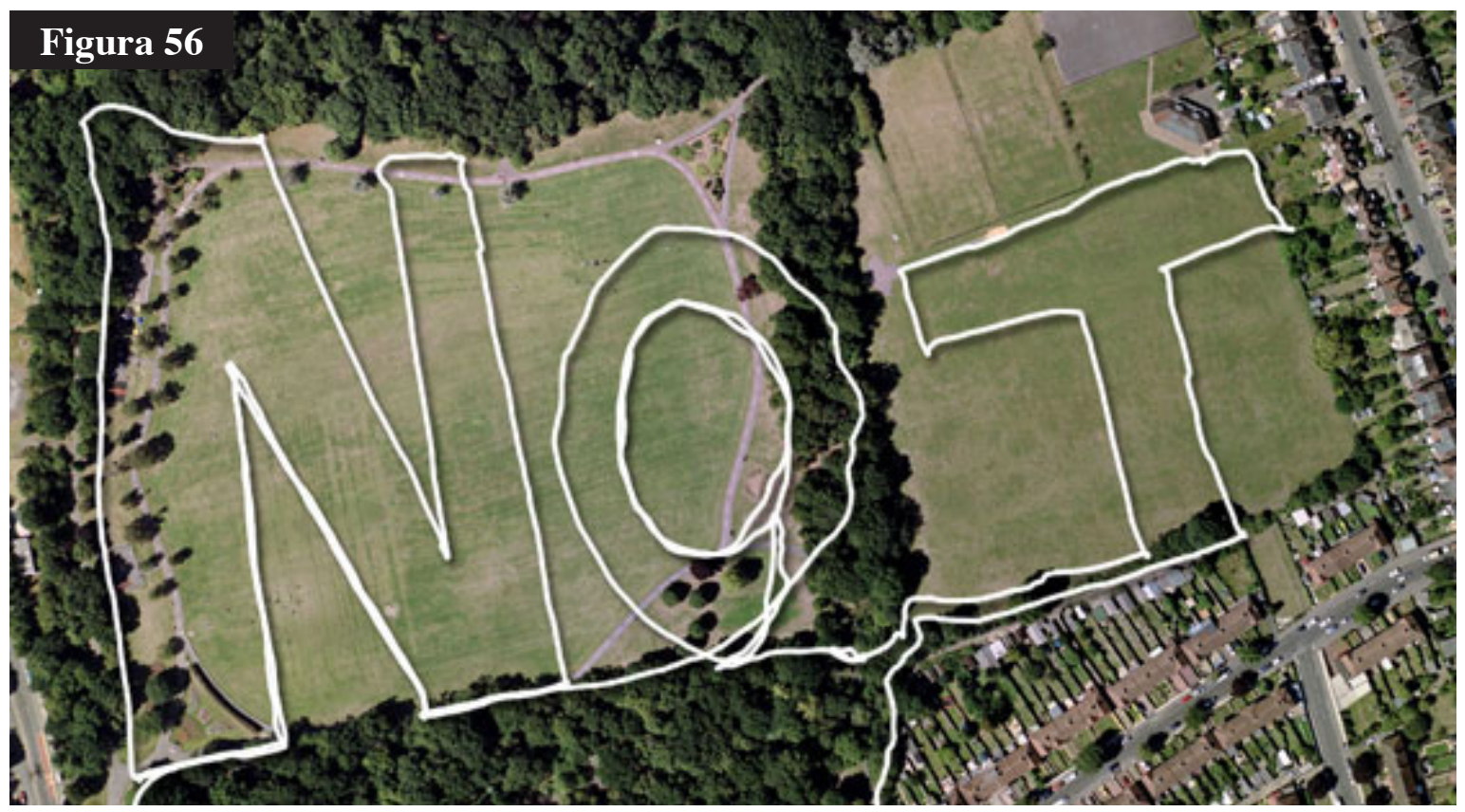


Em seguida (Figura 57), o artista demarca a palavra 'down' (abaixo), que indica duas situações: a palavra está 'abaixo' da “pauta” dos meridianos, além, é claro, de estar exatamente 'escrita' em um cemitério - onde localizamos o que está abaixo da terra. Após essa palavra, o artista retoma a altura dos dois meridianos e percorre em um 'zigue- zague' na faixa entre eles. Após esse percurso entre os meridianos, o artista percorre a palavra 'in' (dentro) que está em uma área estritamente residencial, referenciando a residência como o local mais interno em que se habita.

Após a palavra 'in'(Figura 58), o artista retoma o caminhar entre os dois meridianos até que, ainda entre os meridianos (Figura 59), escreve, ou melhor, grifa a palavra 'any' (qualquer). Neste momento, o artista opta por alterar a forma de escrita utilizada até então; passa a escrever com fontes conformadas apenas por uma linha sob uma área ampla e gramada. $\mathrm{O}$ fato de boa parte desta palavra estar no espaço entre os meridianos reforça o questionamento do que esse espaço de desencontro significa.

Ao escrever a palavra 'map' (mapa) (Figura 60), o artista retorna à região abaixo dos dois meridianos, em uma área livre. No entanto, apesar de ter sido programada para estar em uma área livre gramada, o artista encontrou obstáculos como um circo, o que gerou uma distorção da letra da palavra. Já as palavras 'true places' (lugares verdadeiros) se localizam bem rentes aos meridianos (Figura 61); 'true' fica rente e sublinhado pelo meridiano de de Greenwich enquanto a palavra 'places' fica rente e logo abaixo do meridiano GPS. Como que indicando, até de forma irônica, que os verdadeiros lugares são os que são validados pelos meridianos e, de forma indireta, negando o espaço entre eles como a demarcação ou existência de um lugar verdadeiro/existente.

As últimas palavras 'never are' (nunca são) encerram o trajeto em um estacionamento que tangencia o Millenium Dome - segundo Jeremy Wood, um complexo muito curioso. $\mathrm{O}$ Millenium Dome é uma construção feita para celebrar a chegada do século XXI; no entanto é rodeada por grades, corredores, bicicletários e estacionamentos vazios (Figura 62). Como J. Wood afirma em seu texto, escrever neste espaço demandou resolver uma série de obstáculos devido a uma obra que acontecia. Ao terminar a frase, o artista seguiu ao norte na altura 

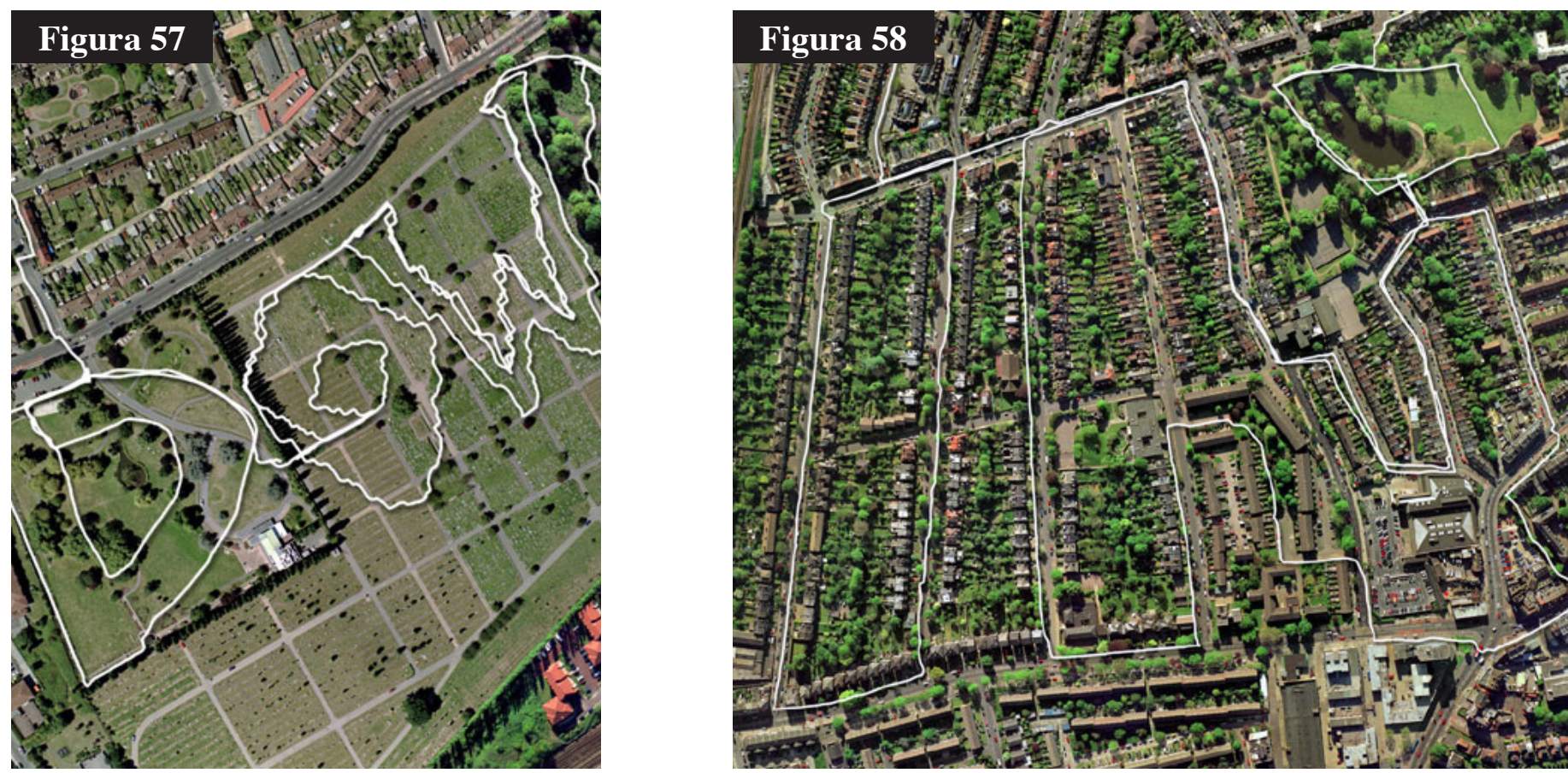

Figura 57- "down" foi escrito em um cemitério, além de estar marcada abaixo das linhas dos dois meridianos. I Figura 58- A palavra "in" foi escrita em uma área residencial. I Figura 59- a palavra "any" foi escrita num formato mais simples, além de metade da palavra estar bem entre os meridianos. Fonte: http: gpsdrawing.com.

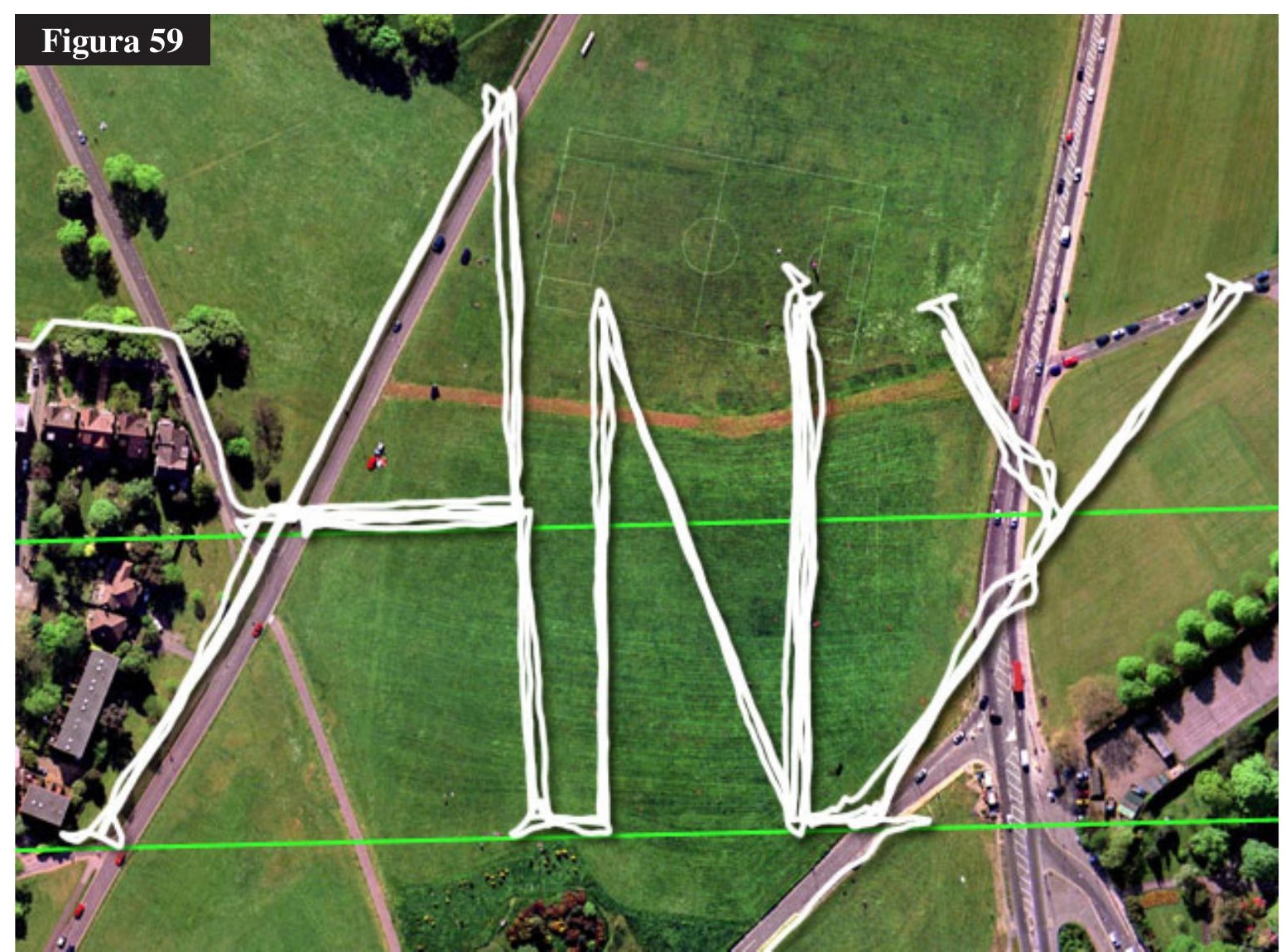




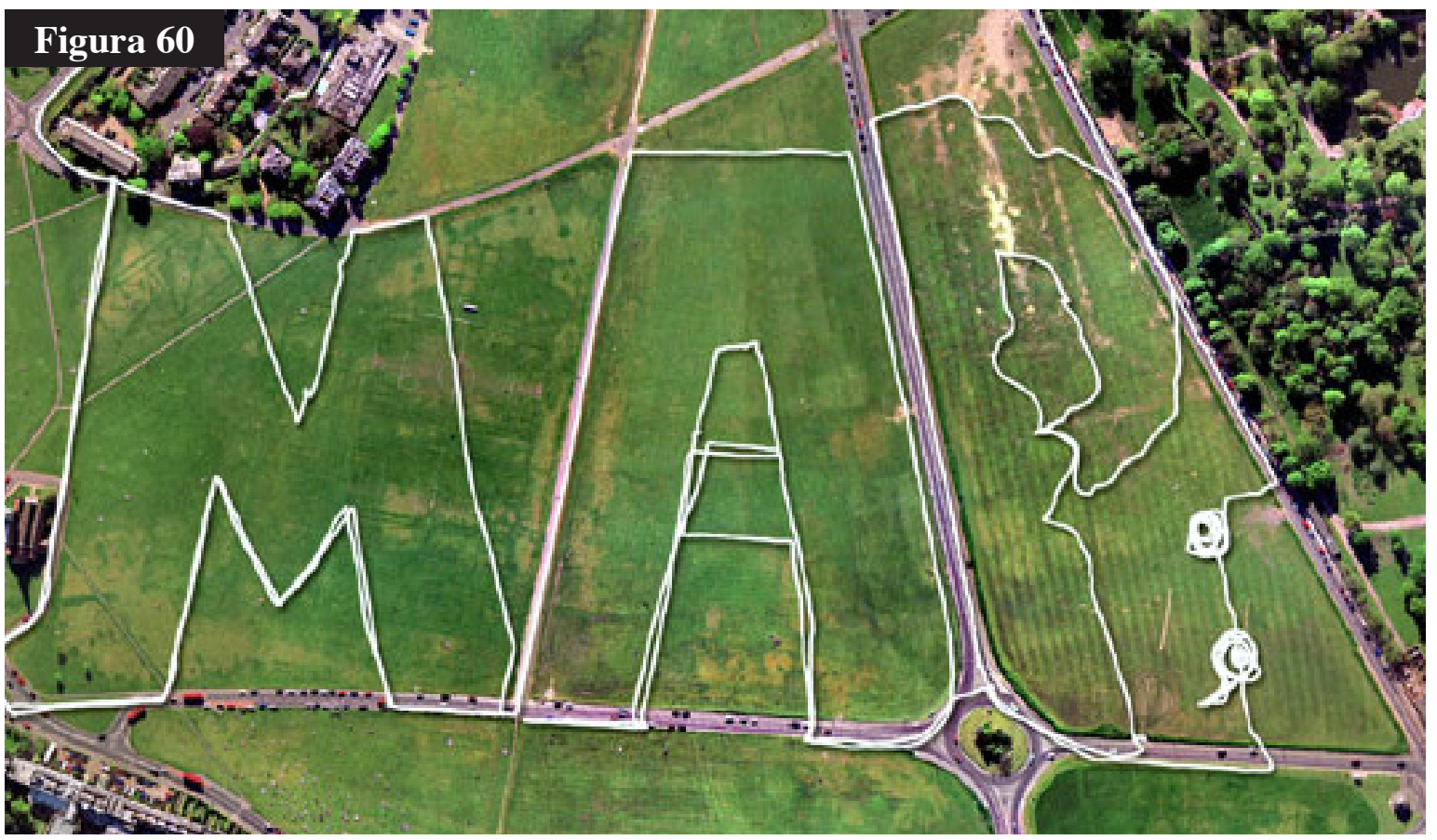

Figura 60-"map" é desenhada em uma área que, de início, era para ser completamente livre e aberta, mas no dia da execução havia um circo montado, o que gerou uma distorção na palavra. I Figura 61-"true places" da citação se encontram em Greenwich Park - local estabelecido como padrão em 1884 para marcação global de tempo e espaço. Fonte: gpsdrawing.com.

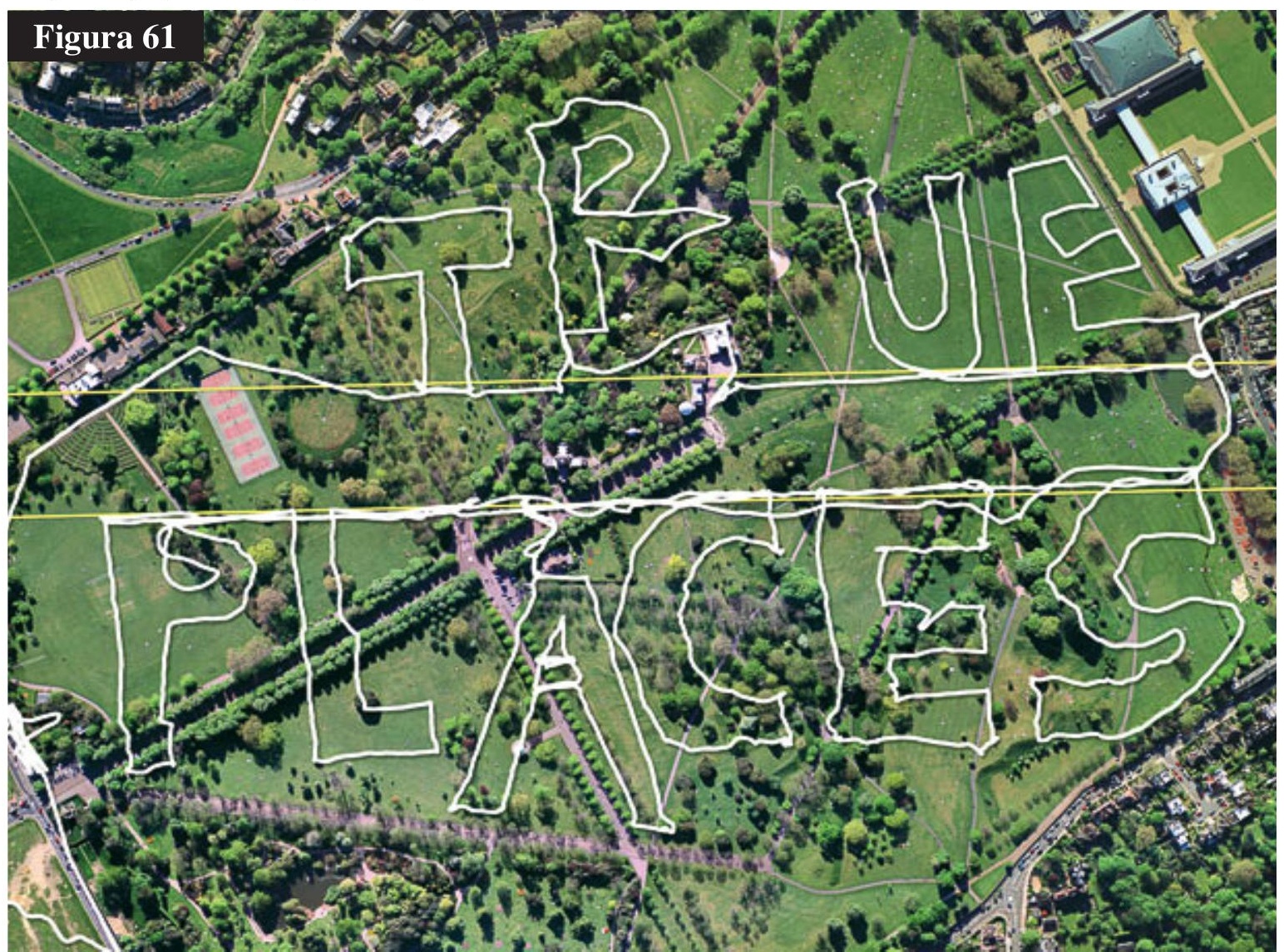




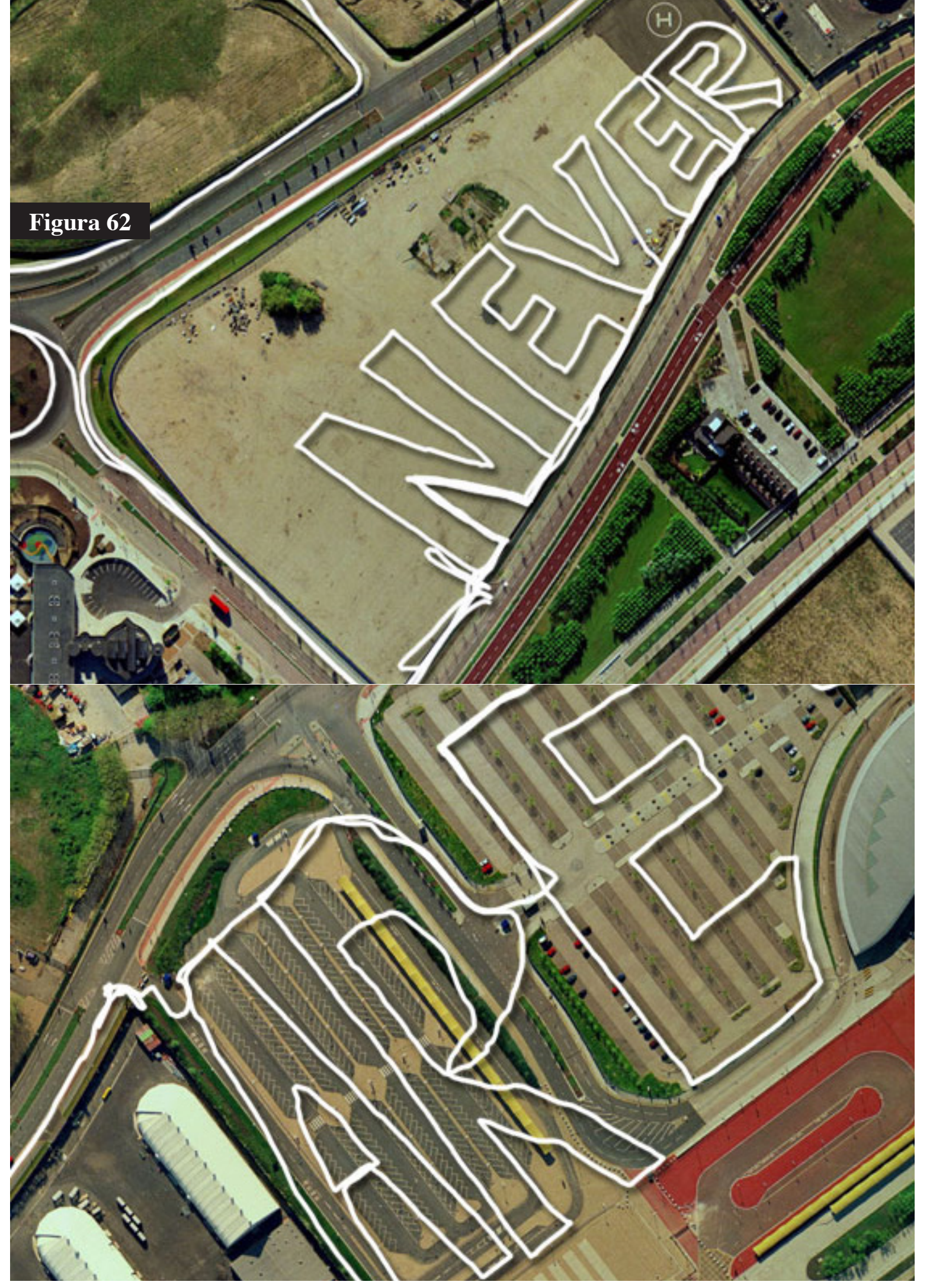

Figura 62- As palavras finais "never are" estão traçadas num estacionamento adjacente ao "Millenium Dome”. Fonte: gpsdrawing.com. 
máxima que o terreno permitia, um píer, que está exatamente no meridiano de Greenwich.

A cartografia para Jeremy Wood é uma forma de narrativa, de uma narrativa pessoal. Com o projeto Meridians, Wood, questiona a precisão tecnológica, ou seja, como coisas estão posicionadas e estão imprecisas do ponto de vista do GPS.

Meridians é um trabalho que acontece a partir da emissão de dados do sujeito (o artista que percorre o trajeto) para um conjunto de dados de uma nuvem informacional maior, uma vez que acontece a sobreposição com fotos de satélites e associações com coordenadas GPS que registram as linhas percorridas. Uma outra questão importante a se notar é que o artista, apesar de subverter o uso do GPS, utilizá-lo para desenhar/escrever, também opta por linguagens cartográficas relativamente comuns e de fácil leitura para questionar conceitos/ valores.

Wood aponta com Meridians a falha ou o desencontro entre os dois padrões locativos. Traz uma reflexão crítica do que assumimos como realidade e questiona, de forma direta, a noção de localização que é tomada pelo senso comum como absoluta e verdadeira. Lauriault sintetiza bem a obra Meridians: "Eu sei onde estou, é aqui, na verdade, mas não consigo precisamente te dizer exatamente onde"137 (2009, p.361, tradução nossa)

137 "I know where I am, it is here, really, but I can’t precisely tell you where exactly" (WOOD, 2009, p.361) 


\subsection{2 - MONOCHROME LANDSCAPES (2004) - LAURA KURGAN}

Laura Kurgan traz aproximações distintas em suas obras. Além de possuir uma forte formação e carreira acadêmica, é profunda entendedora dos mecanismos de imagens de satélite, e objeto de inúmeras exposições realizadas nos EUA e Europa. No livro, 'Close Up at a Distance' em que apresenta 9 trabalhos de sua autoria, Kurgan ressalta:

"Esses projetos expõem os materiais que trabalham para poder recuperar, reutilizar e descobrir seus usos inadvertidos, algumas vezes críticos e, muitas vezes, proposicionais. Podem ser usados para documentar, memorizar, preservar, interpretar e politizar ou simplesmente como dispositivos estéticos, mas assim como todos os mapas, os que estão aqui - assim como os conjuntos de dados e a tecnologia que os lista - não são neutros." 138 (KURGAN, 2013, p. 17, tradução nossa)

Neste momento, trataremos do projeto Monochrome Landscapes, por ser uma significativa obra de Kurgan e lidar diretamente com a densidade informacional contida em uma imagem georreferenciada. A obra, segundo Kurgan, é um referência direta e formal à obra 'Four Panels' (1970-71) do artista Ellsworth Kelly (Figura 63), que fez parte do movimento 'Color Field' nos Estados Unidos. Movimento este em que a cor é o foco principal e as formas, texturas, gestos e pinceladas deixam de ser parte da discussão. Uma abstração que articula os campos de cores e a percepção do observador, sendo que sua distância em relação aos painéis coloridos é determinante para compreensão da abstração ali representada. Apesar de os dois artistas trabalharem com paletas de cores diferentes, a forte relação entre elas é o grau de abstração que apresentam. Enquanto a obra de Ellsworth Kelly é composta por painéis impressos com tinta, a de Kurgan é conformada por grandes fotos de satélites impressas. Nessas fotos de altíssima resolução, Kurgan trabalha diferentes graus de abstração ou profundidade informacional presentes nelas, conforme o aumento do zoom, ou em uma leitura atenta em cada uma delas.

138 "These projects expose the materials they work with in order to reclaim, repurpose, and discover their inadvertent, sometimes critical, often propositional, uses. They can be used to document, memorialize, preserve, interpret, and politicize, or simply as aesthetic devices, but as with all maps, the ones here - as well as the data sets and Technologies used to chart them - are not neutral.” (KURGAN, 2013, p. 17) 

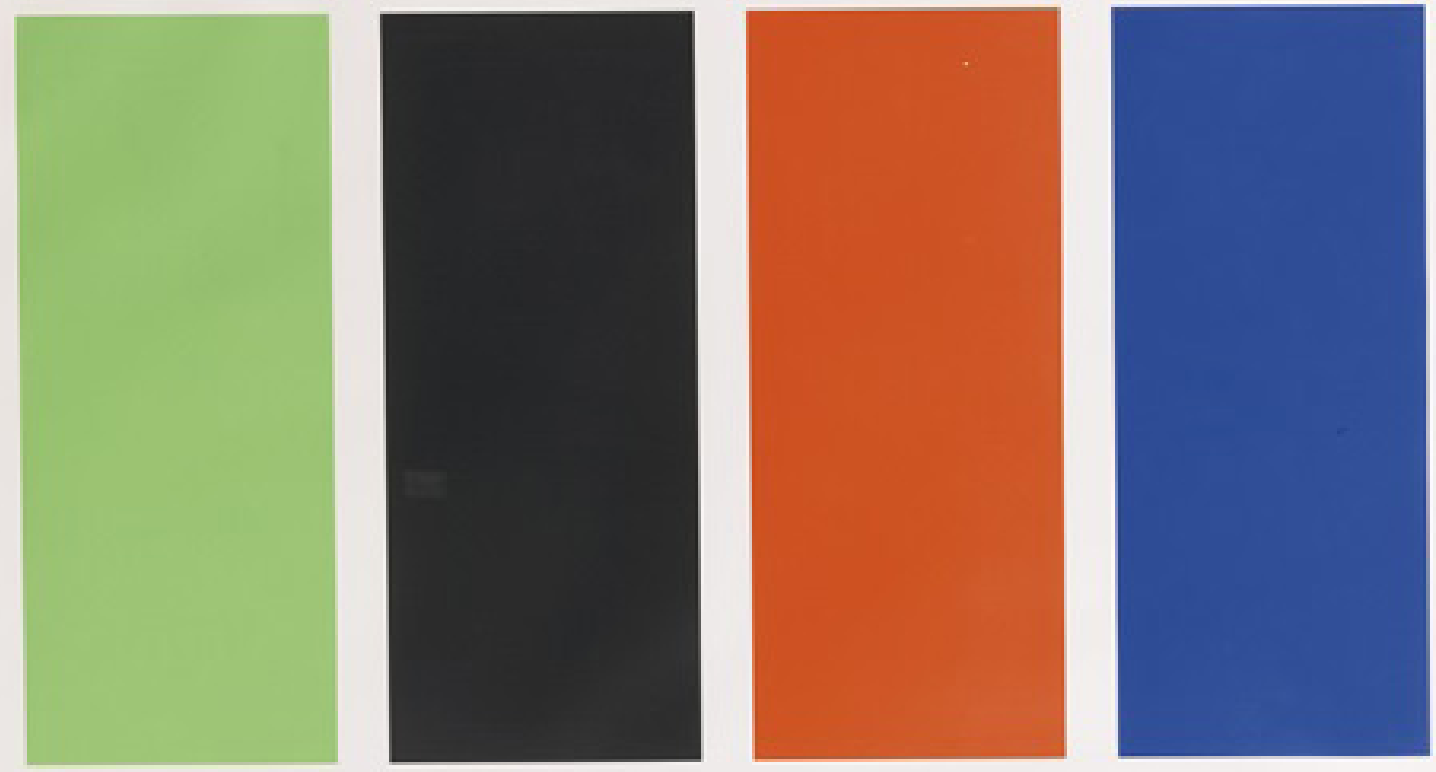

Figura 63- 'Four Panels' (1970-71) do artista Ellsworth Kelly. Fonte: artnet.com.

Os monochromes de Kurgan (Figura 64) são branco, azul, verde e amarelo respectivamente e foram exibidos em grandes painéis impressos de dimensão de aproximadamente $1 \mathrm{~m}$ x $2 \mathrm{~m}$ (40'x80'). As fotografias, que mostram pontos diferentes da Terra, foram capturadas pelos satélites Ikonos $^{139}$ e Quickbird ${ }^{140}$ em altíssima resolução. Vale ressaltar que cada foto comprada pela artista corresponde a um quadrado de $8 \mathrm{~km} \times 8 \mathrm{~km}$. Duas delas foram adquiridas dos arquivos do DigitalGlobe (satélite Quickbird) e uma, encomendada na mesma empresa. A foto verde, por sua vez, foi encomendada do Satélite Ikonos.

Cada foto, devido ao grau de abstração alcançado pela predominância de uma única cor e o grau de zoom escolhido, aparenta ser composta apenas por cores vibrantes com uma leve textura. Kurgan determinou primeiro as cores básicas que gostaria que compusessem a obra (branco, azul, verde e amarelo), o que naturalmente levou à escolha de pontos com

139 Satélite Ikonos é um satélite privado, pertence e é operado por Space Imaging, Inc. Empresa de Thornton- Colorado (EUA). O Satélite consegue produzir fotos de resolução de até $1 \mathrm{~m}$ por pixel.

140 Satélite Quickbird pertence a DigitalGlobe Inc.De Longmont,-Colorado (EUA). O satélite consegue produzir fotos de resolução de $0,6 \mathrm{~m}$ por pixel. 
predominância de neve, água, árvores e areia, respectivamente. No entanto, ao se atentar em cada foto, percebe-se que elas trazem mais do que simples cores, padrões, texturas dos elementos naturais predominantes. Há camadas de entendimento muito mais profundas do que aparentam, aspecto este que remete às pinturas color field. No caso dos Monochromes de Kurgan, mais que a formalidade estética da obra, o que conta é a carga política, ecológica e militar que estas fotos revelam.

"Eu estava interessada na ideia de que os lugares na Terra que aparecessem de cima como mais ou menos uma única cor também fossem lugares que eram contestados, frágeis e submetidos a aparelhos de vigilância cada vez mais detalhados." 141 (KURGAN, 2013, p. 153, tradução nossa)

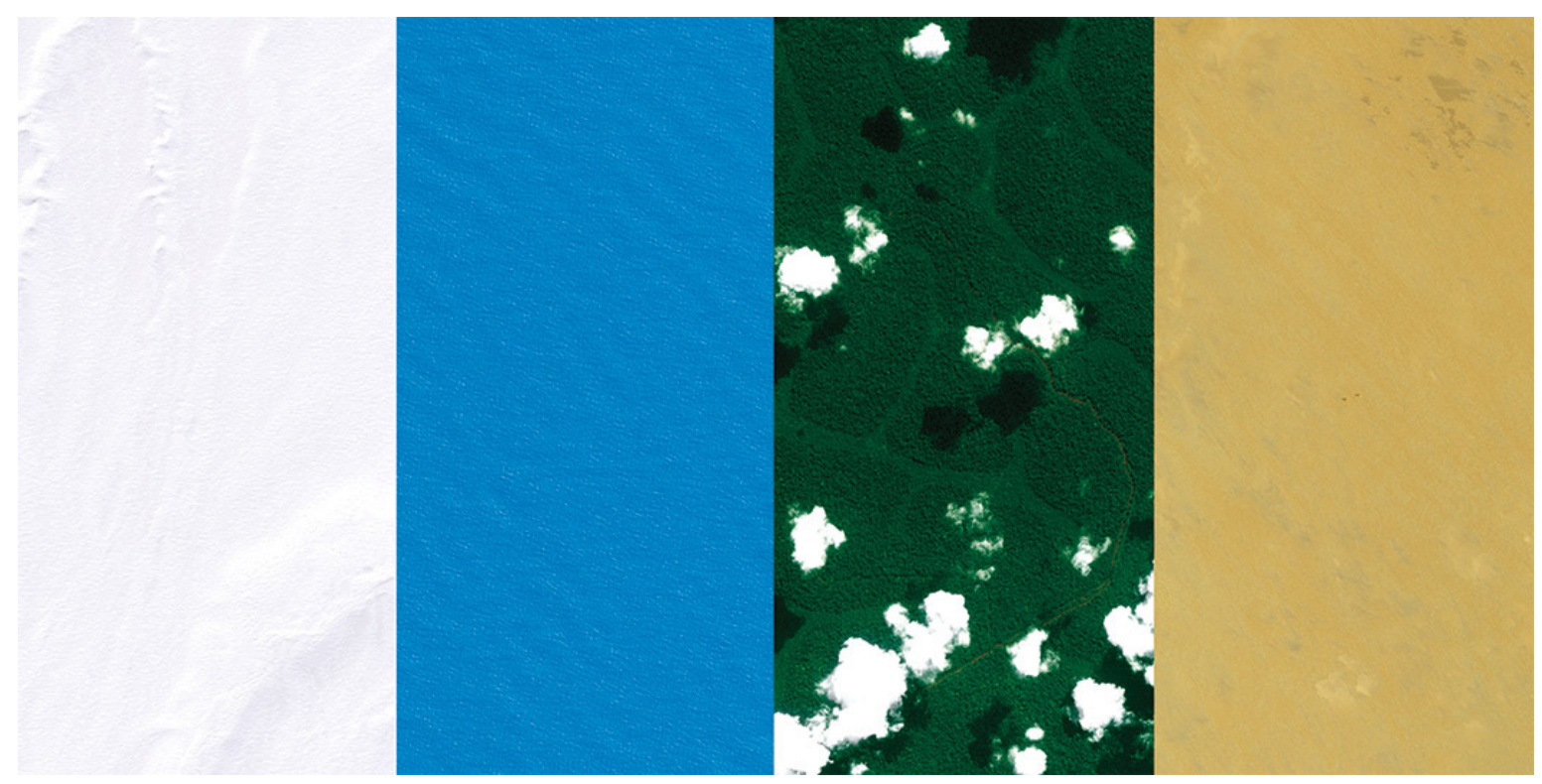

Figura 64- Monochrome Landscapes. Fonte: Close Up at a Distance.

Cada imagem envolve diferentes tensões políticas, ambientais e até mesmo econômicas. No livro "Close Up at a Distance", Kurgan explica que cada painel demonstra como uma foto de alta resolução com recursos de aproximação de zoom pode conter diversas camadas

141 "I was interested in the idea that places on Earth that appeared from above as more or less a single color were also places that were contested, fragile, and subjected to increasingly thorough survaillance apparatus.” (KURGAN;2013:153) 
como "[...] informação, superfície, padrões, caso de encontros, evento, memória, campo de cores." ${ }^{142}$ (2013, p. 153, tradução nossa)

\section{BRANCO}

1002 area, Artic National Wildlife Refuge (ANWR), near Kaktovik, Alaska.

Acquired: April 7, 2003, 21:12:49 GMT.

Center coordinates: $69^{\circ} 47^{\prime} 59.46^{\prime \prime} \mathrm{N}, 144^{\circ} 32^{\prime} 33.9^{\prime \prime} \mathrm{W}$.

QuickBird satellite, 0,61 m per pixel.

O painel de cor branca (Figura 65) representa uma área do Alaska, mais precisamente de uma área identificada como Artic National Wildlife Refuge (ANWR). Uma área que sustenta uma tensão política ativada especialmente no período do Governo Bush. A tensão acontece, pois, além de a área abrigar uma ampla variedade de animais como ursos polares, musk $o x$, caribou e diversas espécies de aves, ela também abriga uma expressiva quantidade de petróleo bruto (o equivalente a 10.4 bilhões de barris). Parte da ANWR se tornou uma área protegida desde a administração de Eisenhower (1960), e a outra parte desde 1980 pelo Alaska National Interest Lands Conservation Act (ANILCA).

Durante o governo Bush, tentou-se liberar a exploração de petróleo na região, no entanto, a medida foi barrada no Senado norte americano. Esse momento, inclusive, coincide com o início da Operação Iraqi Freedom. O debate acerca desta região específica é intensa, perdura até os dias atuais e ocorre na esfera política, econômica e inclusive ecológica.

142 “information, surface, pattern, chance encounter, event, memory, field of color."(KURGAN, 2013, p. 153) 


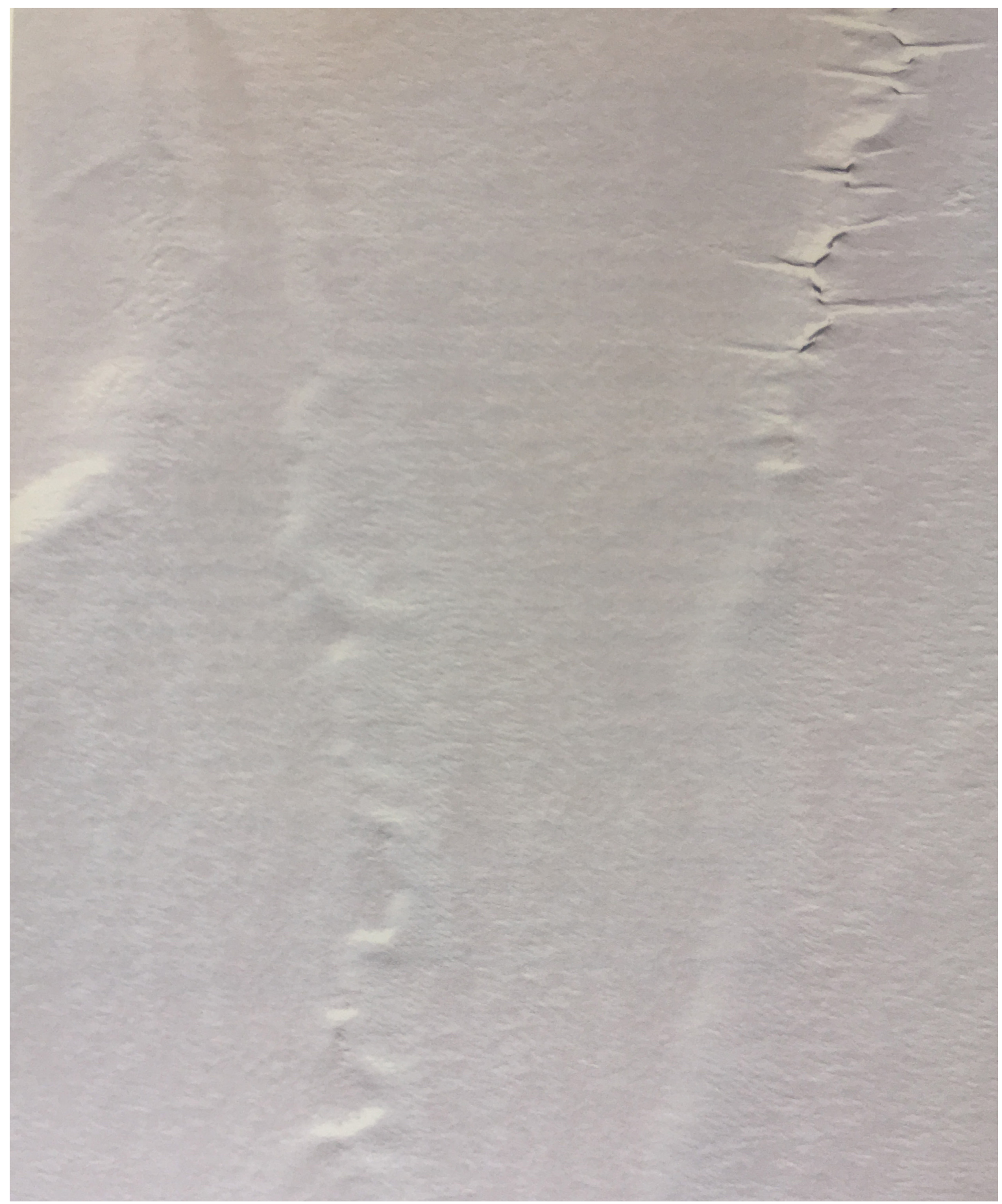

Figura 65- Branco. Área 1002, Artic National Wildlife Refuge, região próxima a Kaktovik-Alasca (Zoom 1). Fonte: Close Up at a Distance. 
AZUL

Atlantic Ocean, intersection of the Equator and the prime meridian, South of Accra (Ghana) and West of Libreville (Gabon)

Acquired: May 16, 2003, 10:19:54 GMT.

Center coordinates: $0^{\circ} 0$ '7.02" N, 00'1.62”'E.

QuickBird satellite, 0,61 m per pixel.

As coordenadas da foto azul (Figura 66) são; Latitude -0.00195 e longitude -0.00045. Kurgan procurou fotografar o ponto zero da cartografia atual. A latitude zero foi estabelecida há muito tempo atrás com o desenvolvimento da astronomia, no entanto, estabelecer o ponto 0.0 advém da cartografia moderna, quando foi necessário representar o mundo em uma grid abstrata. Cada representação e projeção fez uso de uma grid, de acordo com seu contexto político. A projeção de Mercator, por exemplo, citada no primeiro capítulo deste trabalho, faz o uso de uma grid que favorece cálculos e usos para navegação. Podemos citar, para ilustrar também a projeção de Peters, que com a uma outra grid procura trazer uma precisão política, gerando 'distorções' outras da habitual.

Atualmente, a cartografia digital também padronizou uma grid, na qual o espaço é medido em duas dimensões de $0 ; 0$. Kurgan ressalta como a realidade é constituída por uma representação complexa:

"Uma rede de relógios atômicos, câmeras e computadores construíram um globo virtual no qual, em qualquer ponto do espaço físico é facilmente coordenado com o espaço digital"143 (KURGAN, 2013, p. 17, tradução nossa)

143 "A network of atomic clocks, câmeras, and computers has built a virtual globe on which any point of physical space is easily coordinated with digital space.” (KURGAN;2013:17) 


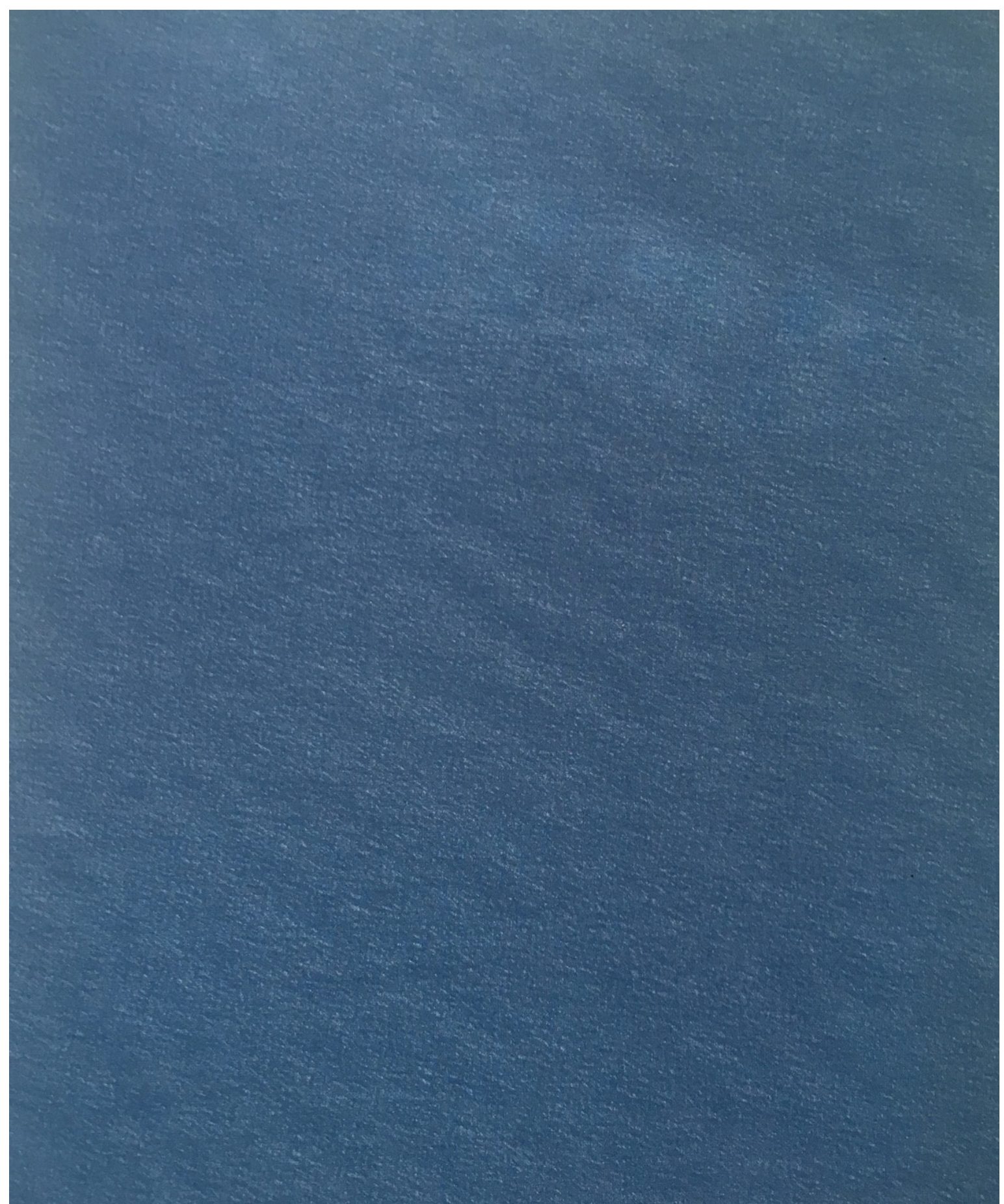

Figura 66- Azul. Oceano Atlântico, intersecção da linha do Equador com o Meridiano principal, região próxima a Ghana e oeste de Gabon. (zoom 1). Fonte: Close Up at a Distance. 
Kurgan, para destacar o interesse de trazer exatamente essa imagem do ponto zero, ressalta que, em janeiro de 2011, o 'Natural Earth'144 (um conjunto de dados de mapas de domínio público) lançou as diretrizes da versão 1.3 para cartógrafos e produtores de mapas de todo o mundo. Essas diretrizes trazem dados vetoriais de uma grid padronizada para livre produção de outros mapas. E o que chamou mais atenção de Kurgan é que, em meio ao lançamento desta versão, a 'Natural Earth' fez uma intrigante ressalva:

"ATENÇÃO: Foi adicionado um país com uma classe de soberania indeterminada chamada 'Null Island'. É uma ilha ficcional de 1 metro quadrado, localizada na África, onde o equador e o principal meridiano se cruzam. Sendo centrado em 0,0 (latitude zero e longitude zero), é útil para sinalizar falhas de geocódigo que são encaminhadas para 0,0 pela maioria dos serviços de mapeamento (... ) 'Null Island' em 'Natural Earth' é escala 100, indicando que nunca deve ser mostrado no mapeamento. ${ }^{145 "}$ (NATURAL EARTH DATA, 2011, s/n, tradução nossa)

Neste mesmo texto, o 'Natural Earth' também explica o gigantesco espaço de armazenamento de dados que seria necessário, se somente a 'Null Island' fosse mapeada na escala 1:1: seriam necessários mais de 3.5 bilhões de megabytes. Esta passagem remete ao conto mencionado no primeiro capítulo de Jorge Luis Borges (Do Rigor na Ciência) em que o imperador pede por um mapa $1: 1$.

A imagem azul representa a abstração máxima do processo de mapeamento, para o qual, aliás, foi necessário um país fictício de $1 \mathrm{~m}^{2}$. Essa imagem, por sua vez, parece remeter ao mapa (Figura 67) do conto 'Caça ao Snark' de Lewis Carroll, em que o líder entrega

144 Natural Earth: é um conjunto de dados do mapa de domínio público disponível em escalas de 1:10m, 1: 50m e 1: 110 milhões de escalas. Com dados vetoriais e vetores bem integrados, com a Natual Earth você pode criar uma variedade de mapas visualmente agradáveis e bem elaborados com cartografia ou software GIS. Este banco de dados é construído através da colaboração de muitos voluntários e é apoiada pela NACIS (Sociedade Norte-Americana de Sociedade Cartográfica). (fonte: http://www.naturalearthdata.com)

145 WARNING: A troubleshooting country has been added with an Indeterminate sovereignty class called Null Island. It is a fictional, 1 -meter square island located off Africa where the equator and prime meridian cross. Being centered at 0.0 (zero latitude and zero longitude) it is useful for flagging geocode failures which are routed to 0.0 by most mapping services...Null Island in natural earth is scale rank 100, indicating it should never be shown in mapping. (http://www.naturalearthdata.com/blog/natural-earth-version-1-3-release-notes/) 


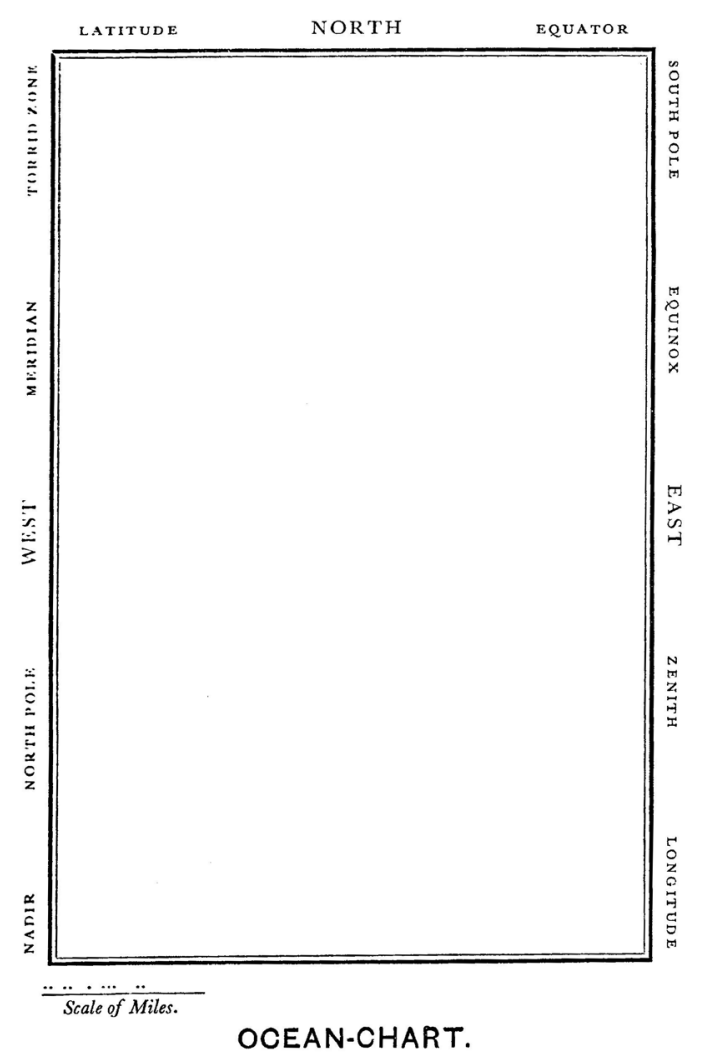

He had brought a large map

representing the sea,

Without the least vestige of land:

And the crew were much pleased

when they found it to be

A map they could all understand.

- Lewis Carroll,

The Hunting of the Snark

Figura 67- The Hunting of the Snarck - Lewis Carroll

Fonte: You Are Here-Personal Geographies and Other Maps of the Imagination 
o mapa à tripulação que, durante a caça da criatura mitológica (Snarck), se encontra no meio do oceano e fica aflita por não ter alguma referência. Ao se depararem com o mapa, se tranquilizam. Pelo que o conto mostra, os mapas podem representar qualquer coisa, inclusive um lugar não existente ou não conhecido ainda. São abstrações como essas que sustentam o nosso senso de localização e de segurança de se estar em um lugar.

\section{VERDE}

Old-growth tropical lowland rain forest, cameroon, about $100 \mathrm{~km}$ West of Yokadouma and $70 \mathrm{~km}$ east of the Dja reserve.

Acquired: December 4, 2001, 09:48 GMT.

Upper left coordinates: $3^{\circ} 13^{\prime} 9.804^{\prime \prime} \mathrm{N}, 14^{\circ} 12^{\prime} 27.72^{\prime \prime} \mathrm{E}$.

Ikonos satellite, $1.0 \mathrm{~m}$ per pixel.

A foto verde (Figura 68) corresponde a uma pequena seção de uma floresta localizada em Camarões (África) tirada pelo satélite Ikonos. Kurgan, para escolher a área verde, contou com a orientação da ONG Global Forest Watch $^{146}$ e, de forma indireta, se tornou uma investigadora para eles.

A princípio, a imagem era apenas uma imagem de um local verde ameaçado, especialmente pelo desmatamento ilegal. No entanto, ao observá-la com maior atenção, percebe-se que, em meio a toda a bela textura verde, é possível notar uma discreta estrada (Figura 69), que à primeira vista parece inocente, mas ao questioná-la e investigar mais, descobriu-se que se trata de uma estrada ilegal provavelmente utilizada para tráfego de madeiras oriunda do desmatamento ilegal.

Com uma foto de qualidade tão alta como estas de satélite, naturalmente buscamos ler e 


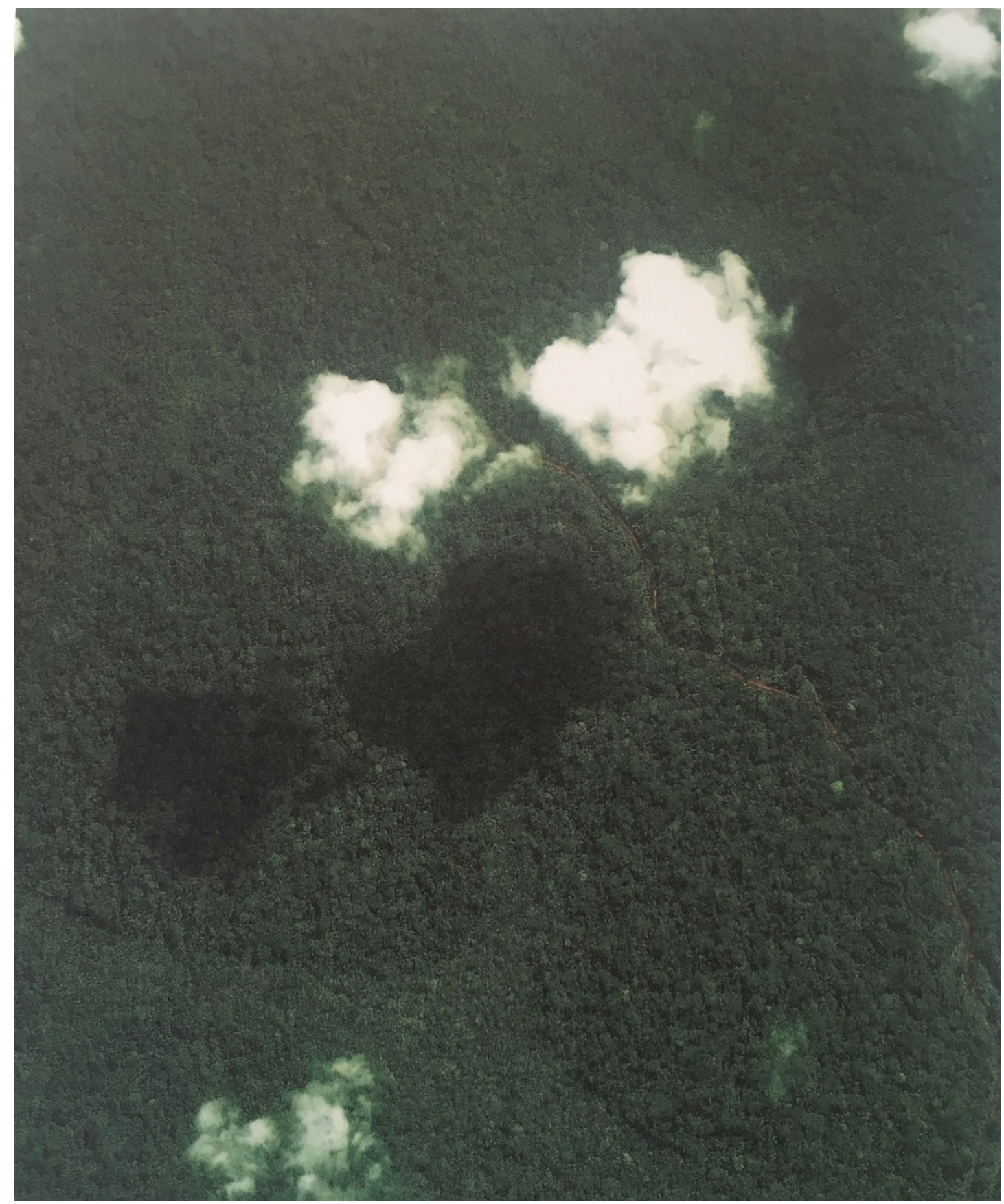

Figura 68- Verde. Floresta de planície tropical, sudeste de Camarões (zoom 1).

Fonte: Close Up at a Distance. 


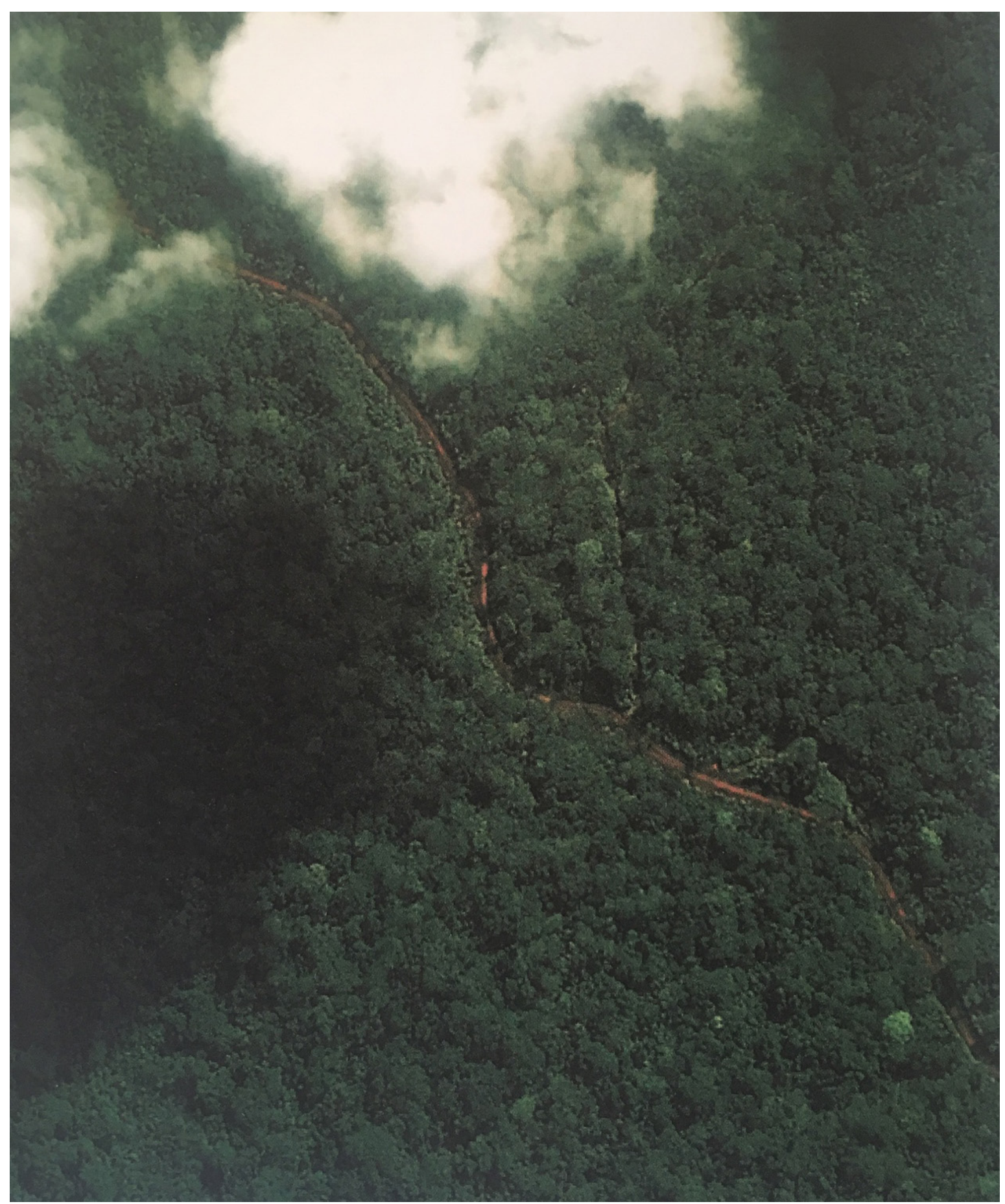

Figura 69- Verde. Floresta de planície tropical, sudeste de Camarões (zoom 2). Detalhe da estrada clandestina. Fonte: Close Up at a Distance. 
observar cada detalhe da imagem e detalhes como estes podem ser notados e nos levar a entender e/ ou questionar com mais propriedade cada elemento mapeado. Kurgan ressalta que, especialmente em áreas assim, de difícil acesso físico, essas imagens aéreas são fundamentais para uma ação mais precisa de organizações de preservação.

\section{AMARELO}

Southern Desert, southeastern Iraq, betwen Al Busayyah and An Nasiriyah.

Acquired: March 30, 2003, 07:32:10 GMT.

Center coordinates: $30^{\circ} 18^{\prime} 48.96^{\prime \prime} \mathrm{N}, 46^{\circ} 22^{\prime} 25.68^{\prime \prime} \mathrm{E}$.

QuickBird satellite, $0,61 \mathrm{~m}$ per pixel.

Para a foto amarela (Figura 70) em particular, Kurgan buscava, nos arquivos da QuickBird, por imagens que correspondessem ao momento da Operation Iraqi Freedeom em Bagdá. Ela tinha interesse em visualizar os tanques de guerra das forças armadas americanas na região; o que ela mais queria era uma imagem que documentasse a guerra. No entanto, segundo Kurgan, “[...] a DigitalGlobe de maneira informal e voluntariada 'não estava distribuindo' imagens de Bagdá nas quais tropas americanas pudessem ser vistas" (2013, p. 159). Sendo assim, Kurgan se contentou em pedir uma imagem da mesma região, mas sob outros critérios, que fossem imagens datadas de duas semanas que precediam a operação. E, para sua surpresa, ao receber a imagem, ela pode observar após um zoom (Figura 71) que havia dois helicópteros sobrevoando sob formação o deserto entre as cidades de Al Busayyah (Líbano) e An Nasiriyah (Iraque). 


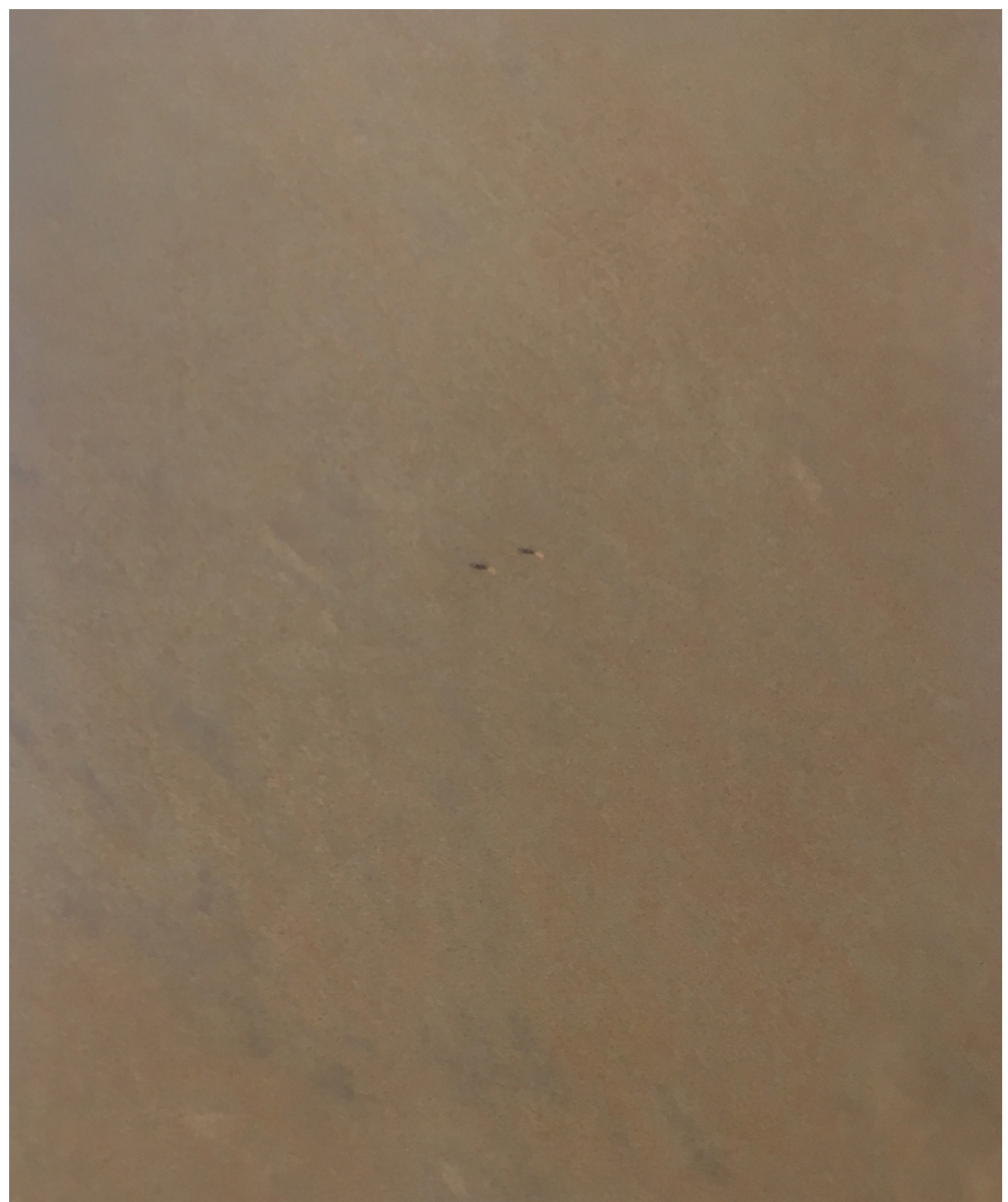

Figura 70- Amarelo. Deserto do sul, sudeste do Iraque e entre Al Busayyah e An Nasiriyah (zoom 1). Fonte: Close Up at a Distance. 


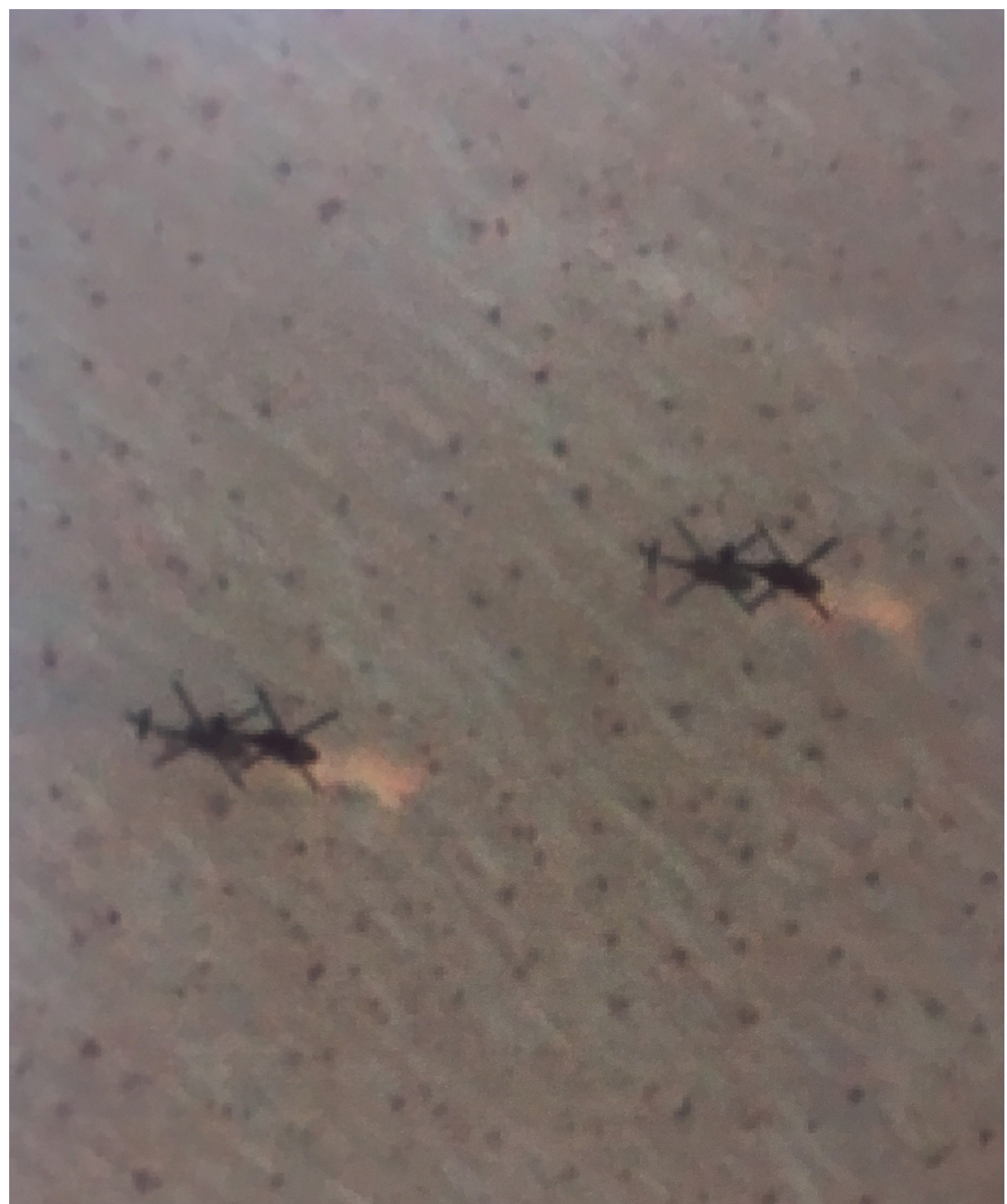

Figura 71- Amarelo. Deserto do sul, sudeste do Iraque e entre Al Busayyah e An Nasiriyah (zoom 2). Detalhe Helicópteros. Fonte: Close Up at a Distance. 
O processo de compra desta imagem só vem a confirmar os questionamentos e tensões que o trabalho aborda, colocando em xeque inclusive a transparência e acessibilidade às imagens de satélite.

Depois de entender a quantidade de informação que cada uma dessas quatro fotografias carrega em si, fica claro como Monochrome Landscapes ultrapassa uma leitura de abstração de cores e texturas. Trata-se de uma obra que evidencia como uma imagem digital de altíssima resolução encoraja naturalmente o espectador a buscar algo a mais diante dos milhares de pixels. Permite questionar e buscar, além da imagem monocromática, por aspectos geopolíticos contidos e associados no contexto de cada foto.

Como bem reforça Watson ao discorrer sobre o Monochrome Landscapes de Kurgan "A abstração gerada pelos dados, ou pelo próprio processo subsequente de tradução, pode se tornar fascinante, especialmente em seu potencial para revelar algumas das profundas e problemáticas questões em torno desta forma de visualização." ${ }^{147}$ (2013, s/n, tradução nossa). Kurgan trabalha, de maneira delicada e poética, uma questão de densidade expressiva sobre o binômio de visibilidade e invisibilidade presente nas fotos de satélite, isto é, não somente nas imagens, mas também no cruzamento de informações possíveis de serem feitas com a data, horário e local da imagem, além de entender quem fotografa, por que o faz e como se utiliza dessas imagens.

147 "Abstraction as generated by data, or the subsequent process of translation itself, could prove facinating, especially in its potential to reveal some of the deep, problematic issues around this form of viewing." (WATSON, 2013, s/n) 


\subsection{3 - PROJETO CORRESPONDÊNCIA (2013) - MANUELA COSTALIMA}

Projeto Correspondência, de Manuela Costalima, arquiteta formada pela FAU-USP ,é uma ação que articula sistemas atuais de navegação e geolocalização e formas tradicionais, hoje pouco utilizadas, de comunicação interpessoal: a artista enviou cartas para 500 pessoas que ela localizou em diversos pontos do mundo através de 'passeios' à deriva pelo Google Street View. A artista localizou essas pessoas observando atentamente as imagens durante suas derivas virtuais, e, quando encontrava uma possível relação da pessoa na foto com o endereço, estabelecia-se a escolha para realizar o contato via correspondência. A chance de acerto ou erro, encontro ou desencontro, seria um aspecto a ser confirmado com as possíveis respostas às suas cartas.

O projeto, ao final, toma a forma de uma exposição e de um livro que compilam as correspondências trocadas. Mais do que apenas estabelecer contatos com pessoas por correspondências, o projeto abriga reflexões feitas pela própria artista acerca de como se estabelece o vínculo com o outro, uma vez que nos encontramos em uma realidade hipermapeada, caracterizada por intensa mediação tecnológica. Costalima busca, com os envios das cartas, estabelecer esse contato, que se inicia a partir do mundo virtual e pretende se desdobrar em outras camadas do material.

"O mundo hiperconectado de hoje tem transformado nosso sentimento de lugar. A capacidade de comunicação imediata com qualquer lugar do planeta, a facilidade de voar a qualquer parte, acaba fazendo com que pertençamos a todos e nenhum lugar ao mesmo tempo. Deixamos de estabelecer vínculos." (COSTALIMA, 2013, p. 154)

É exatamente em uma ferramenta virtual (Google Street View), que se baseia totalmente em fotografias tiradas por um sistema automatizado atrelado a um carro, que a artista se propõe a se aventurar. Uma busca clara de trazer uma certa materialidade e significado àquelas fotos pasteurizadas pelo Google, trazer significância ao local, em outras palavras, realizar a transição de uma informação locativa virtual para a esfera material. 
Ao subverter o uso do Google Street View, que tem a finalidade primeira de permitir a localização e o (re)conhecimento de paisagens urbanas através de montagem de fotografias dos arredores de locais georreferenciados no Google maps, a artista apresenta uma nova mecânica de contato com o outro e procura colocar em xeque o 'modus operandi' da pervasão tecnológica dos dias de hoje. A artista parte de uma indagação da experiência do andar, da deriva e do perder-se, contrapondo a experiência do navegar virtualmente, no Google Street View.

Ao realizar este projeto, Costalima remete a duas experiências pessoais para estabelecer contrapontos e buscar extrair ramificações importantes de indagações iniciais que foram descritas acima, as quais a impulsionaram a executar o projeto. A primeira é uma experiência vivida de uma viagem que faz à Rússia; após vários dias de passeios turísticos padronizados, Costalima se permitiu flanar, ou seja, realizou um passeio, desprendida e entregue ao acaso pela cidade de São Petersburgo. Para ela sempre havia sido um foco de atenção e interesse conseguir vivenciar isso; havia sido necessário vencer roteiros e expectativas já preconcebidas em que um estrangeiro comum imerge, para assim se permitir perceber uma nova camada de significância de vivência da cidade.

"Estar à deriva na Rússia me fez pensar nas variadas possibilidades de vivência de um espaço e na capacidade da imaginação de nos levar a lugares mais distantes. [...] por me permitir flanar pelas ruas de São Petersburgo, descobri lugares estranhos de cuja existência eu não fazia a menor ideia. Estar ali, entregue ao acaso, me permitiu descobrir pela própria experiência uma Rússia pós-moderna, uma resposta dos tempos de hoje àquele universo tão presente no meu imaginário.” (COSTALIMA, 2015, p. 127)

A segunda experiência que Costalima descreve é o seu 'caminhar' à deriva no mundo virtual, precisamente, pelo Google Street View. Ela descreve as inúmeras horas de navegação no Google Street View, passeio que, segundo ela, é uma prática deambulatória impossível de escapar dada a quantidade de possibilidades que a internet oferece. Ela inclusive ilustra esse fato citando como exemplo um curta-metragem chamada Noah, que se passa em tempo real 
(17 minutos) e mostra a tela do computador navegado por uma adolescente. Mesmo que a artista não tenha se valido dos variados aplicativos utilizados pelo protagonista do Curta, ela passou imersa no mundo do Google Street View observando atentamente as paisagens, procurando pessoas de interesse para tentar estabelecer contato e igualmente bombardeada pela densidade informacional do mundo virtual.

"De link em link, de aba em aba, passo por tanta informação que me esqueço de quase tudo logo depois. São tantas imagens e possibilidades circulando pelo mundo virtual que acabo atônita [...] Estar imerso nesse mundo das imagens tem realmente esse efeito narcótico: ficamos anestesiados como defesa a esse bombardeio de imagens e informações sofridas a cada instante." (COSTALIMA, 2013, p. 162)

Durante esse processo de deriva no Google Street View, Costalima começou a se questionar o quão imersa ela estava no mundo virtual e se havia se perdido nele; no entanto, quando chegou no momento de organizar os endereços, imprimir as fotos e envelopar as cartas, o projeto, para ela, começou a se adentrar ao mundo material.

"No correio, me vinha a certeza de que aquilo não era devaneio. Os envelopes todos passando pela máquina seladora, sendo encaminhados aos entregadores, me faziam crer que ao menos aquilo era real. Não era mais uma fantasia minha; os envelopes do projeto já não me pertenciam mais. Encontravam-se agora em meio a pacotes, cartas comerciais e algumas poucas correspondências pessoais." (COSTALIMA, 2013, p. 12)

Foram, no total, 500 cartas enviadas, dentre elas 50 cartas que retornaram sem atingir o destinatário ('domicílio abandonado', mudou-se' ou não existe correspondente'), muitas que nunca retornaram ou obtiveram resposta, mas 8 cartas foram respondidas (Figura 72). Com as respondidas aconteceram, segundo a autora, uma importante transformação: "pela partilha de suas histórias, por meio de seus relatos, os não-lugares das imagens virtuais ganhavam novo significado. Eles se tornavam lugar." (COSTALIMA, 2013, p. 14) 
Um caso relatado pela artista é o de David Guss - um destinatário de Sommerville Massachusetts, que recebeu a carta de Manuela juntamente com a imagem que ela retirou do Google Street View (Figura 73). Na carta de resposta, Guss esclarece à artista que a pessoa de azul da foto era o carteiro local e explica brevemente sobre as frondosas árvores que também se encontram retratadas na imagem enviada.

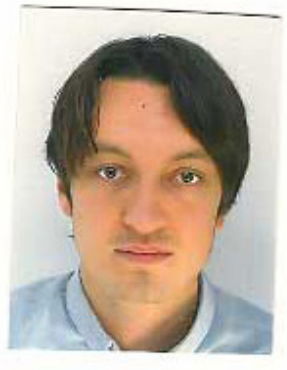

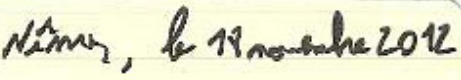

Chen Manuela,

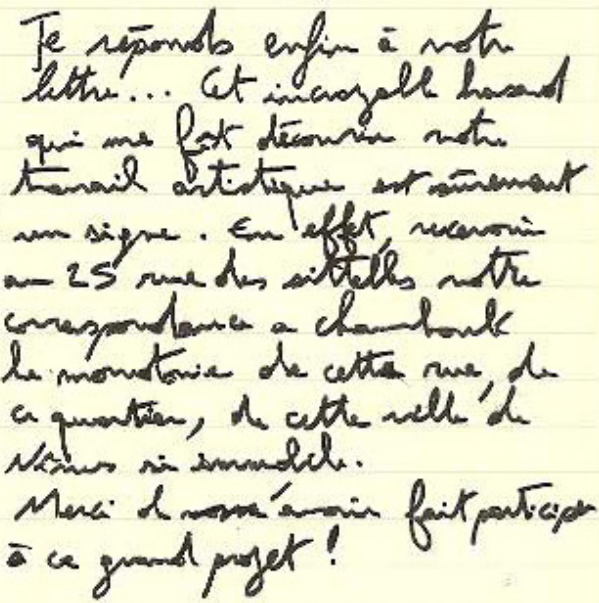

Anec Kut

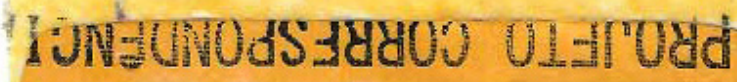

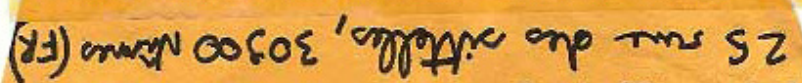

no!y punyry

\section{IR * $* 0,49$ EUR}

LETTRE P N NITAREENTERNATIONALE RECOMMANDEE RI AR

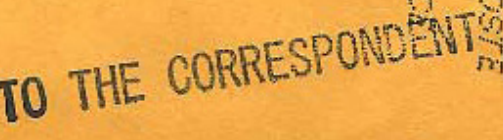

Thuela costaima rua iraquitä, 69

jd. pautista

são pauto SP

$01432-940$

BRASLL

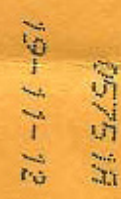

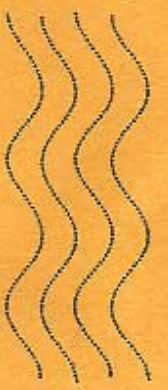

Figura 72- Um dos envelopes que retornaram com resposta. Fonte: manuelacostalima.com. 
Ainda em sua carta-resposta, Guss conta um pouco sobre a construção da casa e a história do bairro, que havia sido um local primeiramente ocupado por trabalhadores/ prestadores de serviços, e hoje a redondeza é ocupada majoritariamente por arquitetos, artistas, escritores e professores universitários (muitos de Harvard e Tufts). Ele conta também as diferentes etnias que convivem por lá e ressalta a grande comunidade de brasileiros que a cidade possui.
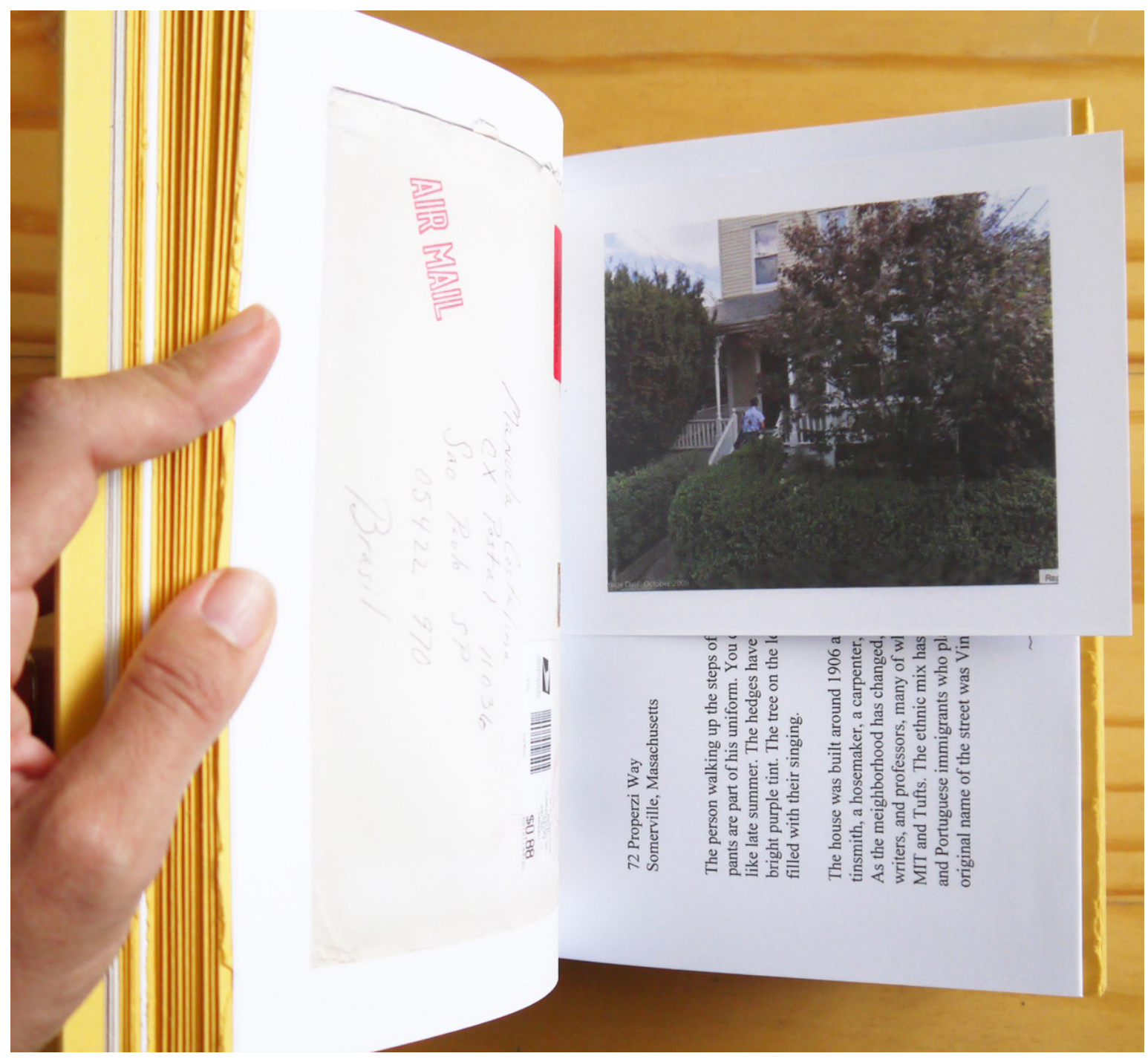

Figura 73- Foto do livro 'projeto correspondência' de Manuela Costalima. Aberta na parte que mostra a carta respondida pelo correspondente David Guss e com a foto do Google streetview que a autora encontrou em meio sua deriva e utilizou para estabelecer vínculo com o correspondente. Fonte: manuelacostalima.com. 
Esse retorno foi um contato concretizado e vitorioso para a artista. Ela não só estabeleceu um vínculo com alguém, mas aquela foto passou a significar um lugar com história e vida. E o grande número de cartas que retornaram sem alcançar o correspondente (Figura 74), Costalima não assumiu como motivo de frustração; eram antes índices de erros/falhas esperados em meio às transições do mundo virtual ao material. Ainda que estes envelopes não tivessem alcançado o correspondente, o interesse já existia no objeto, o envelope viajante.

“Os envelopes que voltavam para mim estiveram em lugares distantes, passaram pelas mãos de carteiros e foram transformados pela experiência do caminho." (COSTALIMA, 2013, p. 13)

O foco da artista passa a se direcionar então aos envelopes que retornaram, com resposta ou não. $\mathrm{O}$ interesse dela estava na transformação que todo o processo gerou. A artista faz ainda

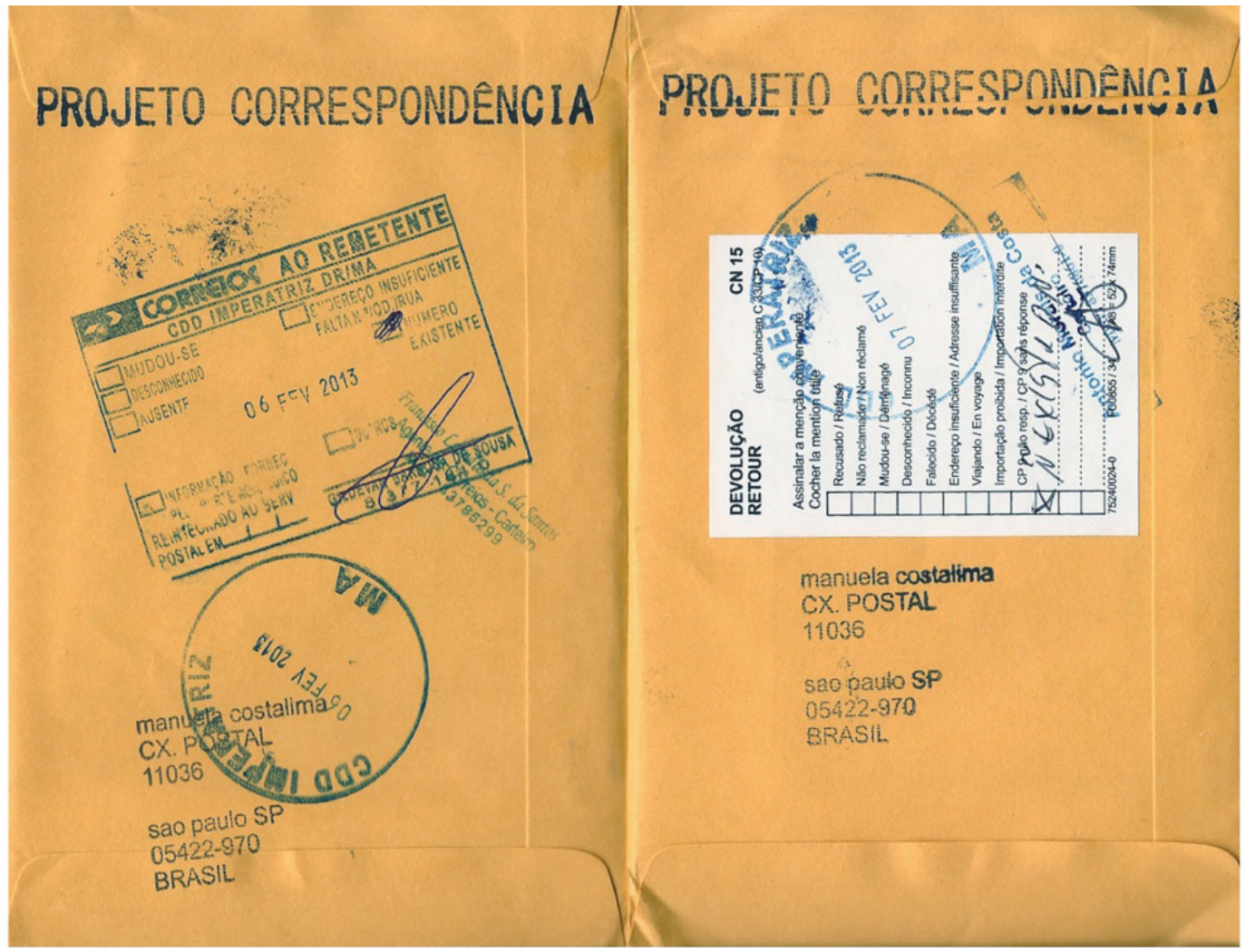

Figura 74- Envelope que retornou sem resposta. Fonte: manuelacostalima.com. 
uma interessante comparação com o filme 'Blow Up: depois daquele beijo', de Michelangelo Antonioni, em que o protagonista só descobre algo que aconteceu no mundo real, que não estava em seu foco de atenção, após revelar a foto, editá-la e ampliá-la. Para Costalima, esse processo de descoberta do mundo real através das fotos do Google Street View é como um processo que descreve de 'refotografia': um adentramento no virtual para um tipo de compreensão e primeiro contato com o material.

O projeto correspondência traz um profundo questionamento do que é a experiência do lugar, de como a esfera virtual pasteuriza a significância e a experiência da esfera real. Indaga a imprecisão quando há um trâmite entre as duas esferas. A hiperconexão nos bombardeia com alta carga informacional, no entanto, nos venda de tantas outras que, por interesse ou desinteresse de terceiros, não recebem a visibilidade possível ou nos anestesiam de informações igualmente importantes que só podem ser adquiridas da experiência vivida e dos vínculos possíveis ao longo do caminho. 


\subsection{4 - CANAL MOTOBOY (2007-2015) - ANTONI ABAD}

O projeto Canal Motoboy foi realizado no Brasil como uma parte de um projeto maior chamado 'Megafone.net'. O artista catalão Antoni Abad lançou o canal de internet 'Megafone. net' (Figura 75) com a intenção de dar voz e visibilidade a grupos que normalmente são invisibilizados/calados pela sociedade.

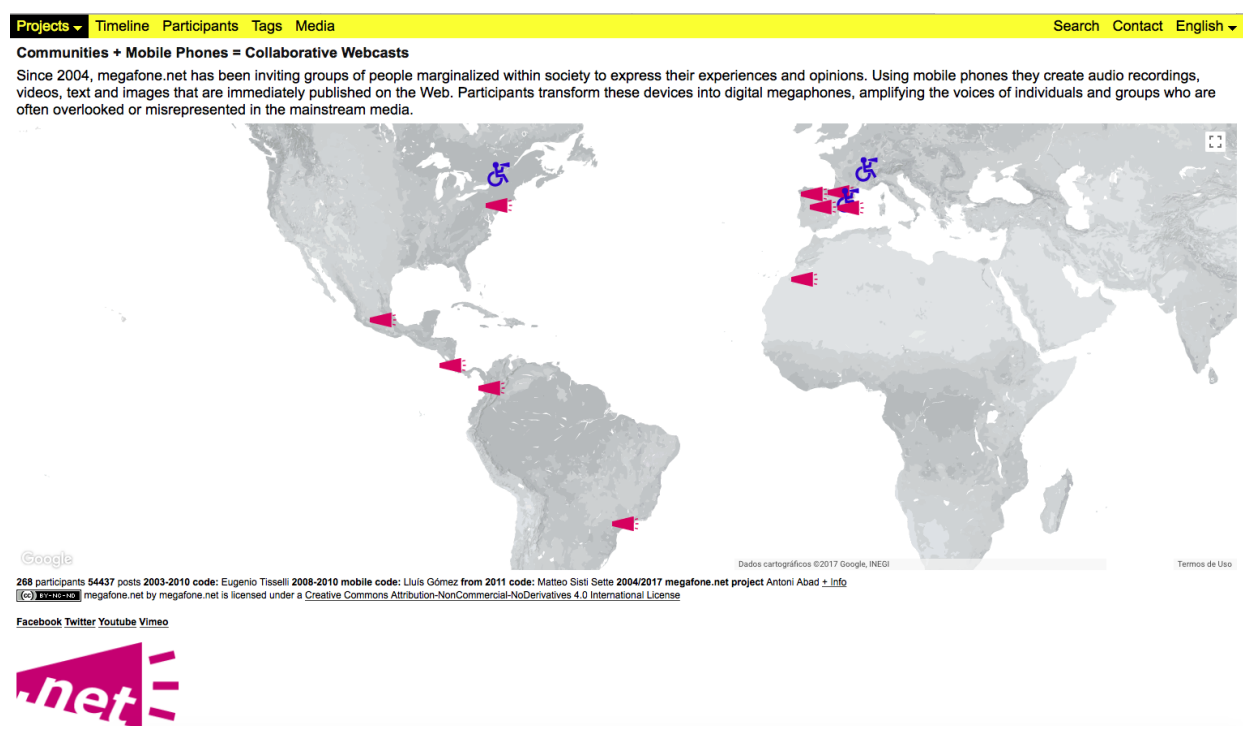

Figura 75- Interface do Megafone.net Fonte: megafone.net

O projeto Megafone.net atuou em diversas cidades do mundo. Começou com uma versão na cidade do México com um grupo de taxistas; possui uma versão em Madrid na qual o artista focou em um grupo de prostitutas, a versão de Barcelona com grupo de deficientes visuais e, dentre tantas outras, a versão brasileira (projeto Canal Motoboy), que teve como foco os motoboys da cidade de São Paulo.

Em cada cidade, o artista recorreu a maneiras diversas para montar os grupos de colaboradores. Para reunir os taxistas da Cidade do México, por exemplo, Abad recorreu a anúncios em jornais locais e a um programa de rádio. Já para montar o grupo de motoboys em São Paulo, contou com a indicação de um motoboy conhecido, Ronaldo, que se incumbiu de indicar os demais motoboys participantes, além de ter se tornado porta-voz do projeto e ter sido o que mais produziu imagens no projeto Megafone.net. 
O projeto Canal Motoboy (Figura 76) teve seu início no ano de 2007, apesar da ideia ter surgido no ano de 2004. A demora do seu início foi a dificuldade de encontrar financiamento para um projeto de artes que envolvia Motoboys, o que só confirmava a marginalização da classe, exatamente o que interessava Abad.
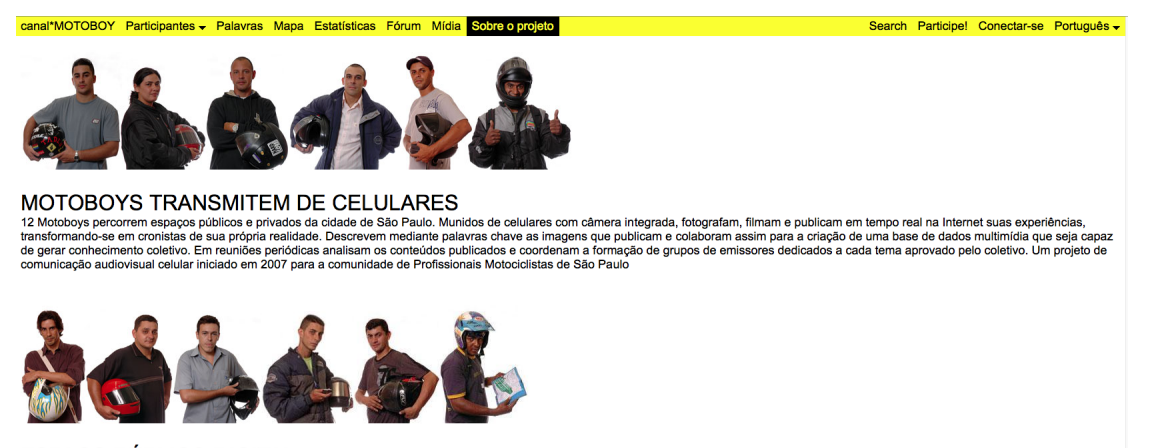

ESPAÇO PÚBLICO DIGITAL

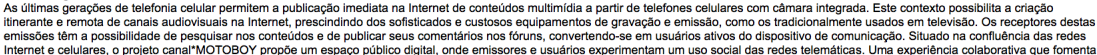

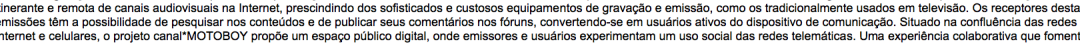

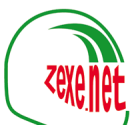

Figura 76- Página do 'Canal Motoboy’ no site Megafone.net. Apresentação dos motoboys colaboradores do projeto. Fonte: Megafone.net

Abad forneceu a 17 motoboys celulares com câmera para que registrassem sua rotina nas ruas, e essas imagens e vídeos alimentaram em tempo real o mapa no site 'Megafone.net', que possui acesso livre para quem quiser consultar. Vale notar que o início do projeto (2007) é paralelo ao começo da difusão de uso de mapas colaborativos e mídias locativas no país de maneira mais expressiva, especialmente com a popularização dos celulares/smartphones.

A intenção principal do artista com esses uploads de registro do cotidiano nas ruas de São Paulo foi dar voz e visibilidade ao grupo. E, desta forma, pretendia atenuar a imagem agressiva e rebelde que a categoria possui diante da sociedade paulista em geral, além de com isso apresentar e identificar problemas vividos na cidade de São Paulo.

"Os motoboys poderiam, dessa maneira, transformar-se em cronistas de sua própria realidade, autorrepresentando-se e corrigindo a imagem distorcida que os meios de comunicação projetam deles." (ABAD, 2009, p. 12) 
Abad expressa que percebeu como a marginalização que a categoria sofre é fortemente relacionada ao que a mídia veicula em notícias e manchetes quando o assunto envolve os motoboys. Como ele mesmo afirma: "Os motoboys aparecem nos meios de comunicação paulistas quase sempre em histórias truculentas que potencializam os piores preconceitos na percepção social da categoria.” (2009, p. 11). No entanto, o artista traz um contraponto importante, ressalta que, apesar dessa imagem negativa que é constantemente associada à categoria, esquece-se de ressaltar características positivas e muito particulares da mesma.

"[...] poucas vezes se enfatiza o lado mais positivo desse coletivo, que demonstra um sentimento de solidariedade muito particular, uma consciência corporativa que antepõe o socorro a um companheiro acidentado à urgência de uma entrega." (ABAD, 2009, p. 11)

Além dos registros realizados individualmente por cada motoqueiro, também eram realizadas reuniões periódicas entre o grupo e o artista. Encontros que discutiam as repercussões recentes de alguns registros e pautas futuras. $\mathrm{O}$ formato dessas reuniões contava com a presença do artista; no entanto, ele não opinava e nem dirigia o encontro. $\mathrm{O}$ fundamental era permitir que a própria comunidade encaminhasse suas discussões e tomasse suas próprias decisões. Como fruto dessas reuniões periódicas, o projeto lançou um livro no ano de 2009, chamado 'Coletivo Canal*MOTOBOY' ${ }^{148}$. Nele vários motociclistas expressam suas frustrações e expectativas pelo fato de pertencerrm a essa categoria marginalizada. A versão eletrônica do livro é disponibilizada gratuitamente na internet e procura transmitir importantes pontos de discussões que surgiram ao longo das várias reuniões periódicas do projeto.

Dos 17 que compuseram o grupo, apenas 2 eram mulheres. Em uma reportagem da Revista Zum, escrita por Daigo Oliva, afirma-se que a proporção é coerente com a realidade da categoria na cidade de São Paulo, e ainda reforça que "segundo o Detran, apenas 9,49\% das 1.111.998 carteiras habilitadas para dirigir motos pertencem a motoristas do sexo feminino" (2016, s/n). Nesta reportagem, afirma-se que, mesmo com esta disparidade de gêneros, os

148 Livro Coletivo canal• MOTOBOY- Organizado por Eliezer Muniz dos Santos (Neka) ex-motoboy, emissor e colaborador do Projeto Canal*MOTOBOY. 
temas de postagens no projeto não diferiam muito.

O projeto durou de 2007 a 2015, tempo significativo para colher respostas e resultados do mapa colaborativo. Os registros realizados ao longo desse período foram bastante numerosos, tinham caráter de denúncia, alerta ou até mesmo de cenas de tranquilidade que encontravam na rotina pelas ruas. Grande parte do conteúdo postado pelos motoboys era relacionado à cidade e ao trânsito: acidentes, engarrafamentos, túneis, motopeças, infrações no trânsito, buracos na rua, cães bravos, murais grafitados, entre outros (Figuras 77 e 78).

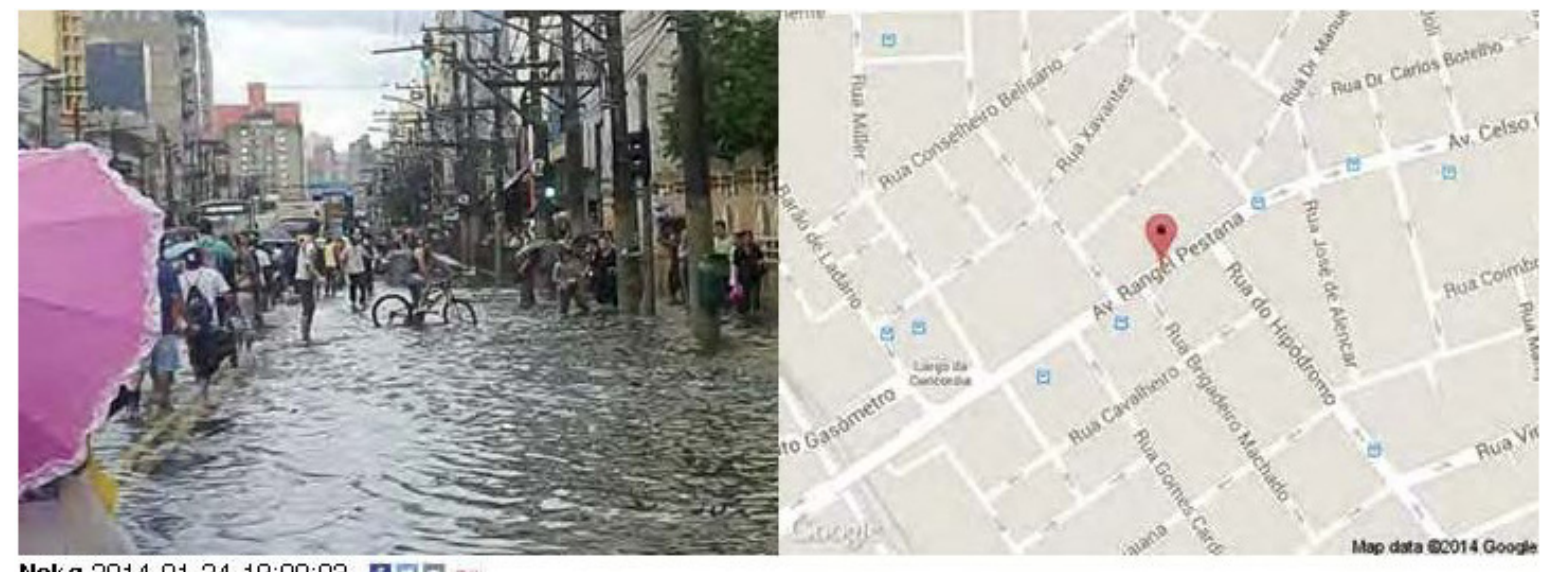

Nek a 2014-01-24 19:00:03 frole or

\#tr ansito \#chuvas \#dia a dia \#enchen te \#Mu uca

Foto en viada pela noss a colabor adora Fablol a Bin as

Figura 77- Registro de inundação na Av. Rangel Pestana. Fonte: Megafone.net

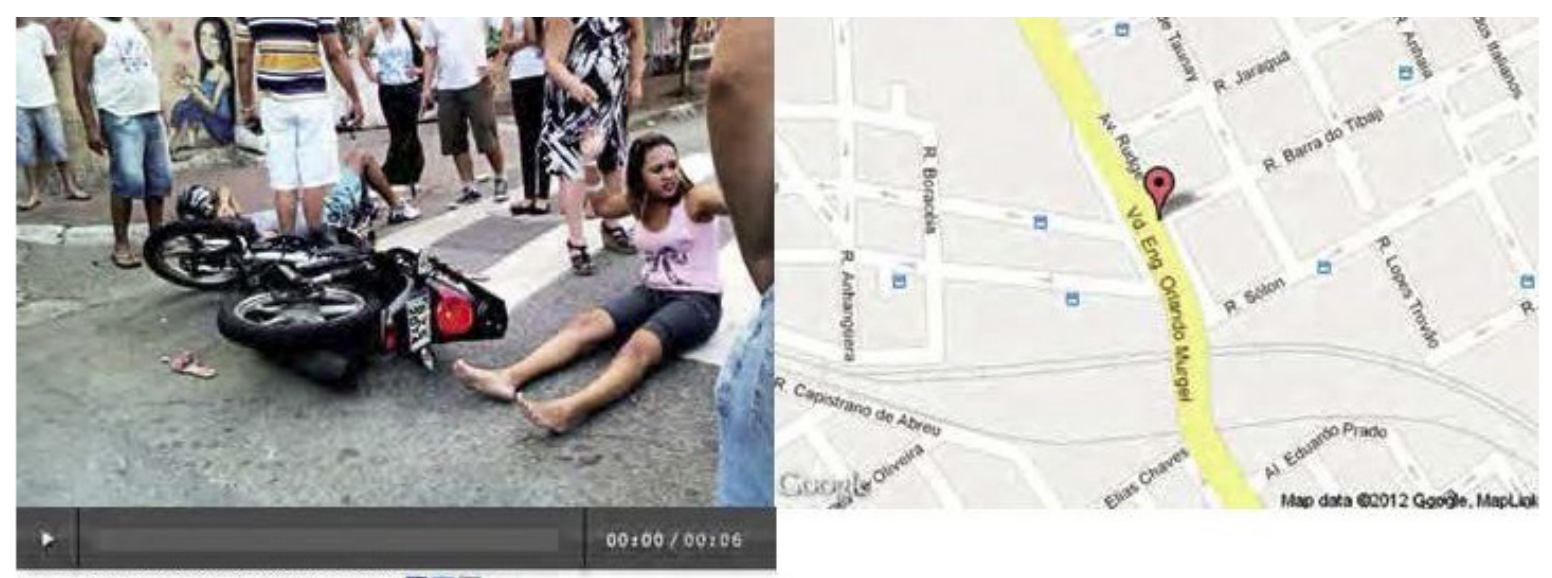

Ronaldo 2012-10-08 21:38:09 1000 -

\#acidentes

Figura 78- Vídeo registrando um acidente envolvendo um motoqueiro. Fonte: Megafone.net 


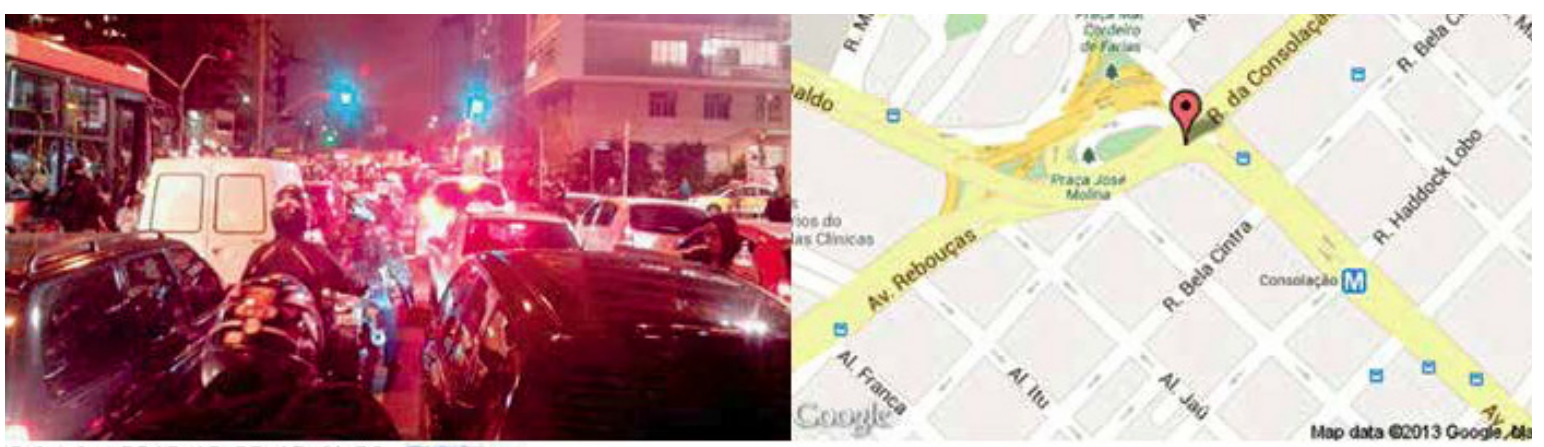

Crispim 2013-10-20 19:41:36 미뭉

\#transi to \#manifestaçăo

Figura 79- Registro em foto de um trânsito parado devido a uma manifestação da Rua da Consolação. Fonte: Megafone.net

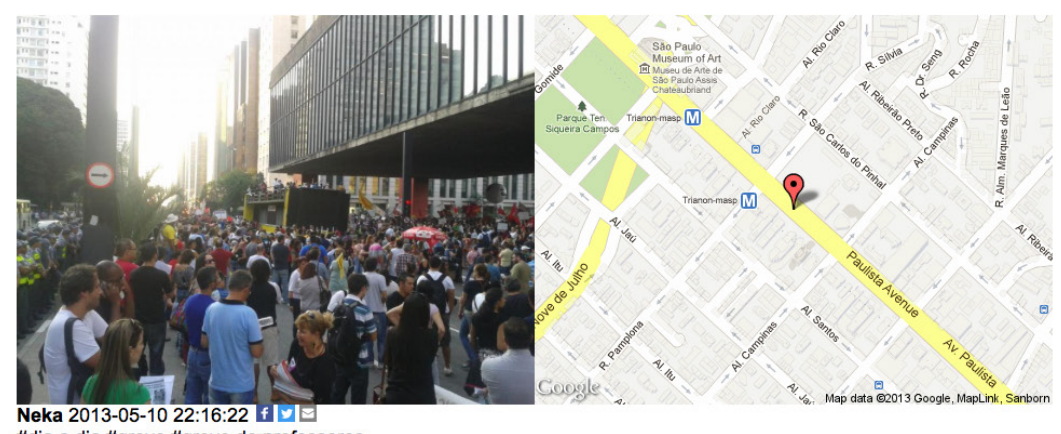

\#dia a dia \#greve \#greve de professores

Indignado. A sociedade e os professores viram nesta sexta feita a mais lamentável situação: a categoria dos professores abandonada, ou seja, a educação de nossos filhos tratada com o maior desprezo já visto por aqueles que deveriam guarda-la e defende-la. O governo venceu. A Apeoesp venceu (resolveu seu próprio imblóglio). A educação e a sociedade perdeu. lamentável..

Figura 80- Registro da manifestação de greve de professores que ocorreu em 2013 na Av. Paulista. Fonte: Megafone.net

Ainda nas postagens da rotina diária das ruas, por vezes testemunharam-se acontecimentos sociais e políticos marcantes na cidade. No entanto, o entendimento e a postura diante do acontecimento variam conforme o engajamento social e político do próprio motoboy que posta o registro. Para ilustrar melhor, basta observar a Figura 79, em que o motoboy Crispim posta a manifestação com a qual se deparou na movimentada Rua da Consolação. Essas manifestações de 2013 foram de importância significativa no espectro político brasileiro, no entanto, Crispim vincula sua imagem à hashtag "trânsito" (Figura 79). Fica evidente que, para ele, o ponto de atenção está em como o evento interfere no trânsito e como impossibilita seu trabalho. Enquanto a postagem de Neka (figura 80), que também se depara com uma 
manifestação de professores, ao contrário de Crispim, dedica-se juntamente a expressar seu apoio à manifestação e seu descontentamento com as medidas governamentais relacionadas à educação.

Um outro aspecto apresentado nas postagens, não muito frequente, porém presente, são as postagens relacionadas à vida pessoal e social dos motoboys, desde momentos familiares até cultos religiosos (Figuras 81 e 82).

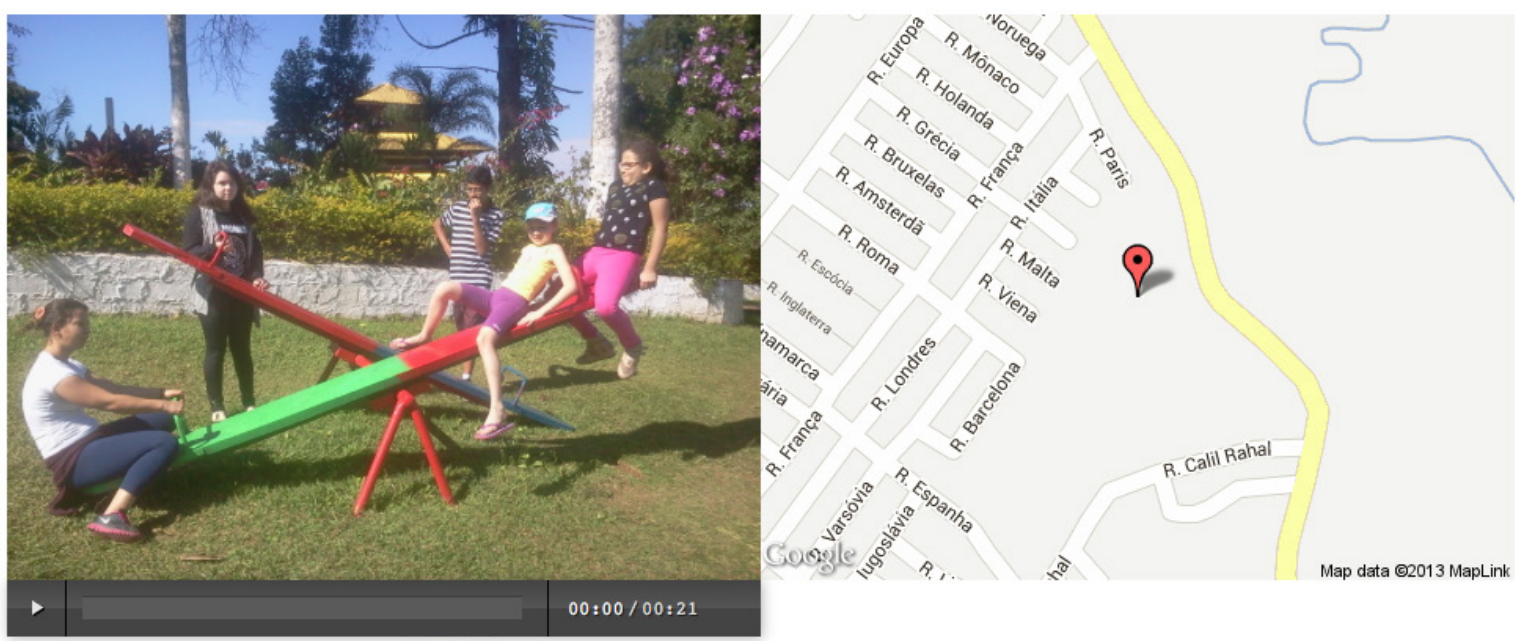

Ronaldo 2013-07-20 11:10:22 f \#familia

G+

Figura 81 - Postagem de vivência familiar do motoboy Ronaldo. Fonte: Megafone.net

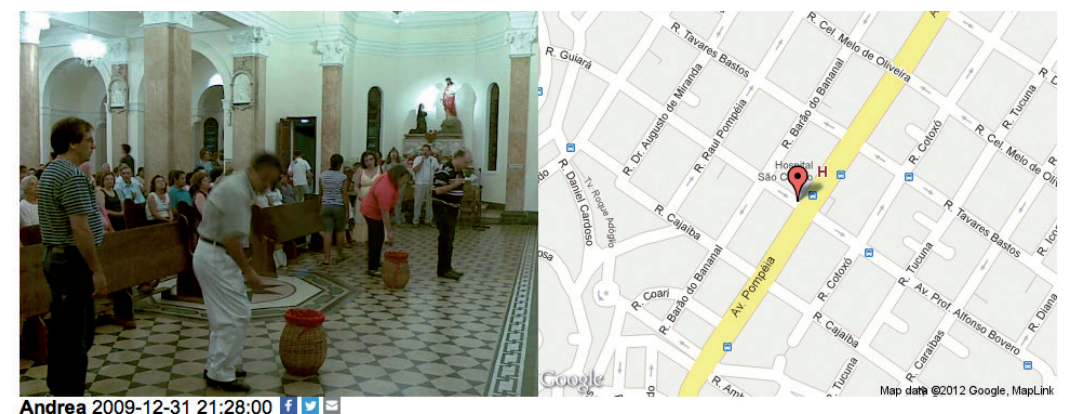

Andrea 2009-12-31 21:28:00 f

\#igrejas \#missa

Toda a comunidade reunida pra louvar e agradecer ao ano que passou e pedir a Deus que abençõe também este próximo ano que chega.Obrigado por todas as bençãos que recebemos em 2009.

Figura 82- Postagem de culto religioso da motoboy Andrea. Fonte: Megafone.net 
Além dos registros visuais dos celulares, os participantes do Canal Motoboy também forneciam palavras-chave (Hashtags). Essas palavras formavam uma espécie de mural de catalogação, e cada projeto de cada cidade possuía suas palavras de destaque, que se tornavam mais utilizadas. As palavras-chave de destaque do Canal Motoboy foram, por exemplo, Corredores, Acidentes e Família.

O projeto Canal Motoboy se mostrou bastante eficiente, pois, além da repercussão online, alcançou a televisão brasileira, foi exposto em inúmeros museus e centros culturais da cidade (MASP, Centro Cultural São Paulo, Pinacoteca), assim como em grandes eventos de tecnologia como a Campus Party. Hoje, muitos desses 17 motoboys colaboradores estão envolvidos em outras atividades e não mais atuam como motoboys, mas muitos continuam ativos em outras mídias sociais, depois que entenderam o alcance que suas vozes podem ter em ferramentas desse tipo.

Em uma entrevista realizada em setembro de 2011 para o site Cartografias on-line, Elizer Muniz dos Santos ${ }^{149}$ respondeu à entrevista como porta-voz do projeto, aqui no Brasil. Nessa entrevista, foram abordadas questões da repercussão do projeto, que já completava seu quinto ano. Segundo Santos, como repercussão do projeto, houve o lançamento do livro "Coletivo Canal* MOTOBOY- O Nascimento de uma categoria", a realização de palestras e a mobilização da categoria dos motoboys.

Santos detalha também, na mesma entrevista, que a plataforma tecnológica foi desenvolvida com uma parceria com o programador Eugenio Tisseli. E ainda afirmou que o uso de mapas nesse projeto foi importante para apresentação/visualização de dados, localizar e pensar estratégias políticas. $\mathrm{O}$ entrevistador lhe indaga se ele classificaria a plataforma como uma cartografia colaborativa e ele esclarece que, até certo ponto, sim, mas entende que esse mapa gerado pelo projeto tem um sentido mais unidirecional, ou seja, o intuito era que cidadãos da cidade consumissem as informações do mapa, e não apenas os próprios motoboys.

149 Eliezer Muniz dos Santos (Neka) ex-motoboy, emissor e colaborador do Projeto Canal*MOTOBOY. Também organizador do livro Coletivo canal• MOTOBOY-Nascimento de uma categoria. 
"Dependendo da necessidade sim, mas podemos chamar de rede social telemática, ou simplesmente, 'cartografia' remete as cartas e mapas que prescindem de uma colaboração interpretativa, no caso, os motoboys já tem um mapa na cabeça, não precisa plantar outro em cima.” (SANTOS, $2011, \mathrm{~s} / \mathrm{n})$

\subsection{5 - OS QUATRO PROJETOS, ENTRE OS MAPAS E AS TRAJETÓRIAS}

Para o presente trabalho, optou-se por quatro projetos a fim de que, além de se dedicar a uma leitura minuciosa de cada um dos projetos individualmente, também proporcionar com uma leitura/análise conjunta dos quatro, um aprofundamento e articulação de conceitos e perguntas dessa dissertação.

É pertinente considerar que, em um trabalho que pretende refletir sobre as (contra)cartografias, observar projetos contracartográficos realizados por artistas é fundamental. Artistas trazem, em seus mapas, uma preocupação estética particular com o modo de representar e pensar cartografias e localização. O campo da arte contribui fortemente com as maneiras de revisitar conceitos e padrões já estabelecidos historicamente, permite aproximações poéticas e inesperadas, que, além de resultarem em novas representações, não deixam de lado a motivação de indagar questões políticas, econômicas, sociais e de poder; não deixam, portanto, de serem contracartografias.

Para iniciarmos essa leitura conjunta dessas obras, é necessário resgatar o conceito apresentado por Tuters e Varnelis já mencionado no início deste capítulo. Eles, ao tratarem especificamente do uso de mídias locativas nas artes visuais, distinguem duas modalidades de uso da tecnologia geolocativa pelas práticas cartográficas na arte, uma sendo anotativa espacial e a outra, de traçados, fenomenológica. Projetos utilizando a modalidade anotativa espacial são mapas produzidos digital e colaborativamente. São dinamicamente formatados, de maneira que o território é experienciado por meio da navegação mediada pela tela de 
um dispositivo. Normalmente, utilizam-se de marcações digitais $\left(\operatorname{geotag}^{150}\right)$ associadas a alguma outra informação definida pelo artista, buscando modificar ou, ao menos, influenciar o meio. Já a outra modalidade, a fenomenológica, trata-se de uma aproximação a partir da experiência física do sujeito. Em outras palavras, quando a cartografia acontece a partir do percurso de uma pessoa ou grupo, quando o movimento e ação do sujeito no mundo estão sendo capturados e representados.

Karen O'Rouke, em seu livro 'Walking and Mapping - artists as cartographers', também cita as modalidades apontadas por Tuters e Varnelis. E relembra que artistas, antes das mídias locativas, já lidavam com questões similares. O’Rouke resgata como esse modelo parece ter uma ligação direta com trabalhos como os de Richard Long; no entanto, com a ressalva de que agora são acionados com o uso de GPSs e outras mídias locativas.

"Seguindo os passos de Richard Long, vários artistas levaram a se localizar enquanto se moviam pelo mundo, mas agora usam o GPS como meio de desenho. Os dispositivos GPS podem ser feitos para produzir esboços em papel, na tela, em outras superfícies. Os artistas usam seus próprios corpos e outros para fazer trilhas que muitas vezes são destinadas a durar "151 (O’ROUKE, 2013, p. 132)

Essa categorização realizada pelos autores orienta uma maneira de ler e entender processos mediados utilizados pelos artistas, no entanto, essa divisão entre uma e outra modalidade nem sempre se traduz em trabalhos artísticos de maneira tão clara. Como já foi citado, Meridians (Obra de Jeremy Wood) é um exemplo que pode ser imediatamente associado à modalidade fenomenológica. A obra é precisamente gerada a partir do percurso do próprio artista, que registra em GPS seu particular trajeto; no entanto, lida também com demarcações em fotos satélites e apresenta uma vista aérea (sujeito não inserido). Outra obra, das abordadas neste

150 Geotag: Podendo ser traduzido como Geo-marca. Trata-se do processo de adicionar metadados de georreferencias em alguma plataforma digital (sites, mapas digitais, vídeos, entre outros).

151 "Following in Richard Long's footsteps, a number of artists have taken to locating themselves as they move around the world, but now they use GPS as a drawing médium. GPS devices can be made to produce sketches on paper, on screen, or on other surfaces. The artists use their own and others' bodies to make trails that often are intended to last."(O'ROUKE;2013:132) 
capítulo, que também possui essas modalidades (anotativa e fenomenológica) tensionadas é o Canal Motoboy. Apesar de possuir uma aproximação estética bem diferente da utilizada por Jeremy Wood, o Canal Motoboy também surge de experiências vividas em tempo real pelos motoboys, e são as informações audiovisuais dessas vivências diretas nas ruas de São Paulo que formatam o mapa. Ambas as obras, partem de uma relação bottom-up, ou melhor, do movimento cartográfico que se faz a partir do sujeito. No entanto, mesmo apresentando claramente esse caráter fenomenológico, há também um aspecto anotativo nos mesmos projetos. Isso ocorre quando, uma vez demarcada a experiência vivida no seu percurso, essa demarcação também acontece em um mapa de base Google (No quadro direito da Figura 83) ou em fotografias de satélite.

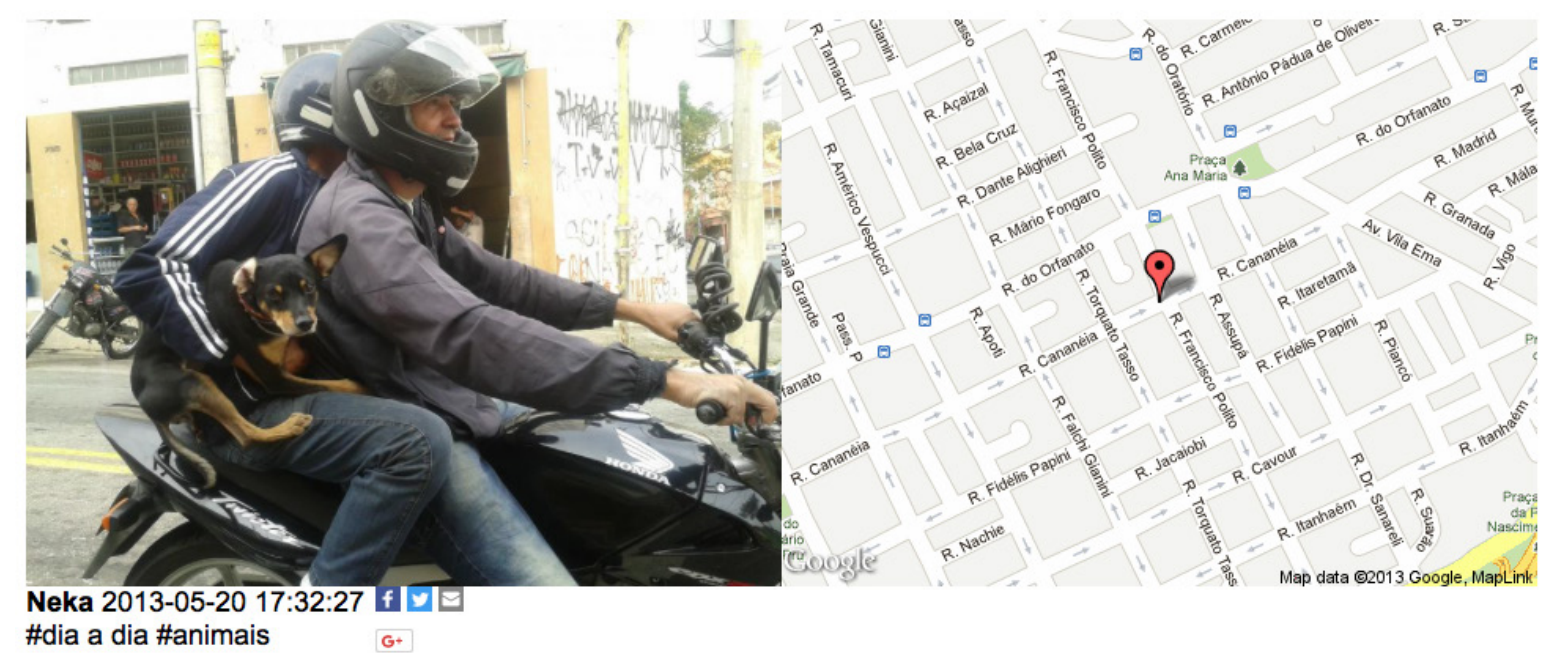

Figura 83- Resultado das postagens inseridas pelos motoboys. À esquerda fica o registro visual e à direita o mapa com a marcação do local em que o registro foi realizado. Fonte: Megafone.net.

Por sua vez, em termos dessas modalidades classificadas por Tuters e Varnelis, o projeto Monochrome Landscapes (de Laura Kurgan) é um exemplo claro de caráter anotativo espacial. Um trabalho que parte de fotografias de satélite de coordenadas GPS específicas; a artista as utiliza para revelar as várias camadas informacionais que possuem. Já o Projeto correspondência (de Manuela Costalima), em que a artista se utiliza do Google Street View para realizar sua deriva, poderia ser caracterizado como um projeto que retoma o mapeamento 
fenomenológico. Apesar de sua deriva e suas trajetórias ocorrerem no âmbito virtual, ela cria um percurso próprio elencando imagens específicas para posteriormente, estabelecer contato por meio material.

Uma vez observadas as obras à luz da divisão proposta por Tuters e Varnelis, torna-se necessário retomar um outro ponto, relacionado ao que foi desenvolvido na primeira parte do primeiro capítulo. De forma recorrente ao longo da história, foram utilizadas duas maneiras de representar localizações, mapas e trajetórias. O mapa como uma visão em que o sujeito não se insere na representação e a trajetória que é uma representação em primeira pessoa - um sujeito totalmente inserido na representação. Essas duas maneiras de apresentação continuam a permear as diversas mídias locativas utilizadas nesses quatro projetos elencados neste trabalho. Inclusive algumas delas trazem uma combinação das duas representações, como a Jeremy Wood, que sobrepõe o registro do seu percurso (trajetória) em uma imagem feita por fotos satélite (mapa). O mesmo podemos dizer do trabalho Canal Motoboy, em que os registros realizados pelos motoboys são registros pessoais - do ponto de vista deles inseridos em um mapa geral da cidade.

É possível notar como, nessa amostra de quatro trabalhos, os artistas articulam e desenvolvem seus anseios e indagações sobre o localizar-se, a espacialização de informações e as experiências contemporâneas mediadas por dispositivos de geolocalização. Kurgan enfatiza o binômio de visibilidade e invisibilidade presente nos mapas, traz à tona a falsa percepção de neutralidade que os mapas possuem e que há infinitas perguntas a se fazer frente a qualquer mapa ou a uma pequena imagem de satélite.

"[...] bem como os conjuntos de dados e as tecnologias usadas para traçálos - não são neutros"'152 (KURGAN, 2013, p. 17, tradução nossa)

Jeremy Wood, por sua vez, em Meridians traz indagações similares, ao comparar dois padrões de meridianos (de épocas e base de cálculos distintos). Evidenciando que não são coincidentes e que, apesar de padronizações científicas e matemáticas que trazem o selo 152 "[...] as well as the data sets and the Technologies used to chart them- are not neutral" (KURGAN, 2013,p.17) 
de garantia dos mapas, aponta que não há precisão total - são simplesmente convenções que são aceitas como verdades. Kurgan traz, em seu painel azul, exatamente esta reflexão, quando tenta mostrar a foto das coordenadas 0,0 e explica que, para convencionar esse ponto, justifica-se a criação de uma ilha imaginária de $1 \mathrm{~m}^{2}$. Ambos artistas evidenciam essa falha de geocódigo que existe ao representar onde se está.

Manuela Costalima já não se ocupa da questão de falhas de precisão na representação da localização, mas focaliza a transição/tradução do virtual para o material, explorando ambas realidades e extraindo experiências distintas. Ela busca, nessa transição de realidades, uma transformação de significância, o que chama de "não-lugar" se tornar um "lugar", até o surgimento de vínculo real a partir do contato fictício e inexistente de uma imagem do Google Street View.

Em um sentido inverso ao trabalho de Manuela Costalima, o projeto Canal Motoboy vai atribuindo vínculos e experiências particulares de pessoas em um mapa virtual. A partir com as experiências rotineiras, visibiliza um universo inesperado, pois conjuntamente das vivências urbanas de trânsitos já previstos, esses personagens expõem seu cotidiano social desvelando aspectos sociais normalmente despercebidos.

Percebe-se que essas contracartografias de artistas lidam com aspectos mais profundos e amplos em se tratando do universo da cartografia e das georreferências. Possuem um grau de sensibilidade que se traduz, na maioria das vezes, em uma estética mais poética do que a de mapas comuns. O único projeto dos quatro aqui abordados, que traz em termos de linguagem e representação algo mais próximo aos mapas comuns, inclusive muito próximo aos mapas colaborativos ativistas que vimos, é o Canal Motoboy. No entanto, diferentemente dos demais projetos aqui mostrados, é um projeto que não é de execução direta do artista. No caso, por se tratar de um projeto executado por motoboys, o foco estava mais no conteúdo, nas indagações e nas revelações que se desdobrariam a partir dos milhares de registros visuais postados por eles.

Por fim, estes quatro projetos contracartográficos deslocam as mídias locativas do seu 
uso e senso comuns. Atuando nos interstícios de suas lógicas de operação, esses artistas abrem outras possibilidades de ação: Wood utiliza o GPS para 'escrever', Kurgan navega da abstração cromática ao sentido geopolítico por meio de zooms em fotos de satélite de altíssima resolução, Costalima estabelece contato com o outro através do Google Street View, e Abad cria, através de vários smartphones em posse de motoboys, uma 'janela' no universo de uma categoria normalmente rejeitada e invisibilizada. Tais possibilidades indicam um campo fértil a ser explorado pelas práticas artísticas, de desnaturalização das mídias locativas, tanto das normatividades que as cercam, quanto dos modos de percepção que modulam. 
CAPITULO 3- PRÁTICAS CONTRACARTOGRÁFICAS NA ARTE 


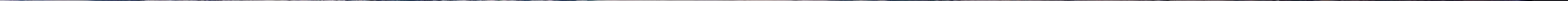




\section{Considerações Finais}


Os objetivos que construíram o eixo desta pesquisa foram os de buscar entender como no contexto contemporâneo, em que há uma saturação informacional e um convívio hipermediado por tecnologias geolocativas, o homem se localiza diante de sua esfera física, política, econômica, cultural, dentre tantos outros âmbitos que compõem seu posicionamento social.

Nesse sentido, para ampliar uma leitura crítica do contexto surge uma segunda questão a complementar este eixo. Entender como, em tempos de profusão de mapas digitais, mapas colaborativos e dados georreferenciados, formas de visibilidade e invisibilidade são produzidos, além de estudar práticas que se ocupam em tensionar esses aspectos e como o fazem.

Para percorrer essas indagações, foi importante, primeiramente, compreender como se desenvolveu a representação da localização e notar como as maneiras de representar 'onde se está' possuem fortes ligações com o entendimento que o homem tem do mundo. Sempre existiram duas maneiras de representar a localização, por meio da inserção do sujeito nesta representação e deixar claro que é uma percepção sua, locativa. A outra, distanciada, que procura se abster dessa representação e apresentar a informação como algo autônomo e isento.

Independentemente de qual maneira o fizesse, reconhecer 'onde se está' passa a ser um sinal de poder, domínio e territorialidade, no conto "Os Dois Reis e os Dois Labirintos" de Jorge Luis Borges: um dos reis por um ato de vingança submete o outro ao pior dos labirintos, o deserto. Para o personagem perdido, que não tinha qualquer conhecimento que o permitia articular e reconhecer referências do deserto, resultou numa perda tal, que o sucumbiu à própria morte. Ser submetido a uma caminhada sem qualquer trajetória conhecida o expôs de maneira fatal a adversidades naturais do deserto.

Historicamente, a relação entre homem e espaço sofre sensíveis transformações. Apesar de hoje essa relação possuir apreensões completamente outras, durante os desenvolvimentos 
cartográficos de aperfeiçoamento dos mapas para torná-los mais objetivos, neutros e precisos, mais se instaurava a 'aura' de verdade e neutralidade na cartografia. No entanto, o que simultaneamente ocorria, nessa busca de precisão dos mapas, era que essas representações eram associadas a demarcações ideológicas e de poder.

No entanto, os embates científicos não se configuram somente como discussões acerca das projeções matemáticas que estão presentes. Como acerca dos avanços tecnológicos na área não conta apenas a disponibilização de novos meios. Há uma dimensão de visibilidade e invisibilidade presente nessas interpretações. Indagações e pontos de vistas e interesses diversos trazem à tona as parcialidades, entrelinhas, omissões e agendas que na realidade essas representações possuem. São em discussões entre geógrafos que essas fragilidades dos mapas passam a ser compreendidas detalhadamente e, por fim, reinterpretadas e criticadas. Passa-se a se entender o real poder de quem afirma (e como afirma) 'você está aqui'.

Mesmo hoje, em um contexto hipermapeado e mediado por mídias locativas, deixa-se por conta dos satélites e sua precisão atômica e 'isenta', que nos digam como representar o globo terrestre num plano, numa tela. No entanto, as fragilidades e a personalidade tendenciosa dos mapas persistem, de uma forma mais velada do que nunca, pois atribui-se muito das autorias informacionais a sistemas e máquinas. Os interesses e intenções das grandes empresas, governamentais e militares, parecem passar desapercebidos nessas mediações tecnológicas.

Em meios a tantos serviços, conteúdos, entretenimento e relacionamentos oferecidos na palma da mão, desapercebe-se o volume de troca informacional que se realiza nesses aplicativos, e pouco se questiona sobre o que realmente se alimenta com o seu conteúdo pessoal e o quão significativos se tornam quando utilizados cotidianamente por milhões de pessoas para deslocar-se de modo eficiente em uma cidade, encontrar serviços de toda espécie, registrar performances esportivas, dentre tantas outras atividades rotineiras. Há claramente uma concentração de poder sobre a coleta e o processamento de informações em escala planetária, que parece caminhar para a capacidade de controle sobre a vida.

São, portanto, cada vez mais necessárias as lentes críticas dos cartógrafos teóricos e praticantes 
que questionam a parcialidade da objetividade dos mapas, pelas quais é possível manter a compreensão de como essas representações podem ser propositivas e ativas na maneira de lidar e compreender o mundo, além, é claro, de desnaturalizar limites e fronteiras.

Neste trabalho foram destacadas duas interessantes aproximações críticas a esse universo. A primeira, com grupos e organizações ativistas que se utilizam de recursos tecnológicos locativos para visibilizar e atentar para informações que não costumam ser vinculadas em mapas colaborativos dominantes. Utilizando-se da linguagem fácil e intuitiva que estes mapas colaborativos já possuem, pretendem o amplo alcance e a viabilização de baixo custo para reivindicar, protestar e divulgar suas lutas e inquietações.

Ainda que se utilizem das tecnologias locativas para visibilizar o que normalmente é invisibilizado, esse grupo não extrapola sua contestação para repensar essas hiper-mediações e representações hegemônicas e dominantes. Suas ações online, apesar de adquirirem um alcance significativo, conseguem responder a algum contexto socio-político em tensão, adotando ênfases distintas diante de um mesmo contexto, como os casos de Arriving in Berlim e iStreetWatch.

A outra aproximação, por meio das práticas artísticas, que há tempos indaga e reflete sobre a desconstrução de mapas e representações espaciais, vem recebendo o olhar atento de geógrafos, os quais parecem ver na arte outras propostas para as cartografias. Reconhecem que o artista não rejeita a cartografia, mas tem plena ciência e enfrenta os poderes que estão naturalizados nela (cartografia).

Foi aprofundando em quatro projetos que foi possível observar, com maior clareza, como o campo da arte repensa e subverte questões tidas como pasteurizadas e investiga outras formas de visualização e espacialização de certos conceitos, como, por exemplo, localização e trajetória. Mostram como a tecnologia, por maior precisão que possa prometer, está embasada em abstrações, convenções, (in) visibilidades e relações de poder criadas e aceitas.

Refletir e pensar sobre como o homem se localiza hoje nas várias esferas sociais nos diz 
muito sobre o contexto contemporâneo, como as cidades lidam com e contribuem para essa pervasividade informacional. Ainda que exista, essa saturação informacional ainda é concentrada e detida nas mãos de poucos.

Nesse contexto, as contracartografias passam a assumir um papel importante e vem garantir que os mapas não se tornem armadilhas. Permitem que o poder ainda possa ser desafiado e que qualquer informação ainda possa ser visibilizada. Ainda que a cartografia tenha alcançado um limite de atuação e representação, é com as práticas contracartográficas que uma mudança epistemológica pode ser pensada e ativada. Grupos que já possuem a tradição de enfrentar sistemas, como os ativistas e artistas, vêm abrindo diferentes perspectivas. Esse parece ser o papel irrefutável e cada vez mais necessário dos contracartógrafos.

Esta pesquisa se demonstrou bastante reveladora e permitiu que uma série de frentes interessantes fossem abertas, pois, além de tratar de um contexto recente, e, portanto, pouco explorado, lidou com áreas distintas de conhecimentos que se desdobram em diversos eixos e articulações.

O que particularmente me despertou o interesse para um aprofundamento futuro foi, ainda neste contexto de hipermapeamentos, refletir sobre quanto os sistemas de mapeamentos digitais colaborativos são determinantes para a compreensão de uma cidade. Em outras palavras, como representações e sistemas de localização e consumo informacional utilizados em larga escala, limitam ou conseguem diferenciar a percepção urbana. A compreensão sobre como esses mecanismos atuam parece ser uma chave relevante para o entendimento de como as cidades vêm sendo pensadas e utilizadas. 


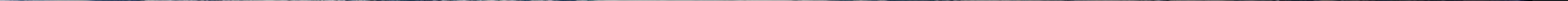




\section{Bibliografia de referência}


ABAD, A; OLIVA, D. Canal Motoboy. 2016. Disponível em:<https://revistazum.com.br/ revista-zum-10/canal-motoboy/ >. Acesso em: 03 jan. 2018.

ABRAHAMS, J; HALL, P. Else/Where: mapping new cartographies of networks territories. Minessota: University of Minessota Press, 2006.

ABRAHAMS, J.; HALL, P.; WOOD, J. Skywriting. In ABRAHAMS, J.; HALL, P. Else/ Where: mapping new cartographies of networks territories. Minessota: University of Minessota Press, 2006.

ALŸS, F. Press release para exposição: Sometimes doing Poetic Can Become Political, and Sometimes Doing Something Political Can Become Poetic. David Zwirner Gallery, New York, 2007.

BAUDRILLARD, J. Simulacros e simulações. Lisboa: Relógio D’água, 1991.

BORGES, J. L. O Aleph. Rio de Janeiro: Editora Globo, 1982.

Do Rigor na Ciência. Obras Completas, vol. II. Editora Globo, 1975.

BOSSI, A. Fenomenologia do Olhar. In: NOVAES, A (org). O Olhar, São Paulo: Companhia Das Letras, 1993.

CALISTO, B; MASTRIGT, J. V. Fórum Juventudes apresenta resultados do aplicativo "Nós por Nós" que denuncia violência policial. Rio on Watch, Rio de Janeiro, 23 de abril de 2016. Disponível em:<http://rioonwatch.org.br/?p=19266 . Acesso em: 1 set. 2017.

CAPELAS, B.; RIBEIRO, B.; MENGUE, P. Com lentidão triplicada, São Paulo tem segunda-feira atípica. Estadão, São Paulo, 23 out. 2017. Disponível em: $<$ http://sao-paulo. estadao.com.br/noticias/geral,com-lentidao-triplicada-sao-paulo-tem-segunda-feiraatipica,70002057753 >. Acesso em: 10 fev. 2018.

CARERI, F. Walkscapes - O Caminhar como Prática Estética. São Paulo: Editora G. Gili, 2013.

CARROLL, L. The Hunting of the Snark and Other Poems and Verses. New York: Harper, 1903. 
CARVALHO, B. Caminhar na cidade - experiência nos caminhares de Richard Long e Francis Alÿs; depoimentos de uma pesquisa poética. 2007, 247f. Dissertação de Mestrado - Faculdade de Arquitetura e Urbanismo, Universidade de São Paulo, São Paulo, 2007.

CHAUÍ. M. Janela da Alma, Espelho do Mundo. In: NOVAES, Adauto (org). O Olhar, São Paulo: Companhia Das Letras, 1993.

COSGROVE, D. Mappings. Reaktion Books Ltd, 1999.

. Apollo’s Eye. Maryland: The John Hopkins University Press, 2001.

COStalima, M. Projeto Correspondência. São Paulo: Pingado-prés, 2015.

CRAMPTON, J; KRYGIER, J. An Introduction to Critical Cartography. An International E-Journal for Critical Geographies, V.4, n1, p.11-33, 2006. Disponível em: $<$ http://ojs. unbc.ca/index.php/acme/index>. Acesso em: Mar.2015.

CRAMPTON, J. W. Mapping- A Critical Introduction to Cartography and GIS. West Sussex: Wiley-Blackwell Publishing, 2010.

CRISCUOLO, L; PEPE, M; SEPPI, R; BORDOGNA, G, CARRARA, P; ZUCCA, F. Alpine Glaciology: An Historical Collaboration between Volunteers and scientist and the Challenge Presneted by an Ittegrated Approach. ISPRS International Journal of GeoInformation, v.2, p.680-703, Oct.2013. Editorial. Disponível em: < http://www.mdpi. com/2220-9964/2/3/680> Acesso em: set. 2017.

DODGE, M; KITCHIN, R; PERKINS, C. Thinking about maps. In: DODGE, M; KITCHIN, R; PERKINS, C (Ed). Rethinking Maps. New York: Routledge Studies in Human Geography, 2009.

FARMAN, J. Mapping the digital empire: Google Earth and the process of postmodern cartography. Sage Journals- New Media \& Society - vol.12, n.6, p.869-888, 2010.

Routledge, 2012.

; Mobile Interface Theory - Embodied Space and locative Media. New York:

FOUCAULT, M. So Is It Important to Think? In FAUBION, J.D. Power- essential works of Foucault 1954-1984. London: Penguin Books, 2000. 
. Segurança, Território, População: Curso dad no Collège de France (1977-1978). São Paulo: Martins Fontes, 2008.

FREITAS, A. Por que os pontos de interesse de Pokémon Go são distribuídos de maneira desigual na cidade. Nexo jornal, 10 ago. 2016. Disponível em: $<$ https://www.nexojornal. com.br/expresso/2016/08/10/Por-que-os-pontos-de-interesse-de-Pokémon-Go-sãodistribu\%C3\%ADdos-de-maneira-desigual-na-cidade >. Acesso em: 10 fev. 2018.

GARTNER, G. Web mapping 2.0. In: DODGE, M; KITCHIN, R; PERKINS, C (Ed). Rethinking Maps. New York: Routledge Studies in Human Geography, 2009.

GENTTLEMAN, J. Death toll in Kenya exceeds 1000, but talks reach crucial phase. The New York Times, New York, 6 fev. 2008. Disponível em: <http://www.nytimes.com/2008/02/06/ world/africa/06kenya.html>. Acesso em: 10 ago. 2017.

HARLEY, J. B.; WOODWARD, D. (Ed.). The History of Cartography - vol.1 Cartography in Prehistoric, Ancient, and Medieval Europe and the Mediterranean. Chicago: University of Chicago Press, 1987. V1.

HARLEY, J. B. Text and Contexts in the interpretation of Early Maps. LAXTON, Paul. (Ed.).The New Nature of Maps. Baltimore: The Johns Hopkins University Press, 2001.P.3350.

. Deconstructing the Map. LAXTON, Paul.(Ed.).The New Nature of Maps. Baltimore: The Johns Hopkins University Press, 2001.P.149-168.

HOLMES, B. Drifting Through the Grid: Psychogeography and Imperial Infrastructure. In. Stephen Wright (Ed). Dataesthetics Reader: How to Do Things with Data. Zagreb: Grafički zavod Hrvatske, 2006.

. Counter Cartographies. In. ABRAHAMS, Janet; HALL, Peter. EIse/Where: mapping new cartographies of networks territories. Minessota: University of Minessota Press, 2006.

JACOB, C. Mapping in the Mind: The Earth from Ancient Alexandria. In COSGROVE, Denis. Mappings. London: Reaktion Books Ltd, 1999. P. 24-49. 
KALlET, T. Homo Cartographicus. In: KALlET, T. (Ed). Few Adults Crawl: Thoughts on Young Children Learning. Grand Forks: Center for Teaching and Learning/University of North Dakota, 1995.

KITCHIN, R; DODGE, M. 'Rethinking maps', Progress in Human Geography, 31(3): 331-44, 2007.

KRYGIER, J; WOOD, D. Ce n'est pas le monde In: DODGE, Martin; KITCHIN, Rob; PERKINS, Chris (Ed). Rethinking Maps. New York: Routledge Studies in Human Geography, 2009.

KURGAN, L. Close Up at a Distance: Mapping, Technology, and Politics. New York: Zone Books, 2013.

LATOUR, B. Science in Action. Cambridge-MA: Harvard University Press, 1987.

LAURIAULT, T. GPS Tracing - Personal Cartographies. The Cartographic Journal-Art \& Cartography Special Issue, v. 46, n 4, p360-365, nov 2009.

LEMOS, A. Mídia Locativa e territórios Informacionais. In ARANTES, Priscila e SANTAELLA, Lúcia. Estéticas Tecnológicas”, São Paulo: Editora PUC-SP, 2007.

MARICONDA, P R. Galileu e a Ciência Moderna. Cadernos de Ciências Humanas. V.9, n.16, jul./dez., 2006,p.267-292.

MONMONIER, Mark. How to Lie with Maps. Chicago: University of Chicago Press, 1991.

NOVEMBER, V; HÜBNER, E; LATOUR, B. Entering a risky territory: space in the age of digital navigation. Environment and Planning D: Society and Space - vol. 28, p. 581$599,2010$.

O'ROURKE, K. Walking and Mapping: Artists as Cartographers. Cambridge: The MIT Press, 2003.

PARASKEVOPOULOU, O; CHARITOS, D; RIZOUPOULOS, C. Location-specific art prectices that challenge the traditional conception of mapping. Art Nodes- E-Journal on art, Science and technology, Issue 8, p1-11, dez. 2008.

PICKLES, J. A History of Spaces- Cartographic reason, mapping and the geo-coded 
world. New York: Routledge, 2004.

Representations in an Electronic Age: Geography, GIS, and Democracy. Praxis (e) Press, 2008. Disponível em: $<$ https://atrium.lib.uoguelph.ca:8443/xmlui/bitstream/ handle/10214/1827/33-Pickles.pdf?sequence=1\&isAllowed=y >. Acesso em 10 fev. 2018.

RIBEIRO, J. C.; LIMA, L. Mapas colaborativos digitais e (novas) representações sociais do território: uma relação possível. Ciberlegenda, Rio de Janeiro, v.2, n.25, p.38-47, 2011. Disponível em: <http://www.ciberlegenda.uff.br/index.php/revista/article/view/469 . Acesso em: 10 set. 2017.

RIDER, A. The "Curve over the Cresto f the Hill":Carl Andre and Richard Long. In PEABODY, R. (Ed.) Anglo-American Exchange in Postwar Sculpture, 1945-1975. Los Angeles: Getty Publications, 2011.

RUSSELL, B. TCM Online Reader Introduction.2006. Disponível em: $<$ http://web.archive. org/web/20060720212044/http://locative.net/tcmreader/index.php?intro;russell >. Acesso em: 30 abr. 2017.

SANT, A. Redefining The Basemap. intelligent agente, vol.6, n.2, 2006. Disponível em: $<$ http://www.intelligentagent.com/archive/Vol6_No2_interactive_city_sant.htm $>$ Acesso em: 10 ago. 2017.

SANTIAGO, A. Towards a new Datascape. In XX Congresso de la Sociedad Iberoamericana de Gráfica Digital -SIGRADI, 2016, Buenos Aires. Anais, Argentina, 2016.p.792-797.

SANTOS, E. M. (Coord). Coletivo canal*MOTOBOY- O nascimento de uma categoria. Rio de Janeiro: Aeroplano editora, 2009.

SCAFFI, A. Mapping Eden: Cartographies of the Earthly Paradise. In COSGROVE, Denis. Mappings. London: Reaktion Books Ltd, 1999. P.50-70.

SEE, L; FRITZ, S.; LEEUW, J. The Rise of Collaborative Mapping:Trends and Future Directions. ISPRS International Journal of Geo-Information, v.2, p.955-958, Oct.2013. Editorial. Disponível em: < http://www.mdpi.com/2220-9964/2/4/955> Acesso em: 10 set. 2017. 
SEEMANN, J. Mercator e os Geógrafos: Em busca de uma "Projeção" do mundo. Revista de Geografia da UFC. Ano 02, n.3, p.7-18. 2003.

- Tradições Humanistas na Cartografia e a Poética dos Mapas. Qual espaço do Lugar. p.69-92, 2012

SMITH, C. D. Prehistoric Maps and the History of Cartography: An Introduction. In HARLEY, J.B.; WOODWARD, D. (Ed.). The History of Cartography - vol.1 Cartography in Prehistoric, Ancient, and Medieval Europe and the Mediterranean. Chicago: University of Chicago Press, 1987. V1. P.45-49

. Cartography in the Prehistoric Period in the Old Wolrd: Europe, the Middle East, and North Africa. In HARLEY, J.B.; WOODWARD, D. (Ed.). The History of Cartography - vol.1 Cartography in Prehistoric, Ancient, and Medieval Europe and the Mediterranean. Chicago: University of Chicago Press, 1987. V1. P.54-101.

SNYDER, John P. Map Projections in the Renaissance in. WOODWARD, D. (Ed). The History of Cartography - vol.3 Cartography in the European Renaissance Part 1. Chicago: University of Chicago Press, 2007. V3. P 365-381.

- Map Projections-AWorking Manual. Washington: United States Government Printing Office, 1987.

TALLY, R. Spatiality. New York: Routledge, 2013.

TUAN, Y. Space and Place. The Perspective of Experience. Minneapolis: University of Minnesota Press, 2003.

TUTERS, M. VARNELIS, K. Beyond Locative Media. In Networked Publicsblog.[http:// www.Networkedpublics.org/locative_media/beyond_locative_media, 2006. Acesso em: 01 ago. 2014.

USHAHIDI. Ushahidi.com. Kenya Pundit, Kenya, 9 de janeiro. 2008. Disponível em: $<$ http:// www.kenyanpundit.com/2008/01/09/ushahidicom/ >. Acesso em: 10 ago. 2017

WATSON, R. Art at the interface of data and image. 2013. Disponível em: $<$ http://www. metamute.org/editorial/articles/art-interface-data-and-image $\geq$. Acesso em: 10 nov. 2017. 
WOOD, D. Map Art. Cartographic Perspective: Journal of the North American Cartographic Information Society. N.53, Winter 2006, p.5-14.

Rethinking The Power of Maps. New York: The Guilford Press, 2010.

WOOD, J. Can't be elsewhere when GPS drawing. In ABRAHAMS, J.; HALL, P. Else/ Where: mapping new cartographies of networks territories. Minessota: University of Minessota Press, 2006.

.[Synapse elist]moving the lawn.2008. Disponível em: $<$ http://lists.synapse.net.au/pipermail/elist/2008-July/000136.html $>$. Acesso em: 1 jun. 2015.

WOOD, J. Meridians. Disponível em:< http://www.gpsdrawing.com/gallery/land/meridians. html>. Acesso em: 10 fev. 2018.

WOOD, P.; FRANSCINA, F.; HARRIS, J.; HARRISON, C. Modernismo em Disputa A arte desde os anos quarenta. São Paulo: Cosac \& Naify, 1998.

WOODWARD, D. Cartography and the Renaissance: Continuity and Change. In WOODWARD, D. (Ed). The History of Cartography - vol.3 Cartography in the European Renaissance Part 1. Chicago: University of Chicago Press, 2007. V3. P 3-24.

\section{SITES:}

AIRBNB. Disponível em:< https://www.airbnb.com.br>. Acesso em: 3 jan. 2018.

ARRIVING IN BERLIN. Disponível em: $<$ https://arriving-in-berlin.de>. Acesso em: 3 jan. 2018.

CHEGA DE FIU FIU. Disponível em: $<$ http://chegadefiufiu.com.br $>$. Acesso em: 3 jan. 2018.

DWARSHUIS. Disponível em: $<$ https://www.dwarshuis.com/various/airbnb/amsterdam/>. Acesso em: 3 jan. 2018.

GPS DRAWING. Disponível em: $<$ http://www.gpsdrawing.com/gallery/land/meridians. html/>. Acesso em: 3 jan. 2018. 
iHOLLABACK. Disponível em:< https://www.ihollaback.org >. Acesso em: 3 jan. 2018.

INSTAGRAM. Disponível em:< https://www.instagram.com>. Acesso em: 3 jan. 2018.

iSTREET WATCH. Disponível em: $<$ https://www.istreetwatch.co.uk $>$. Acesso em: 3 jan. 2018.

ON BROADWAY. Disponível em: < http://on-broadway.nyc >. Acesso em: 10 fev. 2018.

ONDE FUI ROUBADO. Disponível em: < http://www.ondefuiroubado.com.br >. Acesso em: 10 fev. 2018.

OPENS STREET MAP. Disponível em: $<$ https://www.openstreetmap.org $>$. Acesso em: 10 fev. 2018.

POKEMON GO. Disponível em: $<$ https://www.pokemongo.com/pt-pt/ >. Acesso em: 10 fev. 2018.

MEGAFONE. Disponível em: <http://megafone.net/saopaulo/about> Acesso em: 3 jan. 2018.

NATURAL EARTH. Disponível em: < http://www.naturalearthdata.com/blog/natural-earthversion-1-3-release-notes/> ._Acesso em: 31 jan. 2011.

NÓS POR NÓS. Disponívelem: $<$ https://play.google.com/store/apps/details?id=appinventor. ai_arquivopedrada.AppNosPorNos>. Acesso em: 10 fev. 2018.

STRAVA. Disponível em:<https://www.strava.com >. Acesso em: 10 fev. 2018.

USHAHIDI. Disponível em:< https://www.ushahidi.com>. Acesso em: 10 fev. 2018.

WAZE. Disponível em:< https://www.waze.com>. Acesso em: 3 jan. 2018.

WE ARE DATA. Disponível em:< http://wearedata.watchdogs.com>. Acesso em: 3 jan. 2018.

WIKICRIMES. Disponível em: $<$ http://www.wikicrimes.org>. Acesso em: 3 jan. 2018. 